\author{
UNIVERSIDADE DE SÃO PAULO \\ ESCOLA DE ARTES, CIÊNCIAS E HUMANIDADES \\ PROGRAMA DE PÓS-GRADUAÇÃO EM SUSTENTABILIDADE
}

RAFAELA AGUILAR SANSÃO

\title{
As práticas de governança e gestão para a mitigação de pressões e ameaças em unidades de conservação urbanas
}



RAFAELA AGUILAR SANSÃO

\section{As práticas de governança e gestão para a mitigação de pressões e ameaças em unidades de conservação urbanas}

Dissertação apresentada à Escola de Artes, Ciências e Humanidades da Universidade de São Paulo para obtenção do título de Mestre em Ciências pelo Programa de Pós-Graduação em Sustentabilidade.

Versão corrigida contendo as alterações solicitadas pela comissão julgadora em 20 de março de 2017. A versão original encontra-se em acervo reservado na Biblioteca da EACH/USP e na Biblioteca Digital de Teses e Dissertações da USP (BDTD), de acordo com a Resolução CoPGr 6018, de 13 de outubro de 2011.

Área de Concentração: Ciência, Tecnologia e Gestão para a Sustentabilidade.

Orientador:

Prof. Dr. Marcelo Pereira de Souza

São Paulo 
Autorizo a reprodução e divulgação total ou parcial deste trabalho, por qualquer meio convencional ou eletrônico, para fins de estudo e pesquisa, desde que citada a fonte.

Sansão, Rafaela Aguilar

As práticas de governança e gestão para a mitigação de pressões e ameaças em unidades de conservação urbanas / Rafaela Aguilar Sansão ; orientador, Marcelo Pereira de Souza. São Paulo, 2017

272 p. : il

Dissertação (Mestrado em Ciências) - Programa de PósGraduação em Sustentabilidade, Escola de Artes, Ciências e Humanidades, Universidade de São Paulo Versão corrigida

1. Proteção ambiental. 2. Áreas de conservação. 3.

Gestão ambiental. I. Souza, Marcelo Pereira de, orient. II. Título 
Nome: SANSÃO, Rafaela Aguilar

Título: As práticas de governança e gestão para a mitigação de pressões e ameaças em unidades de conservação urbanas

Dissertação apresentada à Escola de Artes, Ciências e Humanidades da Universidade de São Paulo para obtenção do título de Mestre em Ciências pelo Programa de Pós-Graduação em Sustentabilidade.

Área de concentração: Ciência, Tecnologia e Gestão para a Sustentabilidade.

Aprovada em: 20/03/2017

\section{Banca Examinadora}

Prof. Dr. Evandro Mateus Moretto

Universidade de São Paulo. Escola de Artes, Ciências e Humanidades

Profa. Dr. Victor Eduardo Lima Ranieri

Universidade de São Paulo. Escola de Engenharia de São Carlos

Prof. Dra. Angela Pellin

Instituto de Pesquisas Ecológicas 

Dedico este trabalho a todos os profissionais das unidades de conservação urbanas. 



\section{AGRADECIMENTOS}

À Fundação de Amparo à Pesquisa do Estado de São Paulo - FAPESP, pela concessão da bolsa de mestrado, possibilitando assim o desenvolvimento desse estudo.

Ao Prof. Dr. Marcelo Pereira de Souza, por ter me acolhido na Casa 39, incentivado a trilhar no caminho acadêmico e por todas as orientações e sugestões valiosas! Agradeço também pelas inúmeras prosas, cafés deliciosos e palavras de apoio durante todos esses anos!

A todos os gestores e funcionários das unidades de conservação urbanas, em especial ao Gustavo Lopes, Vladimir Arrais, Guilherme Sandoval, Giselda Durigan, Susanne Glatz-Jorde, Regine Hradetzky, Patrick Huvenne e Marieke Kuipers. Obrigada por gentilmente aceitarem participar deste estudo e pelas sugestões, foram essenciais para que esta pesquisa fosse possível de ser realizada.

Ao amigo Miguel von Behr, obrigada pelos ensinamentos no curso e pelas inúmeras contribuições feitas durante todos esses anos de trabalho em prol das unidades de conservação urbanas do país.

Aos professores que participaram do meu exame de qualificação, Victor Ranieri, Evandro Moretto e Alexandre Igari! Muito obrigada pela leitura crítica e por todas as contribuições!

Aos professores Michael Jungmeier e Heike Egner, por terem me recebido e proporcionado a oportunidade única de viver e estudar em outro país. E, principalmente, muito obrigada pela parceria e recomendações para a qualidade desta pesquisa!

A toda a minha família, em especial à minha mãe, Clarice, por ser esse exemplo de mulher, que um dia eu espero ser! Por sempre me apoiar em todas as minhas escolhas! Ao meu pai, Tadeu, por ser meu amigo e por sempre tentar me entender (por mais dificil que às vezes possa ser), obrigada por absolutamente tudo! À minha irmã, Juliana, pela cumplicidade, amizade e pelo amor incondicional! Não existem palavras para descrever o que vocês todos representam para mim!

Ao meu amor, Lucas! Muito obrigada por tudo, por sempre acreditar em mim! Obrigada pelos incontáveis incentivos, sugestões e críticas que tornaram possível a execução deste trabalho! Por escolher estar ao meu lado nos momentos mais difíceis e felizes desta caminhada, sem você nada disso faria sentido!

Aos meus amigos do mestrado que fiz em São Paulo! Obrigada em especial à minha querida amiga Laura (Pamonha), por termos vivenciados todos os momentos alegres e também os mais 
frustrantes juntas! Sem você a vida acadêmica não teria sido a mesma! Obrigada também ao Gui, amigo e parceiro de sala, pelas prosas, risadas e conselhos!

A todos os amigos que fiz na Casa 39! Muito obrigada pela agradável convivência e aprendizado, especialmente à Aline e ao Aurélio, pela sempre disponibilidade, paciência em me ensinar e pelas sugestões valiosas durante esse trabalho.

Aos amigos que fiz em Ribeirão Preto e que levarei para sempre comigo! Muito obrigada por fazerem parte dos melhores momentos da minha vida! Obrigada em especial ao meu amigo Tomate, pela amizade e pelas inúmeras ajudas que tornaram possível a minha ida à Áustria.

A todos os meus amigos de Sorocaba, em especial, Moira, Aline, Tham, Fabi, Ana, Sarah, Gute e João! Obrigada pelas experiências memoráveis durante todas essas décadas de amizade sincera e por compreenderem a minha ausência nesses últimos anos!

Ao meu amigo Guilherme (Biscoito), por ser essa pessoa maravilhosa, por sempre me fazer bem e por nossa amizade nunca ter mudado, apesar da distância.

Aos queridos amigos que a vida me deu, Adriana, Carol, Vitor e Ziza! Obrigada por terem me acolhido na família de vocês!

À todas as pessoas que contribuíram de alguma forma para que fosse possível a realização deste trabalho, meus sinceros agradecimentos! 
“A criação de uma área protegida é uma confissão de suicídio. Uma sociedade que precisa proteger a natureza de si mesma não pode estar certa."

José Lutzemberger 



\section{RESUMO}

SANSÃO, Rafaela Aguilar. As práticas de governança e gestão para a mitigação de pressões e ameaças em unidades de conservação urbanas. 2017. 272p. Dissertação (Mestrado em Sustentabilidade) - Escola de Artes, Ciências e Humanidades, Universidade de São Paulo, São Paulo, 2017. Versão corrigida.

As Unidades de Conservação (UCs) urbanas vêm sendo pressionadas e ameaçadas por atividades antrópicas, resultando em novos desafios de gestão e governança. Desse modo, buscou-se analisar os procedimentos utilizados para mitigação das principais pressões e ameaças em UCs urbanas e identificar as principais variáveis que interferem no alcance dos seus objetivos. Para tanto, foram realizadas entrevistas semiestruturadas com as equipes de gestão de UCs urbanas nacionais (Parques Estaduais do Jaraguá e Cantareira, Estações Ecológicas de Ribeirão Preto e Assis) e internacionais (Sítios Natura 2000 Lendspitz-Maiernigg, Sonian Forest e Parque Nacional Zuid-Kennemerland), onde foram avaliadas as principais pressões e ameaças enfrentadas por essas áreas, bem como as ações de conservação que vem sendo adotadas. As entrevistas foram direcionadas por questões adaptadas da Metodologia RAPPAM (Rapid Assessment and Prioritization of Protected Area Management) e para a análise dos dados foi utilizada a técnica Análise de Conteúdo. Além das entrevistas, foram analisadas as orientações e melhores práticas propostas pela IUCN (União Internacional para a Conservação da Natureza), instituição reconhecida internacionalmente por propor recomendações relevantes para áreas protegidas mundiais. Os resultados indicam uma série de pressões e ameaças comuns aos sete casos de estudos (e.g. desenvolvimento urbano do entorno; estradas e rodovias), bem como pressões e ameaças que ocorrem somente nos casos de estudos nacionais (e.g. incêndios florestais e ocupações ilegais;) e internacionais (transmissão de doenças entre animais silvestres). Também observou-se que todas as equipes de gestão buscaram implementar procedimentos para mitigação em seus territórios, tais como ações de: proteção (e.g. fiscalização e monitoramento); manejo (e.g. controle de espécies exóticas invasoras); operacionalização (e.g. articulação com diferentes instituições); integração (e.g. sensibilização ambiental); uso público (e.g. atividades turísticas de baixo impacto ambiental); e conhecimento (e.g. promoção de pesquisas científicas). As principais variáveis que prejudicam o cumprimento dos seus objetivos são: recursos humanos e financeiros insuficientes, baixa transparência e participação social nos processos de tomada de decisão. Observa-se que a IUCN propõem cinco princípios para uma boa governança (i.e. legitimidade e voz; direção; desempenho; responsabilidade e equidade e direitos) e diversas práticas para uma gestão adequada (e.g. promover uma gestão dinâmica, ativa e planejada, seguindo concepções racionais, adaptativas e participativas). Desse modo, conclui-se que os responsáveis pelas UCs urbanas devem promover o empoderamento dos conselhos, para que estes funcionem adequadamente como fóruns de discussão e participação, bem como devem integrar essas áreas com seus territórios, através de legislações e diretrizes específicas. A adoção de práticas de governança e gestão adequadas, exequíveis, dinâmicas e participativas em UCs urbanas, são fundamentais para a manutenção de ecossistemas saudáveis, os quais formam a espinha dorsal de um futuro mais sustentável. Além disso, para o cumprimento das propostas discutidas, entende-se como imprescindível que as autoridades governamentais incorporem em suas legislações a definição de UCs urbanas, reconhecendo a sua importância e garantindo com que estas áreas recebam maiores atenções.

Palavras-chave: unidades de conservação urbanas; pressões; ameaças; ações de conservação; gestão de unidades de conservação urbanas; governança em unidades de conservação urbanas. 



\begin{abstract}
SANSÃO, Rafaela Aguilar. Governance and management practices for mitigating pressures and threats in urban protected areas. 2017. 272p. Dissertation (Master of Science) - School of Arts, Sciences and Humanities, University of São Paulo, São Paulo, 2017. Corrected version.

Urban protected areas (PAs) have been under pressure and threatened by anthropic activities, resulting in new management and governance challenges. Thus, we aimed to analyze the procedures used to mitigate the main pressures and threats in urban PAs and to identify the main variables that interfere with the achievement of their objectives. Therefore, we did semi-structured interviews with the management staff of national (State Parks Jaraguá and Cantareira and Ecological Stations of Ribeirão Preto and Assis) and international urban PAs (Natura 2000 Sites Lendspitz-Maiernigg, Sonian Forest and National Park Zuid-Kennemerland). We evaluated, together with their staff, the main pressures and threats faced by the PAs, as well as we analyzed the conservation actions they adopted. The interviews were directed by questions adapted from the Rapid Assessment and Prioritization of Protected Area Management (RAPPAM) Methodology, and to analyze the data we used the Content Analysis technique. In addition to the interviews, we analyzed the guidelines for best practices proposed by the IUCN (International Union for Conservation of Nature), an internationally recognized institution for proposing relevant recommendations to global protected areas. The results indicate a series of pressures and threats common to the seven PAs (e.g. urban development and establishment of roads and highways), as well as pressures and threats found only in the national PAs (e.g. forest fires and illegal occupations) and in the international PAs (e.g. transmission of diseases between wild animals). It was also noted that all case studies adopted six types of conservation actions, such as: protection (e.g. surveillance and monitoring); management (e.g. control of invasive alien species); operationalization (e.g. articulation with different institutions); integration (e.g. environmental awareness); public use (e.g. promotion of tourism and recreational activities of low environmental impact); and knowledge (e.g. promotion of scientific research). The main variables that undermine the fulfillment of urban PAs objectives are insufficient human and financial resources, low transparency and social participation in decision-making processes. We observed that IUCN proposes five principles for good governance (i.e. legitimacy and voice, direction, performance, accountability, equity and rights) and various practices for appropriate management (e.g. promote a dynamic, active and planned management, following rational, adaptive and participative conceptions). Thus, we concluded that those responsible for urban PAs should promote the empowerment of their councils, so that they function properly as discussion forums, as well as must integrate these areas with their territories, through specific legislation. The adoption of appropriate, feasible, dynamic and participatory governance and management practices in urban PAs are fundamental to the maintenance of healthy ecosystems, which form the backbone of a more sustainable future. In addition, to achieve the proposals discussed, it is essential that government authorities incorporate into their legislation the definition of urban PAs, recognizing their importance and ensuring that these areas receive greater attention.
\end{abstract}

Keywords: urban protected areas; pressures; threats; conservation actions; management of urban protected areas; governance in urban protected areas. 



\section{LISTA DE FIGURAS}

Figura 1. Porcentagem de áreas terrestres e marinhas protegidas.

Figura 2. Representação esquemática de Espaços Territoriais Especialmente Protegidos (ETEPs), Áreas Protegidas (APs) e Unidades de Conservação (UCs)....................................................... 45

Figura 3. Modelos de gestão estatais aplicáveis às UCs. .......................................................... 47

Figura 4. Modelos de gestão não estatais aplicáveis às UCs............................................................. 48

Figura 5. Exemplo da classificação de ameaças proposta por Salafsky et al. (2008), dividida em três níveis hierárquicos. 56

Figura 6. Delimitação do recorte da pesquisa, a partir de cinco critérios para seleção dos casos de estudos nacionais.

Figura 7. Imagem de satélite do Parque Estadual do Jaraguá (PEJ), delineado pela cor laranja. 76

Figura 8. Zona de Amortecimento do Parque Estadual do Jaraguá (PEJ)..................................... 78

Figura 9. Zoneamento interno do Parque Estadual do Jaraguá (PEJ). .......................................... 79

Figura 10. Principais pressões e ameaças do Parque Estadual do Jaraguá (PEJ)........................... 80

Figura 11. Imagem de satélite do Parque Estadual da Cantareira, delineado pela cor laranja..... 87

Figura 12. Zoneamento interno do Parque Estadual da Cantareira (PEC) ................................... 88

Figura 13. Zona de Amortecimento do Parque Estadual da Cantareira (PEC)............................ 89

Figura 14. Principais pressões e ameaças do Parque Estadual da Cantareira. ............................... 91

Figura 15. Imagem de satélite da Estação Ecológica de Ribeirão Preto (EERP), delineada pela cor laranja. 100

Figura 16. Imagem de satélite com zoom para a Estação Ecológica de Ribeirão Preto (EERP), delineado pela cor laranja...................................................................................................... 100

Figura 17. Zona de Amortecimento da Estação Ecológica de Ribeirão Preto (EERP)............... 101

Figura 18. Zoneamento intero da Estação Ecológica de Ribeirão Preto (EERP)......................... 102

Figura 19. Principais pressões e ameaças da EERP. .................................................................... 103

Figura 20. Imagem de satélite da EERP após o incêndio (data: 14/12/2014)............................ 104

Figura 21. Imagem de satélite da Estação Ecológica de Assis (EEcA), delineada pela cor laranja. 108

Figura 22. Zona de Amortecimento da Estação Ecológica de Assis (EEcA)................................ 109

Figura 23. Zoneamento interno da Estação Ecológica de Assis (EEcA). .................................... 110 
Figura 24. Principais pressões e ameaças da EEcA.

111

Figura 25. Delimitação do recorte da pesquisa, a partir de quatro critérios para seleção dos casos de estudos internacionais. 158

Figura 26. Imagem de satélite com zoom para o Sítio Natura 2000 Lendspitz-Maiernigg, delineado pela cor laranja. 162

Figura 27. Imagem de satélite do Sítio Natura 2000 Lendspitz-Maiernigg (LM), delineado pela cor laranja. 162

Figura 28. Principais pressões e ameaças do Sítio Natura 2000 Lendspitz-Maiernigg (LM).... 165

Figura 29. Imagem de satélite do Sítio Natura 2000 Sonian Forest, delineado pela cor laranja..

Figura 30. Principais pressões e ameaças do Sítio Natura 2000 Sonian Forest (SF). 172

Figura 31. Imagem de satélite com zoom do Sítio Natura 2000 e Parque Nacional ZuidKennemerland (PNZK), delineado pela cor laranja. 176

Figura 32. Imagem de satélite do Sítio Natura 2000 e Parque Nacional Zuid-Kennemerland (PNZK), delineado pela cor laranja. 177

Figura 33. Principais pressões e ameaças do Sítio Natura 2000 e Parque Nacional ZuidKennemerland (PNZK). 180

Figura 34. Esquema ilustrando o processo de elaboração de um plano de manejo. 221

Figura 35. Esquema ilustrativo sobre os diferentes níveis de planejamento: estratégico, tático e operacional. 222

Figura 36. Esquema ilustrativo sobre o processo de planejamento (racional, adaptativo e participativo) em áreas protegidas urbanas. 


\section{LISTA DE QUADROS}

Quadro 1. Valores e benefícios das áreas protegidas urbanas.

Quadro 2. Exemplos das principais ameaças (diretas e indiretas) e suas consequências potenciais para áreas protegidas, proposta pela IUCN.

Quadro 3. Exemplos de pressões e ameaças em UCs, propostas por Ervin (2003). 58

Quadro 4. Principais pressões e ameaças que afetam UCs urbanas, propostas por Trzyna (2014).

Quadro 5. UCs do Estado de São Paulo que se enquadraram nos cinco critérios de seleção. ..... 71

Quadro 6. UCs participantes da pesquisa.

Quadro 7. Pontuação e grau de severidade das pressões e/ou ameaças, definidos por Ervin (2003).

Quadro 8. Quadro síntese das principais características e observações referentes aos casos de estudos nacionais.

Quadro 9. Quadro síntese das ações de conservação identificadas para o PEJ, PEC, EERP e EEcA, distribuídas em categorias e subcategorias, segundo as suas finalidades.

Quadro 10. Áreas protegidas urbanas europeias selecionadas para contato, enquadradas nos quatro critérios. 159

Quadro 11. Áreas protegidas participantes do estudo. 160

Quadro 12. Quadro síntese das principais características e observações referentes aos casos de estudos internacionais. 202

Quadro 13. Quadro síntese das ações de conservação identificadas para os Sítios Natura 2000 Lendspitz-Maiernigg, Sonian Forest e Parque Nacional Zuid-Kennemerland, distribuídas em categorias e subcategorias, segundo as suas finalidades.. ......................................................... 206

Quadro 14. Tipos de governança e suas características, de acordo com a IUCN. ...................... 216

Quadro 15. Princípios e considerações gerais de boa governança em áreas protegidas, propostos pela IUCN...

Quadro 16. Categorias, orientações e melhores práticas e exemplos. 224

Quadro 17. Principais diferenças observadas nos casos de estudos nacionais e internacionais. 229 



\section{LISTA DE ABREVIATURAS E SIGLAS}

ANB

APA

APP

ARIE

AWV

CAP

CEEFLORUSP

CETESB

CDB

CONAMA

CONDEMA

CONTEPHAAT

COTEC

CTEEP

DAISIE

DER

DNF

EEA

$\mathrm{EEcA}$

EERP

EFUF

EIA

EMAP

ESEC

ETEPs

FAPESP
Flemish Agency for Nature and Forests of Brussels

Área de Proteção Ambiental

Áreas de Preservação Permanente

Área de Relevante Interesse Ecológico

Agência de Estradas e Tráfego de Bruxelas

Conservation Action Planning

Centro de Extensão e Estudos Florestais da Universidade de São Paulo

Companhia Ambiental do Estado de São Paulo

Convenção sobre a Diversidade Biológica

Conselho Nacional do Meio Ambiente

Conselho Municipal de Defesa ao Meio Ambiente

Conselho de Defesa do Patrimômio Histórico, Artístico, Arqueológico e Turístico do Estado de São Paulo

Comissão Técnico-Científica do Instituto Florestal

Companhia de Transmissão de Energia Elétrica Paulista

Delivering Alien Invasive Species Inventories for Europe

Departamento de Estradas de Rodagem

Direction de la Nature et des Forêts

European Environment Agency

Estação Ecológica de Assis

Estação Ecológica de Ribeirão Preto

European Forum on Urban Forestry

Estudos de Impacto Ambiental

Efetividade de Manejo de Áreas Protegidas

Estação Ecológica

Espaços Territoriais Especialmente Protegidos

Fundação de Amparo à Pesquisa do Estado de São Paulo 
FF

FLONA

IBAMA

IBGE

ICMBio

IF

IUCN

IVN

LM

METT

MMA

MN

MST

ONG

OS

OSCIP

PARNA

PEC

PEJ

PM

PNAP

PNMC

PNUMA

PNZK

PoWPA

PPP

PWN

RAPPAM
Fundação para a Conservação e Produção Florestal do Estado de São Paulo Floresta Nacional

Ibama Instituto Brasileiro do Meio Ambiente e dos Recursos Naturais Renováveis

Bruxelles Environnement

Instituto Chico Mendes de Conservação da Biodiversidade

Instituto Florestal

International Union for Conservation of Nature

Sociedade para a Natureza e Educação Ambiental

Sítio Natura 2000 Lendspitz-Maiernigg

Management Effectiveness Tracking Tool

Ministério do Meio Ambiente

Monumento Natural

Movimento dos Trabalhadores Rurais Sem Terra

Organizações Não Governamentais

Organizações Sociais

Organizações da Sociedade Civil de Interesse Público

Parque Nacional

Parque Estadual da Cantareira

Parque Estadual do Jaraguá

Polícia Militar

Plano Nacional de Áreas Protegidas

Política Nacional sobre Mudança do Clima

Programa das Nações Unidas para o Meio Ambiente

Parque Nacional Zuid-Kennemerland

Programme of Work on Protected Areas

Parcerias Público-Privadas

Autoridades Provinciais de Gestão de Águas (Província Holanda do Norte)

Rapid Assessment and Priorization of Protected Area Management 


\begin{tabular}{|c|c|}
\hline RDS & Reserva de Desenvolvimento Sustentável \\
\hline REBIO & Reserva Biológica \\
\hline REFAU & Reserva de Fauna \\
\hline RENUURB & Rede Nacional de Unidades de Conservação Urbanas \\
\hline RESEX & Reserva Extrativista \\
\hline REVIS & Refúgio da Vida Silvestre \\
\hline RL & Reserva Legal \\
\hline RMSP & Região Metropolitana de São Paulo \\
\hline RPPN & Reserva Particular do Patrimônio Natural \\
\hline SBB & Comissão Florestal \\
\hline SF & Sítio Natura 2000 Sonian Forest \\
\hline SIM & Sistema Integrado de Monitoramento \\
\hline SMA & Secretaria Estadual de Meio Ambiente \\
\hline SNUC & Sistema Nacional de Unidades de Conservação \\
\hline SPA & Special Protection Areas \\
\hline TI & Terra Indígena \\
\hline TQ & Território Quilombola \\
\hline $\mathrm{UC}$ & Unidades de Conservação \\
\hline UE & União Europeia \\
\hline UNEP & United Nations Environment Programme \\
\hline UNESCO & Organização das Nações Unidas para Educação, Ciência e Cultura \\
\hline UNPD & United Nations Population Division \\
\hline UPA & Urban Protected Areas Network \\
\hline WCPA & World Commission on Protected Areas \\
\hline $\mathrm{ZA}$ & Zona de Amortecimento \\
\hline ZEPAM & Zona Especial de Proteção Ambiental \\
\hline ZEE & Zoneamento Ecológico-Econômico \\
\hline ZM & Zona Mista \\
\hline
\end{tabular}





\section{SUMÁRIO}

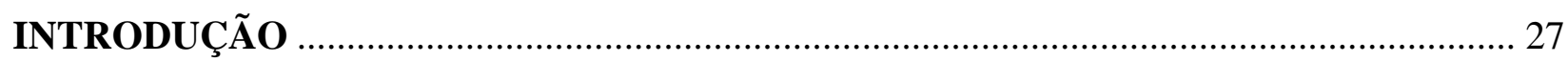

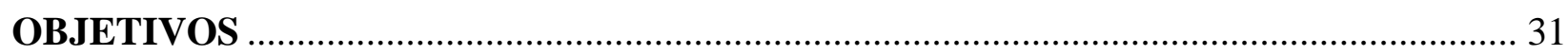

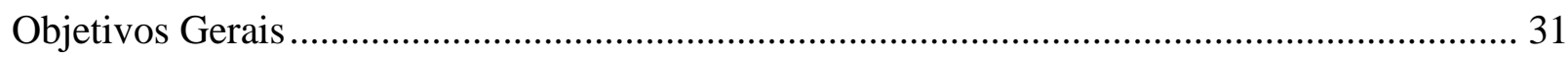

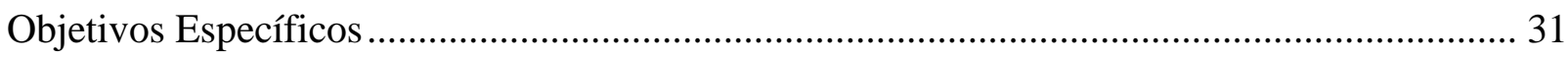

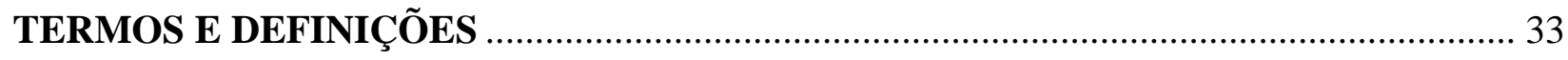

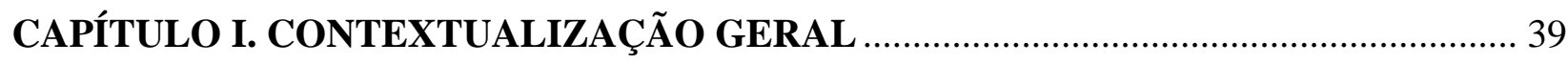

1. O Processo de Urbanização ................................................................................................. 39

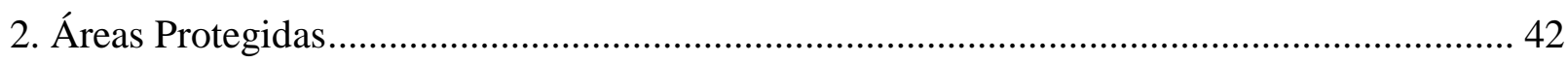

3. Unidades de Conservação Urbanas ....................................................................................... 49

4. Principais Pressões, Ameaças e Desafios Enfrentados pelas Unidades De Conservação

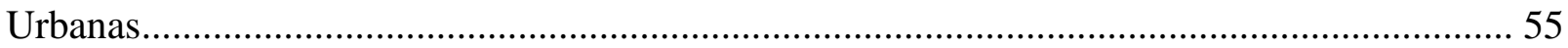

CAPÍTULO II. UNIDADES DE CONSERVAÇÃO URBANAS DO ESTADO DE SÃO

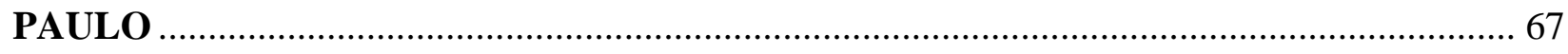

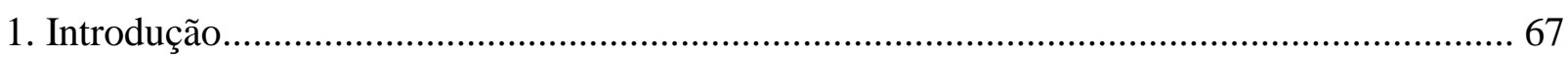

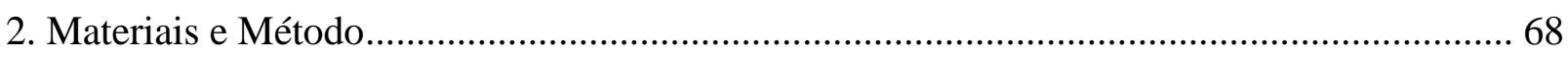

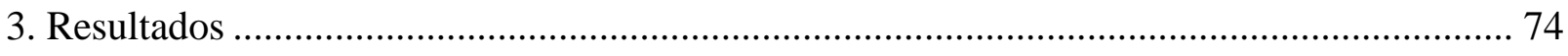

3.1 Parque Estadual do Jaraguá (PEJ) ............................................................................ 75

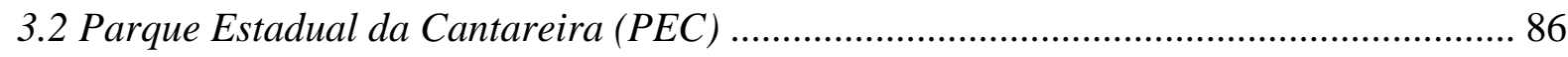

3.3 Estação Ecológica de Ribeirão Preto (EERP) ............................................................... 99

3.4 Estação Ecológica de Assis (EEcA).............................................................................. 107

3.5 Ações de Conservação ............................................................................................. 115

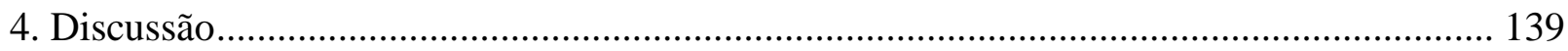

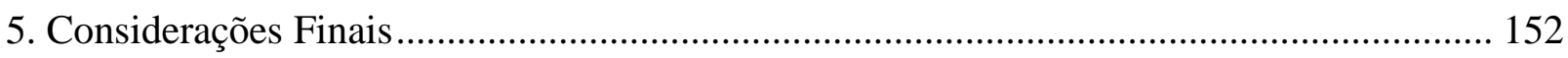

CAPÍTULO III. ÁREAS PROTEGIDAS URBANAS EUROPEIAS ................................... 155

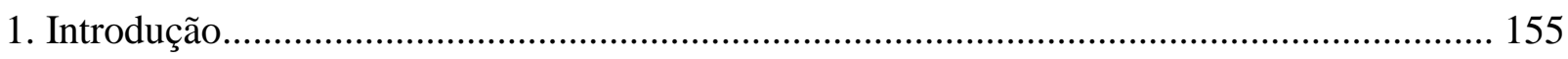

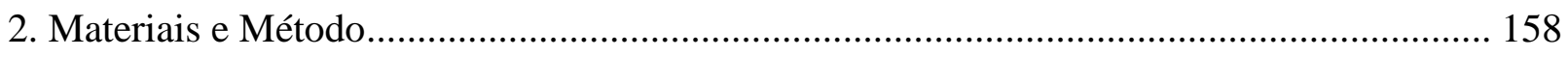

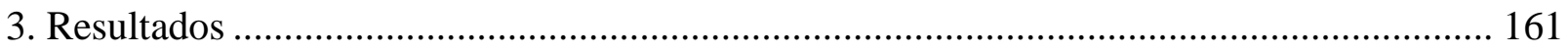

3.1 Sítio Natura 2000 Lendspitz-Maiernigg (LM) ........................................................... 161

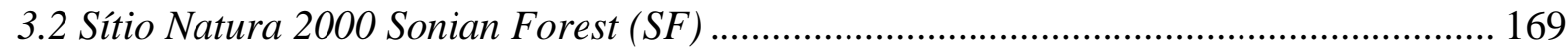

3.3 Sítio Natura 2000 e Parque Nacional Zuid-Kennemerland (PNZK)............................ 176

3.4 Ações de Conservação .............................................................................................. 184 


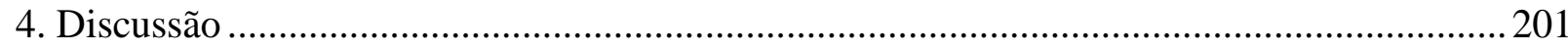

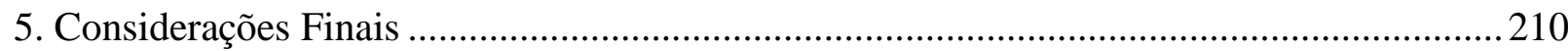

CAPÍtUlo IV. ORIENTAÇões E MELHORES PRÁticas PARA Áreas

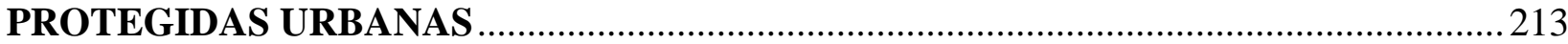

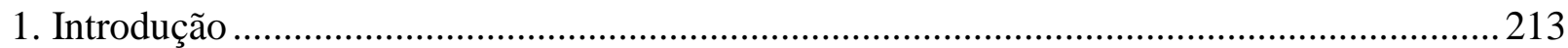

2. Orientações e melhores práticas propostas pela IUCN........................................................215

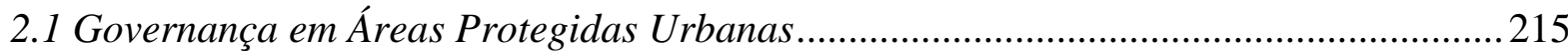

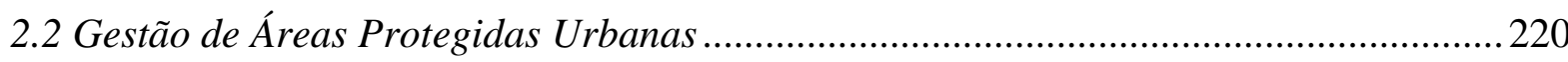

3. Considerações sobre os casos de estudos nacionais e internacionais ...................................222

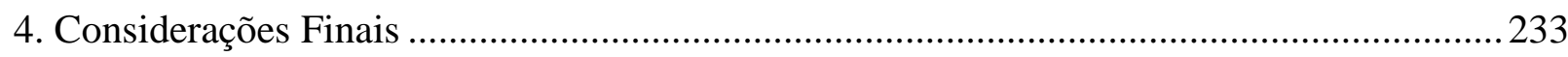

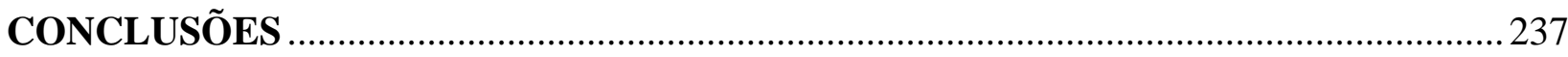

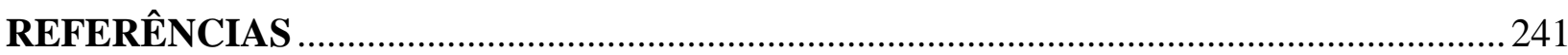

APÊNDICES

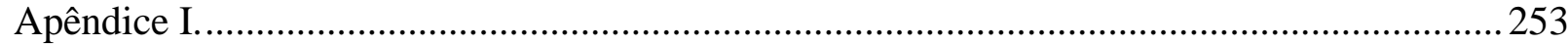

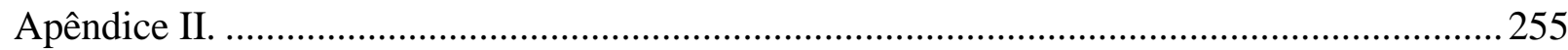

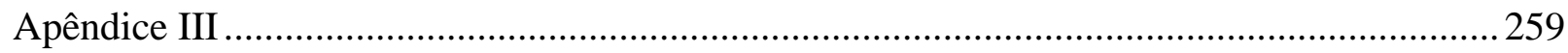

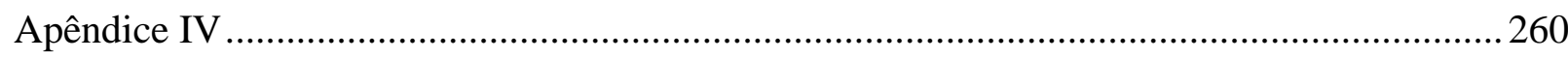

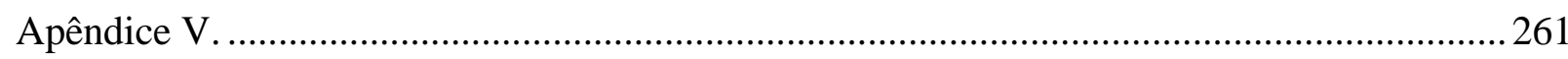

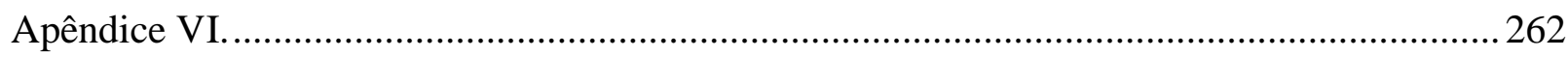

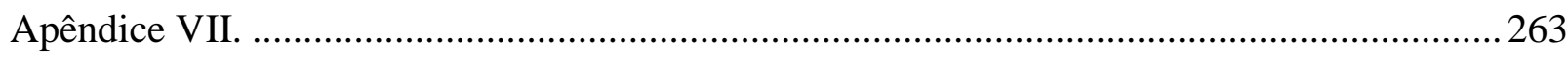

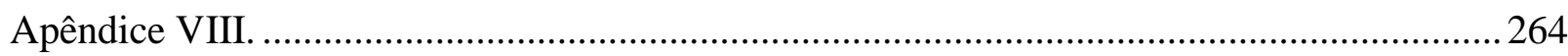

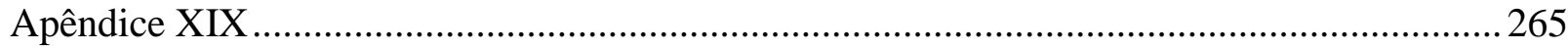

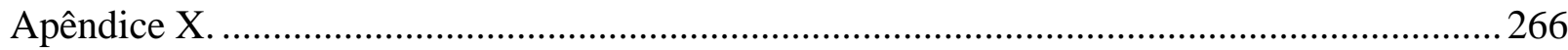

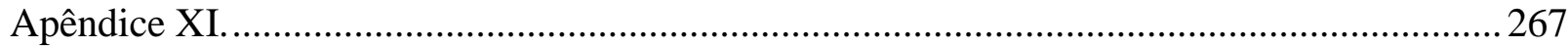

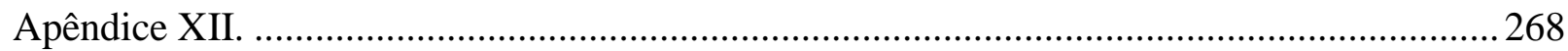

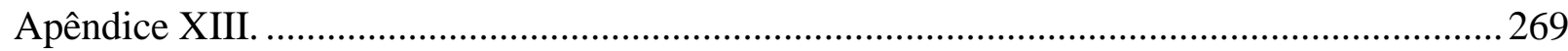

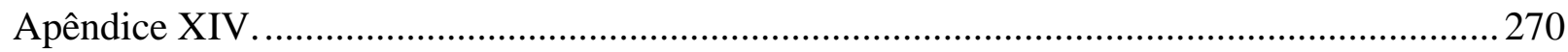

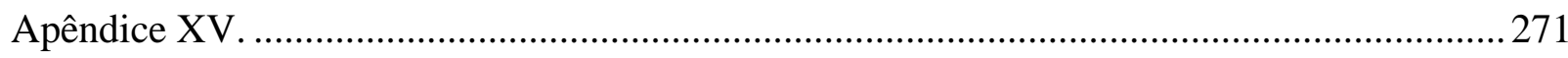

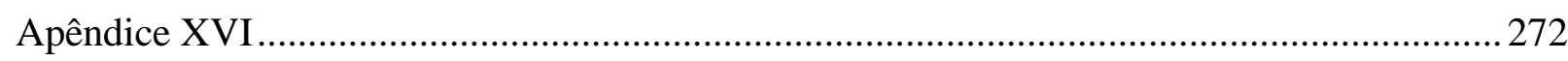




\section{INTRODUÇÃO}

Uma das principais estratégias que vem sendo adotada para a conservação da biodiversidade é a criação de áreas protegidas (CBD, 2011; WORBOYS et al., 2015). Segundo a União Internacional para a Conservação (IUCN), organização internacional que define diretrizes e recomendações para essas áreas (WORBOYS et al., 2015), elas são definidas como "espaço geográfico claramente definido, reconhecido, dedicado e gerido, através de meios eficazes legais ou outros, para alcançar a conservação da natureza a longo prazo com a associação dos serviços ecossistêmicos e valores culturais"1 (DUDLEY, 2008, p.8, tradução nossa). No Brasil, o termo áreas protegidas engloba as áreas de preservação permanente (APPs), reservas legais (RLs) e unidades de conservação (UCs) (MEDEIROS; IRVING; GARAY, 2004).

A criação e implementação das UCs visam contribuir para a manutenção da diversidade biológica e dos recursos genéticos existentes, estabelecendo um controle para o uso e ocupação do solo nos territórios (MEDEIROS, 2006). Elas desempenham um papel fundamental para a saúde do planeta e dos seus habitantes (WORBOYS et al., 2015), trazendo benefícios ambientais, socioeconômicos, estéticos e educacionais (GUIMARÃES; PELLIN, 2015).

As UCs localizadas próximas de áreas urbanas apresentam importantes tarefas, tais como: fornecer uma variedade de serviços ecossistêmicos para as cidades (e.g água potável e redução da poluição atmosférica); contribuir com "infra-estrutura verde"; aumentar a qualidade de vida urbana; auxiliar economias locais através do turismo; promover um maior contato da população com o meio ambiente; proporcionar saúde e bem-estar; formar um eleitorado engajado com a conservação da natureza; oferecer oportunidades de aprendizado sobre o meio ambiente e sustentabilidade (TRYZNA, 2014). De acordo com Watson et al. (2014), a atual crise global de perda de biodiversidade poderia ser muito mais séria sem o estabelecimento de áreas protegidas.

Apesar dos inúmeros benefícios fornecidos por essas áreas, a qualidade de muitas encontrase em declínio (CAREY; DUDLEY; STOLTON, 2000), principalmente devido a existência de pressões e ameaças ${ }^{2}$. Essas áreas vêm sendo pressionadas e ameaçadas por atividades antrópicas, especialmente àquelas localizadas nas zonas urbanas ou de expansão urbana, expondo o problema

\footnotetext{
1 "Clearly defined geographical space, recognised, dedicated and managed, through legal or other effective means, to achieve the long-term conservation of nature with associated ecosystem services and cultural values" (DUDLEY, 2008, p.8).

${ }^{2}$ Definições de pressões e ameaças são apresentadas no item Termos e Definições.
} 
da pesquisa. Algumas das pressões e ameaças observadas são: poluição (local e regional); conversão do uso do solo (transformação de terras protegidas em moradia, assentamentos, e outros usos de não proteção), construção de estradas, rodovias, ferrovias, portos e linhas de transmissão de energia (LTs) e turismo e recreação (ERVIN, 2003; KOTHARI et al., 2015; MATHUR; ONIAL; MAUVAIS, 2015). Assim, os ambientes naturais e os serviços ecossistêmicos fornecidos por eles sofrerão ainda mais com os efeitos significativos do intenso processo de urbanização (BOLUND; HUNHAMMAR, 1999).

Segundo Trzyna (2014), com o estabelecimento de mais áreas urbanizadas no mundo, aumentam-se as chances de seus residentes perderem ou diminuirem o contato com o ambiente natural e seus benefícios, comprometendo a qualidade de vida dessa população. Além disso, diminuem-se as chances de fornecerem suporte político, social e financeiro para a conservação desses locais (TRYZNA, 2014), tornando-as mais vulneráveis.

Além das pressões e ameaças externas, verifica-se também a existência de problemas internos relacionados à gestão de algumas UCs, tais como falta de infraestrutura, recursos financeiros e profissionais qualificados (PUREZA; PELLIN; PADUA, 2015). Como resultado, esses problemas podem impedir com que essas áreas cumpram integralmente com seus objetivos de conservação (CAREY; DUDLEY; STOLTON, 2000).

Em suma, a grande variedade de pressões e ameaças do ambiente urbano, somada a falta de suporte da população e aos problemas de gestão, podem enfraquecer a conservação das áreas protegidas adjacentes às áreas urbanas, afetando prejudicialmente os organismos e ecossistemas. Considerando esses fatos, faz-se necessário conhecer a realidade dessas áreas, seus problemas e suas iniciativas de conservação, para que assim seja possível criar uma estratégia diferenciada para a conservação dessas áreas, a qual é urgente. Além disso, estudos que mostrem como conciliar a conservação da natureza com o desenvolvimento urbano são críticos para que essas áreas continuem exercendo funções como a proteção da biodiversidade e o fornecimento de serviços ecossistêmicos.

Considerando o problema da pesquisa apresentado, esse trabalho se propõe a responder as seguintes questões: I) Quais são as principais pressões e ameaças enfrentadas por unidades de conservação localizadas em áreas urbanas ou de expansão urbana? II) Como as equipes de gestão responsáveis pelas áreas protegidas urbanas podem conciliar a conservação da biodiversidade com o desenvolvimento urbano? Isto é, quais tipos de ações de conservação vêm sendo adotadas pelos 
gestores dessas áreas? III) Quais são as orientações e melhores práticas recomendadas pelos órgãos internacionais e nacionais para enfrentar os desafios urbanos?

Para respondê-las, foram realizadas entrevistas semiestruturadas com os gestores responsáveis de determinadas UCs nacionais e internacionais, as quais foram escolhidas como casos de estudos por estarem sofrendo com pressões e ameaças tipicamente urbanas. De maneira geral, dada a abrangência do trabalho, foi feito um recorte na pesquisa, optando-se por UCs do Estado de São Paulo, bem como por áreas protegidas urbanas do continente Europeu, devido aos seus elevados índices de urbanização ${ }^{3}$. Dessa forma, o presente trabalho será dividido em quatro capítulos, detalhados a seguir:

No primeiro capítulo, realiza-se uma contextualização geral sobre UCs urbanas, levantando-se as principais características, pressões, ameaças e demais desafios que as envolvem, através de uma pesquisa documental e bibliográfica. Desse modo, discuti-se acerca dos seguintes tópicos: impactos da urbanização para as UCs urbanas; valores e benefícios ambientais, socioeconômicos, culturais, estéticos, educacionais ou de sensibilização; diferenças conceituais entre UCs urbanas, áreas verdes e parques urbanos; principais características pelas quais se destacam; iniciativas de estudos na área; principais pressões e ameaças, bem como problemas de gestão.

Para o segundo e terceiro capítulos, realizam-se casos de estudos com quatro UCs de proteção integral do Estado de São Paulo e três áreas protegidas urbanas do continente europeu, respectivamente. Os critérios para seleção desses locais são detalhados em cada capítulo. De maneira geral, como primeira etapa, é feita uma breve caracterização para cada área protegida, com o intuito de apresentar sua importância biológica, social e econômica para a região em que se encontra, bem como a realidade em que está inserida. Na segunda etapa, as principais pressões e ameaças urbanas são identificadas e avaliadas. Posteriormente, as principais ações de conservação que vêm sendo implementadas pelas equipes de gestão são identificadas e categorizadas conforme as suas diferentes finalidades (ações de proteção, uso público, integração, manejo, conhecimento, operacionalização).

No quarto e último capítulo, são identificadas as principais orientações e melhores práticas de governança e gestão em áreas protegidas urbanas, propostas pela IUCN, as quais seguem as

\footnotetext{
${ }^{3}$ As UCs nacionais e internacionais foram selecionadas segundo critérios particulares, detalhados posteriormente nos métodos dos capítulos II e III, respectivamente.
} 
recomendações atuais da Convenção sobre Diversidade Biológica (CDB). Além disso, realiza-se uma comparação dos diferentes modelos de governança e gestão verificados para os casos de estudos nacionais e internacionais.

De maneira geral, espera-se que os resultados obtidos contribuam com a gestão e governança desses espaços e com o reconhecimento da sua importância (ambiental, social, econômica, educativa e científica) para as populações urbanas e seus territórios. 


\section{OBJETIVOS}

\section{Objetivos Gerais}

Analisar os procedimentos e práticas de governança e gestão utilizados para a mitigação das principais pressões e ameaças em unidades de conservação urbanas.

\section{Objetivos Específicos}

- Identificar as principais pressões e ameaças de determinadas unidades de conservação urbanas nacionais (localizadas no Estado de São Paulo) e internacionais (localizadas no continente europeu) junto às suas equipes de gestão;

- Avaliar o grau de severidade das principais pressões e ameaças identificadas;

- Identificar as orientações e melhores práticas recomendadas pela IUCN para a resolução das principais pressões e ameaças em unidades de conservação urbanas;

- Comparar os modelos de governança e gestão das unidades de conservação urbanas nacionais e internacionais. 


\section{TERMOS E DEFINIÇÕES}

No presente item são apresentadas definições e considerações a respeito dos principais termos e conceitos relacionados às áreas protegidas utilizados no presente estudo, para melhor compreensão da leitura.

Primeiramente, é importante ressaltar que a União Internacional para a Conservação (IUCN) é internacionalmente reconhecida como uma das principais autoridades globais, responsável por elaborar definições e diretrizes para as áreas protegidas mundiais, as quais seguem as recomendações atuais da Convenção sobre Diversidade Biológica (CDB). Logo, com a disseminação de áreas protegidas pelo mundo, uma série de nomenclaturas e classificações foram surgindo, sendo necessário uma sistematização dos termos e conceitos. Desse modo, a Comissão Mundial de Áreas Protegidas ${ }^{4}$ (WCPA), uma das seis comissões da IUCN, é responsável por sistematizá-los e orientar as melhores práticas para as áreas protegidas (GULEZ, 1992).

Atualmente a IUCN define as áreas protegidas como: “espaço geográfico claramente definido, reconhecido, dedicado e gerido, através de meios eficazes legais ou outros, para alcançar a conservação da natureza a longo prazo com a associação dos serviços ecossistêmicos e valores culturais" (DUDLEY, 2008, p.8, tradução nossa).

No entanto, na legislação brasileira não há um conceito único para área protegida, sendo um termo utilizado em diferentes contextos e com significados específicos. Segundo o modelo brasileiro de áreas protegidas, este é composto por Áreas de Preservação Permanente (APPs), Reservas Legais (RLs), ambas instituídas pela Lei Federal nº12.651/2012, bem como por Unidades de Conservação (UCs), instituídas pela Lei Federal nº.985/2000 (estabelece o Sistema Nacional de Unidades de Conservação - SNUC) (MEDEIROS; IRVING; GARAY, 2004). De acordo com o SNUC, as UCs são definidas como:

Espaço territorial e seus recursos ambientais, incluindo as águas jurisdicionais, com características naturais relevantes, legalmente instituídos pelo Poder Público, com objetivos de conservação e limites definidos, sob regime especial de administração, ao qual se aplicam garantias adequadas de proteção (BRASIL, 2000, Art. 2º inciso I).

\footnotetext{
${ }^{4}$ World Commission on Protected Areas (WCPA).

5 "Clearly defined geographical space, recognised, dedicated and managed, through legal or other effective means, to achieve the long-term conservation of nature with associated ecosystem services and cultural values" (DUDLEY, 2008, p.8).
} 
O manejo das UCs é definido pelo SNUC como "todo e qualquer procedimento que vise assegurar a conservação da diversidade biológica e dos ecossistemas" (BRASIL, 2000, Art. 2º inciso VIII). A IUCN utiliza o termo management para a mesma função, definida como "o processo de reunir e usar conjuntos de recursos de uma maneira direcionada a objetivos para realizar tarefas em uma organização" (HITT et al., 2011, p.4). Contudo, Faria (2004) adverte que, no âmbito da conservação, os termos manejo, administração e gestão são frequentemente utilizados como sinônimos, apesar de possuírem algumas diferenças conceituais. Em suma, todos esses termos são empregados quando se referem as ações diárias realizadas nas UCs.

Desse modo, Faria (2004) realiza uma extensa revisão dos termos e definições e assim, conclui que o termo mais adequado (abrangente e fidedigno) para se referir as ações diárias realizadas nas UCs é gestão, definida como:

\footnotetext{
A equilibrada coordenação dos componentes técnicos e operacionais (recursos humanos, materiais, financeiros) e os diversos atores sociais que incidem sobre o desenvolvimento da área, de maneira tal a obter-se a eficácia requerida para se lograr os objetivos para os quais a unidade foi criada e a manutenção da produtividade dos ecossistemas abrangidos (FARIA, 2004, p.39).
}

Verifica-se que as UCs necessitam de uma gestão adequada e de qualidade para responder a múltiplas questões e responsabilidades (WORBOYS; TRZYNA, 2014). Para se referir a uma gestão adequada, observa-se que a IUCN utiliza o termo management effectiveness. Desse modo, conforme ressaltado por Faria (2004) e Ludka (2012), os termos efetividade, eficácia e eficiência são frequentemente confundidos ou também utilizados como sinônimos.

Ludka (2012) analisa o significado dos termos no campo da ciência da administração e chega a conclusão de que: “(...) o conceito de eficácia remete ao grau de cumprimento de objetivos e metas pré-definidos; a eficiência relaciona-se ao cumprimento dessas ações com o mínimo de insumos; enquanto a efetividade passa a ideia de busca pela realização da missão da organização" (LUDKA, 2012, p.30). Similarmente à autora, o presente trabalho opta por utilizar o termo efetividade. Segundo Oxford (2017), o termo effectiveness ou efetividade pode ser definido como o grau em que algo é bem sucedido em produzir um resultado desejado.

$\mathrm{Na}$ tentativa de agir contra a perda da biodiversidade existente, pesquisadores da área da conservação vêm buscando definir, classificar e avaliar os diversos problemas que afetam o atual status da biodiversidade (SALAFSKY et al., 2008; MATHUR; ONIAL; MAUVAIS, 2015). Como resultado, surgiram diversas definições para esses problemas (e.g. ameaças, pressões, estresses). 
Além disso, surgiram diversos métodos de avaliação (e.g. Rapid Assessment and Priorization of Protected Area Management - RAPPAM; Management Effectiveness Tracking Tool - METT e Efetividade de Manejo de Áreas Protegidas - EMAP), os quais identificam os principais problemas presentes em áreas protegidas (SALAFSKY et al., 2003). Logo, outros termos que normalmente são confundidos e que devem ser compreendidos são pressões e ameaças.

Nesse contexto, uma das propostas para uma classificação dos diversos problemas que afetam o atual status da biodiversidade no planeta é a proposta por Salafsky et al. (2008). Ela é uma classificação mais geral, onde os autores recomendam a utilização dos termos ameaça ${ }^{6}$, definido como:

As atividades ou processos humanos próximos que causaram, estão causando, ou podem causar a destruição, degradação e/ou comprometimento da biodiversidade (por exemplo, pesca insustentável ou exploração madeireira) (...) as ameaças podem ser passadas (históricas), contínuas e/ou prováveis de ocorrer no futuro (SALAFSKY et al., 2008, p.898, tradução nossa)

Ressalta-se que esses autores consideram o termo ameaça como sinônimo de estresse e pressões (SALAFSKY et al., 2008). Já a IUCN utiliza uma classificação mais específica para esses problemas, criada por Worboys et al. (2006) e adaptada por Mathur, Onial e Mauvais (2015), utilizando o termo ameaças diretas e indiretas. As ameaças diretas:

Resultam da proximidade (em geral, ocorrem dentro da área protegida) de atividades humanas ou processos que causam a degradação dos valores de área protegidas e impedem o progresso no sentido de cumprir os seus objetivos de conservação"7 (MATHUR; ONIAL; MAUVAIS, 2015, p. 476).

Já as ameaças indiretas “(...) são aquelas que surgem de fora das áreas protegidas, mas que afetam os valores dentro de áreas protegidas e comprometer os seus objetivos de conservação" 8 (MATHUR; ONIAL; MAUVAIS, 2015, p. 479, tradução nossa).

Outro autor propõe a diferenciação entre ameças e pressões (ERVIN, 2003), sendo as últimas definidas como:

\footnotetext{
6 "The proximate human activities or processes that have caused, are causing, or may cause the destruction, degradation, and/or impairment of biodiversity targets (e.g., unsustainable fishing or logging). Direct threats are synonymous with sources of stress and proximate pressures. Threats can be past (historical), ongoing, and/or likely to occur in the future" (SALAFSKY et al., 2008, p.898).

7 "Direct threats result from proximate (in general, within the protected area) human activities or processes that cause the degradation of protected area values and hinder progress towards meeting its conservation goals" (MATHUR; ONIAL; MAUVAIS, 2015, p.476).

8 "Indirect threats are those that arise from outside protected areas, but which affect values within protected areas and jeopardise their conservation goals" (MATHUR; ONIAL; MAUVAIS, 2015, p. 479).
} 
Processos, ações ou eventos, que já tiveram um impacto prejudicial sobre a integridade da unidade de conservação (e.g. aqueles que resultaram em uma diminuição da diversidade ou capacidade biológica, e/ou um emprobrecimento dos recursos naturais da unidade). As pressões abrangem as atividades legais e ilegais e podem resultar dos impactos diretos ou indiretos de tais forças (ERVIN, 2003, p.56).

Diferentemente, o autor define ameaças como "processos, atividades ou eventos potenciais pelos quais um impacto prejudicial provavelmente ocorrerá ou continuará no futuro" (ERVIN, 2003, p.55). Em suma, as pressões são ações que tiveram algum impacto prejudicial para a UC nos últimos cinco anos, ao passo que as ameaças são possíveis ações que poderão causar impactos às unidades nos próximos cinco anos (ERVIN, 2003). Alguns exemplos de pressões e ameaças citadas pelo autor: extrativismo de madeira (legal ou ilegal), conversão do uso do solo (transformação de terras protegidas em moradia, assentamentos, estradas, agricultura, reflorestamento, entre outros); mineração (atividades de escavação, exploração de recursos subterrâneos e resíduos produzidos dessas atividades); pastagem; construção de barragens; caça (para comércio ilegal ou subsistência); coleta de produtos não madeireiros (alimentos, plantas medicinais, resinas, entre outros); turismo e recreação; disposição de resíduos; processos semi-naturais (processos naturais magnificados pela intervenção antrópicas - ex: incêndios catastróficos); influências transfronteiriças (poluição local e regional, acidificação, inundações, entre outros) e espécies exóticas invasoras (introduzidos intencionalmente ou inadvertidamente por humanos). Desse modo, o presente trabalho opta por utilizar os termos pressões e ameaças recomendados por Ervin (2003), por serem termos mais fidedignos ao contexto das áreas protegidas e por permitirem especificar a ocorrência, abrangência, impacto e a permanência dos problemas que afetam essas áreas (ERVIN, 2003).

Outro termo utilizado no presente trabalho é impacto. De acordo com a definição proposta pelo mesmo autor (ERVIN, 2003), impacto é "o grau em que a pressão afeta diretamente ou indiretamente os recursos da unidade de conservação" (ERVIN, 2003, p.55).

Em relação as iniciativas adotadas pelas equipes de gestão que visam a diminuição dos impactos ou solução das pressões e ameaças, observa-se que Ervin (2003) não define um termo para essas iniciativas, mas utiliza frequentemente o termo mitigação, tais como em: “(...) a prevenção e a mitigação de ameaças” (ERVIN, 2003, p.12); “(...) uma análise de ameaças também identifica os passos específicos para a mitigação e a restauração dos impactos das pressões passadas e para a prevenção de ameaças futuras” (ERVIN, 2003, p.31); “(...) fortalecer as ações de prevenção de ameaças e de mitigação mediante o desenvolvimento de programas apropriados, visando às unidades de conservação sob maior risco" (ERVIN, 2003, p.47). 
Já Salafsky et al. (2008) propõe o uso do termo ações de conservação ${ }^{9}$, definidas como:

Intervenções empreendidas por uma equipe de projetos ou parceiros, direcionadas para alcançar os objetivos dos projetos e as metas de conservação (...) As ações podem ser aplicadas a fatores contribuintes, ameaças ou diretamente aos próprios alvos. As ações de conservação são "mais ou menos" sinônimos de estratégias, intervenções, atividades, respostas e medidas (no sentido da ação, e não no sentido de monitoramento)" (SALAFSKY et al. 2008, p.899).

Visto que o termo ações de conservação é mais abrangente e fidedigno ao contexto do presente trabalho, opta-se portanto por utilizar a definição de Salafsky et al. (2008).

9 "Interventions undertaken by project staff or partners designed to reach the project's objectives and ultimate conservation goals (...) actions can be applied to contributing factors, direct threats, or directly to the targets themselves. Conservation actions are roughly synonymous with strategies, interventions, activities, responses, and measures (in the action sense, not the monitoring sense)." (SALAFSKY et al., 2008, p.899). 


\section{CAPÍTULO I. CONTEXTUALIZAÇÃO GERAL}

O presente capítulo tem como objetivo fornecer elementos para o aprofundamento da discussão sobre as unidades de conservação (UCs) urbanas. Considerando isso, inicialmente é apresentado um breve contexto sobre o processo de urbanização, os seus impactos para os remanescentes de vegetação nativa e sobre o valor da biodiversidade nas áreas urbanas. Também se discute sobre a importância da criação e implementação das UCs, com um foco nas principais características daquelas localizadas em zonas urbanas ou de expansão urbana. Assim, é comentado brevemente sobre o histórico de criação das UCs, bem como as diferenças conceituais de UCs urbanas, áreas verdes e parques urbanos. Além disso, comenta-se sobre os diversos benefícios sociais, culturais, econômicos e ambientais desses espaços, a importância desses locais para a população urbana, bem como as principais iniciativas de estudos na área. Por fim, discute-se sobre as principais ameaças urbanas, bem como os diversos desafios enfrentados por essas unidades.

Dessa forma, propõem-se evidenciar a importância das UCs para as áreas urbanas, tirandoos do cenário de invisibilidade. Além disso, pretende-se contribuir para a discussão das principais pressões e ameaças enfrentadas por elas, visando uma melhor compreensão dos seus principais problemas, bem como das suas potencialidades econômicas, sociais e ambientais.

\section{O Processo de Urbanização}

Durante os últimos três séculos, verifica-se que as atividades humanas vêm atingindo um nível em que podem danificar os sistemas que mantém o planeta em equilíbrio, ameaçando a sobrevivência das espécies (STEFFEN et al., 2004). Esse período é conhecido como Antropoceno, caracterizado pelo aumento dos efeitos das atividades antrópicas sobre o ambiente global (CRUTZEN, 2002), devido principalmente à crescente dependência dos combustíveis fósseis e das formas industrializadas de agricultura (STEFFEN et al., 2004).

No Antropoceno, verifica-se que os limites planetários (os quais definem o espaço de operação segura para as atividades antrópicas) relativos a dois sistemas: "fluxos bioquímicos" (ciclos do nitrogênio e fósforo) e "integridade da biosfera" (diversidade genética) já foram ultrapassados (isto é, se encontram na zona de alto risco) (STEFFEN et al., 2015). Logo, há evidências crescentes de que as atividades antrópicas estão ameaçando a resiliência dos sistemas terrestres e estas poderão trazer danos irreversíveis para o ambiente (STEFFEN et al., 2015). 
Nesse contexto, o modo de produção atual faz com que cada vez mais o mundo se torne urbano. A urbanização se refere ao "processo pelo qual as zonas rurais assumem características urbanas. Também se refere a uma maior concentração de pessoas nos assentamentos humanos"10 (TRZYNA, 2007, p.7, tradução nossa). Logo, o processo de urbanização é atualmente o maior fenômeno das mudanças nos padrões globais de assentamentos humanos (ZHANG, 2016), devido ao aumento de fluxos migratórios para as cidades (MONTGOMERY et al., 2004). Além disso, verifica-se a mudança de uma sociedade predominantemente agrícola, em direção a uma sociedade onde se prevalece as atividades industriais e serviços (MONTGOMERY et al., 2004). Essa intrínsica relação entre o processo de urbanização, industrialização e desenvolvimento econômico iniciou-se na Europa e na América do Norte, ao longo dos séculos XIX e XX, e atualmente pode ser observado em muitos países da América Latina, Caribe e Ásia (UNPD, 2015).

Atualmente, cerca de 54\% da população mundial vive em áreas urbanas (UNPD, 2015), e se as tendências atuais permanecerem, espera-se que em 2050 esse número aumente para $66 \%$ (UNPD, 2015). Apesar dos níveis de crescimento urbano aumentarem nos próximos anos, eles variam muito de acordo com as regiões do mundo (UNPD, 2015). Em 2014, $40 \%$ da população africana e $48 \%$ da população asiática eram urbanas, sendo esperado um aumento ao longo do século para 56\% e 64\%, respectivamente (UNPD, 2015). Já na Europa, 73\% da população era urbana e projeta-se um crescimento superior a 80\% em 2050 (UNPD, 2015). Na América Latina, Caribe e América do Norte, os níveis de urbanização foram ainda maiores, chegando a mais de 80\% (UNPD, 2015). Logo, é esperado que haja um aumento para todas as regiões, em especial para o continente africano e asiático (UNPD, 2015). Assim, cada vez mais o planeta será composto por cidades (ZHANG, 2016) e os ambientes naturais e os serviços ecossistêmicos sofrerão ainda mais com os efeitos significativos do intenso processo de urbanização (BOLUND; HUNHAMMAR, 1999).

No Brasil, os níveis de crescimento urbano são ainda maiores. Em 1950, cerca de 36\% da população brasileira vivia nas cidades (UNPD, 2015) e quinze anos depois, mais da metade da população brasileira era urbana (UNPD, 2015). Em 2015, o nível de urbanização chegou a 85\%, sendo esperado um aumento para 91\% em 2050 (UNPD, 2015). De maneira geral, o processo de urbanização do país foi marcado pela massiva imigração internacional (com a expansão cafeeira e o surto de industrialização) no início do século XX, além do intenso fluxo migratório rural-urbano

10 “(...) the process by which rural areas take on urban characteristics. It also refers to more concentration of people in human settlements" (TRZYNA, 2007, p.7). 
entre as décadas de 60 e 80 (BRITO, 2006). O rápido processo de urbanização, o desenvolvimento econômico desigual e a concentração espacial do desenvolvimento da economia brasileira nos estados de São Paulo e Rio de Janeiro resultaram em uma ocupação do território irregular e desordenada, ampliando os desequilíbrios regionais e sociais (BRITO, 2006).

A crescente concentração de pessoas nas cidades se deve pela busca de melhores oportunidades de vida e está intimamente ligada com o desenvolvimento econômico (ZHANG, 2016). As cidades funcionam como importantes pólos de conhecimento, inovação e especialização de produtos e serviços, sendo agentes de mudanças sociais, culturais, econômicas, tecnológicas e políticas (UNPD, 2011). Além disso, nas cidades existem maiores oportunidades de interação e comunicação entre as pessoas, promovendo o pensamento criativo, a difusão de conhecimento e o desenvolvimento de novas ideias e tecnologias (UNPD, 2011).

Observa-se que, muitas vezes, as cidades estão localizadas em hotspots de biodiversidade (KOVARIK, 2011). Contudo, a política econômica que impulsiona o crescimento das cidades tem sido baseado na apropriação de recursos naturais (PITT; BOULLE, 2010) e exclui a conservação do ambiente e a sustentabilidade dos planejamentos (CRAWHALL, 2015). Como resultado, os remanescentes de vegetação nativa, considerados importantes refúgios para a biodiversidade nas cidades, estão cada vez mais sendo pressionados conforme a expansão das áreas urbanas (SECRETARIADO DA CONVENÇÃO SOBRE DIVERSIDADE BIOLÓGICA, 2012). Ademais, a biodiversidade do entorno dos grandes centros populacionais também é impactada, como por exemplo através da disposição irregular de resíduos sólidos e emissão de poluentes atmosféricos (OLIVEIRA et al., 2011). Além das mudanças ambientais provocadas pelo processo de urbanização, também são observadas mudanças demográficas e sociais, marcadas pelo aumento da desigualdade social (SECRETARIADO DA CONVENÇÃO SOBRE DIVERSIDADE BIOLÓGICA, 2012).

Sabendo disso, é importante reconhecer o potencial das áreas urbanas em abrigar importantes valores de biodiversidade, promover o bem estar humano e tornar os cidadãos conscientes da sua importância (MCKINNEY, 2002; ALVEY et al., 2006; KOVARIK, 2011). A biodiversidade deve ser vista como o principal pilar para o desenvolvimento sustentável, sendo a sua proteção um pré-requisito para a sustentabilidade nas cidades (VROMANS et al., 2010).

A fim de minimizar os impactos da urbanização sobre a biodiversidade, o Secretariado da Convenção sobre Diversidade Biológica (2012) alega que é imprescindível uma gestão e 
planejamento urbano adequados. No entanto, estudos ressaltam que somente o planejamento urbano não é suficiente para mitigar os diversos impactos gerados, sendo necessário haver uma visão ecológica e a sua incorporação nas abordagens de planejamento atuais (ALVEY et al., 2006; OLIVEIRA et al., 2011).

\section{2. Áreas Protegidas}

Uma das principais estratégias adotadas para a conservação das áreas naturais existentes é a criação e implementação de áreas protegidas (MEDEIROS; IRVING; GARAY, 2004). Essa estratégia tem sido positiva, visto que há diversos indicativos de que essas áreas estão contribuindo para a conservação da biodiversidade, além da promoção de bem-estar para as populações (LEVERINGTON et al., 2010a).

No passado, houve tentativas de conservação de espaços geográficos considerados valiosos por possuírem recursos naturais importantes, bem como por possuírem grande beleza cênica nas mais diversas regiões do mundo (MILLER, 1997). No entanto, a concepção inicial de áreas protegidas foi desenvolvida nos Estados Unidos em 1872, a partir da criação do Parque Nacional de Yellowstone, influenciando a criação de milhares de áreas protegidas durante os séculos seguintes (DIEGUES, 1996).

No Brasil, os dados históricos mostram algumas iniciativas relacionadas à conservação dos recursos naturais empregadas pela coroa portuguesa e o governo Imperial (MEDEIROS, 2006). Contudo, a primeira área protegida foi formalmente reconhecida no país somente com a criação do Parque Nacional de Itatiaia, em 1937. A ideia inicial era de áreas naturais "intocáveis" (isto é, como ilhas de contemplação), não sendo permitido atividades humanas impróprias nesses locais (RUNTE, 1979; DIEGUES, 1996; CHAPE et al., 2005). Todavia, essa concepção inicial estabelecida pelos norte-americanos vem sendo gradualmente modificada até os dias de hoje (MORSELLO, 2006).

As áreas protegidas apresentam inúmeros benefícios, tais como auxílio na mitigação e adaptação das mudanças climáticas, conservação da biodiversidade e manutenção dos serviços ecossistêmicos (e.g. água potável e ar limpo), trazendo benefícios diretos e indiretos para a população (STOLTON; DUDLEY, 2010). Nesse sentido, levando em consideração a importância das áreas protegidas, a IUCN criou a Comissão Mundial de Áreas Protegidas (WCPA), composta por diversos especialistas no tema, responsáveis por orientar e dar suporte aos governos sobre as melhores práticas, garantindo com que cumpram os seus objetivos de conservação. 
A IUCN estabeleceu diferentes categorias de acordo com os objetivos de conservação específicos das áreas protegidas, tais como: Ia (strict nature reserve), Ib (wilderness area), II (national park), III (natural monumento or feature), IV (habitat/species management area), V (protected landscape/seascape), VI (protected area with sustainable use of natural resources).

Apesar da ideia de conservar espaços geográficos em áreas protegidas não ser nova, ela só foi internacionalmente reconhecida em 2004, através da CDB (CDB, 2011). Esta Convenção criou o Programa de Trabalho sobre Áreas Protegidas ${ }^{11}$ (PoWPA), consagrando as áreas protegidas como estratégias fundamentais para enfrentar os desafios do século 21 (CDB, 2011) e mais recentemente o Plano Estratégico para a Biodiversidade 2010-20, com 20 Metas de Aichi a serem adotadas até o ano de 2020 (IUCN; UNEP-WCMC, 2016). Essas metas apresentam como objetivo a redução da perda da biodiversidade, buscando compreender as possíveis causas, pressões e estratégias de proteção aos ecossistemas, espécies e diversidade genética (IUCN; UNEP-WCMC, 2016). Dentre as 20 Metas de Aichi, destaca-se a Meta 11, a qual adverte que pelo menos 17\% das áreas terrestres e de águas interiores e 10\% das áreas costeiras e marinhas devem ser protegidas até 2020.

Atualmente, as áreas protegidas oficialmente reconhecidas pelo Banco Mundial de Áreas Protegidas $^{12}$ (WDPA) cobrem cerca de 14,7\% da área terrestre e águas interiores do planeta, bem como 10,1\% da área marinha (figura 1) (IUCN; UNEP-WCMC, 2016).

\footnotetext{
${ }^{11}$ Programme of Work on Protected Areas (PoWPA). Disponível em: < https://www.cbd.int/>. Acesso em: Fev. 2016.

${ }^{12}$ World Database on Protected Areas (WDPA).
} 
Figura 1. Porcentagem de áreas terrestres e marinhas protegidas. A linha verde representa a porcentagem de áreas terrestres e águas interiores cobertas por áreas protegidas (reconhecidas pela WDPA), de acordo com o ano de designação, até a data de Abril de 2016. A linha verde pontilhada representa a meta de cobertura terrestre a ser protegida até 2020 (17\%) pelas Metas de Aichi. Similarmente, a linha azul representa a porcentagem de áreas marinhas dentro da jurisdição nacional cobertas por áreas protegidas (reconhecidas pela WDPA), de acordo com o ano de designação, até a data de Abril de 2016. A linha azul pontilhada representa a meta de cobertura terrestre que deve ser protegida até 2020 (10\%) pelas Metas de Aichi, já atingidas.

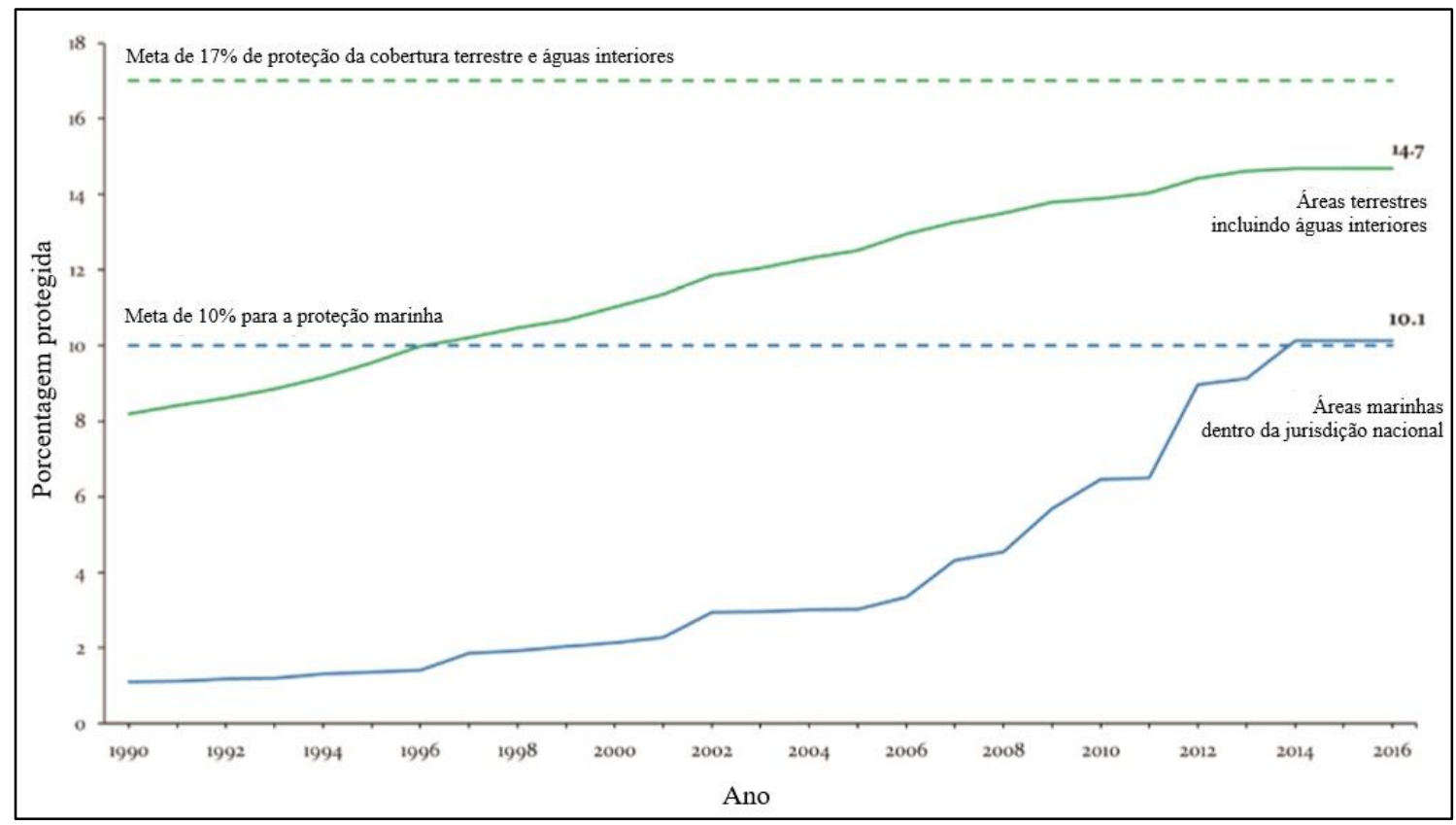

Fonte: IUCN e UNEP-WCMC (2016, tradução nossa).

Verifica-se que para atingir a Meta 11, cerca de 3,1 milhões de $\mathrm{km}^{2}$ devem ser protegidos, ao passo que a cobertura marinha já foi atingida (IUCN; UNEP-WCMC, 2016). Contudo, ressaltase que o número de áreas protegidas e sua extensão nos diferentes países está em constante mudança, à medida que os limites se alteram e as áreas protegidas são adicionadas ou removidas no WDPA (IUCN; UNEP-WCMC, 2016).

No Brasil, o Artigo 225 da Constituição Federal de 1988 destaca como um dos deveres do Poder Público a definição de espaços territoriais especialmente protegidos (ETEPs). De acordo com Silva (2000, p.212), os ETEPs:

São áreas geográficas públicas ou privadas (porção do território nacional) dotadas de atributos ambientais que requeiram sua sujeição, pela lei, a um regime jurídico de interesse público que implique sua relativa imodificabilidade e sua utilização sustentada, tendo em vista a preservação e a proteção da integridade de amostras de toda a diversidade de ecossistemas, a proteção ao processo evolutivo das espécies, a preservação e a proteção dos recursos naturais" (SILVA, 2000, p. 212). 
Os ETEPs podem ser: unidades de conservação (UCs); áreas de preservação permanente (APPs); reservas legais (RLs); terras indígenas (Tis); territórios quilombolas (TQs); áreas tombadas; monumentos arqueológicos e pré-históricos; áreas especiais e locais de interesse turístico; reservas da biosfera; corredores ecológicos; zonas de amortecimento (ZA); espaços protegidos constitucionalmente como patrimônio nacional (e.g. Floresta Amazônica, Mata Atlântica, Serra do Mar); áreas de proteção especial (destinadas à gestão ambiental urbana); jardins botânicos; hortos florestais; jardins zoológicos; terras devolutas e arrecadadas (para proteção dos ecossistemas naturais) e os megaespaços ambientais (PEREIRA; SCARDUA, 2008).

Já o modelo brasileiro de áreas protegidas é composto por APPs, RLs (ambas instituídas pela Lei Federal nº12.651/2012), bem como por UCs (instituídas pela Lei Federal nº.985/2000) (MEDEIROS; IRVING; GARAY, 2004). Desse modo, os ETEPs podem ser considerados gêneros, abrangendo todos os demais conceitos de áreas protegidas, os quais foram "estabelecidos posteriormente por normas infraconstitucionais" (PEREIRA; SCARPA, 2008, p.88) (figura 2).

Figura 2. Representação esquemática de Espaços Territoriais Especialmente Protegidos (ETEPs), Áreas Protegidas (APs) e Unidades de Conservação (UCs).

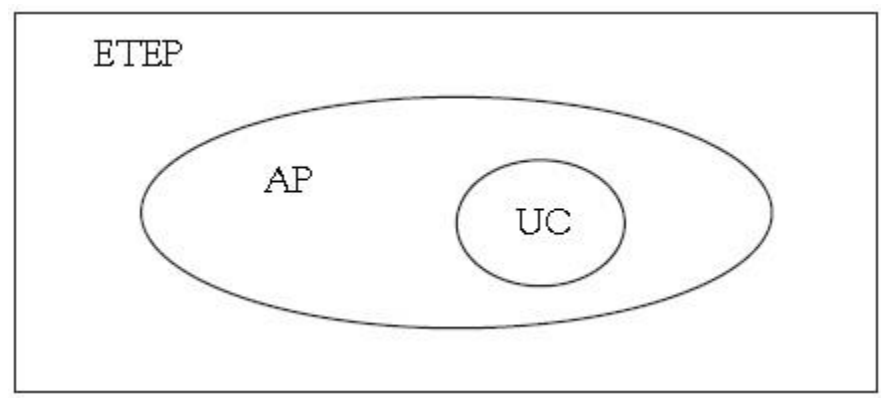

Fonte: Pereira e Scardua (2008).

A Lei Federal n $^{\circ} 9.985 / 2000$ define o SNUC, o qual determina os critérios e normas para a criação, implantação e gestão das UCs. Além disso, essas áreas podem ser privadas ou públicas, em relação ao tipo de propriedade da terra e à sua administração (MORSELLO, 2001; MEDEIROS; IRVING; GAREY, 2004).

O SNUC classifica as UCs em dois grupos específicos: de proteção integral e de uso sustentável (BRASIL, 2000). O principal objetivo das UCs de proteção integral é preservar os recursos naturais, admitindo-se apenas o uso indireto desses e a realização de pesquisas científicas e atividades de educação ambiental, tais como: Estação Ecológica (ESEC), Reserva Biológica (REBIO), Parque Nacional (PARNA), Monumento Natural (MN) e Refúgio da Vida Silvestre 
(REVIS) (BRASIL, 2000). As UCs de uso sustentável têm como objetivo a compatibilização da conservação da natureza com o uso sustentável dos recursos naturais, havendo o consentimento da exploração do meio ambiente de maneira sustentável (BRASIL, 2000). Incluem-se nesse grupo: Área de Proteção Ambiental (APA), Área de Relevante Interesse Ecológico (ARIE), Floresta Nacional (FLONA), Reserva Extrativista (RESEX), Reserva de Fauna (REFAU), Reserva de Desenvolvimento Sustentável (RDS) e Reserva Particular do Patrimônio Natural (RPPN) (BRASIL, 2000). A criação do SNUC foi determinante para que ocorressem as maiores contribuições e avanços na política de expansão e gestão das áreas protegidas no Brasil (PÁDUA, 2002) e, como consequência, um certo disciplinamento na preservação da biodiversidade no país.

A fim de atender o Programa de Trabalho sobre Áreas Protegida estabelecido durante a CDB em 2004, o Governo Brasileiro criou o Plano Nacional de Áreas Protegidas (PNAP), através do Decreto n $n^{\circ} 5.758$ de 13 de abril de 2006. O Plano dá prioridade as áreas protegidas instituídas pelo SNUC, terras indígenas e quilombolas e, dentre os seus objetivos, destacam-se o da redução da taxa de perda de biodiversidade e a manutenção de um sistema de áreas protegidas, as quais sejam efetivamente geridas (MMA, 2015b).

Existem diferentes modelos de gestão para as UCs, podendo ser modelos estatais e não estatais (INSTITUTO SEMEIA, 2015). De maneira geral, a gestão estatal tradicional (figura 3) ocorre através de órgãos públicos, autarquias e fundações, com recursos, bens e agentes do próprio Estado (INSTITUTO SEMEIA, 2015). No caso da administração direta (órgãos públicos), a responsabilidade pelos investimentos na UC ocorre pelo próprio Poder Público, sendo um modelo menos flexível, com limitações gerenciais e orçamentárias e de grande ingerência política da autoridade governamental (INSTITUTO SEMEIA, 2015). Já para o caso de administração indireta (autarquias e fundações públicas), existe uma maior especialização e autonomia frente à administração central, embora ainda haja limitações orçamentárias e enrijecimento da política de recursos humanos (INSTITUTO SEMEIA, 2015). Esse é o caso do Instituto Chico Mendes de Conservação da Biodiversidade (ICMBio), órgão executor responsável pela gestão das UCs federais (BRASIL, 2007). Já para as UCs estaduais e municipais, cabe respectivamente às Secretarias Estaduais e Municipais de Meio Ambiente (e de institutos e fundações ligadas a elas) (BRASIL, 2000). 
Figura 3. Modelos de gestão estatais aplicáveis às UCs.

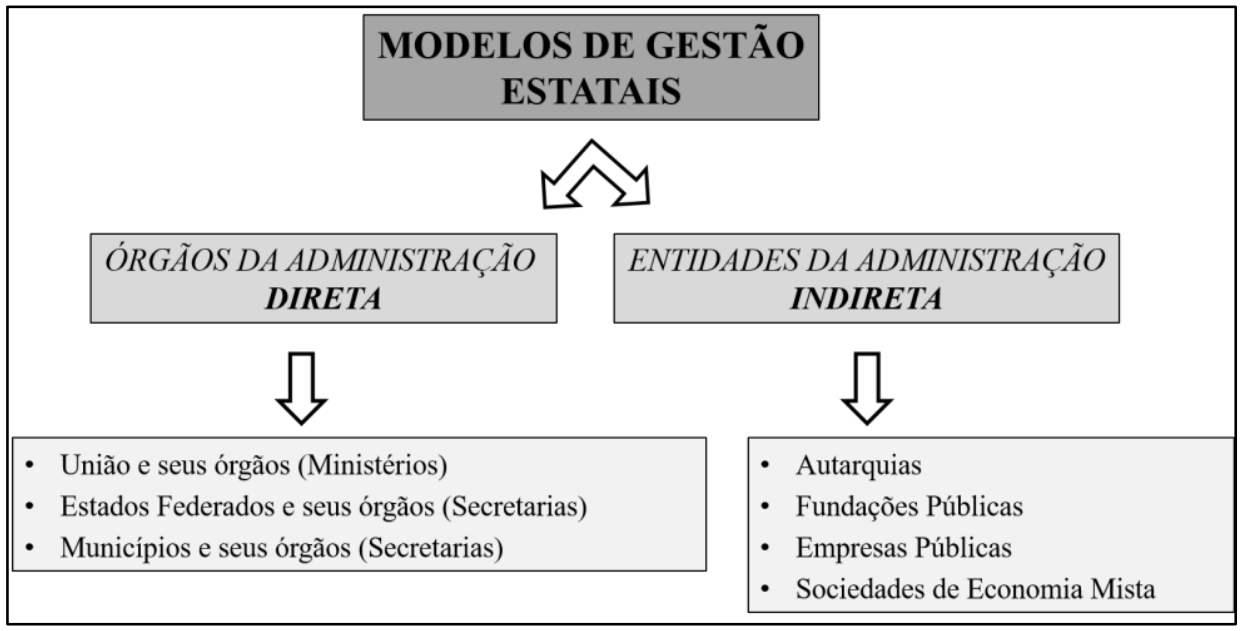

Fonte: Elaborada pela autora (2016), a partir de Instituto Semeia (2015).

Em contrapartida, surge o modelo de gestão não estatal (figura 4), com alternativas para a gestão de serviços de interesse público, destacando o papel das organizações sociais (OS), organizações da sociedade civil de interesse público (OSCIP) $)^{13}$, organizações não governamentais (ONG) e entidades privadas, conhecidas como Parcerias Público-Privadas (PPP) (INSTITUTO SEMEIA, 2015). Além disso, verificam-se as possibilidades de concessões ${ }^{14}$, onde os concessionários recebem o direito de explorar uma atividade dentro da UC, em um período estabelecido através de um contrato com o Poder Público, com a obrigatoriedade de oferecer utilidades e serviços ${ }^{15}$ de qualidade para a população (INSTITUTO SEMEIA, 2015). Esse modelo apresenta maior flexibilidade, especialização e autonomia do que o modelo estatal, embora geralmente as entidades de perfil filantrópico apresentem menor potencial de investimento e reduzida capacidade de assumir atividades vultosas (INSTITUTO SEMEIA, 2015).

\footnotetext{
${ }^{13}$ A gestão de UCs brasileiras pelas OSCIPs é garantida através do Art nº30, da Lei 9.985, de 18/07/2000.

${ }^{14}$ As concessões são diferentes de privatizações, notadamente confundidas no centro do cenário político e econômico das UC brasileiras (a partir da emenda aglutinativa ao projeto de Lei Estadual n²49/2013, que autoriza o Governo Estadual a abrir licitação para concessões em 25 parques estaduais de São Paulo). De maneira geral, define-se privatização como a venda de órgãos ou de empresas estatais para a iniciativa privada, geralmente, por meio de leilões públicos. Já na concessão, a transferência é temporária e a empresa tem prazos definidos, que podem ou não ser renovados, além de regras para explorar o serviço.

${ }^{15}$ Tais como a cobrança de ingressos, transporte, estacionamento, condução de visitantes, atividades ecoturísticas de baixo impacto, entre outras.
} 
Figura 4. Modelos de gestão não estatais aplicáveis às UCs.

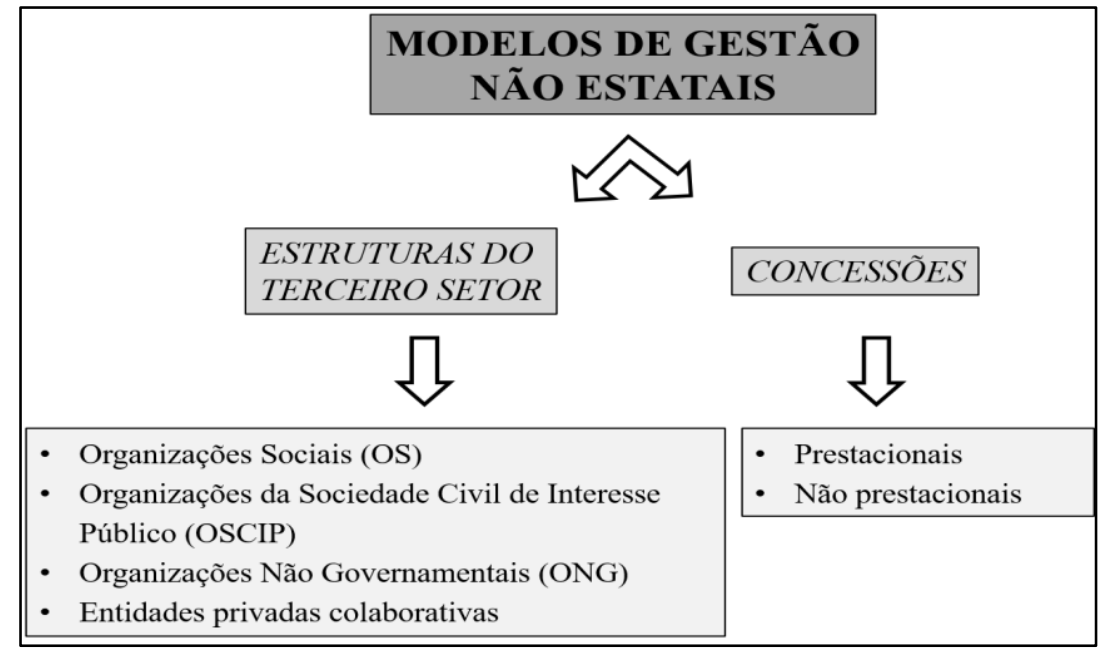

Fonte: Elaborada pela autora (2016), a partir de Instituto Semeia (2015).

Em suma, ambos os modelos (estatal e não estatal) apresentam diversos prós e contras, não existindo um modelo único a ser empregado nas UCs brasileiras, devendo ser analisado pelos gestores as melhores opções a serem empregadas de acordo com cada realidade (INSTITUTO SEMEIA, 2015), bem como garantindo a participação efetiva das populações locais durante a criação, implantação e gestão das UCs (BRASIL, 2000).

No âmbito das UCs brasileiras, existe um órgão consultivo e deliberativo, o Conselho Nacional do Meio Ambiente (CONAMA), responsável por acompanhar a implementação do SNUC, bem como um órgão central, o Ministério do Meio Ambiente (MMA), responsável por coordená-lo (BRASIL, 2000, Art. 6º). Além disso, toda UC deve possuir um conselho gestor paritário (com representantes de órgãos públicos e da sociedade civil) com o objetivo de auxiliar a gestão da UC e buscar a compatibilização dos interesses divergentes do entorno, que envolvem direta ou indiretamente a UC (BRASIL, 2000)

Considerando os fatos apresentados, cabe ao gestor de uma UC integrar informações ecológicas, sociais e econômicas à tomada de decisões técnicas-administrativas e políticas no território onde a UC encontra-se inserida. Nesse sentido, verifica-se como ferramenta de auxílio à gestão das UCs o plano de manejo (BRASIL, 2000, Art. $7^{\circ}$ ), definido como:

Documento técnico mediante o qual, com fundamento nos objetivos gerais de uma unidade de conservação, se estabelece o seu zoneamento e as normas que devem presidir o uso da área e o manejo dos recursos naturais, inclusive a implantação das estruturas físicas necessárias à gestão da unidade; 
O plano de manejo é o documento técnico onde se estabelecem as diretrizes gerais para o planejamento da UC, zoneamento, missão, objetivos específicos de manejo, visão a longo prazo da UC, objetivos estratégicos, normas gerenciais gerais e os programas de manejo. Eles devem ser dinâmicos, monitorados e aprimorados conforme os novos desafios forem surgindo, levando em consideração os pressupostos do planejamento adaptativo e participativo, isto é, com o envolvimento da sociedade em todas as etapas (FERNANDES; HANGAE; MOTA, 2011).

Para que o planejamento da UC seja adequado, é necessário considerar os demais planos existentes no território onde a unidade está inserida, tais como planos diretores, Zoneamento Ecológico-Econômico (ZEE), planos de ordenamento territorial diversos, projetos sociais e estruturais regionais, entre outros. Além disso, devem incluir em seu planejamento concepções estratégicas, táticas e operacionais (FERNANDES; HANGAE; MOTA, 2011).

Nesse contexto, apesar das áreas protegidas serem reconhecidas atualmente como a principal estratégia de conservação da biodiversidade, estudos ressaltam como prioridade a efetividade de gestão nessas áreas (LEVERINGTON et al., 2010a; WATSON et al., 2014; WORBOYS; TRZYNA, 2015). Segundo Hockings et al. (2006), a partir de uma avaliação de efetividade de gestão em uma UC, é possível saber se as metas e objetivos da área estão sendo atingidos. Alguns exemplos de metodologias de avaliação de efetividade são: Rapid Assessment and Priorization of Protected Area Management (RAPPAM); Management Effectiveness Tracking Tool (METT); Enhancing our Heritage; How is Your MPA Doing?; Conservation Action Planning (CAP); WWF-World Bank MPA Score Card; Effectiveness of Management of Protected Areas (EMAP) (LEVERINTON et al., 2008).

Desse modo, verifica-se que, quando a gestão apresenta qualidade e é adequada, essas áreas são capazes de proteger os atributos ecológicos, a biodiversidade e auxiliarem no fornecimento de serviços ecossistêmicos essenciais para as populações (WORBOYS et al., 2015), além de serem uma ferramenta essencial no combate das diversas pressões e ameaças da atualidade (LEVERINGTON et al., 2010b).

\section{Unidades de Conservação Urbanas}

As áreas naturais inseridas nas cidades podem apresentar diferentes nomenclaturas e categorias (e.g. áreas verdes, parques urbanos, UCs urbanas) conforme os seus objetivos específicos, sendo importante defini-las. Primeiramente, a zona urbana dos municípios é composta 
por três sistemas: sistemas de espaços com construção (e.g. habitação, indústria e comércio), sistemas de espaços de integração urbana (e.g. rede rodoferroviária) e sistemas de espaços livres de construção (e.g. praças, parques e águas superficiais) (CAVALHEIRO et al.,1999). Em relação aos espaços livres de construção, estes podem ser privados, potencialmente coletivos, ou públicos e são definidos como:

Espaço urbano ao ar livre, destinado a todo tipo de utilização que se relacione com caminhadas, descanso, passeios, práticas de esportes e, em geral, a recreação e entretenimento em horas de ócio; os locais de passeios a pé devem oferecer segurança e comodidade com separação total da calçada em relação aos veículos; os caminhos devem ser agradáveis, variados e pitorescos; os locais onde as pessoas se locomovem por meios motorizados não devem ser considerados como espaços livres." (CAVALHEIRO et al., 1999, p.1)

Observa-se que as áreas verdes se enquandram nos sistemas de espaços livres de construção. Levando em consideração os esforços realizados por diversos autores para definir os elementos que compõe os espaços livres, Benini e Martin (2010, p.77) estabelecem uma proposta de conceituação para área verde:

Todo espaço livre (área verde/lazer) que foi afetado como de uso comum e que apresente algum tipo de vegetação (espontânea ou plantada), que possa contribuir em termos ambientais (fotossíntese, evapotranspiração, sombreamento, permeabilidade, conservação da biodiversidade e mitigue os efeitos da poluição sonora e atmosférica) e que também seja utilizado com objetivos sociais, ecológicos, científicos ou culturais.

Já para os parques urbanos, o Ministério do Meio Ambiente (MMA) vem utilizando a definição proposta por Lima et al. (1994): "uma área verde com função ecológica, estética e de lazer, no entanto, com uma extensão maior que as praças e jardins públicos”16. Estes, “(...) são construídos para atender as necessidades de lazer e recreação do cidadão", ao passo que os parques pertencentes ao SNUC “(...) têm, em geral, como objetivo principal a preservação dos recursos naturais e, em especial, a biodiversidade in situ" (BALOTTA; BITTAR, 2009, p.4).

De acordo com Trzyna (2014, p.4), as áreas protegidas urbanas se diferenciam das demais por estarem inseridas nos centros populacionais ${ }^{17}$ ou localizadas no seu entorno imediato ${ }^{18}$, recebendo impactos diretos ou indiretos das cidades em suas direções. Conforme ressaltado por

16 Disponível em: < http://www.mma.gov.br/cidades-sustentaveis/areas-verdes-urbanas/parques-e-\%C3\%A1reasverdes>. Acesso em: Abr 2016.

17 “(...) a larger population centre for this purpose can be anything from a town to a megacity (...)” (TRZYNA, 2014, p.4)

18 “(...) suburban areas are considered urban (the terms 'peri-urban', 'urban fringe', and 'rural fringe' are also used to describe the zone immediately surrounding an urban area (...)” (TRZYNA, 2014, p.4). 
Guimarães e Pellin (2015), o SNUC não especifica e muito menos menciona sobre as UCs urbanas. No entanto, entende-se que a implementação dessas áreas está prevista com o estabelecimento do Estatuto da Cidade (Lei nº10.257 de 10/07/2001, Art.4º, inciso V, e), Lei que menciona entre os seus instrumentos a instituição de UCs na execução da política urbana.

Trzyna (2014) relata que as áreas protegidas urbanas se destacam por possuir determinadas peculiaridades. Essas áreas podem receber um alto número de visitantes (os quais muitas vezes não vivenciaram experiências em áreas naturais mais remotas); se relacionam com populações urbanas (as quais podem apresentar grande diversidade étnica e econômica - e.g. agências de governo, autoridades políticas, instituições educacionais, formadores de opinião) e por estarem ameaçadas pelo intenso desenvolvimento urbano e seus impactos oriundos (e.g. incêndios, disposição ilegal de resíduos, vandalismo e poluição em geral). Observa-se uma grande diversidade de áreas protegidas urbanas pelo mundo, as quais são encontradas em todas as categorias propostas pela $\mathrm{IUCN}^{19}$.

Existem uma série de estudos que discutem sobre os benefícios de áreas naturais em regiões urbanas, tanto para a qualidade de vida humana quanto para a ambiental (MCNEELY, 2001; MENEZES; MENDES, 2001; GOMES; SOARES, 2003; MELAZO; COLASANTI, 2003; CONNER, 2005; MENEZES, 2005; DUDLEY; STOLTON, 2005; SOUZA, 2010; PITT; BOULLE, 2010; TRZYNA, 2014; CARRUS et al., 2015; MARTINEZ-JUAREZ et al., 2015). Isso se deve principalmente pelo fato dessas áreas fornecerem serviços ecossistêmicos (e.g. fornecimento de água potável, alimentos, ar limpo), essenciais para a sobrevivência das espécies. Pellin et al. (2014) realizaram uma revisão sobre os valores e benefícios das áreas protegidas urbanas, sistematizando-os em quatro grupos: ambientais, socioeconômicos e culturais, estéticos e educacionais ou de sensibilização (quadro 1). Segundo as autoras, "o exercício de separação dos benefícios em grupos de valores é subjetivo, pois, na realidade, os benefícios listados muitas vezes se inter-relacionam" (PELLIN, et al., 2014, p. 346).

\footnotetext{
${ }^{19}$ Tais como: Danshuei River Mangrove Nature Reserve (Taiwan), pertencente à categoria Ia; Wilderness Areas in Angeles National Forest (EUA), da categoria Ib; Calanques National Park (França), categoria II; California Coastal National Monument (EUA), categoria III; Edith Stephens Nature Reserve (África do Sul), categoria IV; Hong Kong Country Parks (Hong Kong), categoria V; Bosque Estatal de Piñones (Porto Rico), categoria VI (TRZYNA, 2014).
} 
Quadro 1. Valores e benefícios das áreas protegidas urbanas.

\begin{tabular}{|c|}
\hline AMBIENTAIS \\
\hline Proteção de uma amostra do ecossistema e da biodiversidade associada. \\
\hline Aumento da permeabilidade do solo em meio urbano. \\
\hline Proteção de cursos de água, nascentes e matas ciliares. \\
\hline Proteção e purificação da água. \\
\hline Drenagem de águas pluviais e controle de enxurradas. \\
\hline Controle de erosão e de movimentos de massa. \\
\hline Controle da poluição hídrica, atmosférica e sonora. \\
\hline Regulação microclimática. \\
\hline SOCIOECONÔMICOS E CULTURAIS \\
\hline Possibilidade de melhoria na qualidade de vida de moradores do entorno e usuários. \\
\hline Conservação do patrimônio histórico-cultural. \\
\hline Valorização imobiliária do entorno. \\
\hline Oportunidade de geração de renda para a comunidade local. \\
\hline Oportunidade de recreação em contato com a natureza para moradores do entorno e usuários. \\
\hline Manutenção e conservação de espaços sagrados. \\
\hline Diminuição do estresse da vida urbana. \\
\hline Provisão de espaço de interação social. \\
\hline ESTÉTICOS \\
\hline Proteção de belezas naturais e diminuição da poluição visual. \\
\hline Descontinuidade da malha urbana. \\
\hline EDUCACIONAIS OU DE SENSIBILIZAÇÃO \\
\hline $\begin{array}{l}\text { Inúmeras possibilidades de atividades de educação ambiental, ligadas tanto ao ensino formal quanto ao ensino } \\
\text { informal. }\end{array}$ \\
\hline Potencial de interação com uma grande quantidade de pessoas que vivem nas imediações. \\
\hline $\begin{array}{l}\text { Potencial de interação com uma grande quantidade de visitantes devido à proximidade dos grandes centros } \\
\text { urbanos. }\end{array}$ \\
\hline $\begin{array}{l}\text { Possibilidade de interação com usuários ocasionais que utilizam a área apenas para passagem ou para realização de } \\
\text { atividades esportivas ou recreativas. }\end{array}$ \\
\hline Facilidade em atender pessoas com necessidades especiais devido ao seu fácil acesso. \\
\hline $\begin{array}{l}\text { Sensibilização de um grande número de pessoas que vivem em ambiente urbano, ressaltando a importância da } \\
\text { conservação dessas áreas naturais. }\end{array}$ \\
\hline
\end{tabular}

Fonte: Guimarães e Pellin (2015).

Assim, verifica-se a importância das áreas protegidas urbanas para o equilíbrio ambiental das cidades, bem como para a qualidade de vida das populações. Visto que cada vez mais o mundo se torna urbano, alguns autores vêm discutindo sobre o papel fundamental dessas áreas como importantes espaços de integração da população urbana com o meio ambiente (através da realização de atividades recreativas, educacionais e culturais), além dos seus objetivos de conservação da biodiversidade in situ (MENEZES; MENDES, 2001; TRZYNA, 2014; PELLIN et 
al., 2014; GUIMARÃES; PELLIN, 2015; WORBOYS; TRZYNA, 2015). Desse modo, a partir do oferecimento de mais espaços de integração, aumentam-se as chances da população urbana em vivenciar experiências com o meio natural, visto que esta tende cada vez mais a perder o contato com o meio ambiente natural com a expansão das áreas urbanas (TRZYNA, 2014). Desse modo, será possível a formação de uma sociedade mais engajada politicamente na defesa do meio ambiente (TRZYNA, 2014).

Para que as UCs urbanas funcionem como espaços livres de lazer, deve haver “(...) um sério compromisso com o zoneamento da unidade para que a recreação não comprometa o equilíbrio dos ecossistemas, já fragilizados por todo o contexto urbano" (MAZZEI; COLESANTI; SANTOS, 2007, p. 42). Contudo, é importante ressaltar que o objetivo de uma UC urbana não é este exclusivamente. As atividades de uso público devem ocorrer conforme a categoria na qual a UC foi designada na sua implementação, respeitando as diretrizes estabelecidas em seu plano de manejo (MAZZEI; COLESANTI; SANTOS, 2007).

Nos últimos anos, observa-se que a IUCN vêm buscando incentivar a comunidade conservacionista a dar maior atenção aos assuntos urbanos ${ }^{20}$, bem como verifica-se um aumento na discussão sobre as áreas protegidas urbanas no contexto internacional e estudos que demonstrem a importância da biodiversidade nas cidades (mostrado em: MCPHERSON, 1994; NOVAK; WALTON, 2005; ALVEY, et al., 2006; SUNDSETH; RAEYMAEKERS, 2006; MCKINNEY, 2002; DEARBON; KARK, 2009; KOVARIK, 2011; WU, 2014; VOIGT; WURSTER, 2015; MORGENROTH et al., 2016). Nesse sentido, destacam-se alguns acontecimentos, como a criação do Grupo de Especialistas Urbanos ${ }^{21}$, formado por pesquisadores e ambientalistas responsáveis por encorajar mais estudos científicos sobre o tema. Como resultado, a IUCN lançou a publicação intitulada "O Imperativo Urbano"22 (TRZYNA, 2004), trazendo os resultados do workshop realizado pelo Congresso Mundial de Parques, ocorrido em 2003. Em 2009, é criada a Rede de Áreas Protegidas Urbanas ${ }^{23}$, uma rede internacional e sem fins lucrativos, organizada por gestores de áreas protegidas, membros da sociedade civil, pesquisadores e instituições, com objetivos de fomentar conhecimento sobre a relação homem-natureza, conduzindo pesquisas especificamente em quatro regiões: Brasil, Índia, Quênia e África do Sul. Em 2014, a IUCN organizou diversos

\footnotetext{
${ }^{20}$ Destaque do histórico de publicações e workshops em áreas protegidas urbanas, disponível em: <http://www.iucnurban.org/leadership---history.html>. Acesso em: Abr 2016.

${ }^{21}$ Urban Specialist Group. Disponível em: < http://www.iucn-urban.org/home.html>. Acesso em: Abr 2016.

${ }^{22}$ The Urban Imperative.

${ }^{23}$ The Urban Protected Areas (UPA) Network. Disponível em: <http://upa-network.org/>. Acesso em: Abr 2016.
} 
eventos sobre o tema no Congresso Mundial de Parques, em Sydney. Ao mesmo tempo, lançou mais uma publicação intitulada "Áreas Protegidas Urbanas: Perfis e Orientações sobre Melhores Práticas" 24 , trazendo definições de conceitos e orientações, com base em uma década de experiência na área.

Outra iniciativa da IUCN, juntamente com o Programa das Nações Unidas para o Meio Ambiente (PNUMA) ${ }^{25}$, foi a criação de uma base de dados mundial de áreas protegidas ${ }^{26}$ online, onde é possível encontrar uma diversidade de áreas protegidas, bem como aquelas localizadas em áreas urbanas. Contudo, Trzyna (2014) ressalta que não há reconhecimento formal internacional para as áreas protegidas urbanas (com exceção da Finlândia, a qual desde o ano de 2000 autoriza a designação de parques nacionais urbanos, com objetivos primordiais de preservar a biodiversidade urbana), bem como existe a necessidade de se criar um inventário global sobre elas (TRZYNA, 2014). Além disso, de maneira geral, existe uma carência de informações sobre a qualidade e os resultados oriundos da gestão das áreas protegidas (GELDMANN et al., 2015).

No Brasil, destacam-se como as primeiras unidades de conservação urbanas o Parque Nacional da Tijuca, no Estado do Rio de Janeiro e o Parque Estadual da Cantareira, em São Paulo (GUIMARÃES; PELLIN, 2015). A principal motivação para a criação desses parques foi a proteção dos recursos hídricos, os quais estavam sendo ameaçados pela expansão das atividades antrópicas do século XVIII e XIX, comprometendo o abastecimento de água para a população urbana (GUIMARÃES; PELLIN, 2015).

Contudo, verifica-se o início da discussão sobre as UCs urbanas durante o "Seminário Internacional Rio 2012 BiodiverCities - Unidades de Conservação urbanas: desafios, atores, espaços". Como resultado, similarmente à UPA, criou-se a Rede Nacional de Unidades de Conservação Urbanas (RENUURB), uma rede online, formada por gestores de UCs urbanas, pesquisadores, especialistas em planejamento urbano, representantes governamentais, ONGs, entre outros $^{27}$. O principal objetivo da RENUURB é criar uma plataforma de compartilhamento de experiências na área, a fim de fortalecer o papel dessas unidades nas cidades (GUIMARÃES; PELLIN, 2015).

${ }^{24}$ Urban Protected Areas: Profiles and best practice guidelines.

${ }^{25}$ United Nations Environment Programme (UNEP).

${ }^{26}$ The World Database of Protected Areas (WDPA). Disponível em: 〈http://protectedplanet.net>. Acesso em: Abr 2016.

${ }^{27}$ Disponível em: <http://www.icmbio.gov.br/portal/comunicacao/noticias/20-geral/3522-criada-rede-nacional-de-ucurbanas.html>. Acesso em: Abr 2016. 
Nesse contexto, observa-se um aumento nos estudos sobre UCs urbanas do país nos últimos anos (mostrados em: MENEZES; MENDES, 2001; DEBETIR, 2006; RAMOS, 2007; BALOTTA; BITAR, 2009; MELLO-THÉRI; CORREIA, 2009; ARCE et al., 2014; PELLIN et al., 2014; GUIMARÃES; PELLIN, 2015). Dentre os estudos, destaca-se a iniciativa em se realizar um diagnóstico preliminar sobre as UCs urbanas federais do país, realizado em 2013 por von Behr e Peixoto (2013). Desse levantamento, verificou-se que das 320 UCs administradas pelo ICMbio (com exceção das RPPNs), 69 (22\%) podem ser consideradas urbanas e peri-urbanas.

Mais recentemente, Guimarães e Pellin (2015) realizaram uma análise sobre os principais desafios para a gestão de quatro UCs, as quais estão sendo pressionadas e ameaçadas pela urbanização, tais como: Parque Estadual da Pedra Branca (Rio de Janeiro), Reserva Biológica Estadual de Guaratiba (Rio de Janeiro), Parque São Bartolomeu (Salvador) e Parque Natural Municipal Fazenda do Carmo (São Paulo). Desse modo, observa-se que ainda são poucos os estudos na área de UCs urbanas no país, comparado com UCs localizadas em áreas mais remotas. Conforme ressaltado por Pellin et al. (2014), a criação de políticas públicas voltadas para a valorização e fortalecimento das UCs urbanas, torna-se urgente, visto que o país se torna cada dia mais urbano.

\section{Principais Pressões, Ameaças e Desafios Enfrentados pelas Unidades De Conservação Urbanas}

As áreas protegidas vêm sendo reconhecidas pelos países signatários da CDB como importantes elementos contra os impactos das mudanças globais (WORBOYS et al., 2015), visto que desempenham importantes funções contra a perda da biodiversidade e oferecem inúmeros benefícios para os ecossistemas e para as populações (STOLTON et al., 2015; WORBOYS et al., 2015). No entanto, a qualidade de muitas dessas áreas encontra-se em declínio, visto que estão constantemente cercadas pelos mais diversos problemas, os quais comprometem os seus objetivos de conservação (CAREY; DUDLEY; STOLTON, 2000; MATHUR; ONIAL; MAUVAIS, 2015).

Em relação aos problemas que afetam direta ou indiretamente as áreas protegidas, observase diversos esforços para listar as pressões e ameaças mais comuns para estes locais, tais como nos trabalhos de Terborgh et al. (2002), Ervin (2003), Atmiş, Özden, Lise (2007), McDonald et al., (2009), Nchor e Ogogo (2012) e mais recentemente em Fontoura, Medeiros, Adams (2016). 
Também se observam iniciativas para desenvolver classificações padrões para as pressões e ameaças que afetam o atual status da biodiversidade e para as ações de conservação que visam a sua mitigação (SALAFSKY et al., 2008). Desse modo, reconhecendo a necessidade de se desenvolver uma classificação global padronizada, Salafsky et al. (2008) propõem uma abrangente e flexível para ser utilizada na área da conservação. A classificação é feita de maneira hierárquica, onde as ameaças são classificadas em três níveis (figura 5).

Figura 5. Exemplo da classificação de ameaças proposta por Salafsky et al. (2008), dividida em três níveis hierárquicos.

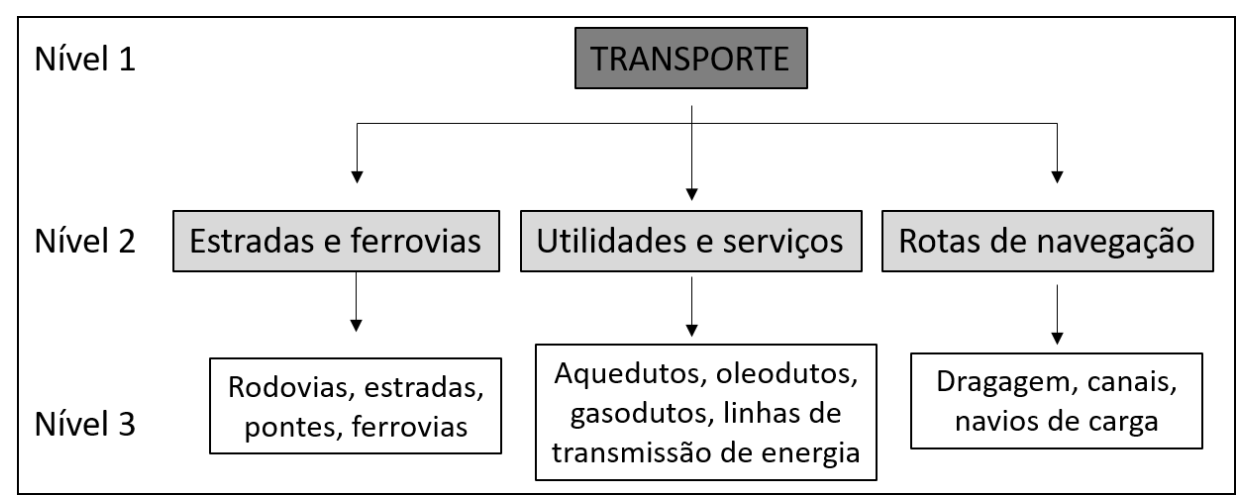

Fonte: Mathur, Onial e Mauvais (2015, p. 476, tradução nossa).

Nesse contexto, a IUCN utiliza uma classificação própria e específica para as principais pressões e ameaças em áreas protegidas, bem como discute sobre as consequências pontenciais dessas pressões e ameaças. Essa classificação foi criada por Worboys et al. (2006) e adaptada por Mathur, Onial e Mauvais (2015). Apesar desta classificação não utilizar a mesma organização de Salafsky et al. (2008), ela apresenta uma abordagem conceitual muito semelhante a dos autores e classifica as ameaças como diretas ou indiretas (MATHUR; ONIAL; MAUVAIS, 2015). O quadro 2 mostra alguns exemplos das principais ameaças (classificadas como diretas e indiretas) e suas consequências potenciais para áreas protegidas. 
Quadro 2. Exemplos das principais ameaças (diretas e indiretas) e suas consequências potenciais para áreas protegidas, proposta pela IUCN.

\begin{tabular}{|c|c|c|}
\hline \multicolumn{2}{|r|}{ AMEAÇAS } & CONSEQUÊNCIAS POTENCIAIS \\
\hline \multirow{11}{*}{ DIRETAS } & $\begin{array}{l}\text { Poluição local, impacto de produtos } \\
\text { químicos }\end{array}$ & $\begin{array}{l}\text { Danos aos ecossistemas naturais e espécies, aos valores } \\
\text { turísticos e recreativos e a saúde da população. }\end{array}$ \\
\hline & $\begin{array}{l}\text { Represamento/desvio de córregos e } \\
\text { rios, retirada de águas subterrâneas }\end{array}$ & $\begin{array}{l}\text { Danos aos ecossistemas naturais e espécies, bloqueio de } \\
\text { passagens de migração. }\end{array}$ \\
\hline & Pecuária & $\begin{array}{l}\text { Danos aos ecossistemas naturais e espécies, aos valores } \\
\text { turísticos e recreativos. }\end{array}$ \\
\hline & Mineração & $\begin{array}{l}\text { Danos aos ecossistemas naturais e espécies, aos valores } \\
\text { turísticos e recreativos e ao patrimônio cultural. }\end{array}$ \\
\hline & $\begin{array}{l}\text { Infraestrutura e desenvolvimento } \\
\text { industrial dentro da área protegida }\end{array}$ & $\begin{array}{l}\text { Danos aos ecossistemas naturais e espécies, ao patrimônio } \\
\text { cultural. }\end{array}$ \\
\hline & Turismo insustentável & $\begin{array}{l}\text { Danos aos ecossistemas naturais e espécies, ao patrimônio } \\
\text { social e cultural. }\end{array}$ \\
\hline & $\begin{array}{l}\text { Extração de recursos, incluindo a } \\
\text { caça, pesca (legal e ilegal) e } \\
\text { extração de madeira (legal e ilegal) }\end{array}$ & $\begin{array}{l}\text { Danos aos ecossistemas naturais e espécies, ao patrimônio } \\
\text { cultural, aos valores turísticos e recreativos. }\end{array}$ \\
\hline & Guerra e conflitos civis & $\begin{array}{l}\text { Danos aos ecossistemas naturais e espécies, ao patrimônio } \\
\text { social e cultural, à infraestrutura e à vida humana. }\end{array}$ \\
\hline & $\begin{array}{l}\text { Ações de gestão, processos e } \\
\text { recursos inadequados }\end{array}$ & $\begin{array}{l}\text { Danos aos ecossistemas naturais e espécies, ao patrimônio } \\
\text { social e cultural, à infraestrutura e vida humana. }\end{array}$ \\
\hline & $\begin{array}{l}\text { Espécies invasoras de plantas e } \\
\text { animais }\end{array}$ & Danos aos ecossistemas naturais e espécies. \\
\hline & $\begin{array}{l}\text { Eventos naturais catastróficos locais } \\
\text { (e.g. incêndios, inundações, } \\
\text { terremotos e atividades vulcânicas) }\end{array}$ & $\begin{array}{l}\text { Danos aos ecossistemas naturais e espécies, à } \\
\text { infraestrutura, propriedade e à vida humana. }\end{array}$ \\
\hline \multirow{4}{*}{ INDIRETAS } & Poluição externa & $\begin{array}{l}\text { Água poluída afetando ecossistemas marinhos e terrestres, } \\
\text { bem como espécies em áreas protegidas. Ar poluído } \\
\text { afetando ecossistemas e espécies. }\end{array}$ \\
\hline & $\begin{array}{l}\text { Represamento externo/ desvio de } \\
\text { córregos e rios, retirada de águas } \\
\text { subterrâneas }\end{array}$ & $\begin{array}{l}\text { Recursos hídricos inadequados ou interrupção de } \\
\text { deposição hidrológica, de solo e de nutrientes para a vida } \\
\text { selvagem em áreas protegidas, bloqueio das passagens de } \\
\text { migração, danos aos ecossistemas naturais. }\end{array}$ \\
\hline & Uso do solo/mar inapropriado & $\begin{array}{l}\text { Mudanças no uso do solo, perda de habitat e } \\
\text { fragmentação devido aos assentamentos humanos, } \\
\text { desenvolvimento urbano, agricultura e extração de } \\
\text { recursos. }\end{array}$ \\
\hline & Mudanças climáticas & $\begin{array}{l}\text { Mudanças na distribuição e abundância de espécies e } \\
\text { habitats, aumento do risco de extinção de espécies. } \\
\text { Mudanças nas chuvas, regimes e fluxos dos cursos d'água, } \\
\text { nos padrões de inundações, distribuição de gelo, } \\
\text { frequência e severidade de tempestades e incêndios, } \\
\text { climas extremos. } \\
\text { Inundação de áreas baixas devido à elevação do nível do } \\
\text { mar, impactos sobre os corais, branqueamento de corais }\end{array}$ \\
\hline
\end{tabular}

Fonte: Elaborado pela autora, a partir de Mathur, Onial e Mauvais (2015, tradução nossa).

Logo, a classificação proposta pela IUCN busca auxiliar as equipes de gestão e demais responsáveis pelas áreas protegidas a identificar as principais pressões e ameaças que 
compromentem a integridade desses locais e a compreender como estas podem ser mitigadas (MATHUR; ONIAL; MAUVAIS, 2015).

Nesse contexto, Ervin (2003) também descreve uma série de pressões e ameaças, propostas a serem identificadas pela metodologia RAPPAM, ilustradas no quadro 3.

Quadro 3. Exemplos de pressões e ameaças em UCs, propostas por Ervin (2003).

\begin{tabular}{|l|}
\hline \multicolumn{1}{|c|}{ PRESSÕES E AMEAÇAS EM UCS } \\
\hline Extrativismo de madeira (legal e ilegal); \\
\hline $\begin{array}{l}\text { Conversão do uso do solo (e.g. transformação de terras protegidas em moradia, assentamentos, estradas, agricultura, } \\
\text { reflorestamento, e outros usos de não proteção); }\end{array}$ \\
\hline $\begin{array}{l}\text { Mineração (e.g. todas as formas de escavação, mineração e exploração de recursos subterrâneos e também os resíduos } \\
\text { produzidos por tais atividades); }\end{array}$ \\
\hline Pastagem (e.g. pastoreio e coleta de forragem); \\
\hline Construção de barragens (e.g. para recreação, pesca, água potável e a geração de energia hidroelétrica); \\
\hline $\begin{array}{l}\text { Caça (inclui práticas de caça legais, que ameaçam os recursos da unidade de conservação, caça e pesca para comércio } \\
\text { ilegal e caça de subsistência); }\end{array}$ \\
\hline $\begin{array}{l}\text { Coleta de produtos não madeireiros (abrange a coleta de produtos não madeireiros para comercialização ou } \\
\text { subsistência, tais como alimentos, plantas medicinais, material de construção, resinas e outros recursos); }\end{array}$ \\
\hline $\begin{array}{l}\text { Turismo e recreação (inclui trilhas, acampamentos, passeios a cavalo, passeios de barco, uso de veículos motorizados } \\
\text { e outros tipos de recreação); }\end{array}$ \\
\hline $\begin{array}{l}\text { Disposição de resíduos - inclui qualquer forma inadequada de disposição de resíduos de atividades legais (e.g. } \\
\text { combustível e embalagens de alimentos de turistas), bem como de atividades ilegais (e.g. produção de } \\
\text { metanfetamina, e despejo de materiais tóxicos); }\end{array}$ \\
\hline $\begin{array}{l}\text { Processos seminaturais (incluem processos naturais que foram magnificados pela intervenção antrópica, tais como } \\
\text { incêndios catastróficos, ou explosões de insetos, provocadas pela supressão prolongada); }\end{array}$ \\
\hline $\begin{array}{l}\text { Influências transfronteiriças - inclui a poluição local e regional e a acidificação, o aumento do escoamento de águas, } \\
\text { resíduos de nitrogênio, e as inundações decorrentes das práticas de manejo e do uso do solo nas áreas vizinhas; } \\
\text { flutuações no tempo devido a mudanças climáticas globais; }\end{array}$ \\
\hline $\begin{array}{l}\text { Espécies exóticas invasoras - abrange as plantas e os animais introduzidos intencionalmente ou inadvertidamente por } \\
\text { humanos (e.g. truta, minhoca, mexilhões-zebra). }\end{array}$ \\
\hline
\end{tabular}

Fonte: Elaborada pela autora (2016), a partir de Ervin (2003).

Verifica-se que todas as áreas protegidas podem estar sujeitas às pressões e ameaças descritas anteriormente (MATHUR; ONIAL; MAUVAIS, 2015). No entando, observa-se que as áreas protegidas urbanas, por estarem localizadas próximas ou inseridas na matriz urbana, sofrem influências diretas da ocupação humana, estando mais sujeitas as mesmas ou a outros tipos de ameaças (GUIMARÃES; PELLIN, 2015). Nesse sentido, Trzyna (2014) caracteriza determinadas áreas protegidas localizadas em regiões metropolitanas de regiões, climas e situações 
socioeconômicas diversas, bem como relata sobre as pressões e ameaças mais comuns que afetam essas áreas ${ }^{28}$. A partir das análises do autor, as pressões e ameaças urbanas verificadas como mais comuns em UCs urbanas foram listadas (quadro 4).

Quadro 4. Principais pressões e ameaças que afetam UCs urbanas, propostas por Trzyna (2014).

\begin{tabular}{|l|}
\hline \multicolumn{1}{|c|}{ PRINCIPAIS PRESSÕES E AMEAÇAS EM UCS URBANAS } \\
\hline Poluição local e/ou externa: atmosférica, dos recursos hídricos, sonora e visual \\
\hline Infraestrutura (e.g. linhas de transmissão de energia, estradas, ferrovias e/ou portos) e desenvolvimento industrial \\
\hline Turismo e recreação insustentável \\
\hline Extração de recursos florestais não-madeireiros e madeireiros; caça e pesca \\
\hline Espécies exóticas invasoras \\
\hline Eventos catastróficos seminaturais (e.g. incêndios e inundações) \\
\hline Ocupações ilegais (dentro e/ou no entorno da unidade) \\
\hline Mudanças climáticas \\
\hline Desenvolvimento urbano do entorno \\
\hline Disposição de resíduos (e.g. embalagens de alimentos de turistas e entulho) \\
\hline Conflitos entre humanos e animais selvagens \\
\hline Crimes (e.g. vandalismo, contrabando, uso e tráfico de drogas) \\
\hline
\end{tabular}

Fonte: Elaborada pela autora (2016), a partir de Trzyna (2014).

De acordo com Trzyna (2014), as pressões e ameaças frequentes às áreas protegidas urbanas são oriundas do intenso processo de urbanização e podem trazer impactos permanentes e de grande magnitude. Nesse sentido, a qualidade dos recursos naturais, presentes nas áreas protegidas urbanas pode estar comprometida por atividades que não são acompanhadas de tratamentos adequados (TRZYNA, 2014).

Em relação à poluição dos recursos hídricos, McDonald et al. (2009) alegam que existem efeitos negativos para as áreas protegidas quando estão localizadas na mesma bacia hidrográfica

\footnotetext{
${ }^{28}$ Royal National Park (Sydney, Australia), Parque Nacional da Tijuca (Rio de Janeiro, Brasil), Parque Estadual da Cantareira (São Paulo, Brasil), Hong Kong Country Parks (Hong Kong, China), Yangmingshan National Park (Taipei, Taiwan), Calanques National Park (Marseille, França), Sanjay Gandhi National Park (Mumbai, India), Blue and John Crow Mountains National Park (Kingston, Jamaica), Nairobi National Park (Nairobi, Kenya), Bukhansan National Park (Seoul, Korea), Mudeungsan National Park (Gwangju, Korea), Table Mountain National Park (Cidade do Cabo, África do Sul), London Wetland Centre (Londres, Reino Unido), Santa Monica Mountains National Recreation Area and PAs in the San Gabriel Mountains (Los Angeles, California), Golden Gate National Recreation Area (São Francisco, California).
} 
que áreas urbanas. Como por exemplo, Trzyna (2014) evidencia essa ameaça citando o Royal National Park (localizado em Sydney, Austrália), uma área protegida que tem sido impactada pelo despejo de poluentes proveniente de fora de suas fronteiras.

De maneira similar, as áreas urbanas concentram grande parte da produção e consumo da economia global, sendo responsáveis pelo aumento dos gases do efeito estufa na atmosfera (MCDONALD, 2008), os quais podem trazer graves consequências para as áreas protegidas (MCDONALD et al., 2009). Desse modo, alguns estudos vêm mostrando os impactos oriundos da emissão de poluentes às áreas protegidas, provenientes de atividades antrópicas (RIDDELL, 2002; DESJARDINS et al., 2004; TRZYNA, 2014).

Outros tipos de pressões e ameaças que vêm sendo observadas em áreas protegidas urbanas são as poluições sonoras e a visuais, as quais podem afetar diretamente a sobrevivência de algumas espécies (e.g. reprodução, alimentação e migração). De acordo com Trzyna (2014), as áreas protegidas urbanas são especialmente mais vulneráveis para esses problemas, visto que estão localizadas mais próximas de assentamentos humanos. Segundo o autor, elas podem ocorrer devido diversos fatores, tais como pela presença de visitantes, atividades industriais e tráfico de veículos nas proximidades de uma área protegida.

Nesse sentido, observa-se uma clara tendência global na diminuição da distância de uma área protegida para uma área urbana mais próxima (MCDONALD et al., 2009). As previsões mostram um mundo mais urbanizado e populoso, aumentando consequentemente a demanda por diversos tipos de infraestruturas (e.g. LTs, estradas, ferrovias) que atendam às necessidades da população (BARBER et al., 2004; WATSON et al., 2014; CUMMING, 2016). Consequentemente, é esperado que haja uma grande pressão dos diferentes setores da economia sobre a utilização dos recursos, em favor da proteção e conservação dos mesmos, bem como uma diminuição no suporte das áreas protegidas, em favor de forças que defendam a sua utilização (WORBOYS, 2015). Desse modo, verifica-se que áreas naturais localizadas próximas desses tipos de infraestruturas podem sofrer impactos graves, dentre eles, a perda de sua biodiversidade. Trzyna (2014) evidencia esse fato com o Nairobi National Park (Quênia), o qual teve sua zona de amortecimento (ZA) invadida por fábricas e assentamentos humanos ilegais. 
Uma das características das áreas protegidas urbanas é o seu potencial para a realização de atividades de uso público, sejam elas para fins turísticos ou recreativos ${ }^{29}$ (MEDEIROS et al., 2011; RODRIGUES, 2009). Além de proporcionarem uma série de benefícios para a saúde da população, elas também apresentam um grande potencial econômico, gerando renda para as economias locais (MEDEIROS et al., 2011; TRZYNA, 2014). Contudo, quando ultrapassam a sua capacidade de suporte para o recebimento de visitantes, tais atividades podem trazer impactos negativos para as áreas protegidas, sendo consideradas como pressões e ameaças (BUCKLEY, 2004). Desse modo, observa-se que grande parte das UCs urbanas vêm sofrendo com o turismo e recreação, atividades que podem trazer sérios danos, fato destacado por Tryzna (2014) em treze de quinze casos de estudos analisados.

Com a urbanização e o aumento do crescimento populacional, as ocupações ilegais, dentro e/ou no entorno das áreas protegidas urbanas são consideradas grandes pressões e ameaças para os gestores, pois colaboram com a perda da qualidade ambiental da área (TRZYNA, 2014). Algumas empresas do setor imobiliário se aproveitam do status "verde" ao venderem imóveis próximos às áreas protegidas, a exemplo o Parque Estadual da Cantareira (localizado em São Paulo) (MELLOTHÉRY, 2009). Não somente a classe alta, mas também moradias de classes mais baixas podem ser observadas em áreas mais afastadas e menos estruturadas (MELLO-THÉRY, 2009). Os impactos para essas áreas são diversos, tais como: supressão vegetal, lançamento de esgoto sem tratamento, aumento do risco de incêndios e espécies exóticas invasoras (MENEZES; MENDES, 2001; TRZYNA, 2014). Contudo, cabe observar que as UCs da categoria de proteção integral não permitem a ocupação humana em seu interior (BRASIL, 2000). Assim, muitas áreas protegidas urbanas vêm sendo alvos de ocupações ilegais, tais como o Parque Nacional Delta do Jacuí (Rio Grande do Sul), localizado próximo do centro urbano de Porto Alegre e pressionado pela formação de moradias irregulares do entorno (CARDOSO, 2006).

A proximidade dos assentamentos humanos com as áreas protegidas urbanas pode resultar em conflitos entre humanos e animais selvagens, configurando-se também como pressões e ameaças para esses locais. Segundo Trzyna (2014), os conflitos ocorrem quando espécies da fauna ultrapassam os limites dessas áreas, indo em direção às cidades. Dentre os conflitos, destacam-se

\footnotetext{
${ }^{29}$ A visitação pública varia conforme a categoria de manejo da área protegida e está sujeita às normas e restrições estabelecidas no seu plano de manejo.
} 
os atropelamentos de animais, dispersão de lixos, destruição de jardins, residências e a caça desses animais (TRZYNA, 2014).

Outro problema observado, fruto das atividades humanas dentro e/ou no entorno das áreas protegidas urbanas é a disposição irregular de resíduos por parte da população residente e/ou visitantes (e.g. embalagens de alimentos, entulhos e escoamento de esgoto não tratado) (TRZYNA, 2014). Esse mal comportamento pode trazer grandes danos aos ecossistemas e espécies, visto que esses resíduos podem permanecer por anos no ambiente, trazer graves consequências para as diversas espécies de animais que acabam por se alimentar dos resíduos expostos, bem como transmitir doenças (TRZYNA, 2014).

Outra questão comum é a ocorrência de crimes dentro das áreas protegidas urbanas, tais como assalto aos visitantes, uso e tráfico de drogas, atos de vandalismo e ocultação de cadáveres (MCDONALD et al., 2009; TRZYNA, 2014). Essas áreas podem se tornar palco de práticas ilegais, muitas vezes devido ao seu rápido acesso e por oferecer fáceis áreas para esconderijos (TRZYNA, 2014). Como consequência, a falta de segurança passa a ser um fator determinante para o afastamento da população da cidade, resultando no abandono da área (TRZYNA, 2014). Um exemplo típico pode ser observado no Parque Natural Municipal Fazenda do Carmo, localizado em São Paulo, uma área protegida urbana afetada pelo histórico de violência da região (GUIMARÃES; PELLIN, 2015).

A prática de extrativismo e o desmatamento também são considerados pressões e ameaças para as áreas protegidas urbanas (TRZYNA, 2014). A extração de recursos florestais nãomadeireiros pode ocorrer para fins alimentícios, usos medicinais, materiais de construção, comércio, subsistência, entre outros (ERVIN, 2003). Já em relação aos recursos madeireiros, observa-se o seu uso para a produção de carvão e lenha nos países em desenvolvimento, ao passo que nos países mais desenvolvidos, para acampamentos durante atividades recreativas (MCDONALD et al., 2009). No Brasil, Guimarães e Pellin (2015) evidenciam um caso típico de práticas extrativistas no Parque São Bartolomeu, uma UC urbana localizada no município de Salvador, reconhecida como um importante sítio sagrado para os moradores do entorno. Além desses usos conflitantes, a caça e a pesca ilegal também são reconhecidas como pressões e ameaças, isto é, atividades incompatíveis com os objetivos das áreas protegidas urbanas, as quais vêm acentuando o fenômeno de defaunação e podendo trazer impactos negativos para os ecossistemas (GUIMARÃES; PELLIN, 2015). 
A fragmentação de habitats é resultado de frequentes alterações da paisagem, transformando habitats naturais em manchas isoladas de diferentes tamanhos (SAUNDERS; HOBBS; MARGULES, 1991). O processo de fragmentação e as mudanças dos usos dos solos são acentuados nas áreas urbanas, podendo transformar grandes áreas em remanescentes de vegetação nativa isolados (CERQUEIRA et al., 2003). Assim, o tamanho, a distância e a forma dos fragmentos, bem como o efeito de borda originado do processo de fragmentação acarretam em inúmeros prejuízos para os ecossistemas existentes, destacando-se a perda da biodiversidade (SAUNDERS; HOBBS; MARGULES, 1991).

Desse modo, um dos resultados observados na paisagem modificada é a introdução e dispersão de espécies exóticas invasoras (e.g. braquiária - Brachiaria mutica, mamona -Ricinus communis, gatos - Felis catus e cachorros - Canis lupus), sendo um problema bastante comum em grande parte das áreas protegidas urbanas (TRZYNA, 2014). As espécies exóticas são conhecidas por se estabelecerem em regiões diferentes da sua distribuição natural (CBD, 2008). Já as espécies invasoras são aquelas que após estabelecidas, expandem a sua distribuição, ameaçando os ecossistemas, habitats e espécies nativas, visto que são capazes de alterar ciclos ecológicos naturais (CBD, 2008) e afetar os serviços ecossistêmicos vitais para o bem-estar humano (CORVALAN; HALES; MCMICHAEL, 2005). Nesse sentido, a introdução dessas espécies pode ocorrer intencionalmente ou inadvertidamente por ações humanas, como por exemplo através de portos fluviais e marítimos, aeroportos, estações rodoviárias e ferroviárias, jardins e viveiros de plantas (TRZYNA, 2014), sendo consideradas uma das maiores causas de perda da biodiversidade no mundo (WILCOVE et al., 1998; WORBOYS et al., 2015)

Outros tipos de pressões e ameaças são os eventos catastróficos seminaturais, isto é, eventos que são ampliados pela intervenção humana (e.g. incêndios e inundações). Desse modo, observase que o uso do solo urbano pode aumentar a origem de incêndios dentro e/ou no entorno de áreas protegidas urbanas (MCDONALD et al., 2009). Como exemplo, verifica-se como causas de incêndios do Parque Estadual da Pedra Branca (localizado no Rio de Janeiro) limpezas de terrenos através de queimadas no seu entorno, quedas de balões, queimas de lixo e práticas de rituais religiosos com a utilização de materiais inflamáveis (GUIMARÃES; PELLIN, 2015). Os incêndios em áreas protegidas podem causar perdas irreparáveis, tais como: piora na qualidade do ar, perda de biodiversidade da fauna e flora e de recursos genéticos e redução dos serviços ecossistêmicos (SILVA, 2001; MEDEIROS, 2002). 
Nas últimas décadas, as mudanças climáticas vêm sendo reconhecidas como uma das mais graves ameaças para o planeta Terra, devido as alterações nas temperaturas, padrões de precipitações, níveis do mar e ecossistemas (BELLARD et al., 2012). Desse modo, as mudanças climáticas também se figuram como pressões e ameaças para as áreas protegidas urbanas, fato evidenciado no Parque Nacional Table Mountain, localizado na Cidade do Cabo (África do Sul). Segundo Trzyna (2014), a região torna-se a cada ano mais quente e seca, aumentando significativamente os riscos de incêndios e o estresse hídrico. Além disso, já é possível observar as alterações nos ciclos de vidas de plantas nativas, bem como o aumento da dispersão de espécies exóticas invasoras (TRZYNA, 2014).

Carey, Dudley e Stolton (2000) definiram as principais causas da existência de ameaças para as áreas protegidas. A primeira causa se deve ao elevado nível de consumo do 1/5 da população mundial mais rica. Esse alto consumo estimula o setor agroindustrial, o turismo, a extração de madeira e atividades de mineração, as quais por sua vez impactam as áreas protegidas e o solo em torno delas. A segunda causa é pelo comércio e busca por desenvolvimento, as quais ignoram as implicações ambientais das políticas de desenvolvimento. Segundo esses autores, muitas vezes, essas pressões são impulsionadas pelo elevado consumo, ou também pela necessidade do pagamento de dívidas em muitos países em desenvolvimento. A terceira principal causa é a pobreza entre a população dos países não desenvolvido, a qual frequentemente utiliza a terra e os recursos para subsistência, levando a um aumento da pressão nas unidades.

Além das pressões e ameaças típicas que dificultam a conservação desses espaços, ainda existem uma série de desafios a serem superados tanto para as áreas urbanas como para as demais (GUIMARÃES; PELLIN, 2015). Em especial ao modelo brasileiro de áreas protegidas, verificase algumas dificuldades na gestão de determinadas UCs, certamente pela falta de infraestrutura, recursos financeiros e profissionais capacitados (observados nos estudos de: AUER, 1995; LIMA et al., 2005; FARIA, 2006; LEMOS DE SÁ; FERREIRA, 2000; BORGES et al., 2007; AGUIARSILVA et al 2010; SCHIAVETTI et al., 2012; GUIMARÃES; PELLIN, 2015; PUREZA; PELLIN; PADUA, 2015). Além disso, a ausência de regularização fundiária é uma realidade de grande parte das áreas protegidas do país, as quais foram estabelecidas em meio a sérias pendências fundiárias, acentuando-se com o passar dos anos (ROCHA; DRUMMOND; GANEM, 2010).

Outro problema observado é a falta de planos de manejo e a sua implementação (MILANO, 2000), visto que este estabelece as diretrizes para uma gestão adequada nas UCs (LEMOS DE SÁ; 
FERREIRA, 2000), tornando-se difícil a gestão dessas áreas na sua ausência. Além disso, Pureza, Pellin e Pádua (2015) afirmam que as prioridades na gestão das UCs do país variam conforme os governantes do momento, não seguindo um plano ambiental de longo prazo. Para piorar, verificase a difícil articulação institucional para que as UCs sejam implementadas e geridas, além da falta de significativa compreensão por parte de grande parcela da sociedade sobre a vital relação entre conservação ambiental e qualidade de vida (MMA, 2015a). Desse modo, verifica-se que a ausência de recursos financeiros, de capacidade de gestão pública, de participação social, e de políticas públicas agravam a conservação e manutenção dessas áreas (PUREZA; PELLIN; PÁDUA, 2015).

Visto que as diversas áreas protegidas urbanas são impactadas pelo contexto global de urbanização da atualidade, compreender as pressões e as ameaças, suas causas e impactos para esses locais constituem uma etapa primordial do processo para erradicá-las, bem como para que continuem exercendo os seus objetivos de conservação e de integração da população urbana com o ambiente natural. 


\section{CAPÍTULO II. UNIDADES DE CONSERVAÇÃO URBANAS DO ESTADO DE SÃO PAULO}

\section{Introdução}

O Brasil, país com mega biodiversidade (FONSECA; PINTO; RYLANDS, 1997), possui o compromisso de proteger importantes biomas, tais como a Amazônia, Caatinga, Cerrado, Mata Atlântica, Pampa e Pantanal (RYLANDS; BRANDON, 2005). Segundo Rylands e Brandon (2005), para que o país consiga cumprir com este compromisso, é fundamental a criação e implementação de UCs.

De acordo com o Cadastro Nacional de Unidades de Conservação (CNUC, 2016) ${ }^{30}$, o país possui $2.029 \mathrm{UCs}$, representando $1.544 .833 \mathrm{~km}^{2}$ de superfície territorial legalmente protegida. Deste total, 636 pertencem a categoria de proteção integral (cerca de 541.296 km²). Em 1997, existiam apenas 670 UCs de todas as categorias, e deste número, 444 UCs de proteção integral (FONSECA; PINTO; RYLANDS, 1997). Desse modo, houve um ganho expressivo de território protegido durante esses 20 anos, processo facilitado pela implantação gradativa do SNUC. Contudo, essas áreas não estão distribuídas igualmente pelos diferentes biomas brasileiros ${ }^{31}$, sendo um dos grandes desafios para se atingir uma das Metas Nacionais de Biodiversidade para 2020 garantir a representatividade nos diferentes biomas.

O Estado de São Paulo é formado praticamente por dois biomas, o Cerrado e a Mata Atlântica (BIOTA FAPESP, 2017), considerados dois hotspots de biodiversidade (RYLANDS; BRANDON, 2005). De acordo com o CNUC ${ }^{32}$ (2016), existem 266 UCs no Estado de São Paulo, sendo que 96 pertencem à categoria de proteção integral e 130 pertencem à categoria de uso sustentável. O responsável pela gestão ambiental no território do Estado de São Paulo é o Sistema Ambiental Paulista, composto por coordenadorias, institutos, fundações, Companhia Ambiental do Estado de São Paulo (CETESB) e Polícia Militar Ambiental, sendo a Secretaria do Meio Ambiente o órgão central (SISTEMA AMBIENTAL PAULISTA, 2017).

Localizado na região sudeste do país, o Estado de São Paulo é o mais industrializado e urbanizado do país. De acordo com os dados disponibilizados pelo Governo do Estado (2017), é a terceira unidade administrativa mais populosa da América do Sul, apresentando a maior população

\footnotetext{
${ }^{30}$ Dados atualizados em 09 de agosto de 2016.

${ }^{31}$ Como por exemplo, atualmente o bioma Pampa apresenta apenas $2,7 \%$ do seu território protegido, ao passo que a Mata Atlântica possui aproximadamente 9,2\% (CNUC, 2016).

${ }^{32}$ Dados atualizados em 09 de agosto de 2016.
} 
dentre os Estados do Brasil, com mais de 43 milhões de habitantes distribuídos em 645 municípios. Também é o Estado responsável por $28,7 \%$ do PIB do país, sendo considerado o "motor econômico" do Brasil por abrigar o maior parque industrial e a maior produção econômica (GOVERNO DO ESTADO DE SÃO PAULO, 2017). Além disso, abriga a Região Metropolitana de São Paulo (RMSP), o maior polo de riqueza nacional, possuindo cerca de $50 \%$ da população estadual (GOVERNO DO ESTADO DE SÃO PAULO, 2017).

Frente ao cenário urbano paulista, verifica-se que as UCs são fortemente influenciadas pelas atividades antrópicas de suas vizinhanças (GUIMARÃES; PELLIN, 2015), podendo apresentar os mesmos ou também novos desafios de gestão (COSTA et al., 2007; GUIMARÃES; PELLIN, 2015). Alguns autores (OLIVA; MAGRO, 2004; COSTA et al., 2007) discutem sobre a ausência de diagnósticos e ações específicas sistematizadas das equipes de gestão das UCs brasileiras, que levem em consideração as interfaces com os seus entornos. Dado esses fatos, torna-se importante repensar sobre os modelos atuais de gestão e sobre como as UCs urbanas, em especial as de proteção integral, vêm adotando ações de conservação para a mitigação de suas principais pressões e ameaças.

É nesse contexto que se insere o presente capítulo. Aqui são apresentados quatro casos de estudos, referentes a determinadas UCs urbanas, da categoria de proteção integral, localizadas no Estado de São Paulo. Todas essas áreas se assemelham por estarem localizadas próximas ou inseridas em áreas urbanas, sobre as quais se avança o desenvolvimento das cidades.

De maneira geral, primeiramente é feita uma breve descrição do contexto de cada área, com o objetivo de apresentar as suas características mais importantes. Em seguida, as principais pressões e ameaças identificadas nas entrevistas pelas equipes de gestão são descritas e avaliadas, de acordo com um grau de severidade, definida por Ervin (2003). A partir disso, é possível indicar as prioridades de conservação para aquelas atividades que vêm resultando em impactos prejudiciais à integridade das UCs. Após essa etapa, são discutidas as principais ações de conservação que vêm sendo adotadas pela gestão dessas UCs, com o propósito de mitigar os seus problemas.

\section{Materiais e Método}

- Seleção das UCs

O processo de seleção dos casos de estudo observou os critérios apresentados na figura 6. 
Figura 6. Delimitação do recorte da pesquisa, a partir de cinco critérios para seleção dos casos de estudos nacionais.

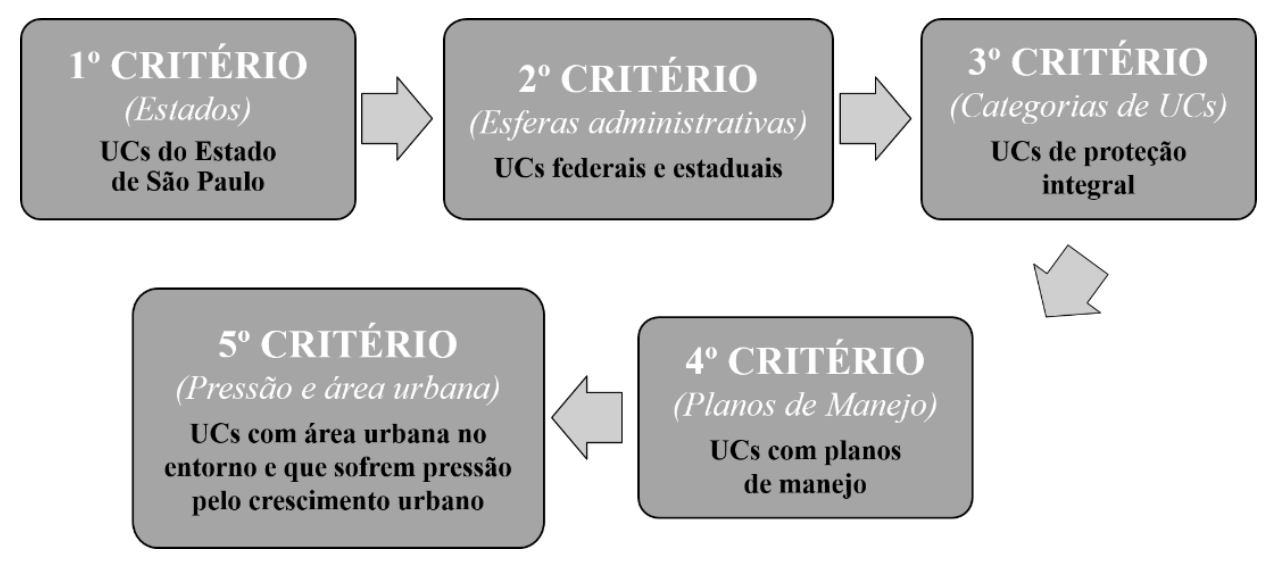

Fonte: Elaborado pela autora (2016).

Como primeiro critério, optou-se por áreas do Estado de São Paulo. A escolha por este Estado se deve aos seus altos índices de urbanização, produção econômica e crescimento populacional, conforme ressaltado na introdução. Segundo o levantamento de dados realizado em 2014 (início do desenvolvimento da pesquisa) pelo CNUC e atualizado em agosto de 2016, existem atualmente um total de 214 UCs no Estado de São Paulo (categorias de proteção integral e uso sustentável), se enquadrando no primeiro critério estabelecido.

Devido a abrangência de UCs do Estado de São Paulo, o segundo critério foi selecionar as UCs de acordo com a sua esfera administrativa. Das 214 UCs encontradas, verificou-se que 182 pertencem às esferas administrativas federais e estaduais, ao passo que 32 pertencem à esfera municipal. Optou-se pelas UCs federais e estaduais dado que estão em maior número se comparadas com as UCs municipais.

Como terceiro critério, optou-se por áreas pertencentes à categoria de proteção integral devido as suas restrições de uso, constituindo-se de maior relevância para a conservação da biodiversidade. Desse modo, segundo a classificação do SNUC, incluem-se nessas categorias as REBIOs, ESECs, PARNAs ou parques estaduais, MNs e REVIS. Verificou-se que, das 182 UCs estaduais e federais do Estado de São Paulo, 68 unidades pertencem a categoria de proteção integral, ao passo que 114 pertencem a categoria de uso sustentável. Das 68 UCs de proteção integral verificadas, uma se encontra em área marinha (Parque Estadual Marinho da Laje de Santos), sendo excluída da seleção. Desse modo, foram selecionadas 67 UCs de proteção integral do Estado de São Paulo, preenchendo o terceiro critério do estudo. 
Para o quarto critério, decidiu-se por áreas que possuíssem planos de manejo, principal instrumento que estabelece as diretrizes para uma gestão adequada (LEMOS DE SÁ; FERREIRA, 2000), pois entende-se que na sua ausência torna-se mais difícil adotar ações de conservação. Para identificar aquelas UCs com planos de manejo, foi realizado um levantamento através dos sites do CNUC, Instituto Florestal (IF) e Fundação para a Conservação e Produção Florestal do Estado de São Paulo (FF). Além disso, foram coletadas informações sobre as 67 UCs selecionadas (e.g. gestores responsáveis, endereço, telefone e e-mail para contato). Dado que os cadastros de muitas unidades estavam com informações desatualizadas, optou-se pelo envio de um questionário online $^{33}$ para os gestores, elaborado através da Plataforma Google Docs, com o intuito de selecionar as UCs que se enquadrassem nesse e demais critérios.

Para a execução de pesquisas de qualquer natureza em UCs geridas pela FF, é necessário solicitar uma permissão junto à Comissão Técnico-Científica do Instituto Florestal (COTEC) ${ }^{34}$. Após a solicitação, é emitida uma Carta de Aprovação, na qual consta que pesquisador está autorizado em realizar pesquisas científicas na UC solicitada. Desse modo, as permissões foram solicitadas e acompanhadas de Termos de Compromisso e Responsabilidade. As Cartas de Aprovação levaram em torno de 6 meses para serem liberadas.

Após o recebimento das permissões, foram enviados questionários para as 67 UCs que se enquadraram nos quatro primeiros critérios. Durante um período de 10 meses, entrou-se em contato com os gestores por telefone e e-mail a fim de informar sobre a intenção do questionário e sobre a importância da participação destes para a execução da pesquisa. No entanto, houve uma série de dificuldades enfrentadas nessa etapa, visto que muitos gestores não respondiam os questionários, e/ou não retornavam os telefonemas e e-mails, ou até mesmo os contatos disponibilizados nos sites oficiais não existiam. No final desse período, houve um retorno de 59 respostas dos 67 questionários enviados, as quais foram organizadas em uma planilha do programa Excel. Das 59 UCs que retornaram o contato, verificou-se que 28 apresentam planos de manejo, compondo o quarto critério da pesquisa.

O quinto critério foi escolher as UCs que estão inseridas ou localizadas próximas às áreas urbanas, assim como as que relatassem estarem sofrendo alguma pressão típica urbana. Logo, das

\footnotetext{
${ }^{33}$ Apêndice I.

${ }^{34}$ Nesta etapa, a COTEC submete o projeto de pesquisa para as UCs selecionadas e estas retornam à COTEC se autorizam ou não a realização da pesquisa. Além disso, o pesquisador deve seguir as orientações previstas na Carta de Aprovação emitida pelo gestor.
} 
28 UCs que possuem planos de manejo, observou-se que 12 UCs se enquadraram neste critério (quadro 5).

Quadro 5. UCs do Estado de São Paulo que se enquadraram nos cinco critérios de seleção.

\begin{tabular}{|c|c|}
\hline UCS URBANAS & LOCALIZAÇÃo \\
\hline Parque Estadual do Jaraguá (PEJ) & Osasco e São Paulo \\
\hline Parque Estadual da Cantareira (PEC) & São Paulo, Guarulhos, Mariporã e Caieiras \\
\hline Estação Ecológica de Ribeirão Preto (EERP) & Ribeirão Preto \\
\hline Parque Estadual Xixová-Japuí & Praia Grande e São Vicente \\
\hline Parque Estadual de Porto Ferreira & Porto Ferreira \\
\hline Parque Estadual do Jurupará & Ibiúna, Juquitiba, Miracatu, Piedade e Tapiraí \\
\hline Estação Ecológica de Santa Bárbara & Águas de Santa Bárbara \\
\hline Estação Ecológica de Itirapina & Itirapina e Brotas \\
\hline Estação Ecológica de Assis & Assis \\
\hline Parque Estadual das Fontes do Ipiranga & São Paulo \\
\hline Parque Nacional da Serra da Bocaina & Angra dos Reis (RJ), Areias, Bananal, Cunha, \\
& Parati (RJ), São José do Barreiro e Ubatuba \\
\hline Estação Ecológica do Noroeste Paulista & Mirassol e São José do Rio Preto \\
\hline
\end{tabular}

Fonte: Elaborado pela autora (2016).

Entrou-se em contato com as 12 UCs selecionadas para a realização de entrevistas semiestruturadas com as suas equipes de gestão, através dos contatos disponibilizados pelos sites do CNUC, FF e IF. Das 12 UCs selecionadas, 4 responderam de prontidão concordando em participar das entrevistas, 2 não retornaram o contato e 6 responderam mais tardiamente. Contudo, não foi possível entrevistar todas as 10 UCs devido ao período de tempo proposto para a realização da pesquisa e devido ao alto grau de detalhamento desejado das respostas, dando-se preferência às quatro primeiras UCs que responderam com maior facilidade (quadro 6).

Quadro 6. UCs participantes da pesquisa.

\begin{tabular}{|c|c|c|}
\hline ÓRGÃO GESTOR & UNIDADES DE CONSERVAÇÃO & LOCALIZAÇÃO \\
\hline \multirow{2}{*}{$\begin{array}{c}\text { Fundação para Conservação e } \\
\text { Produção Florestal do Estado de } \\
\text { São Paulo (FF) }\end{array}$} & Parque Estadual do Jaraguá (PEJ) & Osasco e São Paulo \\
\cline { 2 - 3 } & Parque Estadual da Cantareira (PEC) & $\begin{array}{c}\text { São Paulo, Guarulhos, } \\
\text { Mariporã e Caieiras }\end{array}$ \\
\cline { 2 - 3 } & Estação Ecológica de Ribeirão Preto (EERP) & Ribeirão Preto \\
\hline Instituto Florestal (IF) & Estação Ecológica de Assis (EEcA) & Assis \\
\hline
\end{tabular}

Fonte: Elaborado pela autora (2016). 


\section{- Entrevistas semiestruturadas}

As entrevistas semiestruturadas contemplam perguntas abertas e fechadas, com o intuito do entrevistado/a ter a possibilidade de discorrer mais profundamente sobre o tema. Além disso, foram realizadas perguntas adicionais para elucidar as questões que não ficaram totalmente esclarecidas, bem como obter informações mais precisas. Desse modo, o objetivo foi extrair informações provindas diretamente das equipes de gestão, e não apenas da literatura, buscando investigar as práticas de gestão realizadas.

As entrevistas foram realizadas pessoalmente com os gestores (com exceção da Estação Ecológica de Assis - EEcA, onde a entrevista foi realizada por vídeo conferência) e em alguns casos com a participação de membros da equipe de gestão. Infelizmente, não foi possível contar com a presença de toda a equipe, devido questões de tempo e logística. No entanto, foi orientado para os gestores e demais participantes que fornecessem respostas que contemplassem a situação atual da UC.

Primeiramente, foi elaborado um roteiro dirigido ${ }^{35}$, com perguntas fechadas e abertas, para guiar as entrevistas. Esse roteiro foi baseado no método RAPPAM ${ }^{36}$ (ERVIN, 2003), escolhido por ser reconhecido nacional e internacionalmente em trabalhos acadêmicos com UCs. Assim, o roteiro apresentou três seções, com objetivos distintos, detalhadas a seguir:

A primeira seção teve como objetivo obter uma visão geral sobre a realidade das UCs selecionadas (e.g. importância biológica, econômica e social), dividida em 4 tópicos: perfil, contexto, planejamento e recursos humanos (insumos).

A segunda seção foi uma lista de verificação (checklist) de pressões e ameaças comuns às UCs urbanas, onde as equipes de gestão tinham como objetivo identificá-las e avaliá-las de acordo com um grau de severidade. A partir dessa metodologia, é possível analisar as pressões que já estão trazendo um impacto prejudicial à UC, bem como aquelas que continuarão a trazer e/ou aquelas que provavelmente resultarão em novos impactos para os próximos anos. Logo, permite direcionar as prioridades de conservação para cada UC.

\footnotetext{
35 Apêndice II.

36 Apesar do roteiro dirigido ter sido baseado nas questões abordadas pelo RAPPAM, um método utilizado para avaliação de gestão de UCs, ressalta-se que não é objetivo do trabalho avaliar a gestão das UCs selecionadas. O RAPPAM serviu para dar um direcionamento nas questões. Logo, pretende-se dar um enfoque mais profundo nas respostas obtidas, analisando caso a caso de maneira específica e detalhada.
} 
Assim, para cada pressão e ameaça assinalada, as equipes de gestão informaram sobre a sua ocorrência, abrangência, impacto e permanência. Cada um desses itens avaliados recebeu uma pontuação (de 1 a 4), refletindo a intensidade da pressão/ameaça (ERVIN, 2003). Segundo Ervin (2003), a abrangência de uma pressão/ameaça é a extensão através do qual o impacto da atividade ocorre, podendo ocorrer em toda a área (4 pontos), ser disseminada (3 pontos), dispersa ( 2 pontos) ou localizada (1 ponto). Já o impacto, se refere ao nível, direto ou indiretamente, para o qual a pressão afeta os recursos da UC, podendo ser grave (4 pontos), alto (3 pontos), moderado (2 pontos) ou suave (1 ponto). Já a permanência é o intervalo de tempo que se faz necessário para que determinado recurso afetado se recupere, com ou sem a intervenção antrópica, podendo ser permanentes ( 4 pontos), a longo prazo ( 3 pontos), a médio prazo ( 2 pontos) ou a curto prazo ( 1 ponto).

Após a avaliação das pressões e ameaças urbanas realizada pelos gestores, foi possível classificá-las de acordo com um grau. Para o cálculo, houve a multiplicação de três itens avaliados (abrangência, impacto e permanência), onde cada pressão e ameaça recebeu um determinado grau, que variou de 1 a 64. Assim, foi possível observar o nível de importância de cada uma para a UC, detalhados no quadro 7.

Quadro 7. Pontuação e grau de severidade das pressões e/ou ameaças, definidos por Ervin (2003). As pressões e/ou ameaças leves receberam uma pontuação entre 01 e 03 . Já as moderadas variaram entre 04 e 09 , as altas receberam um valor entre 10 e 24 , ao passo que as severas ficaram entre 25 e 64 pontos.

\begin{tabular}{|c|c|}
\hline PONTUAÇÃO & GRAU DE SEVERIDADE \\
\hline 1 a 3 & Leve \\
\hline 4 a 9 & Moderado \\
\hline 10 a 24 & Alto \\
\hline 25 a 64 & Severo \\
\hline
\end{tabular}

Fonte: Elaborado pela autora, a partir de Ervin (2003).

A terceira seção teve como objetivo compreender como as equipes de gestão vêm lidando com as pressões e ameaças, isto é, quais ações de convervação vêm sendo implementadas por elas. De maneira geral, o objetivo dessa seção é compreender como eles estão mitigando as atividades potencialmente impactantes para as UCs. 
- Análise de dados

Todas as entrevistas foram registradas em um gravador, mediante autorização dos interlocutores. Posteriormente, foram feitas as transcrições, na íntegra, de todas as entrevistas. Além das entrevistas, materiais extras (e.g. publicações, planos de manejo, folders, cartilhas, entre outros) fornecidos pelas equipes de gestão foram utilizados nas análises, o que contribuiu para a compreensão da realidade das UCs.

A técnica utilizada foi Análise de Conteúdo, a qual apresenta como objetivo aprofundar a análise do conteúdo das informações coletadas, procurando analisar a pertinência das respostas (MICHEL, 2005). Além da descrição dos relatos, essa técnica apresenta como objetivo produzir inferências a partir do conteúdo obtido (BARDIN, 1994).

Como primeira etapa da análise (chamada de pré-análise), todos os dados obtidos foram organizados e sistematizados, provenientes das entrevistas e de materiais extras fornecidos pelas equipes de gestão. Em seguida, foi realizada uma leitura geral desses dados, com objetivo de conhecer as fontes. Na segunda etapa (exploração do material), as informações de conteúdo similar foram agrupadas e separadas por categorias, tais como tipos de pressões, ameaças (e.g. desenvolvimento urbano, caça ilegal, disposição irregular de resíduos) e tipos de ações de conservação implementadas (e.g ações de manejo, ações de uso público, ações de proteção, etc). Essas categorias possibilitam a análise dos dados e a realização de inferências, de acordo com o contexto em que se encontram. Por fim, como terceira e última etapa da análise, consistiu no tratamento dos resultados, na realização de inferências e na interpretação final dos dados obtidos.

\section{Resultados}

Neste item, são apresentados os resultados das análises realizadas de quatro casos de estudos (Parque Estadual do Jaraguá - PEJ, Parque Estadual da Cantareira - PEC, Estação Ecológica de Ribeirão Preto - EERP e Estação Ecológica de Assis - EEcA). Ressalta-se que todos os resultados apresentados neste capítulo são provenientes das opiniões das equipes de gestão, informações coletadas durante as entrevistas, as quais podem carregar um certo grau de subjetividade e incerteza. Logo, os resultados apresentados consistem em uma narrativa dos gestores, figuras importantes e altamente centralizadas no processo de gestão das UCs.

Para cada UC é feita uma breve apresentação, mostrando as suas principais características (contexto, planejamento e insumos), bem como são descritas as suas principais pressões que vêm ocorrendo nos últimos cinco anos e as ameaças que poderão continuar ou trazer novos impactos 
para os próximos cinco anos. De maneira geral, dado o alto número de pressões e ameaças encontradas, procura-se dar maior ênfase na discussão das pressões, visto que estas já estão trazendo impactos prejudiciais às UCs.

Por fim, as ações de conservação que vêm sendo implementadas pelas diferentes equipes de gestão são identificadas e discutidas, buscando-se compreender como elas vêm mitigando seus impactos e quais iniciativas vêm sendo adotadas.

\subsection{Parque Estadual do Jaraguá (PEJ)}

O Parque Estadual do Jaraguá (PEJ) (figura 7) apresenta como objetivos a preservação dos ecossistemas naturais, realização de pesquisas científicas, atividades de educação ambiental, de recreação e turismo ecológico, as quais estão sujeitas às normas e restrições estabelecidas pelo órgão responsável, no caso, a FF. Apesar dos objetivos primordiais serem a conservação dos seus atributos naturais, o Parque apresenta um histórico de mais de 30 anos por ser utilizado como parque de lazer.

Ele foi criado através do Decreto Estadual n 38.391, de 03/05/196 e está inserido na bacia hidrográfica do Rio Tietê (UGRHI 6), cobrindo uma área de 492,68 hectares (ha). Localiza-se na região noroeste da cidade de São Paulo, divisa com o município de Osasco e os bairros de Perus e Pirituba, regiões populosas e alvos da expansão urbana da Região Metropolitana de São Paulo (RMSP). Além disso, insere-se entre três rodovias importantes (Anhanguera, Bandeirantes e o Rodoanel Mario Covas), que conectam o município com o interior paulista.

O PEJ preserva expressivos remanescentes de Mata Atlântica, o qual lhe conferiu o título de Reserva da Biosfera da Mata Atlântica em 1994, pela Organização das Nações Unidas para Educação, Ciência e Cultura (UNESCO), compondo uma das Zonas Núcleos da Reserva da Biosfera do Cinturão Verde da cidade de São Paulo. Desse modo, é um dos poucos refúgios à natureza para a população da região. Ademais, é vizinho de duas comunidades indígenas Guarani, o menor agrupamento indígena do país. 
Figura 7. Imagem de satélite do Parque Estadual do Jaraguá (PEJ), delineado pela cor laranja. A imagem ressalta a sua localização, inserido na malha urbana do município de São Paulo (Estado de São Paulo, Brasil).

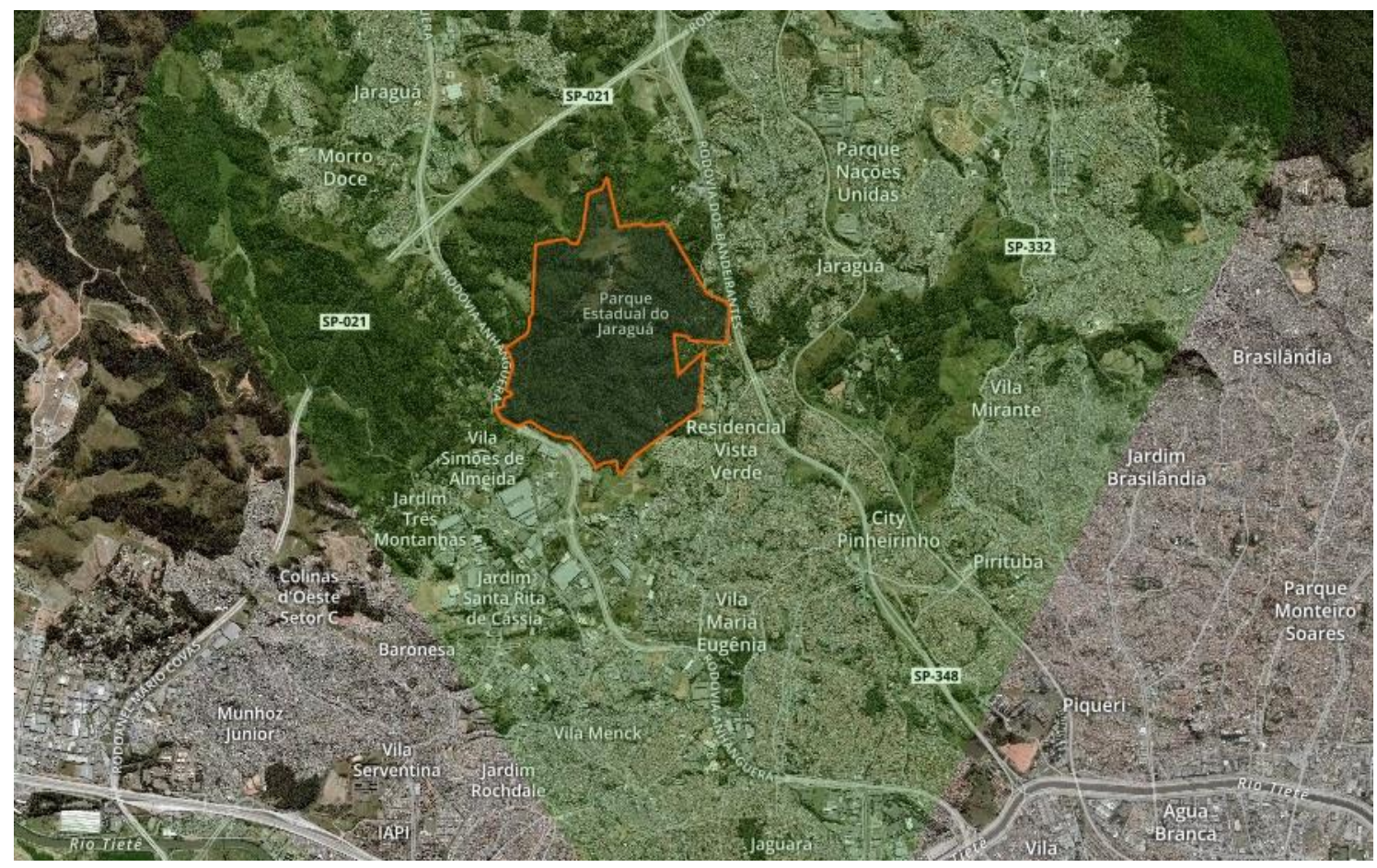

Fonte: IUCN e UNEP-WCMC (2015).

O Parque possui um patrimônio histórico-cultural evidenciado pelo Casarão "Afonso Sardinha" e o "Tanque de lavagem do ouro", estruturas datadas do século XVI e tombadas pelo Conselho de Defesa do Patrimômio Histórico, Artístico, Arqueológico e Turístico do Estado de São Paulo (CONTEPHAAT). Apesar do grande potencial de uso pedagógico e de exploração da história do local proporcionado pelo Casarão, este necessita de restauração e manutenção, visando a sua conservação e a sua operação. Contudo, encontra-se atualmente abandonado e fechado para visitação.

Conforme mencionado anteriormente, o PEJ apresenta um plano de manejo realizado em 2010 e segundo a gestão, o plano é considerado adequado, com metas ligadas aos objetivos específicos de manejo. Durante a sua elaboração, verificou-se a participação da sociedade civil nas oficinas participativas e atualmente observa-se a participação desta através das reuniões dos Conselhos Consultivos, as quais, de acordo com a gestão, ocorrem segundo o atendimento das demandas das câmaras técnicas, não sendo regulares. Também verifica-se a presença de alguns voluntários ligados ao Programa Amigos do Verde da FF, composto majoritariamente por 
estudantes que cumprem horas de estágio, os quais, de maneira geral, participam das atividades de Uso Público.

De maneira geral, as informações da UC são divulgadas através da mídia local (jornal, rádio e TV). As informações mais específicas, de cunho educacional, podem ser encontradas em cartilhas de divulgação, utilizadas nas atividades de educação ambiental dentro do Parque. Além disso, observa-se algumas iniciativas de divulgações sobre os principais atrativos do Parque em websites de cunho turístico. Também existe uma página sobre a UC no website da FF, as quais estão atualizadas, contendo em sua maioria informações usuais ao visitante, mas poucas informações mais específicas (e.g. importância biológica e social da UC). Não foram verificadas informações atualizadas no CNUC, importante canal de divulgação e conhecimento das UCs brasileiras. Ademais, não existe um site interativo, bem como um canal próprio de divulgação das atividades desenvolvidas em mídias sociais.

Em relação aos amparos legais da UC, apesar da situação fundiária estar regularizada, a gestão do PEJ alega que a sua atual demarcação de fronteiras não é adequada para alcançar os objetivos da UC, pois as divisas não são claramente marcadas e compreendidas pela população do entorno. Além disso, a sua localização também foi considerada como não coerente com os seus objetivos de conservação pela gestão, bem como o uso da terra no entorno pode dificultar o alcance dos objetivos de manejo, visto que este se encontra pressionado e ameaçado constantemente pelo seu entorno totalmente urbano, não apresentando possibilidade de conexões com outras áreas naturais.

De acordo com o seu plano de manejo, a zona de amortecimento do PEJ (figura 8) possui 640 ha e foi delimitada em um raio de $2 \mathrm{~km}$ ao seu redor, devido o seu entorno estar densamente ocupado e cercado por rodovias. Para a sua delimitação, foram inclusas a comunidade Indígena Guarani, nascentes, remanescentes florestais importantes do seu entorno, áreas de campos antrópicos, condomínios e chácaras residenciais. Além disso, foram consideradas as legislações do território onde se insere. 
Figura 8. Zona de Amortecimento do Parque Estadual do Jaraguá (PEJ).

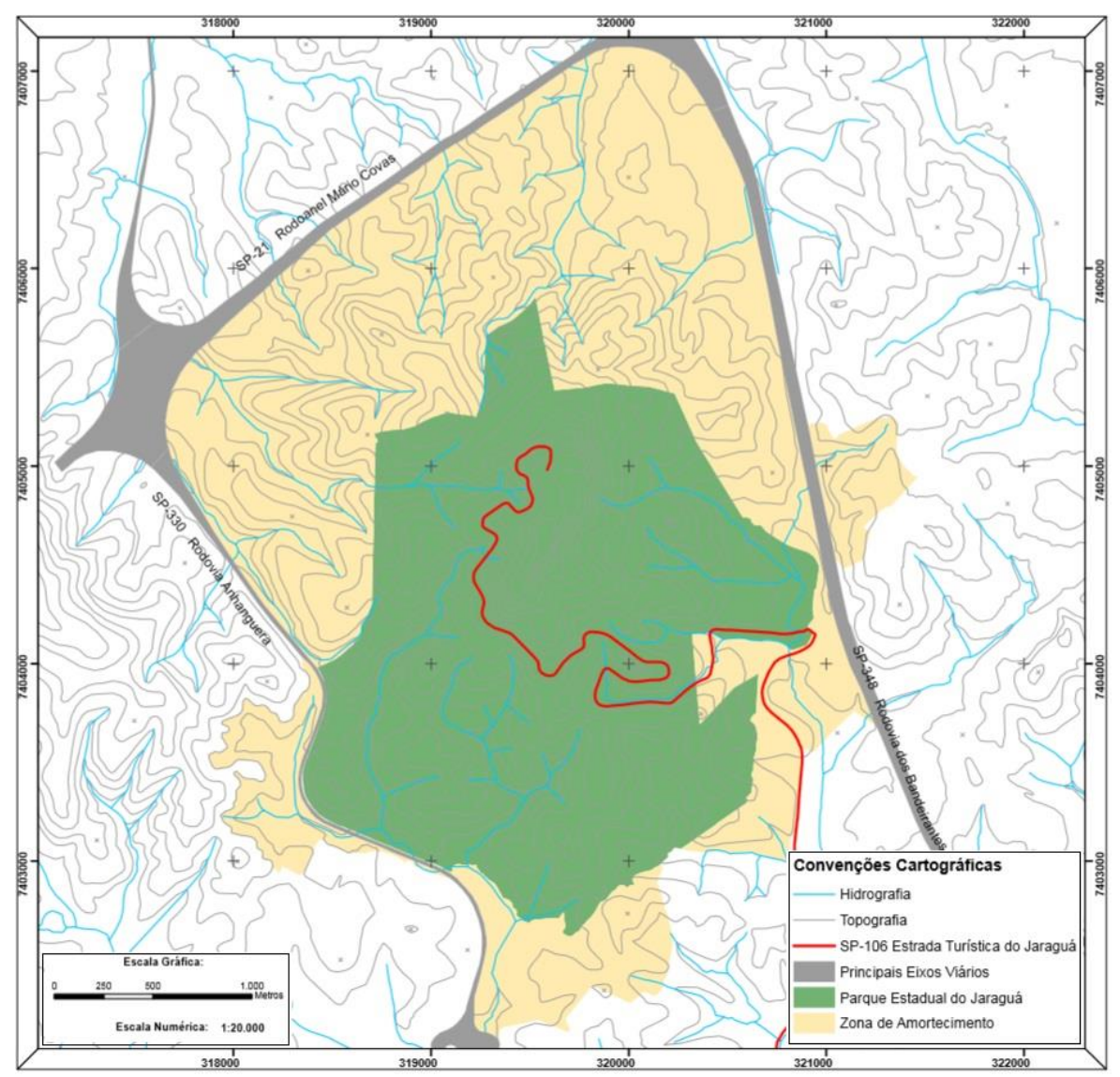

Fonte: Leonel (2010).

Já o zoneamento interno do PEJ (figura 9) foi elaborado levando-se em consideração estudos técnicos sobre os diversos usos no interior e entorno do Parque, realizados durante a criação do Plano de Manejo (LEONEL, 2010). Além disso, as diferentes zonas foram definidas segundo as suas características naturais, culturais, fragilidades e usos, com objetivos de manejo, normas e recomendações específicas, sendo estas: zona primitiva, de recuperação, uso extensivo, uso conflitante, uso intensivo e histórico-cultural (LEONEL, 2010). 
Figura 9. Zoneamento interno do Parque Estadual do Jaraguá (PEJ).

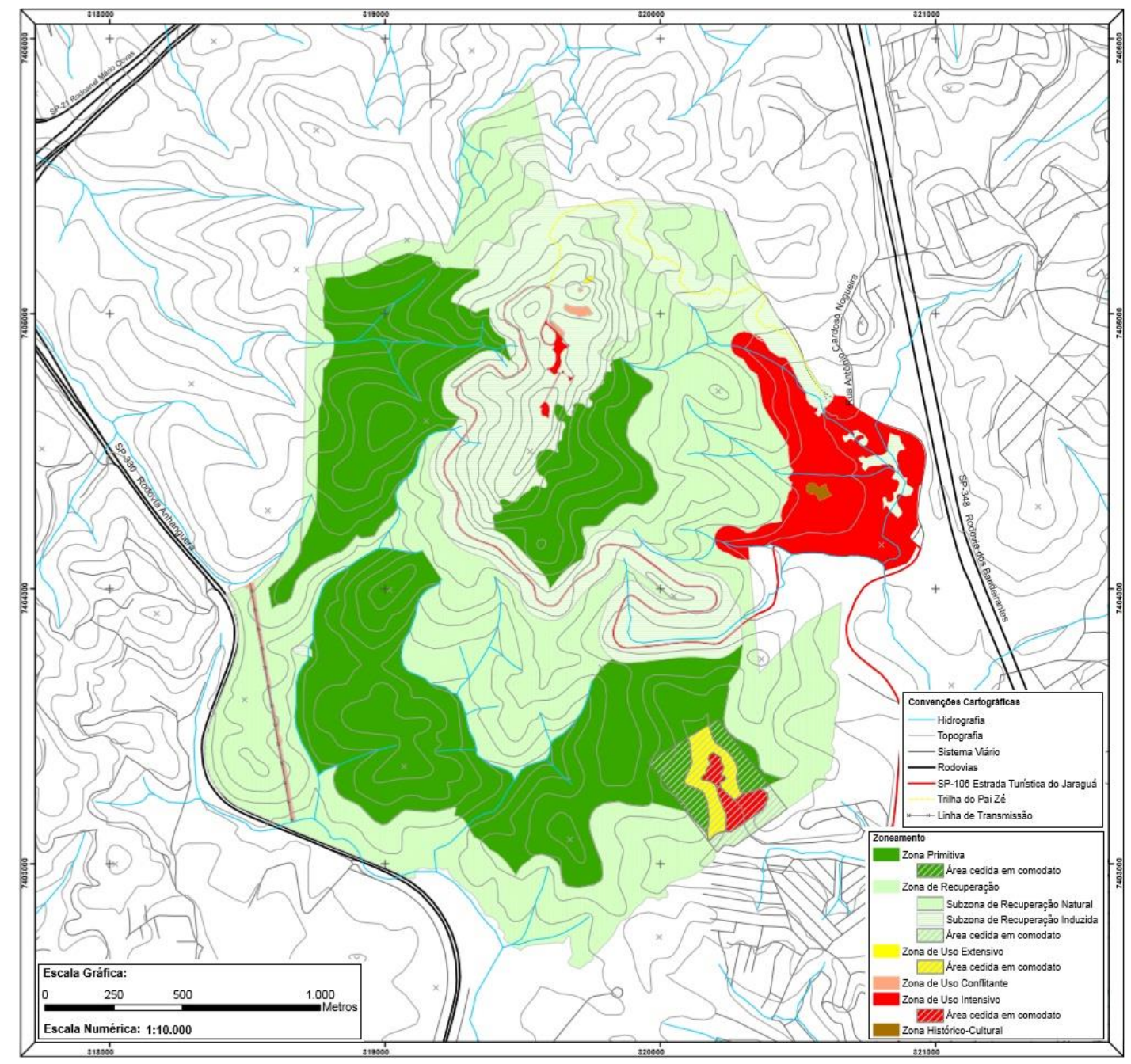

Fonte: Leonel (2010).

No que concerne os recursos humanos do PEJ, embora existam oportunidades de capacitação periódicas para os funcionários e estes possuírem habilidades adequadas para a realização de ações de manejo críticas, a gestão adverte que a quantidade de funcionários não é suficiente para o manejo efetivo da área, bem como existe uma grande rotatividade de funcionários, dificultando a continuidade das ações.

Em relação aos recursos financeiros, verifica-se que os processos para obtenção de recursos para o desenvolvimento dos Programas de Manejo são pouco ágeis e passam por um processo de grande burocracia por parte do órgão gestor. Nesse contexto, a gestão não apresentou uma opinião formada sobre a previsão financeira do Parque. 


\subsubsection{Pressões e Ameaças ${ }^{37}$}

As principais pressões e ameaças do PEJ são identificadas e avaliadas segundo a opinião da gestão da UC, a partir do roteiro dirigido elaborado, baseado no RAPPAM. Elas são discutidas conforme o seu grau de intensidade (figura 10).

Figura 10. Principais pressões e ameaças do Parque Estadual do Jaraguá (PEJ). As pressões e ameaças avaliadas como severas possuem pontuação entre 25 a 64 , as altas possuem pontuação entre 10 a 24 pontos, as moderadas entre 4 a 9 pontos e as leves possuem de 1 a 3 pontos.

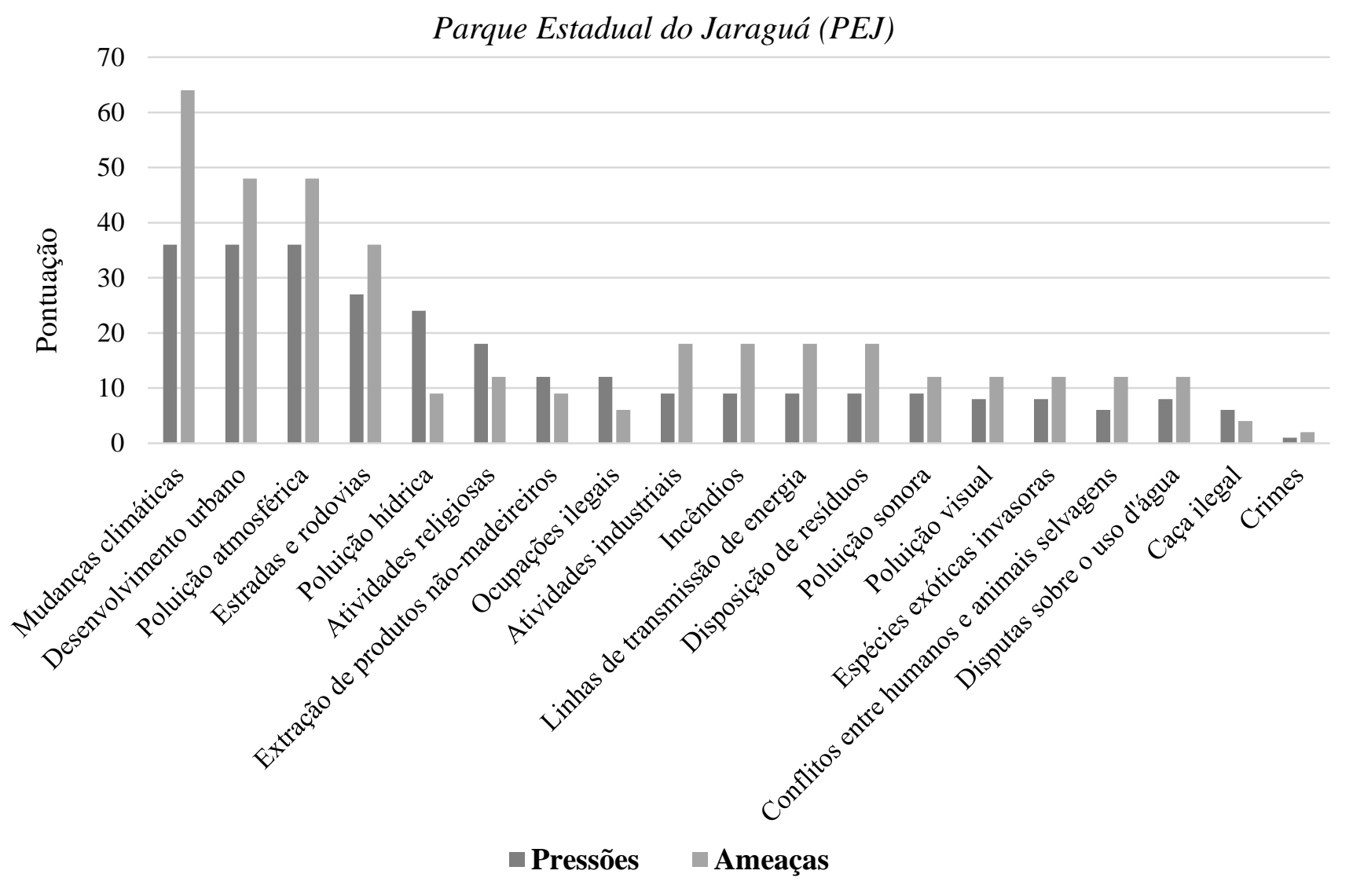

Fonte: Elaborado pela autora (2016), a partir das informações fornecidas pela gestão.

\section{Pressões severas:}

Segundo a gestão, as pressões avaliadas como severas (pontuação de 25 a 64) e que aumentaram ligeiramente nos últimos cinco anos são: mudanças climáticas (36 pontos) e desenvolvimento urbano (36 pontos). Além disso, verificam-se pressões severas que aumentaram

37 Apêndice III. 
ligeiramente nos últimos cinco anos, tais como poluição atmosférica (36 pontos) e a presença de estradas e rodovias (27 pontos).

De acordo com o Art. $2^{\circ}$ da Lei $n^{\circ}$ 12.187, de 29 de dezembro de 2009, que institui a Política Nacional sobre Mudança do Clima (PNMC), as mudanças climáticas são definidas como "mudança de clima que possa ser direta ou indiretamente atribuída à atividade humana que altere a composição da atmosfera mundial e que se some àquela provocada pela variabilidade climática natural observada ao longo de períodos comparáveis". Segundo a gestão do Parque, já é possível notar que diversas nascentes e corpos d'água da UC, que são abastecidos por águas pluviais, vêm sendo seriamente afetados pelos maiores períodos de seca da RMSP. Ademais, a gestão acredita que essa pressão irá aumentar drasticamente de intensidade nos próximos anos (atingindo 64 pontos), trazendo impactos severos ao Parque.

O PEJ encontra-se cercado pelo desenvolvimento urbano do entorno, com áreas urbanizadas consolidadas ao sul, áreas urbano-industriais a oeste, área de expansão urbana a leste, e perirurais a norte e noroeste, com instalações comerciais, residenciais (e.g. chácaras, favelas e condomínios) e rodovias. Além disso, observa-se a grande procura por terrenos formais e informais de baixo custo no entorno do PEJ, bem como ao longo das rodovias Bandeirantes e do Rodoanel.

A poluição atmosférica também é considerada como uma pressão que está trazendo impactos prejudiciais ao Parque, bem como para a população da região. Logo, ela é proveniente do tráfico de veículos que circulam nas estradas e rodovias do entorno, bem como das instalações comerciais e industriais da RMSP. Nesse sentido, a probabilidade dessa pressão aumentar nos próximos anos é avaliada pela gestão como alta, sendo uma ameaça severa (48 pontos). Em contrapartida, o PEJ funciona como um agente de regulação térmica e minimizador da poluição do ar, sendo um dos poucos remanescentes de vegetação da área.

Outra pressão severa é a presença de estradas e rodovias. O PEJ encontra-se cercado pelas rodovias Anhanguera, Bandeirantes e Rodoanel Mario Covas, pela Estrada Túristica do Jaraguá e Avenida Jornalista Paulo Zingg. Em relação aos impactos, verifica-se a ocorrência esporádica de atropelamentos da fauna (e.g. saruê - Didelphis aurita e ouriço cacheiro - Coendou villosus), aumento nos níveis de poluição atmosférica, sonora e visual. Também existe o processo de indução de instalações comerciais e residenciais ao longo das vias, aumentando os impactos devido a presença de assentamentos populacionais no entorno do PEJ. Segundo a gestão, apesar de não estar previsto a criação de novas estradas na região para os próximos cinco anos, é esperado um aumento 
do fluxo de carros, principalmente quando as obras do Rodoanel (área norte) se concretizarem, sendo essa atividade uma ameaça severa à UC (36 pontos).

\section{Pressões altas:}

As pressões avaliadas com alto grau de intensidade (pontuação de 10 a 24) e que permaneceram constante nos últimos cinco anos são: poluição hídrica ( 24 pontos), atividades religiosas (18 pontos) e extração de produtos não-madeireiros (12 pontos). Além disso, verificamse também às ocupações ilegais (12 graus). No entanto, esses eventos aumentaram ligeiramente nos últimos cinco anos.

Em relação à poluição hídrica, ela é originária do lançamento ilegal de efluentes domésticos nos corpos d'água que adentram o Parque, devido a falta de infraestrutura da grande maioria das comunidades do entorno, bem como ocorre devido ao escoamento de resíduos das estradas e rodovias, gerando preocupação devido ao intenso fluxo de veículos e cargas pesadas. Os impactos já observados são acúmulo de resíduos nos corpos d'água, morte de organismos aquáticos, contaminação da água, entre outros. Contudo, a gestão acredita que essa pressão diminuirá de intensidade, devido a previsão de execução de um projeto de engenharia, que de maneira geral, visa conter a emissão desses efluentes, revitalizar os seus corpos d'água e desassorear os sedimentos do lago dentro da UC, sendo uma ameaça moderada à área (9 pontos).

Outra atividade que vem sendo realizada dentro do PEJ são os cultos religiosos. Segundo a gestão, essa atividade ocorre principalmente nos finais de semana e no período noturno, quando a fiscalização é menos intensa. Logo, as invasões ao Parque ocorrem através das rodovias, trazendo impactos para a UC, tais como abertura de clareiras e trilhas ilegais, compactação do solo, perturbação à fauna, aumento do risco de incêndios florestais pelo uso de materiais inflamáveis. Segundo a gestão, devido a intensa fiscalização que está sendo empregada, espera-se que essa pressão diminua de intensidade nos próximos anos (12 pontos).

A extração de produtos não-madeireiros ocorre esporadicamente na UC, por meio de visitantes e moradores do seu entorno, os quais coletam espécies de plantas, na maioria das vezes, com funções medicinais e ornamentais. Nesse sentido, a gestão da UC considera como média a probabilidade dessa pressão continuar a ocorrer nos próximos cinco anos, devido às orientações e abordagens quando são recepcionados na UC, sendo avaliada como uma ameaça moderada pela equipe (9 pontos). 
Outra pressão avaliada como alta são as ocupações ilegais na ZA do Parque. A ausência de ordenamento territorial e valores ambientais no processo de expansão urbana, bem como os altos índices de vulnerabilidade social na RMSP, resultam na presença de assentamentos humanos precários e irregulares no entorno do parque, atividade que aumentou ligeiramente nos últimos cinco anos. As rodovias Bandeirantes e o Rodoanel também são considerados como processos indutores da ocupação urbana, devido a ocorrência de instalações comerciais e habitacionais ao longo de suas vias. Segundo a opinião da gestão, a tendência para os próximos anos é a diminuição de novas ocupações se estabelecerem, devido ao frequente monitoramento e fiscalização nas áreas pertencentes ao PEJ, sendo uma ameaça moderada (6 pontos).

\section{Pressões moderadas:}

As atividades consideradas como pressões moderadas (pontuação de 4 a 9) e que permaneceram constantes nos últimos cinco anos são: atividades industriais ( 9 pontos), incêndios (9 pontos), LTs ( 9 pontos), espécies exóticas invasoras (8 pontos) e disputas sobre o uso d'água (8 pontos). As pressões moderadas que aumentaram ligeiramente nos últimos cinco anos são: poluição sonora (9 pontos), disposição irregular de resíduos ( 9 pontos), poluição visual (8 pontos) e conflitos entre humanos e animais selvagens (6 pontos). Por fim, verifica-se uma pressão moderada que diminui ligeiramente nos últimos cinco anos, a caça ilegal (6 pontos).

Nesse contexto, observa-se uma área industrial consolidada (Zona Exclusivamente Industrial) no entorno imediato do PEJ, localizada ao longo da rodovia Anhanguera, com a ocorrência de galpões industriais e comércio local diversificado, sendo avaliada como uma pressão moderada ao PEJ. Apesar de não haver novas instalações nos últimos cinco anos, a área recebe incentivos fiscais do município de Osasco para à instalação de novas empresas no local ${ }^{38}$, sendo considerada uma ameaça alta ao PEJ (18 pontos).

Em relação aos incêndios, dentre as suas principais causas, destacam-se a limpeza de terrenos nas áreas do entorno e soltura de balões nas periferias, eventos que ocorrem principalmente nas épocas de estiagem. De acordo com a gestão do PEJ, apesar de serem adotadas diversas medidas paliativas de controle aos incêndios e orientações com a população, a probabilidade dessa pressão continuar a ocorrer nos próximos cinco anos ainda é alta, dada a imprevisibilidade desses eventos (atingindo 18 pontos).

\footnotetext{
${ }^{38}$ De acordo com a Lei Complementar Municipal nº123/2004.
} 
Em relação às LTs, existem cinco torres de transmissão de energia elétria no interior do Parque, referente a Companhia de Transmissão de Energia Elétrica Paulista (CTEEP). Apesar do impacto para as espécies de fauna e para a paisagem ser considerado alto, essas linhas apresentam abrangência localizada, e o seu estabelecimento permaneceu constante nos últimos cinco anos, sendo considerada pelo gestor como uma pressão de grau moderado. Como ameaça, visto a crescente tendência no consumo de energia elétrica na RMSP, verifica-se como alta a probabilidade de se estabelecerem mais LTs nos próximos anos na sua ZA.

Outro problema verificado é a presença de espécies exóticas invasoras, dentre as quais merecem destaque a braquiária (Urochloa decumbens) e o capim-gordura (Melinis minutiflora). Elas ocupam grandes áreas do PEJ e áreas de borda, trazendo um impacto prejudicial às espécies nativas. A presença dessas espécies é considerada como uma ameaça alta nos próximos anos, pelo grande potencial de dispersão destes indivíduos, principalmente nas áreas de borda. Além disso, existem muitas espécies frutíferas, tais como a mangueira (Mangifera indica), abacateiro (Persea americana) e limoeiro (Citrus limon), as quais aparentemente não estão trazendo um impaco prejudicial sobre a integridade do parque, pois são poucos indivíduos e estão localizadas em pontos isolados. Contudo, é alta a probabilidade de se dispersarem através da fauna, bem como devido ao desejo da comunidade do entorno em plantar espécies frutíferas e ornamentais (ambas exóticas) nos terrenos do entorno do PEJ (atingindo 12 pontos).

As disputas sobre o uso d'água para consumo da população são avaliadas como pressões moderadas ao PEJ. De acordo com a gestão, existem captações de água no interior da UC para o abastecimento de residências e instalações do entorno, as quais são prejudiciais à manutenção dos corpos d'água e espécies. Além disso, espera-se que essas disputas aumentem nos próximos anos, visto o cenário atual de abastecimento deficitário para a população da região (atingindo 12 pontos).

A poluição sonora e visual ocorrem principalmente devido à proximidade do Parque aos assentamentos humanos e eixos viários. Segundo a gestão da UC, uma das causas da pressão sonora se deve a visitação turística e recreativa, principalmente nos finais de semana, onde observa-se com certa frequência a presença de visitantes utilizando equipamentos de som em volumes altos, na zona de uso público e trilhas. Já a poluição visual é proveniente das luzes noturnas artificiais, e podem interferir significativamente nas espécies e nas funções do ecossistema, acentuando-se conforme a proximidade do PEJ com a área urbanizada do entorno. 
Outra pressão moderada que vem sendo observada é o descarte irregular de lixo (e.g. embalagens de alimentos) e entulhos provenientes da construção civil em algumas regiões localizadas no entorno imediado do PEJ, tais como próximo das aldeias indígenas, estradas e rodovias. Já para o interior do Parque, a produção de resíduos é concentrada nos dias de maior visitação pública, e acondicionado nas lixeiras dispostas por toda área de visitação.

No que concerne os conflitos entre humanos e animais selvagens, estes ocorrem quando os visitantes ou moradores do entorno interagem com os animais para alimentá-los, principalmente com o macaco-prego (Cebus apella). Como resultado, além de prejudicar a saúde animal, esse hábito pode desestimular o animal a buscar o seu próprio alimento, bem como resultar em uma série de riscos (e.g. acidentes e transmissão de doenças), tanto para os animais quanto para os humanos. Também existem alguns casos de atropelamentos registrados pelas rodovias, principalmente com espécies de saruê e ouriço cacheiro. Além disso, verificou-se que não existem campanhas de conscientização sobre doenças infecciosas emergentes, realizadas pela gestão.

Por fim, verifica-se ocorrências de caça ilegal no interior do PEJ. Dentre as espécies de animais silvestres mais procuradas pelos caçadores, destacam-se o tatu, a paca e passeriformes. Segundo a gestão, essa pressão vem diminuindo ligeiramente nos últimos cinco anos, e espera-se que com o aumento das atividades de fiscalização e monitoramento, ela diminua de intensidade nos próximos anos (atingindo 4 pontos).

\section{Pressões leves:}

A única pressão avaliada como leve (pontuação de 1 a 3) pela gestão é a ocorrência de crimes, sendo verificado o uso de drogas e atividades de contrabando próximo ao Parque. De maneira geral, considera-se baixo os impactos resultantes dessa atividade, no que se refere ao sentimento de segurança da população ao visitar o Parque. Contudo, é alta a probabilidade dessas atividades continuarem a ocorrer no seu entorno, por estar inserido na RMSP com altos índices de violência.

De maneira geral, são identificadas 19 tipos de pressões e ameças ao PEJ. Do total, 14 tipos $^{39}$ irão aumentar em algum nível de intensidade nos próximos cinco anos, onde 4 pressões são consideradas como ameaças severas e 10 são ameaças de alto grau de intensidade. Segundo a

\footnotetext{
39 Tais como: mudanças climáticas, desenvolvimento urbano, poluição atmosférica, estradas e rodovias, atividades industriais, incêndios, LTs, disposição irregular de resíduos, poluição sonora, poluição visual, espécies exóticas invasoras, conflitos entre humanos e animais selvagens, disputas sobre o uso d'água e crimes.
} 
gestão, a principal causa desse aumento consiste na intensificação dos processos de urbanização e a velocidade da ocupação do território na região em que o Parque está inserido.

\subsection{Parque Estadual da Cantareira (PEC)}

O Parque Estadual da Cantareira (figura 11) também faz parte do grupo de UCs administradas pela FF. Dada a sua extensão, a gestão da área está dividida em quatro núcleos: Pedra Grande, Águas Claras, Cabuçu e Engordador. Os núcleos possuem autonomia na tomada de decisão, mas devem informar ao chefe do Parque sobre as atividades desenvolvidas, bem como na implantação de estratégias de maior risco.

Ele apresenta território de 7.916,52 ha e localiza-se na região norte do município de São Paulo, abrangendo também as cidades de Mairiporã, Caieiras e Guarulhos. Além disso, foi criado a partir da Lei Estadual nº 6.884, de 29/08/1962, mas regularizado pelo Decreto Estadual n 41.626 , de $30 / 01 / 1963$.

Grande parte do Parque encontra-se inserido na bacia hidrográfica do Rio Tietê (UGRHI 6), compondo a Serra da Cantareira. Além disso, similarmente ao PEJ, também faz parte da Reserva da Biosfera do Cinturão Verde da cidade de São Paulo. Logo, preserva importantes remanescentes de Mata Atlântica na complexa RMSP, possuindo um importante papel no fornecimento de funções ecossistêmicas para a região (e.g. abastecimento de água, amenização das temperaturas, melhoria da qualidade do ar) e contribuindo para o aumento da qualidade de vida da população residente. Nesse sentido, a proteção dos mananciais e da infraestrutura de abastecimento de água para a população paulista fazem parte do patrimônio histórico-cultural do PEC.

Apesar de estar ligado aos Parques Estaduais de Itaberaba e Itapetinga, bem como ser contíguo ao Parque Estadual Alberto Löfgren, o uso do solo do entorno da UC não propicia o manejo efetivo da área, visto que o PEC encontra-se inserido na malha urbana, pressionado e ameaçado pelo desenvolvimento urbano da RMSP. 
Figura 11. Imagem de satélite do Parque Estadual da Cantareira, delineado pela cor laranja. A imagem ressalta a sua localização, inserido na malha urbana do município São Paulo (Estado de São Paulo, Brasil).

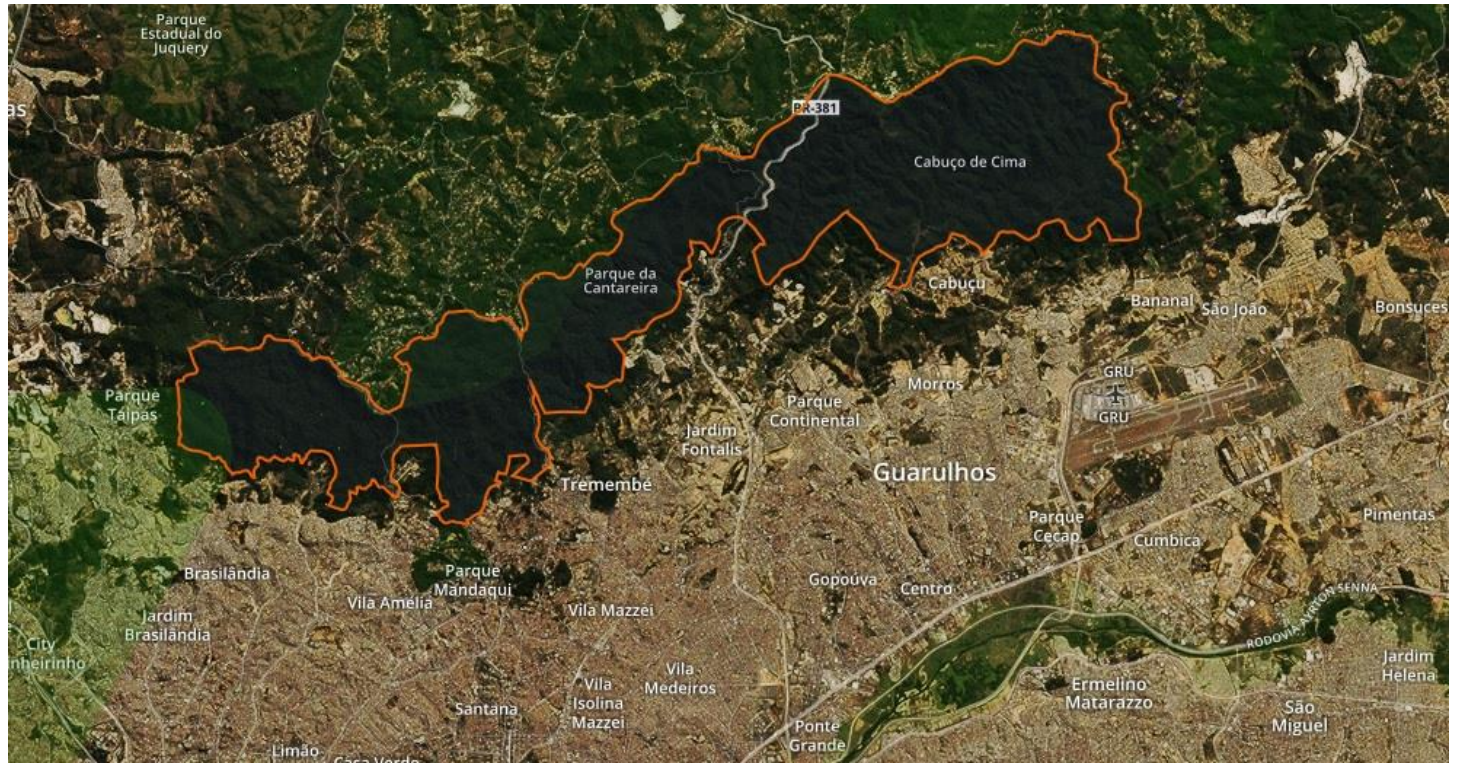

Fonte: IUCN e UNEP-WCMC (2015).

Em relação ao Plano de Manejo do Parque, o qual foi realizado em 2009, não é considerado adequado pela sua gestão, devido a inviabilidade de execução de algumas propostas presente nos seus Programas de Manejo. Como por exemplo, verifica-se que a demarcação de fronteiras atual não é adequada para alcançar os objetivos da UC, onde apenas cerca de 50 a $69 \%$ da UC encontra-se regularizada, bem como existe uma imprecisão dos seus limites (uma distorção no georreferenciamento de aproximadamente 80 metros), problema que favorece a ocorrência de ocupações ilegais e de difícil resolução.

O sistema de zoneamento do PEC foi definido durante a elaboração do seu Plano de Manejo e levou em consideração aspectos ambientais, sociais e culturais, definindo-se zonas de uso intangível, uso primitivo, uso histórico-cultural, recuperação, uso especial, uso extensivo, uso conflitante e uso intensivo (figura 12). 
Figura 12. Zoneamento interno do Parque Estadual da Cantareira (PEC).

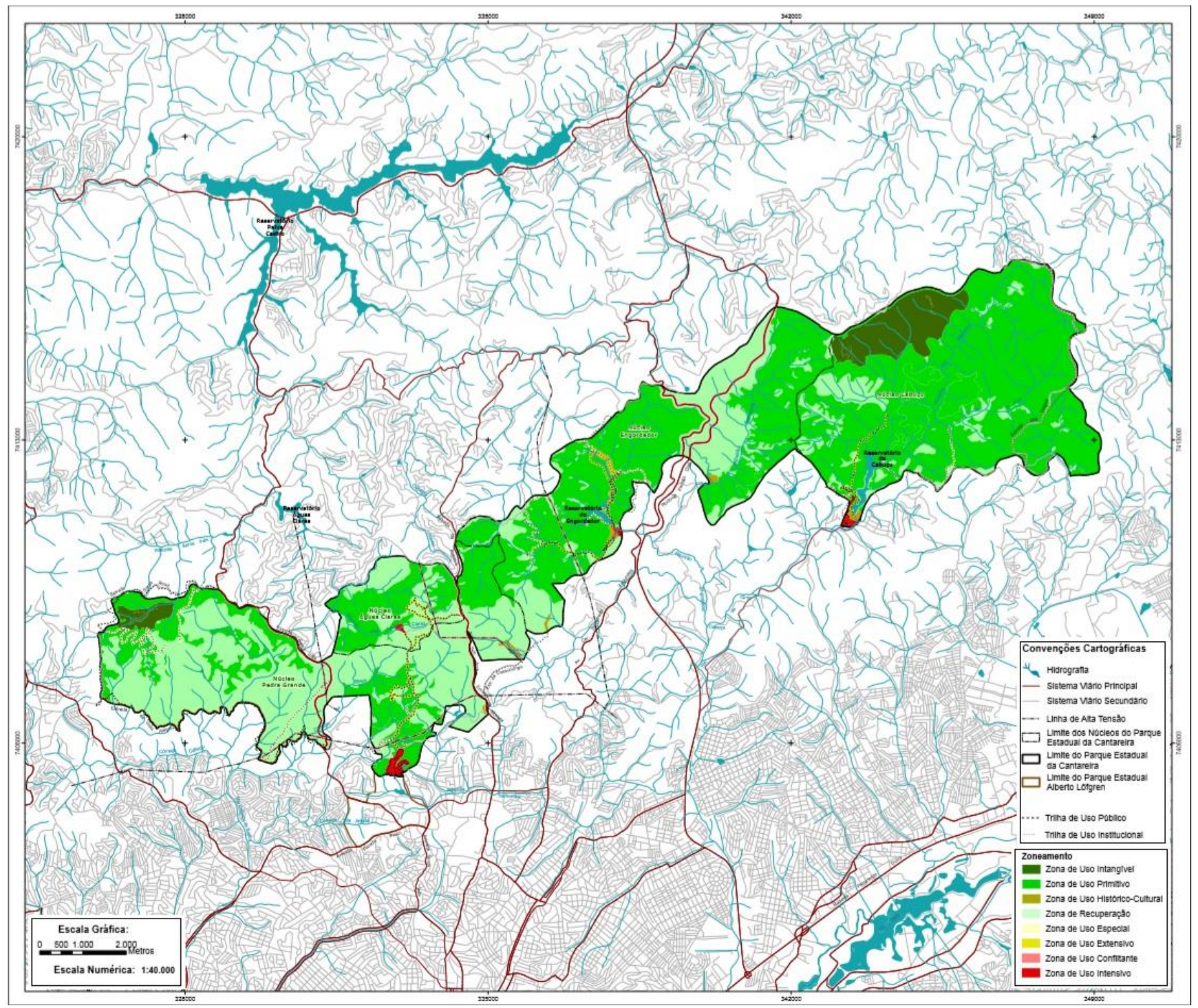

Fonte: Leonel (2009).

De acordo com o plano de manejo do PEC, para a definição da sua zona de amortecimento (ZA), definiu-se como ponto de partida o limite de $10 \mathrm{~km}$ ao redor do Parque, totalizando 35.704 ha. Para tanto, foram consideradas legislações de planejamento territorial e de proteção ambiental de cunho municipal, estadual e federal (figura 13). 
Figura 13. Zona de Amortecimento do Parque Estadual da Cantareira (PEC).

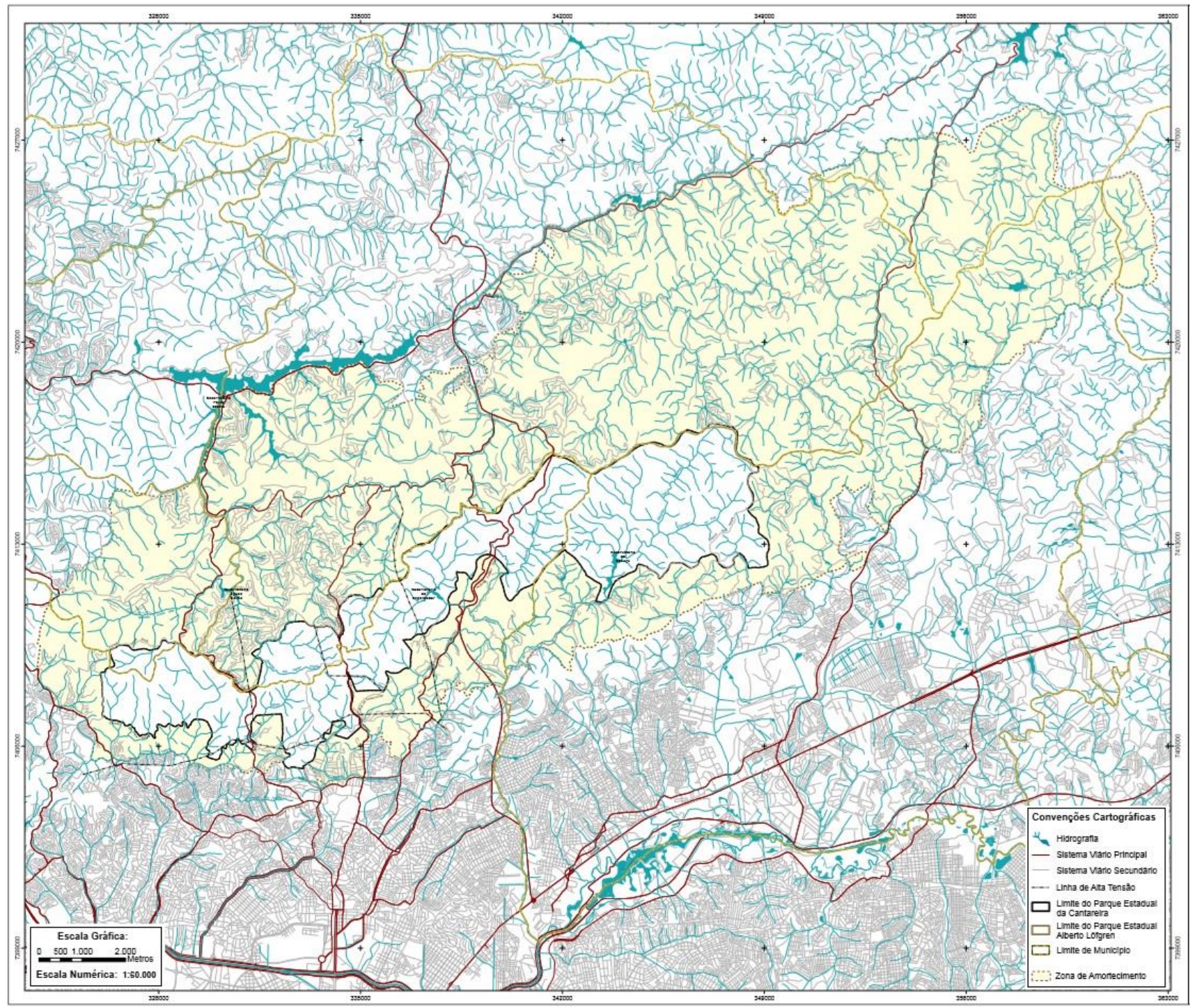

Fonte: Leonel (2009).

Em relação aos mecanismos de participação da sociedade civil na gestão do PEC, verificase a sua atuação nas reuniões do Conselho Consultivo e nas atividades de educação ambiental promovidas pelo Núcleo de Educação Ambiental do Parque. Outra forma de participação ocorre através do Programa de voluntariado, promovido pela FF. No entanto, embora a UC necessite urgentemente de grupos de apoio para a realização de atividades de manejo e de uso público, atualmente não existem voluntários no PEC, pois, segundo a gestão, a procura pela população é muito baixa. Embora a ausência de voluntários, técnicos foram contratados para a realização de ações de manejo na área. De acordo com a gestão, essa iniciativa só foi possível devido ao 
estabelecimento de um convênio com o município de Guarulhos, o qual utiliza uma barragem do PEC para abastecimento urbano.

No que se refere aos meios de divulgação da área, o PEC desenvolveu cartilhas socioeducativas contendo a caracterização e importância como patrimônio natural e para a conservação da biodiversidade utilizada nas atividades de educação ambiental. Além disso, a UC também possui uma página no website da FF, com informações básicas e atualizadas aos visitantes. Apesar de não existir um site interativo com informações mais detalhadas sobre a UC, existe a divulgação de informações importantes relacionadas ao PEC, bem como das atividades educativas, através da mídia local (jornal, rádio e TV) e mídias sociais, a qual também é atualizada frequentemente. Contudo, verifica-se a ausência de informações cadastradas no CNUC, maior banco de dados das UCs brasileiras. Além disso, a gestão adverte que existe um déficit em pessoal capacitado para trabalhar institucionalmente na área de comunicação e marketing da UC, bem como uma falta de um maior fortalecimento da identidade do Parque, com a integração dos quatro núcleos administrativos.

Em relação a infraestrutura do Parque, a gestão alega que as estruturas disponíveis (e.g. fornecimento de água, segurança, banheiros) não estão de acordo com as demandas de uso público da área, necessitando de melhoras com urgência. Além disso, adverte que os recursos financeiros dos últimos cinco anos não foram adequados para realizar ações de manejo críticas, bem como não há previsão financeira estável para a UC a longo prazo. Desse modo, observa-se que os recursos financeiros do PEC são advindos do Governo do Estado de São Paulo, licenciamentos ambientais e também gera-se receita através da cobrança de ingressos e pela comercialização dos passaportes para o Projeto "Trilhas de São Paulo". Ademais, de maneira similar ao PEJ, também verifica-se frequentes burocracias nas solicitações de recursos financeiros pelo órgão gestor. 


\subsubsection{Pressões e Ameaças ${ }^{40}$}

De maneira geral, são identificados 20 tipos de pressões e ameaças no PEC, as quais foram avaliadas pela gestão conforme a sua ocorrência, abrangência, impacto e permanência (figura 14), durante a realização da entrevista.

Figura 14. Principais pressões e ameaças do Parque Estadual da Cantareira. As pressões e ameaças avaliadas como severas possuem pontuação entre 25 a 64, as altas possuem pontuação entre 10 a 24 pontos, as moderadas entre 4 a 9 pontos e as leves possuem de 1 a 3 pontos.

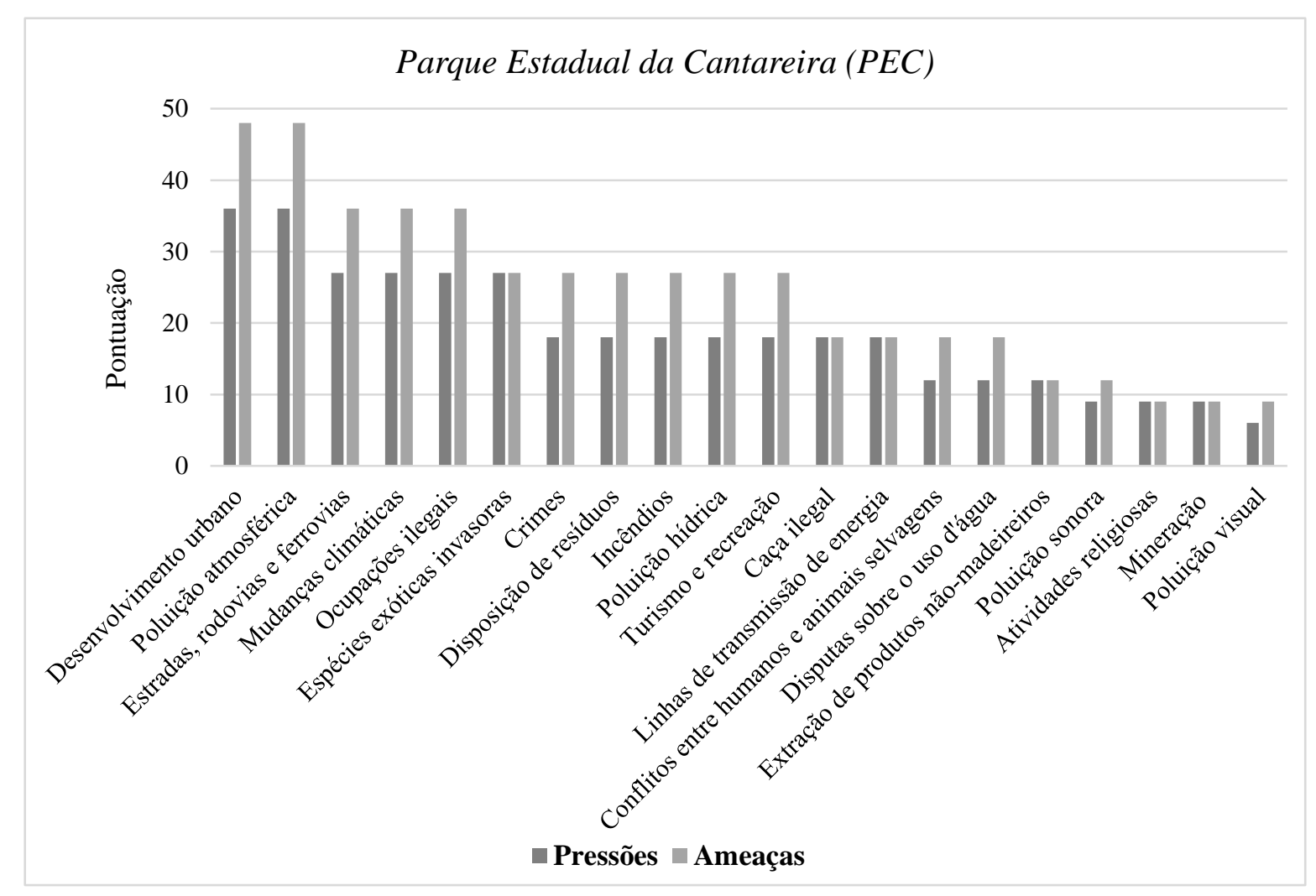

Fonte: Elaborado pela autora (2016), a partir das informações fornecidas pela gestão.

Pressões severas:

As principais pressões avaliadas como severas (pontuação de 25 a 64) e que aumentaram drasticamente nos últimos cinco anos são: desenvolvimento urbano (36 pontos), poluição atmosférica (36 pontos), ocupações ilegais (27 pontos) e espécies exóticas invasoras (27 pontos). Além disso, verificam-se pressões severas que aumentaram ligeiramente nos últimos cinco anos, tais como a presença de estradas e rodovias (27 pontos) e as mudanças climáticas (27 pontos).

\footnotetext{
40 Apêndice IV.
} 
Nesse sentido, a RMSP é uma das dez regiões metropolitanas mais populosas do Brasil, sendo o principal polo econômico do país. É nesse contexto que o PEC está inserido, possuindo em seu entorno uma densa ocupação humana, com assentamentos precários e irregulares (e.g. favelas e loteamentos), condomínios de alto padrão, chácaras residenciais, vias de acesso (estradas e rodovias), indústrias e atividades de mineração. Segundo a gestão do Parque, o aumento drástico é evidenciado pelas altas taxas de crescimento populacional dos municípios abrangidos (Caieiras, Mairiporã e Guarulhos), superiores às da média da região, resultando em maiores demandas por infraestrutura (e.g. moradia, saúde, lazer, educação). Essa alta demanda, associado ao perfil de baixa e média renda da população do entorno, resultam em pressões e ameaças severas à integridade do PEC. Além disso, mesmo existindo instrumentos que regulam o uso e ocupação do solo no seu entorno (Planos Diretores e a Lei de Uso e Ocupação do Solo dos municípios abrangidos), a gestão adverte que estes não são suficientes para controlar a rápida expansão urbana da região, visto o aumento das ocupações irregulares nos últimos anos.

A poluição atmosférica é proveniente principalmente da queima de combustíveis fósseis de veículos motorizados, instalações comerciais, industriais e atividades de mineração no entorno do Parque. Apesar da UC ser privilegiada por estar em altitudes mais elevada (acima de $850 \mathrm{~m}$ ), os efeitos da poluição atmosférica são visíveis. A poluição atmosférica é também responsável pelo aumento das temperaturas durante o dia, das concentrações de gases poluentes no ambiente, chuvas ácidas, efeito estufa, inversão térmica, por alterações nos ciclos hidrológicos, comprometimento da saúde dos organismos em geral, entre outros.

O PEC é cortado por vias de acesso, tais como a Estrada da Roseira, Estrada Santa Inês, e Rodovia BR-381 Fernão Dias. Também existem algumas estradas de terras e caminhos de terratrilha, margeando e cortando o PEC, bem como um trecho de $8 \mathrm{~km}$ do Rodoanel Mário Covas, beirando a face sul da UC. A presença dessas vias aumenta a vulnerabilidade do Parque, resultando em diversos impactos, tais como barreiras a passagens da fauna (dificultando o fluxo gênico), atropelamentos, fragmentação florestal, perda da biodiversidade, poluição atmosférica, sonora, visual, disposição irregular de resíduos (e.g. lixo, entulho), acidentes por produtos tóxicos de transportes de carga pesada, incêndios, invasões e ocupações urbanas no entorno, entre outras. Já os acessos terra-trilha facilitam o uso indevido da área para atividades religiosas, caça, extração de recursos, crimes, entre outras pressões. Além disso, espera-se um aumento considerável do fluxo 
de veículos, bem como um futuro licenciamento de uma ferrovia para transporte de carga, a qual irá margear uma grande parcela do PEC, com cerca de $53 \mathrm{~km}$ de extensão.

Similarmente ao PEJ, a gestão do PEC já vem observando graves diminuições na vazão de determinados cursos d'água da UC, impacto atribuído às mudanças climáticas durante os últimos cinco anos. Desse modo, é esperado que esses impactos se agravem nos próximos anos, visto a intensificação do desenvolvimento urbano da RMSP (atingindo 36 pontos).

Outra pressão que vêm aumentando drasticamente nos últimos cinco anos são as ocupações ilegais nas áreas limítrofes ao Parque. Segundo a gestão da UC, existem tanto assentamentos precários (e.g. loteamentos e favelas), facilitados pela aquisição de terrenos a baixo custo, quanto condomínios de alto padrão (e.g. Condomínio Golf Club). Atualmente também existe um processo de revisão do zoneamento do município de São Paulo, onde existem intenções de alteração de áreas que compõem a ZA do PEC (atualmente Zona Especial de Proteção Ambiental - ZEPAM) para Zona Mista - ZM (com restrição mais flexível, permitindo usos residenciais e não residenciais). Segundo a gestão, essa mudança resultará em novos assentamentos habitacionais e na expansão dos assentamentos existentes, sendo uma ameaça severa ao PEC (36 pontos). Os impactos ocasionados por essas ocupações são diversos, tais como: lançamento inadequado de esgotos domésticos, disposição irregular de resíduos, supressão de vegetação, impermeabilização do solo, assoreamento e poluição dos corpos d'água, proliferação de vetores de zoonoses, entre outros.

As espécies exóticas invasoras vêm aumentado drasticamente nos últimos cinco anos, principalmente nas áreas de borda do PEC, onde a ocupação urbana é mais intensa. Segundo o gestor, verifica-se com certa frequência a população do entorno plantando espécies exóticas frutíferas, ornamentais e medicinais, as quais se propagam com grande facilidade. Destacam-se algumas espécies introduzidas com fins ornamentais, tais como maria-sem-vergonha (Impatiens walleriana), palmeira-leque (Livistona chinensis) e lírio-do-brejo (Hedychium coronarium); plantas forrageiras, tais como capim-gordura (Melinis minutiflora), braquiária (Brachiaria brizantha), entre outras. Das espécies de fauna exóticas invasoras destacam-se os cães domésticos (Canis familiaris) e gatos (Felis catus). Essas espécies adentram o Parque conforme o avanço da ocupação humana no entorno, sendo grandes predadores da fauna nativa e podendo transmitir doenças. Desse modo, a gestão alega que é alta a probabilidade dessa pressão continuar a ocorrer 
no PEC, sendo um problema permanente, visto a imprevisibilidade das ações dos moradores do entorno e demais processos introdutórios dessas espécies.

\section{Pressões altas:}

As pressões avaliadas como altas (pontuação de 10 a 24) e que aumentaram drasticamente nos últimos cinco anos são: crimes (18 pontos), disposição de resíduos (18 pontos), ocorrência de incêndios florestais (18 pontos), atividades de turismo e recreação (18 pontos) e disputas sobre o uso d'água (12 pontos). Já as pressões altas que aumentaram ligeiramente nos últimos cinco anos são os conflitos entre humanos e animais selvagens (12 pontos). Por fim, aquelas que permaneceram constantes são: poluição hídrica (18 pontos), caça ilegal (18 pontos), estabelecimento de LTs (18 pontos) e extração de produtos não-madeireiros (12 pontos).

Verificam-se a ocorrência de crimes no interior do PEC e no seu entorno imediato nos últimos cinco anos, tais como abandono de veículos motorizados, uso de substâncias ilícitas de visitantes, roubo de cargas na Rodovia Fernão Dias que corta o PEC, sequestro de motoristas, assaltos no interior de um dos Núcleos, bem como o Parque vem sendo uma das rotas de fuga de assaltantes de condomínios da região. Segundo a gestão, a probabilidade dessa ameaça continuar a ocorrer é alta, visto o aumento da violência na RMSP (atingindo 27 pontos).

Mais uma pressão avaliada como alta é a disposição irregular de resíduos. De maneira geral, ela ocorre dada a proximidade do PEC com assentamentos urbanos (e.g. loteamentos, favelas) e também por ser cortado por diferentes vias de acesso. Desse modo, a zona de entorno do Parque recebe resíduos de origem variada, tais como resíduos domésticos, industriais, químicos, farmacêuticos, da construção civil (e.g. tintas, solventes, entulhos), esgoto não tratado, desmanche de veículos, entre outros. Além disso, verifica-se também a disposição irregular de lixo proveniente da visitação pública no interior da UC (e.g. embalagens de alimentos, garrafas plásticas), na qual não há coleta seletiva. Alguns dos impactos observados são contaminação da fauna, poluição dos recursos hídricos e solos, transmissão de doenças e comprometimento do aspecto cênico da área.

Segundo o gestor, a questão do lixo é um problema de difícil solução. Existe uma grande dificuldade em conter essas práticas no entorno pois na maioria das vezes elas ocorrem no período noturno, onde a fiscalização do PEC é limitada. Também existe o problema de averiguar a origem desses resíduos, pois frequentemente os resíduos descartados não apresentam recipientes ou indícios de sua origem. Em relação às vias de acesso que cortam o PEC, existe a imprevisibilidade das ações dos motoristas e pedestres que circulam nas vias. Além disso, o PEC é aberto para 
visitação pública aos finais de semana, onde as atividades são encerradas às 17 horas. Logo, os visitantes produzem lixo até essa hora, não havendo funcionários para a realização da limpeza após esse período. A limpeza é feita apenas no dia seguinte, e como resultado, os resíduos nas lixeiras ficam expostos para a fauna (e.g. quatis, gambás, macaco-prego), a qual se alimenta deles. Assim, verifica-se a necessidade de melhorias para o dimensionamento das demandas da gestão operacional do PEC, visto a alta probabilidade dessa pressão continuar a ocorrer nos próximos cinco anos, uma ameaça considerada severa para a área (27 pontos).

Também se verificam ocorrências de incêndios florestais no Parque, considerados como altas pressões. De acordo com o gestor, essa pressão vem aumentando drasticamente, principalmente por causa dos períodos de seca atípicos. Na maioria das vezes os incêndios são originados nas áreas de borda do PEC onde existe o contato da floresta com gramíneas (e.g. capimgordura - Melinis minutiflora - e braquiária - Brachiaria brizantha), ou seja, nas áreas de entorno dos seus limites e nas margens de estradas e rodovias que o cortam, onde as ocupações ilegais ocorrem. Logo, verifica-se que grande parte dos incêndios são resultados de limpezas de terrenos desses moradores, bem como da soltura de balões nas áreas periféricas ao PEC. Os impactos são diversos, tais como: poluição atmosférica, comprometimento da saúde dos organismos, emissão de gases de efeito estufa, devastação florestal, danos aos ecossistemas, entre outros.

Outra pressão alta é o turismo e recreação. Ressalta-se que o Parque apresenta um alto potencial recreativo e turístico, possuindo diversos atrativos, tais como o mirante da Pedra Grande, trilhas (e.g. Figueira, Bica, Pedra Grande), cachoeiras (Cabuçu), represas (e.g. Engordador e Cabuçu), lago (e.g. Lago das Carpas) e amostras do patrimônio histórico/cultural (e.g. barragens do Engordador e do Cabuçu, Casa das Bombas, Casa da Caldeira). De maneira geral, são permitidas atividades de uso público de baixo impacto ao meio físico e biótico (e.g. observação de fauna, interpretação e contemplação da paisagem e caminhadas nas trilhas sem o uso de instrumentos sonoros), com objetivos de educação, lazer e recreação. Além dos atrativos, os núcleos contam com mínima infraestrutura de uso público, tais como portarias, bilheterias, sanitários, centro de visitantes, audiovisual, anfiteatros e museus.

No entanto, existem algumas questões que limitam o seu potencial. Apesar de haver mínima infraestrutura e serviços terceirizados prestados no PEC (e.g. vigilância patrimonial, serviços de portaria e monitoria ambiental), o gestor alega que não são oferecidos alguns serviços básicos aos visitantes, tais como lanchonetes, quiosques e bebedouros, bem como as áreas de 
piqueniques são escassas. Assim, verifica-se que muitas vezes os visitantes não compreendem a cobrança de ingressos e acabam não retornando ao Parque. Além disso, a demanda por usos da unidade muitas vezes não condiz com os objetivos do PEC, onde grande parte do público não compreende que o local é uma UC de Proteção Integral, confundindo-a com um parque urbano, de uso mais flexível. Esse conflito é agravado devido a proximidade com o Parque Estadual Alberto Löfgren (ou Horto Florestal), o qual apesar de também ser uma UC da mesma categoria, possui quadra poliesportiva, campo de futebol e parque infantil. Assim, é frequente a presença de ciclistas em áreas irregulares, indivíduos com aparelhos de som e uso de substâncias ilícitas, entre outros.

O processo de expansão urbana da RMSP resultou no quase completo esgotamento dos recursos naturais, região em que o PEC está localizado. Logo, a região concentra a maior população do país, a qual demanda por espaços de recreação e turismo que proporcionem maiores oportunidades de contato com as áreas naturais e aumentem a qualidade de vida. Nesse sentido, as recentes crises econômicas do país, associadas ao baixo poder aquisitivo de grande parcela da população da Cantareira aumentaram drasticamente a procura por atividades de lazer de baixo custo no Parque nos últimos cinco anos, sendo uma ameaça severa ao Parque (27 pontos). Como evidência, entre 2003 e 2008, o PEC recebia uma média de 60 mil visitantes por ano, ao passo que em 2015 o número de ingressos vendidos foi de 130 mil. Assim, a gestão do PEC possui um enorme desafio em conciliar o desenvolvimento urbano do entorno com a conservação dos recursos naturais, bem como em oferecer atividades de recreação e turismo de baixo impacto para a UC.

Outro limitante observado é o baixo aproveitamento do potencial turístico e recreativo do PEC pelas agências de turismo locais. Segundo o plano de manejo do Parque, isso se deve pelo fato do Parque abrir para visitação apenas nos finais de semana e feriados, ao passo que nos dias de semana os núcleos recebem visitas de determinados grupos agendados (e.g. escolas, idosos, pessoas com necessidades especiais), dificultando para as agências oferecerem o PEC como roteiro turístico. Os impactos oriundos do turismo e recreação observados são diversos, tais como: compactação dos solos e supressão da vegetação resultante do pisoteamento fora das trilhas oficiais, aumento do lixo, violência (e.g. assaltos) nos locais com maior número de turistas, entre outros. Além disso, o gestor alega que o PEC não possui um número de funcionários suficientes para a demanda atual de visitantes.

Mais uma pressão avaliada como alta é as disputas sobre o uso d'água no PEC. De acordo com o gestor, existem dois fatores que têm contribuído severamente para o aumento dessa pressão, 
o aumento dos períodos de seca nos últimos anos, bem como a consolidação das ocupações irregulares na RMSP. Logo, a rápida expansão urbana resulta em uma série de captações de água irregulares, visto a precária distribuição de água da rede pública. Como consequência, essas atividades podem resultar na degradação dos recursos hídricos do PEC, bem como gerar conflitos entre esses moradores e a gestão do Parque, sendo esperado para os próximos anos um aumento no nível de intensidade dessa pressão (18 pontos).

Os conflitos entre humanos e animais selvagens ocorrem devido a consolidação das ocupações urbanas no entorno imediato do Parque, sejam elas regulares ou irregulares, e estes vêm aumentando ligeiramente durante os últimos cinco anos. De acordo com o gestor, os principais conflitos observados são a entrada de fauna (e.g. esquilos - Guerlinguetus ingrami, bugios Alouatta clamitans, quatis - Nasua nasua) nas residências mais próximas e o oferecimento de alimentos para esses animais silvestres por parte dos visitantes do Parque. Como consequência, esses animais acabam se habitando à presença humana, aumentando-se os riscos de transmissão de zoonoses, acidentes, além de causar um desequilíbrio nas dietas alimentares e comprometimento da saúde destes.

A poluição dos recursos hídricos também configura-se como um dos vetores de alta pressão na região do entorno do Parque. Conforme mencionado, o modelo de urbanização da região resultou no estabelecimento de ocupações ilegais e vias de fácil acesso ao PEC, trazendo resíduos (e.g. esgoto sanitário, produtos químicos) que podem conter substâncias que auxiliam no processo de contaminação dos corpos d'água da sua ZA. Felizmente, grande parte desses corpos d'água saem do Parque, concentrando o problema da poluição nas regiões do entorno.

Outra atividade considerada como uma alta pressão é a caça ilegal da fauna. Segundo o gestor, apesar da frequência ser baixa em relação a demais regiões de Mata Atlântica, ainda verifica-se a caça de algumas espécies de pequeno porte (e.g. pássaros), e alguns casos esporádicos de animais de grande porte (e.g. paca - Cuniculus paca), por caçadores de maior idade, ainda simpatizantes com a cultura da caça. Nesse sentido, não há nenhuma espécie alvo de significativo valor econômico, sendo esta atividade realizada para fins de criação própria. Como resultado dessa prática, observam-se impactos para as populações alvos da caça, bem como compactação do solo, supressão da vegetação e abertura de trilhas ilegais.

Existem LTs que cortam o território do PEC e representam uma alta pressão e ameaça a UC, pertencentes as empresas da CTEEP, Eletropaulo Metropolitana Eletricidade de São Paulo e 
Furnas. Os impactos observados são supressão de vegetação, incêndios, alteração da paisagem e abertura de vias de acesso indutoras de atividades ilegais (e.g. caça, pesca, extração de recursos).

Verifica-se ocorrências de extração de produtos não madeireiros nas áreas de uso público e áreas limítrofes ao PEC, tais como plantas medicinais e ornamentais (e.g. orquídeas e bromélias). Essa atividade ocorre por parte de visitantes e moradores do entorno.

\section{Pressões moderadas:}

As pressões consideradas moderadas (pontuação de 4 a 9) e que aumentaram ligeiramente nos últimos cinco anos são: poluição sonora ( 9 pontos), atividades religiosas ( 9 pontos) e poluição visual (6 pontos). Além disso, atividades de mineração (9 pontos) também são avaliadas como pressões moderadas, mas que permaneceram constantes nos últimos cinco anos.

A poluição sonora é considerada um problema ambiental nos centros urbanos e é proveniente da emissão de sons que excedem os níveis considerados aceitáveis para os organismos, gerando impactos severos para o PEC (e.g. afugentamento, desorientação e diminuição de populações faunísticas). Ela ocorre devido a intensa ocupação urbana nas áreas limítrofes ao PEC, tais como a proximidade das vias de acesso (e.g. fluxo de veículos motorizados), a presença de assentamentos humanos (e.g. casas noturnas, bares, eventos, eletrodomésticos), bem como do fluxo de aeronaves do Aeroporto Internacional de São Paulo. Além disso, a intensa visitação turística nos finais de semana também são fontes de poluição sonora.

Outra pressão moderada são as práticas religiosas no PEC. Essas atividades ocorrem geralmente nos finais de semana e períodos noturnos, onde a fiscalização é mais limitada. Desse modo, resultam muitas vezes na supressão da vegetação (abertura de clareiras e trilhas) e descarte de resíduos, potencializando o risco de incêndios através do uso de velas.

As atividades de mineração no entorno do PEC vêm sendo realizadas por duas pedreiras (Pedreira Basalto 14 e Pedreira Santana) localizadas próximas ao Núcleo Engordador. Nos últimos cinco anos, não houve o estabelecimento de novas atividades de mineração no entorno do PEC. Contudo, existem impactos diretos sobre a biota e meio físico, tais como afugentamento da fauna, supressão da cobertura vegetal original, poluição do ar, água, solo e sonora, alteração no regime hídrico, perda de biodiversidade, entre outros. Além disso, verifica-se o descarte irregular de sedimentos dentro da UC, os quais são depositados em um dos córregos do PEC, agravando a situação durante a ocorrência de chuvas. 
A poluição visual é resultante do aumento da luminosidade artificial noturna nos ambientes urbanos (iluminação pública das vias de acesso, luzes de veículos motorizados e residências). As radiações emitidas podem ser prejudiciais para a saúde dos diversos organismos, trazendo impactos nos ciclos migratórios, alimentares e reprodutivos de diversas espécies.

Por fim, verificam-se que dos 20 tipos de pressões e ameaças identificadas, 14 tipos $^{41}$ irão aumentar em algum grau de intensidade nos próximos cinco anos. Do total, 10 serão ameaças severas. De maneira geral, a gestão acredita que a consolidação dos processos urbanos na região onde o PEC encontra-se inserido e as diversas atividades de interesse público relacionadas, bem como o aumento do número e fluxo de pessoas na RMSP são as principais causas que levarão ao aumento do nível de intensidade das pressões atualmente existentes.

\subsection{Estação Ecológica de Ribeirão Preto (EERP)}

A Estação Ecológica de Ribeirão Preto (EERP), também conhecida como Mata de Santa Tereza, pertence ao grupo de UCs de Proteção Integral do Estado de São Paulo, cuja categoria tem como objetivo a preservação da natureza e a realização de pesquisas científicas. A visitação pública é proibida ${ }^{42}$, com exceção para os casos com objetivos educacionais, de acordo com o seu Plano de Manejo. Além disso, a realização de pesquisas científicas depende de autorização prévia do órgão gestor, que no caso da EERP, é de responsabilidade da FF.

Em 1984, com o Decreto $n^{\circ} 22.691$, de 13/09/1984, o fragmento de 154,16 ha, que anteriormente era uma antiga fazenda de café, foi transformado em ESEC e incorporado ao acervo do Serviço Florestal do Estado. A UC está completamente inserida na sua zona de expansão urbana, região intensamente atropizada (figura 15) e os usos atuais do seu entorno são caracterizados pela expansão urbana (área urbana, condomínios residenciais, loteamentos, Rodovia SP-332) e agrícola (e.g. cana-de-açúcar, cultura temporária, pastagem), o que implica em reduzida ocorrência de remanescentes de vegetação e fauna silvestre.

\footnotetext{
41 Tais como: desenvolvimento urbano, poluição atmosférica, estradas, rodovias e ferrovias, mudanças climáticas, ocupações ilegais, crimes, disposição de resíduos, incêndios, poluição hídrica, turismo e recreação, conflitos entre humanos e animais selvagens, disputas sobre o uso d'água, poluição sonora e visual.

${ }^{42}$ Segundo o Plano de Manejo e gestão da UC, apesar da visitação pública ser proibida, existe uma demanda reprimida de visitação para a EERP, devido a proximidade da área ao núcleo urbano de Ribeirão Preto.
} 
Figura 15. Imagem de satélite da Estação Ecológica de Ribeirão Preto (EERP), delineada pela cor laranja. A imagem ressalta a sua localização, inserida na zona de expansão urbana do município de Ribeirão Preto (Estado São Paulo, Brasil).

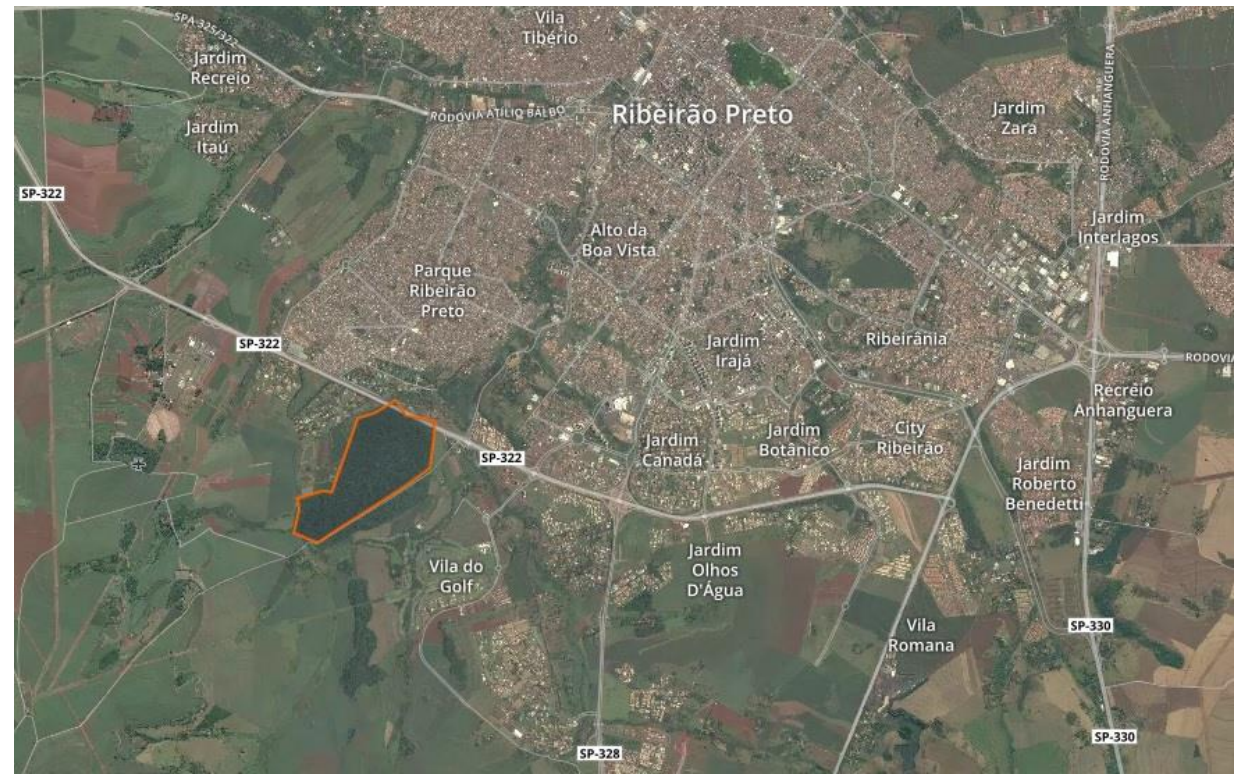

Fonte: IUCN e UNEP-WCMC (2015).

Nesse contexto, a EERP representa um dos maiores fragmentos de floresta estacional semidecidual de uma região extremamente degradada e encontra-se isolada de remanescentes florestais maiores, tornando-a extremamente relevante para sua região (VARANDAS et al., 2015). Assim, a UC e sua ZA vêm sendo pressionada pela expansão urbana e agrícola da região, comprometendo a sua integridade ecossistêmica.

Figura 16. Imagem de satélite com zoom para a Estação Ecológica de Ribeirão Preto (EERP), delineado pela cor laranja.

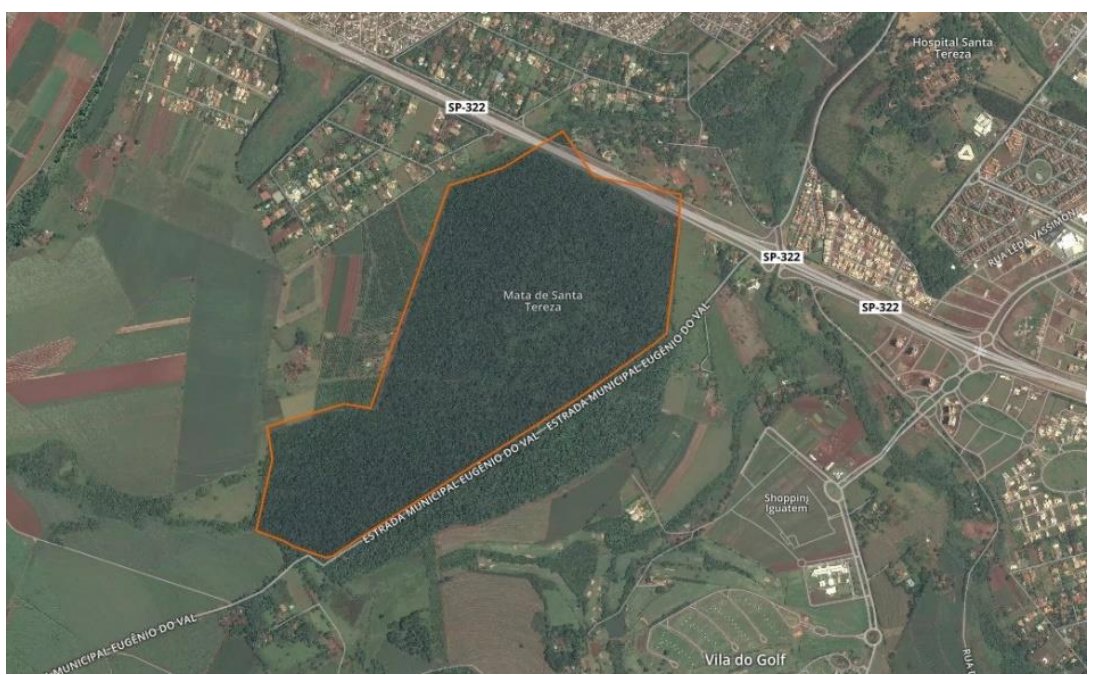

Fonte: IUCN e UNEP-WCMC (2015). 
A EERP localiza-se na bacia hidrográfica do Rio Pardo (UGRHI 4) e sua ZA (figura 17) é delimitada pelas bacias dos Córregos do Horto e Serraria, totalizando 2.681,71 ha. Os limites da ZA foram estabelecidos seguindo um raio de $10 \mathrm{~km}$ como ponto de partida, através da interpretação espacial do uso da terra e cobertura vegetal, diagnósticos, identificação dos vetores de pressão sobre o território, estudo do Plano Diretor do município de Ribeirão Preto e meio biótico do entorno da UC (LEONEL; NALON; THOMAZIELLO, 2010).

Figura 17. Zona de Amortecimento da Estação Ecológica de Ribeirão Preto (EERP).

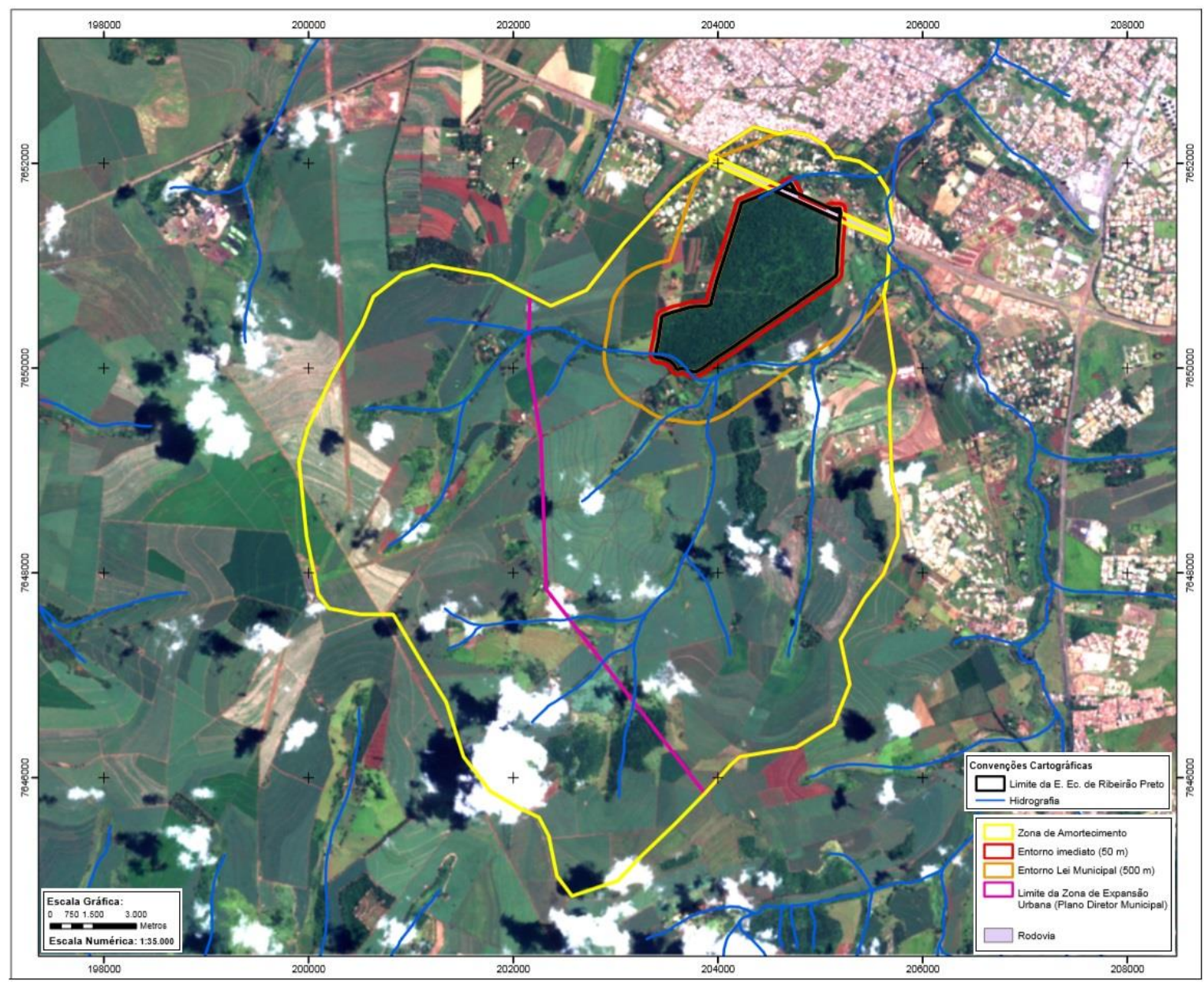

Fonte: Leonel, Nalon e Thomaziello (2010).

O zoneamento interno da EERP (figura 18) é composto por cinco zonas: primitiva, recuperação, uso conflitante e extensivo, uso especial e uso extensivo. As zonas possuem normas e restrições específicas, de acordo com os seus objetivos de conservação, elaboradas durante a criação do Plano de Manejo. 
Figura 18. Zoneamento intero da Estação Ecológica de Ribeirão Preto (EERP).

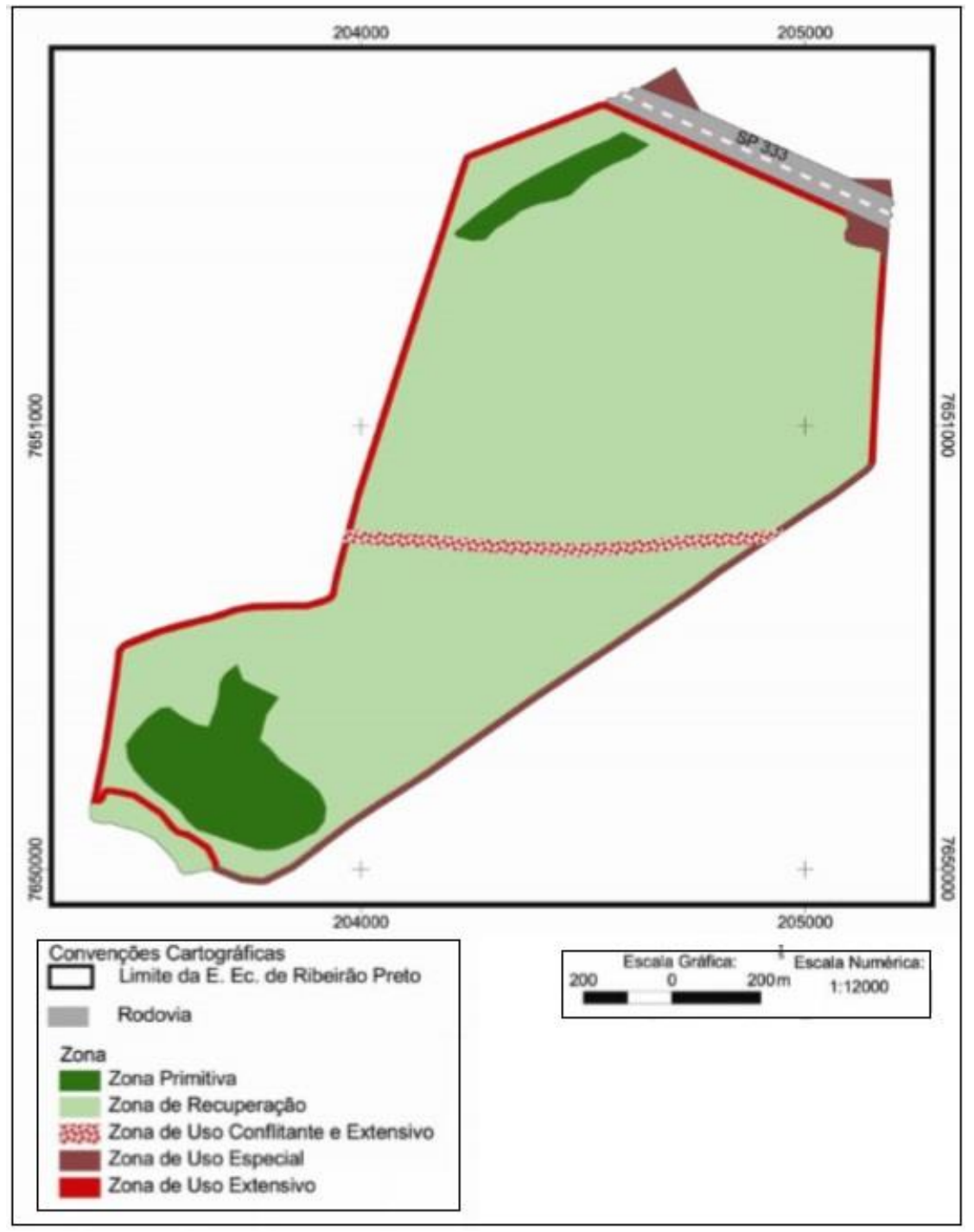

Fonte: Leonel, Nalon e Thomaziello (2010).

O Plano de Manejo da EERP realizado em 2011 é considerado adequado pela sua gestão, onde houve o envolvimento da comunidade durante as oficinas participativas. Contudo, atualmente se observa que a interação com a comunidade do entorno está restrita as atividades de educação ambiental dentro da UC, bem como a sua participação é limitada através das Reuniões de Conselho, as quais são realizadas para o atendimento das demandas das câmaras técnicas. No entanto, a gestão alega que não foram verificadas reuniões do Conselho Consultivo durante o ano de 2016. Além disso, as oficinas apontaram que a população em geral desconhece que a Mata é uma ESEC e sua correlata legislação ambiental. Isso se deve muito provavelmente pelo fato de não existir um material de divulgação (e.g. site interativo, cartilha educativa) para a EERP, contendo a sua 
caracterização e importância como patrimônio natural e para a conservação da biodiversidade, havendo apenas informações usuais no site da FF, as quais estão desatualizadas desde 2011. A consulta de informações sobre a EERP no CNUC também está desatualizada, e não contém informações de cunho biológico e social. Ademais, não foram verificadas estratégias de divulgação e comunicação em mídias sociais. Contudo, quando a gestão necessita divulgar alguma informação importante que envolve a UC, ela ocorre através da mídia local (jornal, rádio e TV).

Em relação aos recursos humanos e financeiros, verifica-se que a gestão considera-os adequados para o manejo adequado da UC. Isso pode ser explicado pelo seu orçamento anual, o qual foi cerca de oito vezes maior que o menor orçamento observado para as demais UCs do presente estudo.

\subsubsection{Pressões e Ameaças ${ }^{43}$}

As principais pressões e ameaças à EERP são identificadas e avaliadas pela gestão segundo um grau de intensidade (figura 19), comentadas a seguir.

Figura 19. Principais pressões e ameaças da EERP. As pressões e ameaças avaliadas como severas possuem pontuação entre 25 a 64, as altas possuem pontuação entre 10 a 24 pontos, as moderadas entre 4 a 9 pontos e as leves possuem de 1 a 3 pontos.

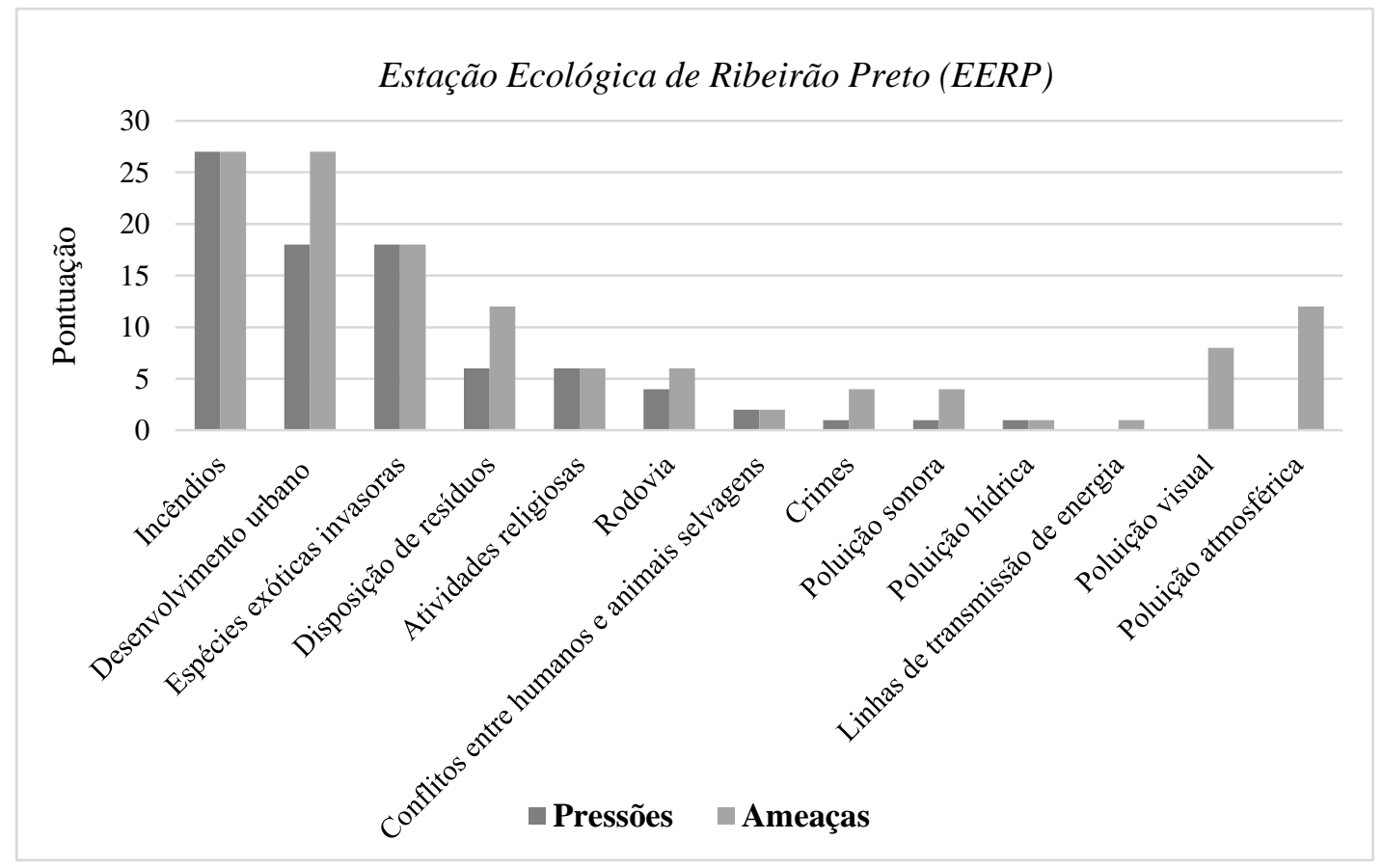

Fonte: Elaborado pela autora (2016), a partir das informações fornecidas pela gestão.

\footnotetext{
${ }^{43}$ Apêndice V.
} 
Pressõe severas:

A única pressão severa (pontuação de 25 a 64) avaliada pela gestão são as ocorrências de incêndios (27 pontos), os quais aumentaram drasticamente nos últimos cinco anos. De acordo com Kotchetkoff-Henriques (2003), o município de Ribeirão Preto possui 3,9\% de vegetação natural, distribuídos em 102 remanescentes florestais. Segundo a autora, a maioria dos fragmentos são pequenos e isolados e, muitos daqueles com elevado valor de conservação situam-se em área de expansão urbana, e portanto, estão mais sujeitos a pressões antrópicas. É nesse contexto que encontra-se a EERP, inserida em uma região onde o desmatamento proveniente da expansão agrícola e urbana chegou a ocupar $75 \%$ do município no ano 2000 (LEONEL; NALON; THOMAZIELLO, 2010).

Como resultado, o isolamento da EERP de outros remanescentes florestais e os efeitos de borda, de maneira geral ocasionados pela fragmentação da região, tornam-a mais sujeita a ocorrência de incêndios. Os incêndios florestais ocorrem na maioria das vezes em decorrência de trabalhos religiosos e da proximidade com a área urbana. Em 2014, houve um incêndio de grande magnitude, atingindo uma área de aproximadamente 70 ha (figura 20). Segundo a gestão, o primeiro incêndio foi causado por velas acesas na ZA, provenientes de um ritual religioso, ao passo que os demais foram motivados pela baixa umidade relativa do ar. Desse modo, verifica-se que a Mata encontra-se em estado muito degradado, ainda a espera da implantação de um plano de recuperação, o qual está parado em meio a burocracias do órgão gestor.

Figura 20. Imagem de satélite da EERP após o incêndio (data: 14/12/2014).

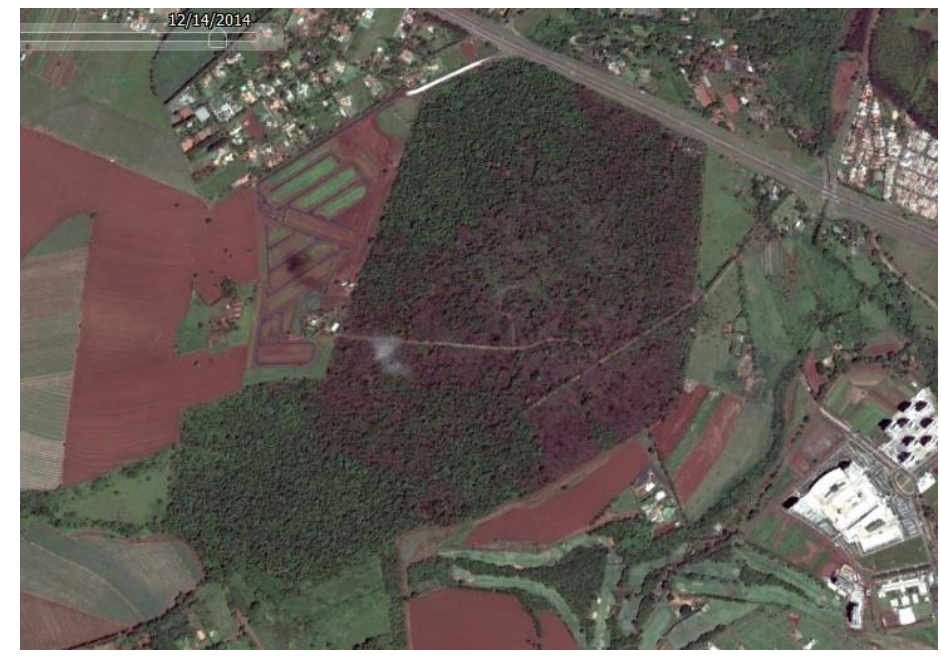

Fonte: Google Earth (2016). 


\section{Pressões altas:}

As pressões avaliadas pela gestão como altas (pontuação de 10 a 24) e que aumentaram drasticamente nos últimos cinco anos são: desenvolvimento urbano e espécies exóticas invasoras, ambas com 18 pontos.

É importante ressaltar que, durante as últimas décadas, a região de Ribeirão Preto se tornou uma das mais ricas do Estado de São Paulo e encontra-se em franco crescimento, com o $27^{\circ}$ maior PIB brasileiro e declarada em 2010 como "pólo tecnológico" (PREFEITURA MUNICIPAL DE RIBEIRÃO PRETO, 2016). Grande parte desse alto desempenho se deve a agricultura, onde a qualidade dos solos (terra roxa) e do clima fazem com que esta seja uma das principais regiões agrícolas do país, caracterizando-se por uma grande produção e por elevados níveis de rendimento das culturas (PREFEITURA MUNICIPAL DE RIBEIRÃO PRETO, 2016). Além disso, a região é produtora mundial de açúcar e álcool, sendo as usinas uma das principais atividades econômicas da região (PREFEITURA MUNICIPAL DE RIBEIRÃO PRETO, 2016). Como consequência, o desenvolvimento e a expansão agrícola vêm pressionando a UC e o seu entorno.

Segundo o Plano Diretor de Ribeirão Preto (Lei Municipal no 501, 01/12/1995), a EERP está localizada em Zona de Urbanização Controlada, em perímetro de expansão urbana, próxima ao núcleo urbano de Ribeirão Preto (mapa plano diretor). O uso do solo urbano no seu entorno é caracterizado pela presença de uma Rodovia (Anel Viário de Ribeirão Preto), bairros, loteamentos, condomínios e áreas de lazer. Assim, o forte adensamento urbano decorrente da alta demanda para implantação de novos empreendimentos urbanos vem pressionando a EERP e sua ZA.

Em relação ao estabelecimento de espécies exóticas invasoras, de maneira geral, as espécies de flora que se destacam pelo seu alto potencial invasor são as gramíneas africanas (e.g. braquiárias - Urochloa decumbens, capim-colonião - Panicum maximum, capim-napier Pennisetum purpureum). Essas espécies se proliferam conforme o revolvimento do solo na manutenção dos aceiros, e invadem ambientes sem cobertura florestal, normalmente nas áreas de borda. Além disso, verifica-se a frequente presença de cães domésticos (Canis lupus familiaris) dentro da Mata, os quais tornam-se predadores das espécies nativas e potenciais transmissores de doenças.

\section{Pressões moderadas:}

As pressões avaliadas como moderadas (pontuação de 4 a 9) pela gestão da EERP e que aumentaram ligeiramente nos últimos cinco anos são: disposição irregular de resíduos (6 pontos) e 
a presença de uma Rodovia, em área limítrofe à EERP (4 pontos). Além disso, outra pressão moderada são as atividades religiosas (6 pontos), as quais permaneceram constantes nos últimos cinco anos.

Em relação à disposição irregular de resíduos, observa-se que a maioria destes sãos provenientes da construção civil e de materiais de poda, descartados ao longo da Rodovia e nas áreas limítrofes à EERP. Já as atividades religiosas se devem pela proximidade com a área urbana, tornando a EERP um local de fácil acesso aos praticantes de cultos religiosos, atividades que resultam na deposição de resíduos no interior da Mata e potencializam os riscos de incêndios, através do uso de materiais inflamáveis. Conforme mencionado anteriormente, a causa do incêndio florestal na Mata de 2014 foi decorrente de velas acesas no entorno da UC, provenientes de um ritual religioso.

A presença de uma Rodovia (Rodovia Prefeito Antônio Duarte Nogueira, SP-322, também conhecida como Anel Viário Contorno Sul) na divisa da EERP (porção nordeste) também é considerada como uma pressão à UC, apesar de nos últimos cinco anos não terem se estabelecido novas estradas e rodovias no entorno imediato da EERP. Contudo, verifica-se um aumento do fluxo de veículos motorizados na região, trazendo impactos à Mata. Além disso, a UC é cortada no sentido leste-sul pela Estrada Eugênio do Val, a qual foi desativada por determinação judicial no fim de 2012. Desse modo, existem ocorrências de atropelamentos da fauna silvestre nos últimos cinco anos, principalmente com espécies de répteis.

\section{Pressões leves:}

As pressões avaliadas pela gestão como leves (pontuação de 1 a 3 ) e que permaneceram constantes nos últimos cinco anos são os conflitos entre humanos e animais selvagens (2 pontos). A pressão leve que aumentou ligeiramente nos últimos cinco anos é poluição sonora (1 ponto), ao passo que as pressões leves que diminuíram drasticamente são as ocorrências de crimes no interior da área protegida (1 ponto) e a poluição hídrica (1 ponto).

Os conflitos entre humanos e animais selvagens ocorrem quando há visitação espontânea irregular ao longo da estrada municipal que margeia a EERP e a corta, de pessoas interessadas em ver e interagir (fornecer alimentos) com os macacos-prego. Além desse conflito, existem casos esporádicos de atropelamento de fauna (e.g. répteis em geral).

Em relação a ocorrências de crimes no interior da Mata, essa atividade diminuiu drasticamente nos últimos cinco anos, após a desativação da Estrada Eugênio do Val em 2012. 
Segundo a gestão, verificava-se o abandono e queima de veículos motorizados. Apesar de ser uma pressão leve, é avaliada como uma ameaça moderada, visto o avanço da cidade em direção à Mata, aumentando assim os riscos de incidentes e crimes na região.

Outra pressão avaliada como leve à EERP pela gestão é a poluição sonora, proveniente da proximidade das vias de acesso (e.g. fluxo de veículos motorizados). Atualmente não há registros de que essa atividade esteja trazendo impactos altos para a Mata. Contudo, com o aumento do fluxo de veículos motorizados nos próximos anos, será uma ameaça moderada à EERP.

Em relação aos recursos hídricos da EERP, ela está inserida na microbacia do Córrego da Serraria e do Córrego do Horto, ambas sub-bacias do Ribeirão Preto. Nesse contexto, de acordo com a opinião do gestor, a poluição hídrica dos corpos d'água que compõem a ZA da Mata tem sido uma pressão e ameaça leve à EERP e vem diminuindo drasticamente nos últimos cinco anos.

\section{Ameaças:}

Além das pressões e ameaças comentadas anteriormente, existem atividades que não foram consideradas como prejudiciais à EERP atualmente, mas que poderão trazer um impacto prejudicial à UC nos próximos cinco anos, tais como: poluição atmosférica (12 pontos), poluição visual (8 pontos) e o estabelecimento de LTs ( 1 ponto). De maneira geral, acredita-se que com o avanço da expansão urbana e suas implicações (e.g. aumento da ocupação urbana, fluxo de veículos motorizados e consumo de energia), essas atividades possam trazer impactos negativos para à EERP nos próximos cinco anos.

Por fim, dos 13 tipos de pressões e ameaças identificadas, 8 irão aumentar em algum nível de intensidade. Segundo a gestão, isso ocorre devido à EERP estar na rota de expansão da cidade, sendo cada vez mais cercada pelo desenvolvimento urbano do município e as atividades de interesse público, as quais vêm comprometendo a integridade da UC durante os últimos anos.

\subsection{Estação Ecológica de Assis (EEcA)}

A Estação Ecológica de Assis (figura 21) também compõe o grupo de UCs de Proteção Integral do Estado de São Paulo, com objetivos de preservação da natureza, pesquisas científicas e educação ambiental, sendo administrada pelo Instituto Florestal da Secretaria do Meio Ambiente do Estado de São Paulo (IF).

Seu território é de 1.760,64 ha e localiza-se no município de Assis. Foi criada a partir do Decreto Estadual n³5.697, de 21/09/1992 e posteriormente ampliada pelo Decreto Estadual 
nº7.097, de 18/09/2002. Ademais, a UC encontra-se inserida na bacia hidrográfica do Médio Paranapanema (VGRI - 17).

A EEcA, antigo Horto Florestal de Assis, situa-se nas áreas mais altas de Assis (entre 500 e $588 \mathrm{~m}$ ), protegendo as nascentes do principal manancial de abastecimento público do município. Além disso, é um dos maiores fragmentos de vegetação natural da região, abrigando espécies e processos biológicos do Cerrado e de Floresta Estacional Semidecidual.

Figura 21. Imagem de satélite da Estação Ecológica de Assis (EEcA), delineada pela cor laranja.

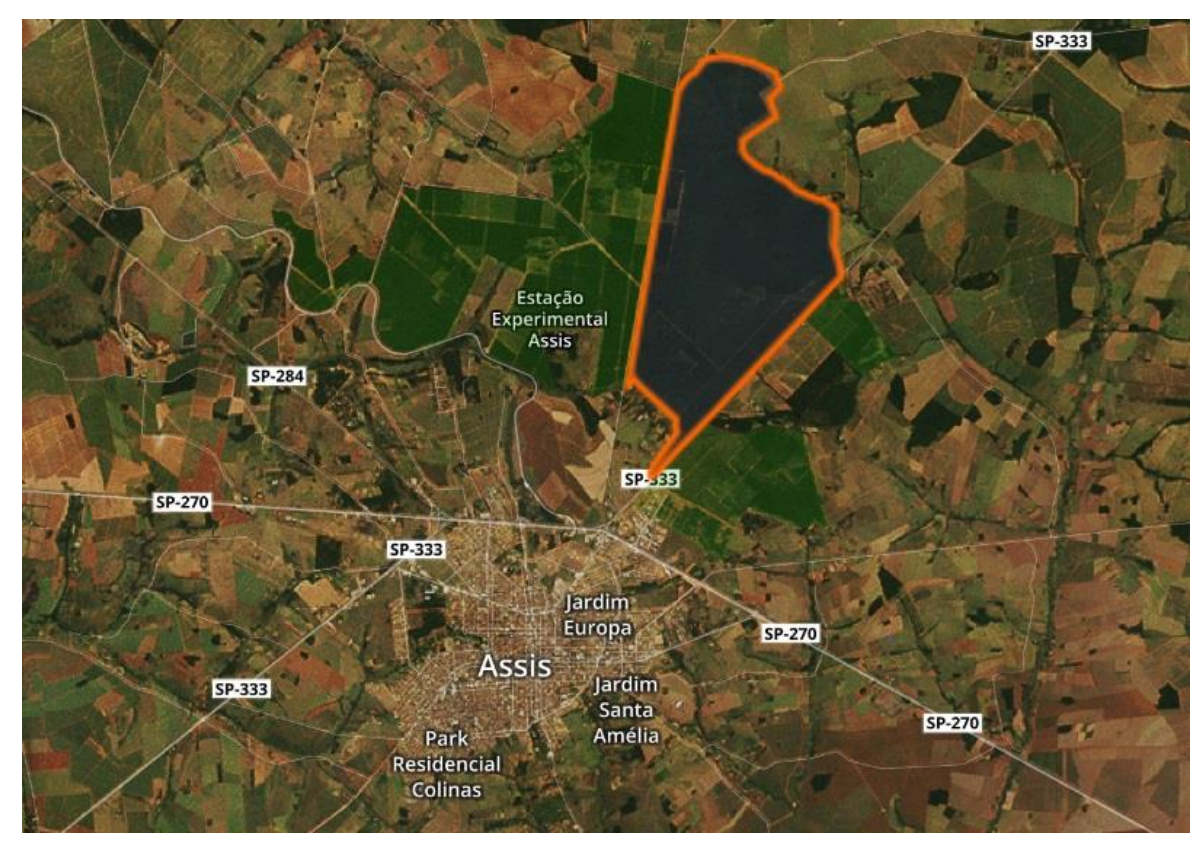

Fonte: IUCN e UNEP-WCMC (2015).

Contudo, vem sendo pressionada e ameaçada pelos usos atuais do seu entorno, predominantemente pela expansão agrícola (e.g. cana-de-açúcar, cultura anual, pastagem, reflorestamento) e urbana (e.g. chácaras, residências, estradas e rodovias). Logo, a UC possui alta relevância pois preserva espécies de fauna e flora regionais, bem como um número significativo de espécies ameaçadas de extinção em um município carente de áreas naturais públicas.

Em relação aos mecanismos de participação da sociedade civil na EEcA, verifica-se que ela ocorre apenas através do Conselho Consultivo e Conselhos Municipais. Não existem grupos de apoio e voluntários para a realização de ações de educação ambiental ou auxílio no manejo. Segundo a gestão, alguns anos atrás eram promovidos eventos culturais (e.g. exposições de arte e artesanato) e palestras nas escolas (sistemáticas, cursos ou datas comemorativas), os quais eram 
divulgados pela imprensa regional. Contudo, atualmente as atividades socioeducativas na EEcA não são realizadas por falta de funcionários e pelos riscos de febre maculosa no local ${ }^{44}$. Nesse contexto, também verifica-se que apesar da comunidade apoiar os objetivos da UC, grande parte não diferencia a Estação Ecológica da Floresta Estadual, o que demonstra a ausência de um maior fortalecimento da identidade da EEcA.

A ZA da EEcA (figura 22) abrange o município de Assis e uma pequena proporção do município de Paraguaçu Paulista. Ela foi definida levando-se em consideração toda a área da Floresta Estadual de Assis, da Estação Experimental do Instituto Agronômico de Campinas, das sub-bacias e microbacias hidrográficas que se delimitam com a Estação Ecológica de Assis. Segundo Durigan (2010), os principais conflitos desta zona é a presença de um aterro sanitário, a expansão urbana, conversão de uso da terra, fauna doméstica e queima de cana-de-açúcar.

Figura 22. Zona de Amortecimento da Estação Ecológica de Assis (EEcA).

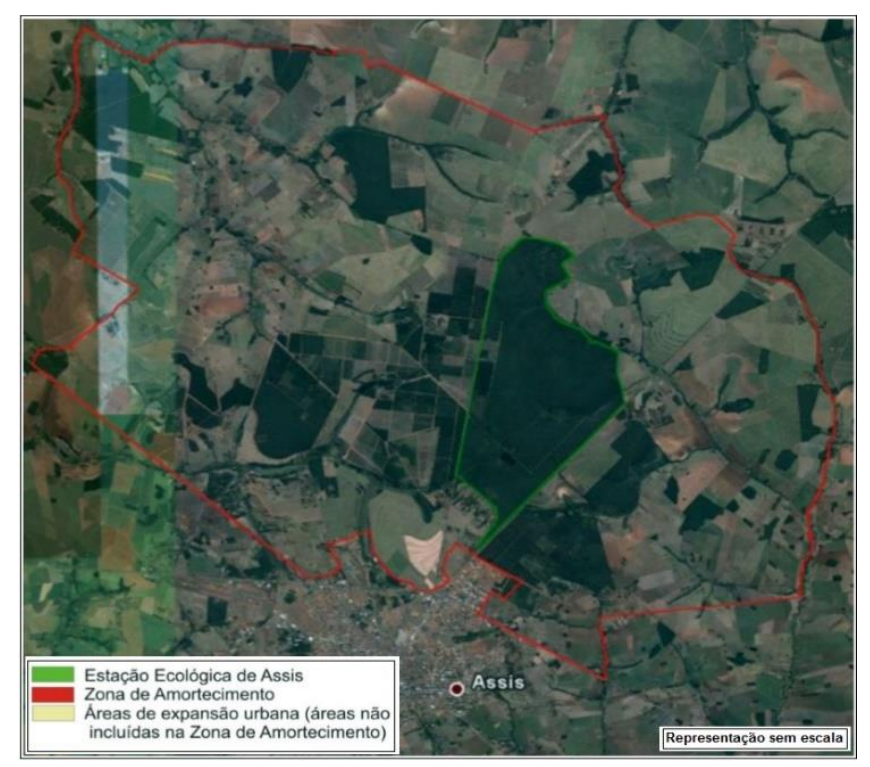

Fonte: Durigan (2010).

Já o zoneamento interno da Estação (figura 23) é composto por três zonas (zona primitiva, de recuperação e de uso especial), que possuem normas e diretrizes específicas, definidas durante a elaboração do Plano de Manejo (DURIGAN, 2010).

\footnotetext{
${ }^{44}$ Segundo a gestão, existem atividades de educação ambiental com as escolas do município no Centro de Educação Ambiental da Floresta Estadual de Assis, mas sem regularidade. Não há mais eventos comemorativos.
} 
Figura 23. Zoneamento interno da Estação Ecológica de Assis (EEcA).

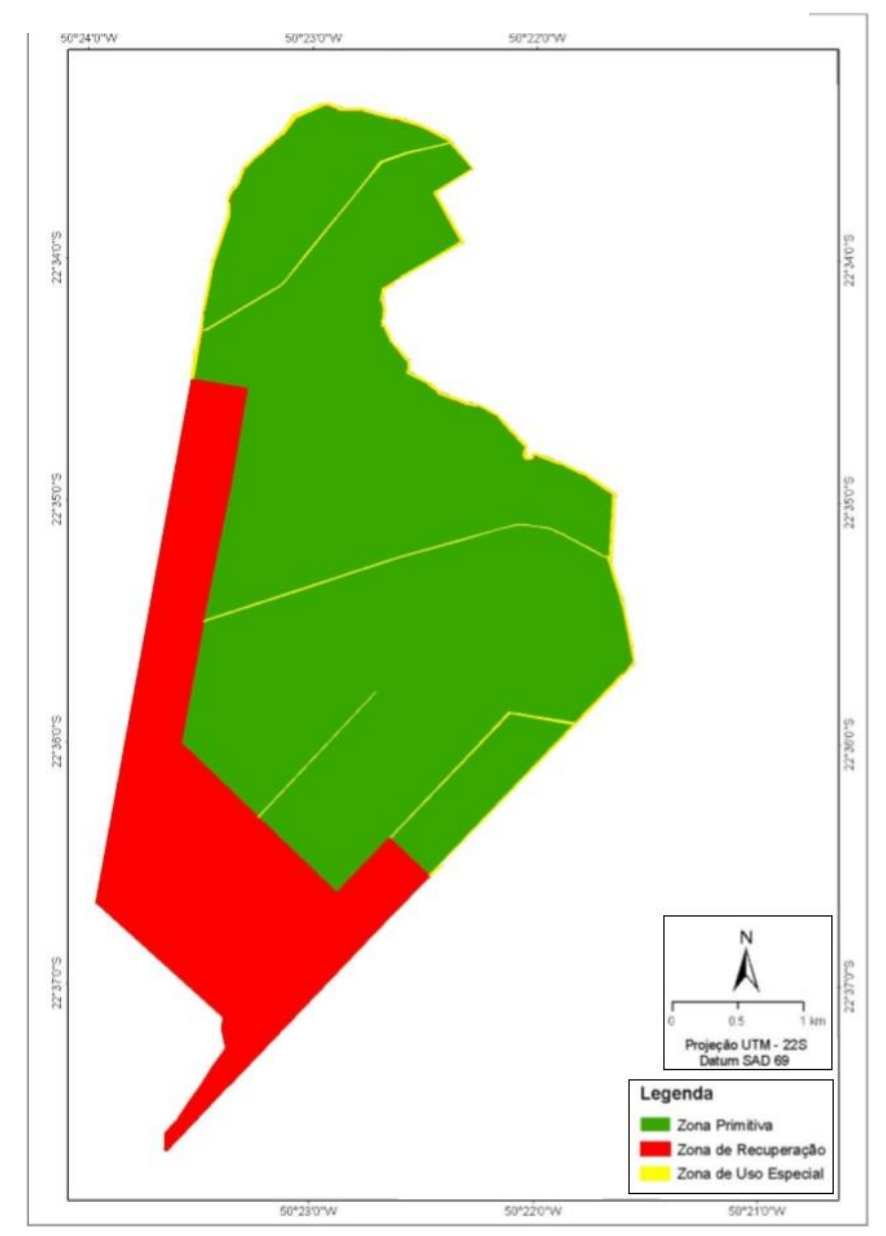

Fonte: Durigan (2010).

No que se refere aos meios de divulgação da área, verifica-se a comunicação de informações importantes relacionadas a EEcA através da mídia local (jornal, rádio e TV). A UC também possui uma página no website do IF, e no CNUC, ambas contendo informações atualizadas ao público. Ademais, não existe um site interativo e nem a divulgação de informações em mídias sociais.

No tocante aos recursos humanos, a situação se agrava. A gestão adverte que existe uma carência de funcionários em todos os níveis para o manejo adequado da UC e o cumprimento dos Programas de Manejo. Além disso, não possuem habilidades ou oportunidades de capacitação e desenvolvimento apropriadas às suas necessidades.

De maneira geral, a UC compartilha recursos materiais e humanos com a Floresta Estadual de Assis, os quais são quase sempre insuficientes para atender as necessidades básicas. A gestão também alega que os recursos financeiros não foram adequados para realizar as ações de manejo 
críticas dos últimos cinco anos, bem como não há previsão estável a longo prazo para a UC. Desse modo, a gestão vem buscando recursos advindos de compensações ambientais e parcerias como solução para a implementação dos Planos de Manejo.

\subsubsection{Pressões e Ameaças ${ }^{45}$}

As principais pressões e ameaças da EEcA foram identificadas e avaliadas pela gestão durante a entrevista, segundo um grau de intensidade (figura 24).

Figura 24. Principais pressões e ameaças da EEcA. As pressões e ameaças avaliadas como severas possuem pontuação entre 25 a 64, as altas possuem pontuação entre 10 a 24 pontos, as moderadas entre 4 a 9 pontos e as leves possuem de 1 a 3 pontos.

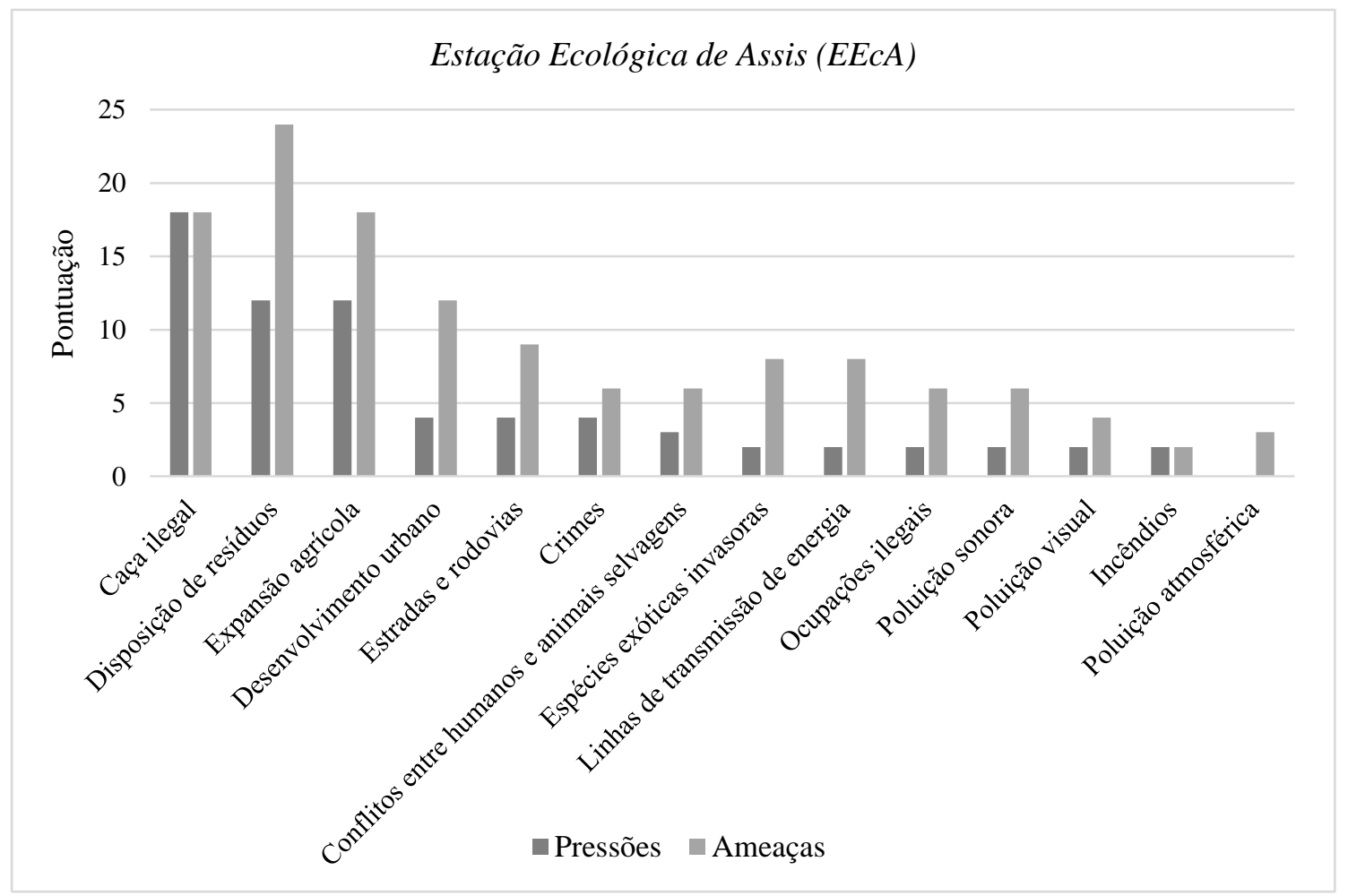

Fonte: Elaborado pela autora (2016), a partir das informações fornecidas pela gestão.

\section{Pressões altas:}

As pressões avaliadas como altas (pontuação de 10 a 24) e que permaneceram constantes nos últimos cinco anos são: caça ilegal (18 pontos) e disposição irregular de resíduos (12 pontos). Além dessas, verifica-se a expansão agrícola (12 pontos), a qual aumentou ligeiramente nos últimos cinco anos.

\footnotetext{
${ }^{45}$ Apêndice VI.
} 
De acordo com a gestão, embora existam vigilantes e fiscalização diária, a caça ilegal de animais silvestres ocorre dentro da EEcA, onde eventualmente são encontrados indícios de caçadores no interior da UC, os quais praticam a caça ilegal de algumas espécies, tais como veadocatingueiro (Mazama guazoubira), catetos (Pecari tajacu) e passarinhos em geral. Desse modo, a gestão acredita que essa atividade continuará a ocorrer nos próximos cinco anos.

Em relação à disposição irregular de resíduos, ela ocorre na ZA da UC. Segundo a gestão, existe um aterro sanitário localizado próximo ao limite noroeste da área. Apesar do aterro estar atualmente inativo, a Prefeitura do município ainda não cumpriu com as ações exigidas pela CETESB e determinadas pelo Ministério Público para encerrar formalmente o aterro. Para piorar, existe uma estação de transbordo junto ao limite da ZA da EEcA com o Distrito Industrial da cidade, potencializando os riscos de transmissão de doenças e contaminação dos corpos d'água da região. Além disso, verifica-se o descarte irregular de resíduos ao longo das estradas e rodovias próximas à unidade. Desse modo, com o aumento do fluxo de pessoas e veículos nas proximidades da UC, é alta a probabilidade dessa pressão se intensificar nos próximos anos.

A expansão agrícola da região do entorno da EEcA, em especial a conversão de pastagens em agricultura (e.g. cana-de-açúcar e culturas anuais), é considerada preocupante, sobretudo pela tendência ao aumento do desmatamento e corte de árvores isoladas, inadequação do uso do solo agrícola, erosão e assoreamento dos corpos d'água, disposição inadequada de resíduos e pelo baixo índice de cobertura florestal no entorno da UC.

\section{Pressões moderadas:}

As pressões avaliadas como moderadas (pontuação de 4 a 9) e que aumentaram drasticamente nos últimos cinco anos são: desenvolvimento urbano e estradas e rodovias, ambas com 4 pontos. Além disso, verificam-se ocorrências de crimes (4 pontos), os quais permaneceram constantes nos últimos cinco anos.

A EEcA encontra-se na rota de expansão urbana da cidade de Assis, com área urbanizada consolidada ao sul da UC. Desse modo, o desenvolvimento urbano na região (e.g presença de residências, condomínios, comércio, distrito industrial e rodovias) aumentou drasticamente nos últimos cinco anos, sendo uma pressão e uma ameaça alta à EEcA. Também existe uma pressão constante dos proprietários do entorno para se diminuir a ZA na próxima atualização do Plano de Manejo. Para agravar a situação, não foi verificado nenhum tipo de articulação com o município 
para se aumentar as áreas verdes na região do entorno da EEcA, prevendo a conectividade da paisagem com a formação de corredores entre a UC e outros fragmentos de cerrado na região.

Nesse contexto, a EEcA está cercada por duas rodovias vicinais pavimentadas, a Rodovia Assis - Lutécia (ou Estrada da Lutécia) e a Rodovia Rachide Rayes (SP-333). Além disso, existe a presença de uma ferrovia na ZA, que oferece as mesmas ameaças, mas em menor intensidade. Segundo a gestão da ESEC, houve um aumento drástico no fluxo de veículos motorizados nas vias de acesso nos últimos cinco anos, sendo uma pressão e ameaça moderada à UC. Os impactos ocasionados são diversos, tais como o aumento de riscos de incêndios, atropelamentos da fauna silvestre, invasões e processos erosivos.

Também verifica-se a ocorrência de crimes, geralmente nas divisas da EEcA próximo às rodovias, tais como assassinatos, abandono e queima de veículos motorizados, uso de substâncias ilícitas, ocultamento de produtos roubados, entre outros. De acordo com a gestão da EEcA, esses crimes ocorrem em diferentes locais, apesar de haver rondas diárias dos vigilantes, sendo uma ameaça moderada à UC.

\section{Pressões leves:}

As pressões avaliadas como leves (pontuação de 1 a 3) e que aumentaram ligeiramente nos últimos cinco anos são os conflitos entre humanos e animais selvagens (3 pontos) e o estabelecimento de LTs (2 pontos). As pressões leves que diminuíram ligeiramente nos últimos cinco anos são as espécies exóticas invasoras ( 2 pontos), incêndios ( 2 pontos) e as ocupações ilegais (2 pontos). Já as pressões leves que permaneceram constantes nos últimos anos são a poluição sonora e visual (2 pontos).

Verificam-se atropelamentos da fauna nas estradas e rodovias do entorno, bem como animais silvestres (e.g. onça parda) predando animais domésticos ou de criação (e.g. gado, ovelhas) das propriedades vizinhas a EEcA, os quais são caracterizados como conflitos entre humanos e animais selvagens (fauna silvestre).

Em relação às espécies exóticas invasoras, a gestão alega que o problema mais sério foi controlado, que era a presença de Pinus sp. nas zonas ao redor das nascentes. Outro problema era a presença de gramíneas africanas invasoras (e.g braquiária), as quais se estabelecem em fisionomias abertas de Cerrado. Contudo, pelo fato dessas fisionomias estarem desaparecendo com o passar dos anos pela política de conservação de supressão de fogo, então a braquiária não é mais considerada como um problema à EEcA. Apesar de haver um manejo periódico, algumas espécies 
persistem em pontos localizados, como o pinus e o lírio-do-brejo. Além das espécies de flora, existem cães e gatos domésticos, os quais geralmente são abandonados por seus donos na UC, e passam a caçar a fauna silvestre.

Outra pressão observada na ZA da UC é o estabelecimento de LTs, as quais pertencem à Empresa de Distribuição de Energia Elétrica Vale Paranapanema - ENERGISA. Desse modo, a gestão acredita que essa pressão irá se intensificar nos próximos anos, visto o aumento da demanda de energia.

Além desses problemas, existe o parcelamento ilegal do solo no entorno da EEcA por chácaras e condomínios. O que se observa é a venda de terrenos ilegais, sem escrituras, ocasionando em graves conflitos entre os proprietários que adquiriram os terrenos e a gestão da UC, que vem fiscalizando a ZA. Além disso, em 2014 houve a invasão de um grupo de assentados do Movimento dos Trabalhadores Rurais Sem Terra (MST) próximo a divisa com a EEcA, na Floresta Estadual de Assis. Desse modo, apesar de todos os esforços adotados pela gestão para mitigar esse problema, a probabilidade dessa pressão aumentar nos próximos anos é alta.

Outras pressões avaliadas como leves são a poluição sonora e visual. Segundo a gestão, elas ocorrem devido ao fluxo de veículos motorizados nas vias de acesso próximas a EEcA, bem como proveniente das luzes noturnas artificiais do entorno.

Em relação aos incêndios florestais, apesar desses eventos estarem diminuindo ao longo dos últimos anos, são originados principalmente nas margens das rodovias próximas a UC, áreas mais susceptíveis à propagação do fogo. No entanto, a gestão da ESEC ressaltou a necessidade da realização do manejo controlado do fogo, por se tratar de uma UC de Cerrado. Embora o Art. 38 da Lei 12.651 de 25 de maio de 2012 preveja o emprego da queima controlada em UCs, visando o manejo conservacionista da vegetação nativa com características ecológicas associadas evolutivamente à ocorrência de fogo, o Plano de Manejo vigente não menciona esta prática de manejo, pondo em risco a integridade da área.

Segundo a gestão da EEcA, com o avanço da expansão urbana e agrícola em direção à UC nos próximos anos, espera-se portanto um aumento considerável dos impactos à UC para todas as pressões mencionadas. Nesse sentido, outro evento que espera-se ocorrer é a poluição atmosférica. Embora atualmente a emissão de poluentes dos veículos motorizados que circulam nas rodovias próximas à EEcA não estarem trazendo impactos significativos para a UC (segundo a opinião da gestão da unidade), haverá um aumento considerável nos próximos cinco anos. 
Por fim, dos 14 tipos de pressões e ameaças identificadas, verifica-se um aumento do grau de intensidade em 12 tipos nos próximos cinco anos. Conforme mencionado anteriormente, a EEcA encontra-se na rota de expansão do município de Assis, e portanto alvo dos impactos prejudiciais resultantes da expansão urbana.

\subsection{Ações de Conservação}

Nos planos de manejo, verificam-se programas de manejo, definidos durante o processo de planejamento operacional de cada área. Os programas de manejo reúnem diversas linhas de ações e diretrizes, a serem implementados durante o ciclo de gestão, visando a mitigação dos principais problemas enfrentados por essas áreas, bem como para que elas alcancem a sua visão, cumpram com sua missão e objetivos específicos. Ademais, as ações devem ser constantemente avaliadas e aprimoradas, conforme forem surgindo novos desafios (FERNANDES; HANGAE; MOTA, 2011).

Desse modo, observa-se que todas as UCs do presente estudo buscaram implementar algum tipo de ação de conservação para as pressões as quais vêm sofrendo, identificadas anteriormente. Apesar de cada UC apresentar particularidades e objetivos distintos, grande parte das iniciativas implementadas por suas equipes de gestão se assemelham. Isso ocorre devido os seus órgãos gestores $(\mathrm{FF} \text { e IF })^{46}$ possuírem a mesma base de diretrizes, bem como por seguirem o Roteiro Metodológico de Planejamento. Este, foi criado em 2002 por Galante, Beserra e Menezes e é considerado um marco referencial de ordenamento, planejamento e gerenciamento das UCs do país. Em 2011, foi realizada uma revisão deste Roteiro por Fernandes, Hangae e Mota. ${ }^{47}$

Nesse sentido, segundo Trzyna (2014), existem inúmeros meios de se conservar a biodiversidade em áreas urbanas. Logo, o autor relata uma série de ações de conservação (diretas e indiretas) em áreas protegidas urbanas. De maneira lógica, ações de conservação diretas buscam atingir o status de conservação mais rapidamente, que tragam resultados mais diretos (e.g. promoção de conexões com outras áreas naturais, redução dos efeitos de ruídos e luzes artificiais), ao passo que as ações indiretas promovem a conservação de forma indireta, a longo prazo (e.g. educação ambiental e pesquisas científicas).

\footnotetext{
${ }^{46}$ A partir do Decreto Estadual $\mathrm{n}^{\circ}$ 51.453, de 29/12/06, fica estabelecido que os gestores do Sistema Estadual de Florestas (SIEFLOR) são a FF e o IF, seguindo objetivos de aperfeiçoar a gestão e a pesquisa na maior parte das UCs do Estado de São Paulo.

${ }^{47}$ Trata-se de uma versão para discussão e não é considerado um documento oficial pelo ICMBio.
} 
Desse modo, o presente tópico tem como objetivo analisar e discutir sobre as iniciativas que vêm sendo implementadas, de maneira conjunta, buscando identificar como esses órgãos vêm resolvendo seus principais problemas.

\section{Desenvolvimento urbano}

O desenvolvimento urbano foi avaliado como uma das pressões mais severas para os quatro casos de estudo da presente pesquisa, variando em grau de intensidade para cada caso. Além disso, observou-se que todas as UCs vêm sendo fortemente pressionadas para que haja uma flexibilização na suas ZAs (transformação das ZAs em ZEIS), principalmente para o estabelecimento de condomínios residenciais de alto padrão.

O principal amparo legal das UCs (BRASIL, 2000, Art. $2^{\circ}$ ) para impedir o avanço de atividades conflitantes com seus objetivos é a definição de uma ZA, estabelecida na criação do plano de manejo da UC. Trata-se de uma zona no entorno da UC, onde as atividades humanas estão sujeitas a normas específicas, com objetivos de diminuir os impactos negativos sobre a área. Para a sua definição, são consideradas legislações de planejamento territorial e de proteção ambiental municipal, estadual e federal, onde são listadas uma série de normas com restrições aos tipos de atividades a serem implantadas.

Ressalta-se que áreas localizadas dentro da ZA não podem ser transformadas em zonas urbanas (BRASIL, 2000, Art. 49 ${ }^{\circ}$ ), sendo o interior de uma UC e sua ZA são considerados legalmente como "zona rural” (COSTA et al., 2007). Logo, conforme discute Costa et al. (2007), são situações incompatíveis com a realidade das UCs urbanas, onde muitas se encontram totalmente inseridas na malha urbana, ou recebendo impactos indiretos das cidades, como é o caso das UCs do presente estudo.

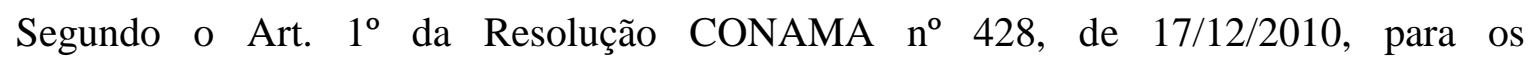
empreendimentos de significativo impacto ambiental que possam afetar as UCs e suas ZAs, serão concedidas licenças após autorização do órgão gestor da UC afetada. Desse modo, observou-se como prática comum a todos os casos de estudos a realização de manifestações através de pareceres técnicos, orientando-se as restrições e permissões nas sub-zonas para os processos de licenciamento de empreendimentos ou atividades que vierem causar impactos diretos ou indiretos mensuráveis na ZA (fora da Zona Urbana Consolidada).

A partir das manifestações elaboradas pelo chefe das UCs e os Conselhos Consultivos, vêm sendo possível barrar empreendimentos que não se adequam com as normas do plano de manejo. 
Este, é um instrumento imprescindível para a gestão de todas as UCs, mas especialmente das UCs urbanas, visto as crescentes pressões nos seus entornos.

Outra ação verificada em todas as UCs é a realização de articulações institucionais. Verifica-se o acompanhamento e participação da gestão das UCs e seus respectivos Conselhos Consultivos $^{48}$ nas discussões das políticas ambientais, de planejamento territorial dos municípios e a realização de parcerias informais. De maneira geral, os Conselhos são espaços de discussão onde os processos decisórios são compartilhados pelos indivíduos, através da formação das câmeras técnicas e encaminhamentos das demandas da área. Além disso, dada as fortes pressões para a flexibilização de suas ZAs, verifica-se que as equipes de gestão das UCs (com exceção da EERP) vêm buscando sensibilizar os diferentes atores envolvidos, explicando sobre os usos e restrições da ZA em fóruns de discussão do município. Contudo, as articulações variaram em intensidade nas diferentes UCs do presente estudo.

No caso do PEC, a sua equipe de gestão vem trazendo representantes das subprefeituras, lideranças comunitárias, ONGs, empresas, órgãos públicos estaduais e federais, de influência direta para o Parque no seu Conselho Consultivo. Durante a recente revisão do plano diretor do município de São Paulo, os membros do Conselho do PEC criaram um documento técnico informativo questionando as possíveis alterações na ZA, o qual foi entregue para todos os vereadores da cidade. Além disso, observa-se a participação do Conselho do Parque nas reuniões de planejamento do município, pressionando o setor público para conter a expansão de condomínios de alto padrão na sua ZA, no município de Mariporã.

Para o caso do PEJ, verifica-se uma mobilização das instituições representativas da UC na luta contra a transformação da ZEPAM em ZEIS, também através das reuniões do Conselho. Segundo o gestor, a transformação da zona ainda não foi decretada, pelo fato do Conselho ter apresentado fortes argumentos para se evitar o aumento da especulação imobiliária.

Já para a EEcA, a UC mantém parcerias com as instâncias tomadoras de decisão, tais como a Prefeitura Municipal, ONGs (e.g. FLORAVALE), Universidade Estadual Paulista Júlio de Mesquita Filho (UNESP, Campus de Assis), Fundações (e.g. Fundação Educacional do Município de Assis - FEMA) e associações do entorno. A partir das articulações e participações do Conselho,

\footnotetext{
${ }^{48}$ Os Conselhos Consultivos em UCs de Proteção Integral do Estado de São Paulo devem seguir as diretrizes do Decreto Estadual no 49.672, de 06/06/2005.
} 
foi possível transformar a ZA da UC em um status diferenciado no zoneamento territorial do município de Assis.

Quanto à EERP, apesar de haver um Conselho Consultivo com a participação de atores importantes do setor público (tais como: membros da Secretaria do Meio Ambiente, Prefeitura e representantes da sociedade civil), não houveram reuniões durante o ano de 2016, visto que a EERP deve reformular o seu Conselho Consultivo e passa por burocracias do órgão gestor. Desse modo, observa-se que a ausência de um fórum público de discussão dificulta as tomadas de decisões que envolvam a UC.

As equipes de gestão advertem que os Conselhos Consultivos ainda possuem desafios para serem efetivamente ativos, principalmente devido ao histórico do país em que as vontades políticas dos grandes setores de infraestrutura tendem a prevalecer sobre as questões ambientais. Mesmo assim, durante a participação nessas reuniões, busca-se de alguma forma contemplar algumas ações via Conselho.

Nesse contexto, outra forma de proteger as UCs das pressões externas, vêm sendo a execução de um programa de proteção, onde nele são realizadas ações de fiscalização e monitoramento por meio do programa da Secretaria Estadual de Meio Ambiente (SMA), o Sistema Integrado de Monitoramento (SIM). As ações de fiscalização ocorrem conforme o planejamento de cada UC e em conjunto com a Coordenadoria de Fiscalização Ambiental da SMA e Policiamento Ambiental.

Em relação aos impactos da fragmentação causada pelo desenvolvimento urbano, Saunders, Hobbs e Margules (1991) argumentam que existe uma grande necessidade em desenvolver uma abordagem integrada da paisagem, considerando as áreas protegidas no contexto da paisagem como um todo. Sabendo disso, a promoção de conectividade entre os fragmentos busca minimizar os efeitos negativos da fragmentação de habitat, melhorar o fluxo de genes das espécies, a dispersão da fauna, a viabilidade das populações e os serviços ecossistêmicos (LINDENMAYER; FRANKLIN; FISCHER, 2006). Desse modo, verifica-se algumas iniciativas para a promoção de conexões com outras áreas naturais no entorno das UCs do presente estudo, com exceção do PEJ.

Segundo a gestão do PEC, o Parque encontra-se altamente cercado pelo desenvolvimento urbano dos municípios abrangentes, com exceção das conexões com os Parques Estaduais de Itapetinga e Itaberaba. Apesar dessas limitações, a gestão vem buscando auxiliar na elaboração e 
implementação de parques lineares próximos ás áreas do Parque e entorno, onde alguns deles são projetos originários de compensação ambiental.

Já para a EERP, houve a criação de um Projeto de Recuperação Florestal de APP, conhecido como Projeto Conexão Verde, nas propriedades (públicas e particulares) localizadas na ZA (abrangendo parte da Zona de Urbanização Controlada e Zona Rural do município), durante a elaboração do seu plano de manejo em 2010, visando a recuperação e conservação de fragmentos existentes e o restabelecimento de conectividade para a conservação da UC. O Projeto foi uma parceria da gestão da EERP com o Centro de Extensão e Estudos Florestais da USP (CEEFLORUSP), e ainda encontra-se em andamento.

Em relação à EEcA, houve a ampliação dos seus limites territoriais por meio da aquisição de propriedades vizinhas (através de recursos de compensação ambiental pela construção das hidrelétricas Canoas I e II), bem como foram estabelecidas zonas de recuperação de grandes áreas contíguas a EEcA, resultando em considerável ampliação do habitat para a fauna silvestre no entorno da UC.

Por fim, para o PEJ, pelo fato do seu entorno ser totalmente urbano, a gestão adota uma postura de proteção da área, onde não foi observado o apoio e articulação da gestão na elaboração e implementação de projetos visando o desenvolvimento sustentável da região como um todo e das comunidades vizinhas.

\section{Estradas, rodovias e ferrovias}

Empreendimentos lineares de infraestrutura de transportes (e.g. rodovias, estradas e ferrovias) são considerados fundamentais para o desenvolvimento e progresso das cidades, trazendo benefícios sociais e econômicos para as regiões (ARROYAVE et al., 2006). Contudo, a implantação de projetos viários traz grandes impactos sobre o ambiente, tais como fragmentação dos ecossistemas, introdução de espécies exóticas, declínio de espécies nativas, alteração nos ciclos hidrológicos, climáticos, poluição sonora, poluição atmosférica e poluição dos solos (ARROYAVE et al., 2006).

Sabendo disso, verificam-se que as infraestruturas lineares são pressões para todos os casos de estudo, variando em grau de intensidade. Entre as UCs estudadas, os casos mais simbólicos foram observados no PEJ e no PEC, onde a presença de estradas, rodovias e ferrovias foram avaliadas como uma das pressões mais severas, contribuindo para a ruptura do contínuo florestal, 
indução de processos de ocupação urbana, potencializadores de atividades ilegais, contaminação por acidentes com cargas perigosas e perda da biodiversidade.

Para a implementação de projetos viários de significativos impactos ambientais é necessária a realização de estudos de impacto ambiental (EIA), devendo incluir medidas de prevenção, mitigação e compensação dos impactos gerados, as quais diferem conforme a complexidade, custo e eficácia das ações (ARROYAVE et al., 2006). Desse modo, verifica-se para todos os casos de estudos, a realização de manifestações através de pareceres técnicos, onde são orientados por parte da gestão da UC as restrições e permissões nas sub-zonas da área (Resolução CONAMA n ${ }^{428}$, Art. $1^{\circ}$ ). Como por exemplo, em relação a futura ferrovia que será implantada na região do PEC, a equipe fez uma manifestação preliminar ao licenciamento da obra através do Conselho Consultivo, como uma medida preventiva, solicitando a empresa responsável que enviasse documentos mais específicos sobre o empreendimento, para que assim seja possível se manifestar de maneira mais contundente sobre os impactos que acarretarão à UC.

Nesse contexto, existe uma série de ações para minimizar os impactos para a fauna silvestre, resultantes da implementação de projetos viários (e.g. cercas, sinalizações, refletores, passagens subterrâneas, viadutos, sistemas de iluminação, entre outros), onde a maioria dessas ações vêm sendo implementadas em alguns países desenvolvidos (e.g. Alemanha, França, Suíça e Holanda), os quais vêm monitorando a sua eficácia (ARROYAVE et al., 2006). Logo, sabendo desses fatos, e de que as infraestruturas lineares de transporte tem um impacto importante sobre as populações de animais selvagens e habitats naturais (TROCMÉ, 2006), considera-se no presente trabalho que a conectividade paisagística é vital para permitir o intercâmbio entre populações.

Em relação aos planos de manejo das UCs, a responsabilidade das concessionárias na instalação e manutenção periódica, nas estradas e acessos às suas estruturas e equipamentos, de placas informativas sobre a UC e as restrições de acesso e permanência nesses locais; o planejamento de soluções de passivos ambientais em relação às UCs, especialmente em casos de atropelamentos; adoção de novas medidas mitigadoras para equacionar a perda de animais silvestres; adoção de medidas de monitoramento de atropelamento na rodovia e estradas associadas.

Das ações de conservação observadas, verificaram-se algumas ações externas às equipes de gestão das quatro UCs, medidas de compensação ambiental implementadas pelas concessionárias responsáveis pelas estradas e rodovias (e.g. AutoBan, Desenvolvimento Rodoviário S/A - DERSA, 
Vianorte), a instalação de redutores de velocidade e sinalização nas vias de acesso próximas às UCs. Contudo, para à EEcA, ressalta-se que essas medidas somente foram implantadas após forte pressão e mobilização da gestão da UC no Conselho Municipal de Defesa ao Meio Ambiente (CONDEMA), para que o Departamento de Estradas de Rodagem (DER) realizasse ações de mitigação para os casos de atropelamento de fauna, os quais vêm aumentando progressivamente nos últimos cinco anos. Já para a EERP, além dessas ações, verificou-se o plantio de 4.000 mudas de árvores nativas na UC.

Em relação ao PEC, verificou-se também como medidas de compensação ambiental pela DERSA a instalação de oito passagens de fauna, nos pontos de maior fluxo de animais. Além disso, resgates e realocações de determinadas espécies de flora de importante valor biológico foram realizadas, em áreas de menor biodiversidade no PEC. Essas ações foram fruto de uma parceria entre a gestão do PEC, a Secretaria de Estado do Meio Ambiente, o Instituto de Botânica e a DERSA, e realizados estudos técnicos, levando em consideração a biologia das espécies. Como resultado, esse processo levou dois anos e foram resgatadas cerca de 40 mil plantas.

Em relação ao PEJ, além das ações externas previamente comentadas, vêm se desenvolvendo ações conjuntas da equipe com os responsáveis pelas rodovias, as quais consistem no mapeamento e monitoramento dos pontos mais frequentes de passagem de espécies de fauna. Segundo a gestão da UC, esses dados são geo-referenciados para que futuramente sejam planejadas passagens de fauna nos locais identificados. Além disso, em relação a Estrada Turística do Jaraguá, seus últimos $5 \mathrm{~km}$ encontram-se integralmente no interior da UC. Esta via é íngreme e sinuosa, utilizada pelos visitantes para acesso ao Pico do Jaraguá e é considerada uma via de fácil acesso para o interior da UC. Desse modo, a gestão alegou que existe um processo em análise pelo setor de Engenharia e Infraestrutura da $\mathrm{FF}^{49}$, visando transformá-la em Estrada Parque, em que a sua administração seria de responsabilidade da gestão do PEJ, e seria utilizada para fins ecoturísticos durante as atividades de uso público com os visitantes.

Por fim, os temas relacionados às infraestruturas lineares e seus impactos (e.g. atropelamento de fauna e incêndios) são discutidos e abordados em palestras e atividades de educação ambiental em todas às UCs, com exceção da EEcA. Segundo a sua gestão, as atividades de educação ambiental estão praticamente encerradas, por falta de funcionários e por causa dos riscos de febre maculosa (a UC está infestada por carrapatos transmissores da doença).

\footnotetext{
${ }^{49}$ Processo FF n ${ }^{\circ} 1453 / 2012$.
} 


\section{Poluição atmosférica}

Observa-se que a poluição atmosférica é considerada como um evento que já vem trazendo impactos prejudicias para as UCs que estão totalmente inseridas na malha urbana, tais como o PEJ e o PEC. Para as demais áreas, elas foram avaliadas como futuras ameaças para os próximos cinco anos. Logo, nota-se que essa pressão é proveniente da queima de combustíveis fósseis de veículos motorizados, instalações comerciais, industriais e atividades de mineração no entorno dos Parques.

Ressalta-se que cabe à CETESB a responsabilidade de monitorar, fiscalizar e licenciar as atividades potencialmente impactantes para os recursos naturais, bem como executar ações específicas de controle para a preservação e recuperação da qualidade ambiental, nos casos de irregularidades nos padrões de qualidade do ar definidos. Contudo, por parte das equipes de gestão de ambos os Parques, não foram verificadas atividades de monitoramento próprias ou uma efetiva cobrança nos períodos onde a qualidade ambiental encontra-se mais comprometida.

As ações realizadas pelas equipes de gestão dos Parques se resumem à promoção de discussões sobre o tema nos projetos de educação ambiental, desenvolvidos com os grupos visitantes e com as comunidades do entorno. Além disso, verificou-se no PEC o desenvolvimento de pesquisas científicas que envolvem essa temática, por pesquisadors do IF.

\section{Mudanças climáticas}

De maneira similar à poluição atmosférica, alguns impactos prejudiciais à integridade dos Parques do presente estudo são avaliados como provenientes das mudanças climáticas pelas suas equipes de gestão. Embora existam algumas controvérsias em relação ao tema, a preocupação com as mudanças climáticas vem crescendo fortemente ao longo dos últimos anos, onde diversos estudos desenvolvidos globalmente mostram evidências crescentes dos seus impactos para os ecossistemas. Dentre os estudos, destaca-se o produzido por Steffen et al. (2015), onde os autores mostram que o limite planetário (que define o espaço de operação segura para as atividades antrópicas) referente às mudanças climáticas encontra-se na zona de incerteza (risco em crescente ascensão). Desse modo, as emissões de altas concentrações de gases de dióxido de carbono, provenientes principalmente da queima de petróleo, gás e carvão têm vindo a subir globalmente.

De maneira geral, não foram verificadas ações de conservação diretas à mitigação dessa pressão nos Parques do presente estudo, nem ações preventivas nas Estações. Além disso, apesar de serem pressões severas aos Parques, não percebeu-se uma preocupação na adoção de medidas mais concretas para sua mitigação. Contudo, verificou-se no PEC o início do desenvolvimento de 
pesquisas científicas que permeiam a temática, tais como sobre absorção de carbono e degradação foliar.

\section{Espécies exóticas invasoras}

De acordo com Trzyna (2014), as espécies exóticas invasoras podem causar diversos prejuízos para as economias dos países, sendo uma das grandes ameaças globais à biodiversidade. A globalização acelera a sua introdução nos diferentes territórios, e sua propagação é facilitada por meio de portos marítimos, fluviais, aeroportos, ferrovias, caminhões, viveiros e jardins (TRYZNA, 2014).

Nesse sentido, observa-se gramíneas africanas em grande parte das UCs do presente estudo, espécies forrageiras altamente produtivas da agropecuária brasileira, e normalmente se estabelecem nas áreas de borda das UCs. Também verifica-se o frequente risco de propagação de espécies exóticas invaoras (muitas frutíferas, ornamentais e paisagísticas) presentes nas propriedades do entorno das UCs, que causam danos prejudiciais às UCs. Além disso, verifica-se a forte presença de cães e gatos domesticados em todas as UCs.

A recomendação para erradicação dessas espécies, quando fora de seu ambiente original, é mundialmente difundida, visto que a grande maioria dos estudos na área documentam apenas os seus efeitos negativos, e geralmente não comentam sobre os seus benefícios (BONANNO, 2016). Contudo, sabendo que as espécies exóticas invasoras, principalmente as espécies de flora terrestres (TRYZNA, 2014), são um problema em quase todas as áreas protegidas urbanas, considera-se no presente trabalho a recomendação de erradicação. Além disso, a ausência de conhecimento sobre as possíveis consequências e impactos de invasões de espécies exóticas não deve ser justificativa para a não adoção de medidas de controle (RESOLUÇÃO CONABIO, 2009).

O MMA, através da Resolução CONABIO n5, de 21/10/2009, reconhecendo a importância do problema para o o país, recomenda uma série de ações ${ }^{50}$ relacionadas à prevenção de novas introduções, detecção precoce, erradicação, manejo (controle mecânico, químico, biológico) e monitoramento das espécies exóticas invasoras, que possam trazer impactos prejudiciais aos ecossistemas brasileiros.

Em relação as espécies exóticas de fauna (cães, gatos etc.), não é permitida a sua entrada e permanência nas UCs de proteção integral, com exceção para os casos previstos na Lei Federal

\footnotetext{
${ }^{50}$ Essas ações devem ser executadas de acordo com regulamentos nacionais e códigos internacionais existentes.
} 
n'11.126, de 27/06/2005 e suas atualizações (cães-guia), e para as ações de manejo ou pesquisa, devidamente justificadas e autorizadas pela administração da UC.

Das ações de conservação identificadas nos quatro casos de estudos, observa-se que todas elas vêm realizando as etapas de detecção (identificação e mapeamento das espécies conforme a sua localização na UC) e monitoramento das espécies exóticas invasoras que ocorrem em seus territórios. Além disso, com exceção do PEJ, verificam-se a adoção de ações de erradicação e manejo, com recursos de compensação ambiental de empreendimentos potencialmente impactantes. Para as ações de manejo não verificou-se uma frequencia para a sua realização por parte das equipes de gestão, sendo mais comumente realizado em situações críticas.

Além dessas ações, observa-se que apenas no PEC, é feita a orientação e sensibilização de proprietários nas áreas limítrofes à UC, através de rondas periódicas da equipe de funcionários do Parque, buscando-se abordar através de um diálogo com os moradores sobre os impactos do uso de espécies exóticas invasoras em suas residencias, a fim de impedir as introduções intencionais e não-intencionais. Segundo a gestão, a sensibilização pública é fundamental para se obter um êxito no controle dessas espécies, mesmo reconhecendo a imprevisibilidade das ações dos moradores.

Por fim, em relação aos animais domésticos que invadem as UCs, observa-se que não existe um programa oficial para o controle desses animais, em todas as UCs do presente estudo, nem campanhas de conscientização. Na EEcA, foram realizadas reuniões com o poder público e a comunidade sobre o possível abate desses animais, o que gerou bastante polêmica e não foi permitido. Em relação ao PEC, apesar de não haver um programa oficial para o controle desses animais, a gestão busca encaminhá-los para o Centro de Zoonoses de São Paulo, onde é realizada a castração e posterior doação.

\section{Incêndios}

As UCs brasileiras vêm sofrendo anualmente com a ocorrência de incêndios florestais (IBAMA, 2002), sendo o combate e prevenção desses eventos um dos grandes desafios para as equipes de gestão dessas áreas (BONTEMPO et al., 2011). As principais causas dos incêndios em UCs se deve pelo uso inapropriado do fogo, seja para limpeza de pastagens e áreas de cultivo (MEDEIROS, 2002), celebrações (soltura de balões e fogos de artifícios), desmatamento ilegal, práticas religiosas (uso de materiais inflamáveis) e queima de lixo (SOARES; BATISTA, 2007), podendo destruir amostras representativas de ambientes nativos (BONTEMPO et al., 2011) e prejuízos para a biodiversidade, ciclos hidrológicos e do carbono na atmosfera (SILVA, 2001). 
Nesse contexto, os incêndios florestais foram avaliados como pressões para os quatro casos de estudo, variando em grau de intensidade, sendo pressões mais severas ao PEC e à EERP. Logo, para diminuir os focos de incêndio do Estado de São Paulo e proteger os recursos naturais existentes, o Governo de São Paulo institui o Sistema Estadual de Prevenção e Combate a Incêndios Florestais no Estado de São Paulo, através da Operação Corta Fogo. Segundo o Sistema, devem ser impregadas ações de prevenção, monitoramento, controle e combate a incêndios florestais, coordenadas em conjunto pela Secretaria de Meio Ambiente, Casa Militar- Defesa Civil, Corpo de Bombeiros, Policia Militar Ambiental e Municípios.

Verifica-se que todas as UCs do presente estudo participam da Operação Corta Fogo, na qual cada UC possui um plano preventivo emergencial de combate aos incêndios, são feitas capacitações periódicas com os funcionários, aquisição de equipamentos de combate (com exceção da EEcA, que não possui recursos próprios e utiliza a brigada de combate a incêndios da Floresta Estadual de Assis) e são estabelecidas parcerias de apoio com instituições públicas e privadas. Para os casos de constatação de incêndios criminosos, as equipes de gestão buscam acionar a Polícia Militar (PM), que é responsável pela resolução dos casos.

Também verifica-se ações de fiscalização e monitoramento em todas as UCs, através do programa SIM em conjunto com a Coordenadoria de Fiscalização Ambiental da SMA e Policiamento Ambiental, onde são realizadas rondas diárias. De maneira geral, observa-se a realização de rondas internas e externas (nas áreas limítrofes às UCs) durante o período diurno e vespertino (geralmente das 7 horas às 17 ou 19 horas), ao passo que a segurança interna das UCs ocorre 24 horas. Desse modo, ressalta-se que para todos os casos de estudo, a fiscalização foi avaliada como deficiente pelos gestores. Isso se deve pelo baixo número de vigilantes no período do dia, e ainda menor durante o período noturno, onde a vigilância fica restrita às edificações principais da área.

Além dessas ações, na área de influencia das UCs, verifica-se que existe um programa de manutenção das margens das rodovias pelo DER, o que, segundo a gestão, vem auxiliando a diminuir os focos de incêndios nos últimos anos.

Em relação as ações de sensibilização da população dos entornos da UC, observa algumas iniciativas, tais como no PEJ e no PEC, onde realizam abordagens com os proprietários de chácaras do entorno para orientação e sensibilização sobre os impactos do uso indevido do fogo, principalmente nas áreas mais periféricas, onde se observa com frequência limpezas de terrenos e 
soltura de balões. Verifica-se também que a EERP busca sensibilizar os grupos visitantes através de atividades de educação ambiental. Além disso, em relação ao PEC, constatou-se a iniciativa da gestão em mobilizar agentes essenciais para o combate dos incêndios (e.g. membros da Defesa Civil, PM e Corpo de Bombeiros) para participarem como membros do Conselho Consultivo do Parque, visto que o chefe da UC faz parte da equipe Operação Corta Fogo.

Por fim, devido ao grave incêndio ocorrido na EERP em 2014, o qual atingiu uma área de aproximadamente 70 hectares, verificou-se a contratação de vigilantes noturnos e a criação de um plano de recuperação da flora (e.g. reflorestamento de espécies nativas) e fauna (e.g. programa de alimentação da fauna atingida). Contudo, desde o incidente, o plano de recuperação da flora ainda está em análise pelo órgão gestor.

\section{Ocupações ilegais}

Verifica-se que as ocupações ilegais ocorrem no entorno das UCs do presente trabalho (com exceção da EERP), sendo mais expressiva nas UCs totalmente inseridas na malha urbana (PEJ e PEC). Além disso, elas vêm sofrendo constantes pressões para flexibilizar a sua ZA, alterando para categorias menos restritivas. Caso isso venha a ocorrer, será permitido usos residenciais e não residenciais, resultando em novos assentamentos e na expansão dos existentes, expondo-as a uma situação de maior vulnerabilidade. Logo, controlar a urbanização e a ocupação do entorno das UCs é fundamental, visto o cenário esperado para as próximas décadas.

Segundo Guimarães e Pellin (2015), ações de conservação para as UCs urbanas devem ser planejadas e implementadas em conjunto com os demais atores que compõem o território (órgãos públicos, autarquias, fundações, sociedade civil, entre outros), de maneira que contemple de maneira interdisciplinar as diversas políticas públicas dos municípios, tais como nas áreas de habitação, mobilidade urbana, educação, entre outras. Além disso, as autoras ressaltam que essas ações devem estar embasadas em aspectos legais, econômicos, sociais e ambientais, presentes em cada realidade.

De maneira geral, basicamente todas as UCs buscam fiscalizar e monitorar diariamente seus territórios e áreas limítrofes às UCs. Conforme mencionado anteriormente, apesar da fiscalização ocorrer 24 horas por dia, existem limitações, devido ao baixo número de funcionários. Além disso, os limites das UCs (com exceção do PEC) são bem delimitados, com a presença de cercamento e sinalização (placas informativas). 
Em relação ao PEC, as ocupações ilegais aumentaram drasticamente, e ocorrem principalmente nos municípios de São Paulo e Guarulhos. Nesse sentido, conforme mencionado anteriormente, apenas 50 a $69 \%$ da UC encontra-se regularizada, bem como existe uma imprecisão dos seus limites (uma distorção no georreferenciamento de aproximadamente 80 metros), favorecendo as ocupações ilegais.

Desse modo, caso haja uma ocupação ilegal em estágio inicial (que não esteja consolidada, isto é, uma área não coberta), a gestão orienta os indivíduos envolvidos sobre a irregularidade e realiza o desmonte do local. Porém, caso a ocupação esteja consolidadada (com pessoas residindo na área), a equipe necessita comunicar os órgãos municipais responsáveis, entrando com uma ação judicial na Procuradoria do Estado para o processo de realocação dessas pessoas. Desse modo, cabe aos órgãos municipais responsáveis a reitegração de posse das ocupações irregulares do entorno do PEC.

Contudo, nos últimos cinco anos, não foram observadas nenhuma ação municipal para reitegração de posse dessas ocupações. Além disso, através de trabalhos de vereadores, essas áreas vão sendo urbanizadas e consolidadas, tais como com a ligação de água e energia. A partir disso, dificulta-se o processo de retirada dessa população, além de que, costumam levar anos para serem concluidos, o que induz o estabelecimento de novas ocupações informais, bem como os valores de indenização não são sempre suficientes para a aquisição de novas moradias, resultando na permanência dos assentamentos.

Nesse contexto, além das ações de proteção, verificam-se também atividades de educação ambiental promovidas pelo Núcleo de Educação Ambiental do PEC, onde é realizado o mapeamento prévio das comunidades do entorno, e a abordagem com os moradores. Durante o contato, busca-se um diálogo de aproximação com esses moradores, com objetivos de trazê-los para dentro do Parque e informar sobre a importância da UC para a região, abordando diversas questões, tais como sobre o impacto de suas ações na área.

Em relação à EEcA, de maneira similar ao PEC, para os casos de parcelamento ilegal do solo por chácaras e condomínios na ZA, os proprietários de áreas ilegais são notificados pela equipe de gestão, onde a administração passa o problema para a Procuradoria Geral do Estado (PGE), a qual aciona o Ministério Público para resolver a questão. No entanto, dada a magnitude do conflito, muitos casos ainda encontram-se sem resolução. Paralelamente, a gestão da Estação elaborou um folder durante as reuniões do Conselho, o qual foi distribuído para todos os moradores e 
proprietários da vizinhança, explicando o que é uma ZA, os seus usos e restrições, com o objetivo de sensibilizar esses proprietários que vêm causando conflitos. Além disso, há dois anos atrás houve a invasão de um grupo de assentados do MST na Floresta Estadual de Assis, próximo da divisa com a EEcA, onde o Ministério Público foi acionado para a retirada dessas pessoas, conflito que já resolvido.

No caso do PEJ, além das ações de fiscalização e monitoramento comentadas, verifica-se também que a gestão busca dialogar com a comunidade, na tentativa de sensibilizar e conscientizálos sobre os impactos de suas ações que atingem o Parque. O diálogo é realizado com frequência nas reuniões do Conselho, onde as demandas e problemas do parque são discutidos e compartilhados. Segundo o gestor, a comunicação entre esses atores tem se mostrado efetiva, visto o aumento da participação dos moradores do entorno nas reuniões.

\section{Crimes}

De acordo com Souza e Lima (2007), verifica-se que os índices de violência social no país vêm aumentando como nunca ocorrido antes na história. Além disso, embora seja mais intensa nas áreas urbanas, observa-se um processo de interiorização da violência (SOUZA; LIMA, 2006), resultando em graves problemas de segurança pública para grande parte do país.

Nesse sentido, segundo Tryzna (2014), pelo fato das áreas protegidas urbanas estarem totalmente inseridas ou próximas às cidades, sendo, portanto, de fácil acesso, geram oportunidades para a ocorrência de crimes. Desse modo, essa situação foi observada para todas às UCs, variando em grau de intensidade.

Das ações observadas pelas equipes de gestão, verifica-se em suma a adoção de ações de proteção, isto é, fiscalização através de rondas diárias por vigilância terceirizada, a qual mostra-se insuficiente pelo número reduzido de funcionários. Além disso, em todos os casos, verifica-se articulações com os batalhões da PM próximos e cobertura da Guarda Civil Metropolitana, os quais são acionados para os casos de crimes mais graves. Segundo os gestores, a presença deles contribuem para o aumento da segurança na área. Além disso, observa-se no PEC o treinamento frequente de policiais dentro do Parque, o que, segundo a gestão, auxilia na inibição de possíveis crimes. Por fim, no caso do PEJ, foi observada a intenção de realização de um convênio com uma escola da PM próxima ao Parque, para que eles cumpram suas horas de estágio no parque. 


\section{Disposição irregular de resíduos}

Segundo Trzyna (2014), os resíduos são um problema recorrente nas áreas protegidas urbanas, prejudicando a vida de animais selvagens, e podendo permanecer nos ecossistemas por longos períodos. Logo, observa-se que a disposição irregular de resíduos é uma pressão e ameaça para todas as UCs do presente estudo, variando em grau de intensidade de alto para severo.

De maneira geral, todos os resíduos produzidos nas UCs são acondicionados em lixeiras, dispostas estratégicamente em diferentes áreas. Existe uma equipe de manutenção terceirizada que é direcionada para a limpeza das UCs. O sistema de coleta é realizado pelo serviço público da prefeitura, e observa-se que somente no PEJ os resíduos recicláveis são destinados ao sistema de coleta seletiva. Além disso, para todas as regiões do entorno das UCs, existe a fiscalização diária, e quando é verificado o descarte irregular, a prefeitura é acionada para realizar a limpeza da área.

Em relação aos Parques, verifica-se a existência de lixeiras com aberturas menores (para se evitar a retirada por parte dos animais) e sinalização nas áreas de uso público. Também observa-se que nas trilhas não existem lixeiras, evitando a possível contaminação da fauna silvestre. Além disso, especificamente no PEC, os resíduos orgânicos provenientes de material de poda são utilizados como adubos no próprio Parque.

$\mathrm{Na}$ EEcA, verifica-se a presença de um aterro sanitário localizado próximo ao limite da UC, o qual ainda não foi encerrado pela Prefeitura do Município, segundo as exigências da CETESB e Ministério Público. Desse modo, o Conselho Consultivo da UC vem realizando negociações com todos os envolvidos na tomada de decisão. Porém, as ações prometidas ainda não foram concretizadas e o problema se extende.

A questão do lixo é um tema muito trabalhado nos projetos de educação ambiental nas UCs do presente estudo, com exceção da EEcA, onde não foi verificado um programa de educação ambiental. Em relação ao PEJ e para a EERP, os projetos são realizados para os grupos visitantes, não havendo uma abordagem para a comunidade residente do entorno (apesar de muitos visitantes do PEJ residirem no seu entorno). Já para o PEC, verifica-se um ostensivo trabalho de sensibilização e conscientização executados pelos monitores ambientais, destacando-se as iniciativas de realização de palestras nas escolas da região e de multirões de limpeza (recolhimento dos resíduos com a participação da comunidade, realizado uma vez por mês). 


\section{Caça ilegal}

Segundo Mace e Reynolds (2001), a exploração de animais é uma das principais causas pelas quais as espécies vêm sendo ameaçadas. Especificamente em relação às florestas tropicais, sugere-se que a caça para subsistência é uma das principais ameaças para as espécies silvestres nativas (REDFORD, 1992), sendo portanto necessário identificar as regiões onde essa atividade ocorre em maior intensidade, bem como determinar intervenções adequadas para mitigar esse problema (ROWCLIFFE et al., 2003).

No país, as atividades de caça de animais silvestres são proibidas legalmente, segundo a Lei $\mathrm{n}^{\mathrm{o}}$ 5.197, de 03/01/1967. Contudo, verifica-se a ocorrência dessa atividade ilegal nas UCs do presente estudo, com exceção da EERP. Como fato em comum à essas UCs, verifica-se que a caça ocorre geralmente para subsistência e está relacionada a questões culturais. Além disso, a ação de caçadores ocorre geralmente nos períodos onde a fiscalização é mais deficiente, durante a noite e madrugada, bem como a entrada é facilitada pelas vias de acesso próximas.

De maneira geral, para se evitar que essa prática ocorra, observa-se que todas as UCs realizam operações de fiscalização diárias. Nos casos de flagrantes, as equipes de gestão adotam uma postura de repreensão, acionando a PM para o encaminhamento das devidas sanções. Também observa-se a presença de sinalização no interior e entorno dessas UCs, ressaltando a proibição dessa atividade.

Para o caso dos Parques, verifica-se a adoção de ações de sensibilização, promovidas nas atividades de educação ambiental com os visitantes, auxiliando de maneira coadjuvante no combate à caça ilegal. Além disso, o PEC busca discutir sobre essa temática, durante as atividades de educação ambiental com a comunidade do entorno, fora da UC. Especificamente para o PEJ, são feitas operações noturnas em casos esporádicos.

\section{Poluição hídrica}

A poluição dos recursos hídricos ocorre nas UCs do presente estudo, com exceção da EEcA. Para os casos das UCs totalmente inseridas na malha urbana, as principais causas da poluição se deve principalmente pelo lançamento clandestino de efluentes domésticos, provenientes das comunidades do entorno (caracterizadas pela baixa renda e alta vulnerabilidade social e econômica), bem como pelo escoamento de resíduos das rodovias do entorno. Já para a EERP, a poluição se deve pelas atividades agropecuárias, implicando em prejuízos a qualidade das águas que cortam a EERP e de seu entorno. 
De maneira geral, para os casos de irregularidades no entorno, a CETESB, Agência do Governo do Estado responsável pela fiscalização e monitoramento das atividades que potencialmente possam vir a degradar os recursos naturais, no caso, a água, é acionada. Além disso, verifica-se que os sistemas de tratamento de esgoto das UCs foram regularizados e encontram-se em situação adequada, garantindo a proteção dos recursos hídricos da UC.

Especificamente em relação ao PEJ, existe um projeto de engenharia que se encontra em fase de análise pelo órgão gestor, a fim de conter a emissão desses efluentes, revitalizar os seus corpos d'água e desassorear os sedimentos do lago dentro da UC. Ademais, para os Parques do presente estudo, observa-se a existência de monitoramento e fiscalização das áreas de entorno.

Apesar das ações de proteção, a poluição hídrica nas UCs urbanas tende a piorar com a expansão de mais ocupações ilegais. Logo, não foram observadas articulações com os órgãos e instituições responsáveis pela gestão dos recursos hídricos dos municípios do entorno, para a recuperação dos corpos hídricos que encontram-se mais vulneráveis.

\section{Extração de produtos não-madeireiros}

Verifica-se como pressão comum aos Parques do presente estudo, a coleta de recursos não madeireiros, tais como plantas medicinais e ornamentais (e.g. orquídeas e bromélias), por parte de visitantes e moradores do entorno, nas áreas de uso público e áreas limítrofes às UCs.

Das iniciativas observadas em ambos os Parques, existem rondas diárias de fiscalização, no interior e entorno das UCs. Além disso, a equipe de funcionários busca recepcionar os visitantes, mostrando as regras do parque. Para os casos de flagrantes, os funcionários orientam e notificam os indivíduos, explicando que se trata de uma UC de proteção integral (uso indireto), bem como sobre a importância da preservação dessas espécies para a área. Também há diferentes tipos de sinalização (placas informativas, folders, banners) e o tema é abordado nos projetos de educação ambiental desenvolvidos com a comunidade. Contudo, trata-se de uma pressão de difícil controle, principalmente nas áreas limítrofes das UCs, onde se localizam as ocupações urbanas, dada a imprevisibilidade das ações dos moradores.

\section{Atividades religiosas}

A prática de atividades religiosas é comum nas UCs do presente estudo, exceto para a EEcA. Essas atividades ocorrem geralmente aos finais de semana, e durante os períodos onde a fiscalização é menor. 
De maneira geral, as UCs buscam adotar ações de proteção, através da fiscalização diária, nas áreas onde sabe-se que essa prática ocorre, especialmente em época de estiagem. Em relação ao PEJ, onde essa pressão é mais intensa, a gestão da UC também realiza a capacitação da equipe para agir nessas situações, bem como são feitas operações noturnas esporadicamente. No caso da EERP, verifica-se a divulgaçào dos riscos dessa prática para os grupos visitantes durante as atividades de educação ambiental e mídia de maneira geral.

\section{Disputas sobre o uso d'água}

As disputas sobre o uso d'água ocorrem notadamente nas UCs inseridas na RMSP, visto a precária distribuição de água da rede pública do entorno do Parque. Para o caso do PEC, Durante a rotina diária de fiscalização, as barragens são identificadas e apreendidas pelos funcionários, onde se realiza um laudo de dano ambiental. Segundo o gestor, geralmente é difícil encontrar os responsáveis em flagrante, e quando isso ocorre, existe a negação imediata do ato. Contudo, a equipe do PEC sempre busca realizar um trabalho de conscientização muito cuidadoso com esses moradores, pois a presença do agente fiscalizador inevitavelmente não é bem aceita.

No caso do PEJ, a equipe do parque identificou e mapeou todos os barramentos clandestinos encontrados, e estes estão sendo monitorados. Os proprietários já foram notificados, onde foi dado um prazo para a retirada dos barramentos, bem como foram sensibilizados sobre os impactos provenientes dessa atividade ilegal.

De maneira geral, dada a fragilidade do sistema e por se tratar de uma questão de sobrevivência das comunidades do entorno, essas atividades acabam se tornando inevitáveis, onde infelizmente esses moradores são vítimas e comumente podem não ter outra opção.

\section{Conflitos entre humanos e animais selvagens}

De acordo com Trzyna (2014), a probabilidade de ocorrer conflitos entre humanos e animais selvagens aumentam nas áreas protegidas urbanas, visto que muitas dessas abrigam significativas populações de fauna silvestre, e estão inseridas ou próximas a centros populacionais. Logo, a aproximação das cidades em direção às essas áreas pode gerar conflitos indesejáveis e a a sua prevenção ou mitigação deve ser uma questão de grande importância para os gestores desses locais (TRZYNA, 2014).

No presente trabalho, observa-se que os conflitos entre humanos e animais selvagens são verificados em todas as UCs, variando em grau de intensidade. Dentre os conflitos, destacam-se 
como os mais comuns os casos de atropelamentos da fauna silvestre, nas vias de acesso próximas, bem como o oferecimento de alimentos para esses animais.

As ações observadas para conter os casos de atropelamentos foram mencionadas no item "estradas, rodovias e ferrovias". Para os demais conflitos, verifica-se que as equipes de gestão dos Parques e da EERP buscam realizar um trabalho de conscientização e educação ambiental com os grupos visitantes, alertando sobre os riscos de acidentes e possíveis conflitos com a fauna silvestre, acidentes e doenças oriundas do contato entre estes e humanos. Ademais, o PEC também busca sensibilizar os moradores do entorno do Parque, durante as atividades de educação ambiental promovidas fora da UC, pelo "Projeto Cuca: Conhecer para Preservar".

Em relação aos Parques, onde permite-se a visitação, observa-se que as equipes de gestão procuram recepcionar os visitantes, mostrando as regras do parque, e dentre elas, destacam a proibição de oferta de alimentos para os animais. A fiscalização também funciona como um instrumento de controle, onde os infratores são notificados e orientados, procurando sempre sensibilizá-los e conscientizá-los para que não ocorra novamente. Ademais, possuem placas informativas, folders e banners, além do tema ser abordado nas atividades de educação ambiental.

Para a EEcA, onde verifica-se casos de animais silvestres predando animais domésticos ou de criação (e.g. gado, ovelhas) das propriedades vizinhas à UC, gerando potencial de conflito, ações de fiscalização foram relatadas como a principal ação visando a mitigação desse problema. Além disso, verifica-se que não existe suporte do Estado para com os proprietários que são prejudicados em caso de acidentes com a fauna silvestre.

\section{Linhas de transmissão de energia (LTS)}

O fornecimento de energia elétrica é considerado como um dos elementos que asseguram o bem-estar social das populações, fortemente presente em áreas urbanas. Logo, as redes de transmissão de energia elétrica são consideradas infraestruturas lineares, e quando instaladas podem trazer impactos, principalmente quando localizadas no interior ou próximas de UCs.

De acordo com Oliveira e Zaú (1998), para a instalação dessas redes, verifica-se diversos impactos, tais como à indução de cargas elétricas sobre pressoas ou objetos situados nas imediações das faixas de servidão, alteração na drenagem natural, supressão de vegetação, compactação do solo, erosão, assoreamento dos cursos de água, fragmentação de habitats, impacto na paisagem visual, entre outros. Além disso, essas linhas precisam de manutenção periódica, e para tanto, é 
necessária a abertura de acessos, os quais podem ser vias indutoras de processos de urbanização e de atividades ilegais (e.g. caça, coleta de espécies nativas).

No país, para a instalação de LTs de significativo impacto ambiental, é necessário a realização de EIAs, onde “(...) o empreendedor é obrigado a apoiar a implantação e manutenção de unidade de conservação do Grupo de Proteção Integral, de acordo com o disposto neste artigo e no regulamento desta Lei" (BRASIL, 2000, Art. 36º). Nesse contexto, observa-se que as LTs são pressões para as UCs do presente estudo, com exceção da EERP.

Para o caso do PEC, a equipe do Parque solicita ostensivamente aos responsáveis pelas LTs a realização de manutenções periódicas nos locais de interferência das linhas, como medidas preventivas contra acidentes. Essa estratégia é considerada positiva, pois não houve ocorrência de nenhum tipo de acidente nos últimos cinco anos. Além disso, a gestão da UC observou uma oportunidade em desenvolver um projeto de educação ambiental ("Projeto Cuca: Conhecer para Preservar") com a comunidade do entorno (nas residências, condomínios e escolas), como condicionante à licença de operação das LTs. Atualmente o projeto é promovido pela CTEEP, através de parcerias com associações de bairro e diferentes atores da sociedade civil, e executado por uma equipe de monitores terceirizados. O objetivo do projeto é implementar ações de educação socioambiental e de conscientização sobre a importância da preservação do Parque, bem como sobre a convivência segura com as estruturas de transmissão de energia e faixas de segurança.

Além dessas ações, observa-se que a equipe de gestão do Parque é ciente dos impactos ocasionados devido ao campo magnético gerado, e possui a intenção de incentivar a realização de pesquisas científicas sobre os impactos resultantes do campo magnético gerado pelas LTs, e de que forma ele afeta a fauna e a flora da UC.

Em relação à EEcA, observa-se uma forte pressão para a instalação de LTs na ZA da UC nos últimos anos. Segundo a gestão, vêm sendo conduzidas articulações com as empresas de energia, e assim tem sido possível negociar a transferência da localização de determinadas linhas para locais mais adequados, fora da ZA da UC. Além disso, se por um lado os licenciamentos ambientais significam prejuízos ambientais à UC e seu entorno, por outro eles propiciam a execução de serviços e a aquisição de equipamentos. Como por exemplo, algumas obras relacionadas com a ampliação do fornecimento de energia elétrica resultaram no aporte de recursos para a UC como compensação ambiental (e.g. aquisição de recursos para levantamentos de vegetação, fauna e solos do Plano de Manejo e restauração de mata ciliar de propriedades vizinhas 
a EEcA, na ZA). Por fim, não foram relatadas ações de conservação para a mitigação dessa pressão para o PEJ.

\section{Turismo e recreação}

Segundo Balmford et al. (2009), verifica-se uma tendência no aumento de atividades de recreação e turismo em áreas protegidas. Além disso, com o aumento do desenvolvimento urbano, as áreas protegidas funcionam como meios primários para que a população venha a ter experiências em ambientes naturais (TRZYNA, 2014). Contudo, a crescente visitação pode gerar preocupações em relação a degradação dos recursos da área natural, podendo ser potenciais pressões e ameaças para as áreas protegidas, principalmente as urbanas. Desse modo, dos casos de estudo da presente pesquisa, apenas nos Parques existe a possibilidade de desenvolver atividades de recreação em contato com a natureza, e turismo ecológico (BRASIL, 2000, Art.11º). Assim, dentre os Parques, verifica-se que as atividades de turismo e recreação são avaliadas como pressões apenas no PEC.

Apesar do PEJ receber uma estimativa de até 10 mil visitantes por final de semana, a gestão da UC não avaliou as atividades de recreação e turismo como uma pressão ou ameaça. Segundo a gestão da UC, realiza-se no Parque atividades de turismo de aventura e ecoturismo, de maneira ordenada e sem impactos. Em suma, o uso recreativo é controlado na zona de uso público, onde é realizado o ordenamento no número de pessoas que acessam as trilhas e o controle de veículos. Nesse contexto, alguns autores (LI; HAN, 2001; ERVIN, 2003; NCHOR; UGOGO, 2012; FONTOURA; MEDEIROS; ADAMS, 2015) também demonstram que as atividades de recreação e turismo não foram consideradas pressões e ameaças para algumas UCs, ou variaram de leves à moderadas. Segundo Fontoura, Medeiros e Adams (2015), isso pode ser explicado pela existência de infraestrutura, aporte de recursos financeiros e investimentos, bem como a execução de gerenciamento de uso público nessas UCs.

Em relação ao PEC, verifica-se um controle do número de ingressos vendidos, tanto para prestação de contas por parte financeira quanto por estimativas de visitação e perfil de público. Além disso, os monitores ambientais realizam o trabalho de abordagem e recepção dos visitantes, além de projetos de educação ambiental desenvolvidos dentro da UC e com o público do entorno. Durante essas atividades, busca-se promover um diálogo entre os atores, demonstrando a diferenciação entre uma UC e um parque urbano, discutindo sobre a importância da área, bem como sobre os usos legais e ilegais no seu interior. 
Para as ações de ecoturismo, o PEC participa do Projeto Trilhas de São Paulo, o qual faz parte do Projeto Ambiental Estratégico de Ecoturismo, da SMA. Além de promover as atividades de ecoturismo, o Projeto também busca a divulgação das UCs do Estado de São Paulo. No momento em que o participante se inscreve no Projeto, ele ganha um Passaporte onde encontra todas as informações sobre as trilhas que participam do programa, além de orientações, agendamentos, mapas, atrativos e estruturas da área. A cada trilha finalizada, o visitante é contemplado com brindes do Programa, estimulando-o a continuar a atividade.

Para fins de proteção do patrimônio histórico-cultural do PEC e dos demais atrativos, foi delimitado uma faixa de 50 metros para cada lado destes, compondo o sistema de zoneamento do PEC. Já os estacionamentos, centros de visitantes, áreas de piquenique e demais infraestruturas de uso público foram sinalizados e estão localizados na Zona de Uso Intensivo, próximas às sedes administrativas de cada núcleo.

Em relação ao baixo aproveitamento do potencial turístico e serviços oferecidos aos visitantes, recentemente o projeto de lei $n^{\circ}$ 249/2013 foi aprovado, e permite a concessão a exploração dos serviços e/ou uso de áreas inerentes ao ecoturismo para determinadas unidades da categoria Parque do SNUC, dentre as quais o PEC. Através das pesquisas bienais realizadas com os visitantes, foi verificado uma alta demanda por atividades relacionadas ao ecoturismo na região, bem como por demais serviços. Segundo a opinião do gestor, além da equipe de funcionários e do órgão gestor não possuírem expertise para tocar tais atividades e oferecer esses serviços, essa demanda carece de altos investimentos e recursos orçamentários, do qual o Estado não dispõe. As ações mínimas de responsabilidade da gestão do PEC já são comprometidas pelo insuficiente número de funcionários, pelo orçamento limitado, bem como pela burocratização dos processos que competem ao órgão gestor. Logo, o processo de concessão é visto como algo positivo pela equipe. Contudo, ressalta-se que este deverá primeiramente respeitar as diretrizes propostas no SNUC, cabendo à gestão do PEC a fiscalização de tais atividades. Desse modo, a equipe vem trabalhando em um plano de negócios, onde estão sendo identificadas as áreas pertinentes a tais serviços e atividades, baseado no conhecimento e experiência de trabalho na área e no plano de manejo. 


\section{Poluição sonora}

A poluição sonora ocorre quando sons indesejados (e.g. tráfego de veículos, buzinas, sobrevôo de aviões) afetam prejudicialmente processos naturais importantes para a sobrevivências das espécies (e.g. alimentação, reprodução, proteção) (TRZYNA, 2014).

Para os casos de estudo do presente trabalho, observa-se que todas as UCs alegaram estar sofrendo algum impacto proveniente dessa pressão, sendo mais intensa para os Parques, os quais estão inseridos totalmente na malha urbana e recebem um alto número de visitantes. Apesar de ser uma pressão que afeta todas as UCs, observa-se que existem ações para mitigar essa pressão apenas nos Parques. De maneira geral, das ações de conservação adotadas, as equipes de gestão buscam orientar e conscientizar os visitantes sobre os impactos resultantes da produção de ruídos e suas implicações para a fauna. Caso haja atos em flagrantes (e.g. visitantes com aparelhos de som), os funcionários são orientados a adotar uma abordagem de diálogo, explicando sobre a proibição dessa atividade. Ademais, existem diferentes tipos de sinalização (placas informativas, folders, banners) e o tema é abordado nas atividades de educação ambiental.

Contudo, ressalta-se que a grande parte das fontes de ruídos são externas para essas UCs, e apesar de haver legislações federais, estaduais e municipais para controle de ruído, é frequente os usos indevidos no entorno das UCs, não havendo uma fiscalização efetiva por parte dos órgãos municipais. Também não foi verificado uma cobrança das equipes de gestão para o aumento do controle dos ruídos nos entornos.

\section{Poluição visual}

Similarmente à poluição sonora, as áreas protegidas urbanas também são impactadas pela poluição visual das áreas urbanas, proveniente de luzes artificiais noturnas, as quais podem interferir negativamente nos organismos e funções ecossistêmicas (TRZYNA, 2014). Para os casos de estudo da presente pesquisa, verifica-se que a poluição visual já traz impactos para o PEJ, PEC e EEcA, variando em grau de intensidade. Um dos motivos que contribuem para a não ocorrência dessa pressão na EERP é não haver iluminação pública na rodovia adjacente à UC.

Para os demais casos, não foram relatadas ações de conservação diretas e iniciativas para a mitigação dessa pressão. No entanto, por se tratar de uma pressão externa às UCs, cabe aos municípios abrangentes que determinem o uso discreto da iluminação artificial, bem como tipos de iluminação mais energéticas e menos agressivas ao meio ambiente. Contudo, não foram verificadas 
legislações e regulamentos específicos por parte desses municípios, e nem uma cobrança mais efetiva por parte das equipes de gestão das UCs.

\section{Atividades industriais}

$\mathrm{O}$ aumento da demanda para a instalação de indústrias de diversas naturezas próximas às áreas protegidas é crescente, e podem afetar a saúde dos ecossistemas e espécies (WORBOYS, 2015). Desse modo, observa-se impactos prejudicia provenientes das atividades industriais próximas ao PEJ, avaliada como uma pressão moderada. Além disso, ressalta-se que apesar de não haver novas instalações na região nos últimos cinco anos, a Lei Complementar Municipal $n^{\circ}$ 123/2004 do município de Osasco confere uma série de incentivos fiscais para novas instalações de empresas e industrias na região, sendo alta a probabilidade dessa pressão aumentar nos próximos anos. Das ações de conservação observadas, a equipe do PEJ fiscaliza a monitora as áreas limítrofes a Zona Exclusivamente Indutrial, além de realizar palestras periódicas com as indústrias e empresas na ZA da UC.

\section{Mineração}

As atividades de mineração consistem na extração de recursos minerais dos solos, e são consideradas ameaças para diversas áreas protegidas (MASCIA; PAILLER, 2011; DURÁN; RAUCH; GASTON, 2013), trazendo impactos ambientais diversos, tais como supressão de vegetação, poluição hídrica, atmosférica, sonora, contaminação dos solos, erosão, perda da biodiversidade, entre outros (DURÁN; RAUCH; GASTON, 2013). Além disso, já se sabe que as áreas protegidas que possuem atividades de mineração dentro de seu território correspondem à $6 \%$ da cobertura total do sistema de áreas protegidas terrestres, ao passo que aquelas com atividades de mineração com ou até $10 \mathrm{~km}$ de suas fronteiras, correspondem a cerca de $14 \%$ da área total (DURÁN; RAUCH; GASTON, 2013).

Em relação às UCs do presente estudo, verifica-se a ocorrência dessas atividades no entorno do PEC, trazendo impactos prejudiciais à UC. De acordo a gestão, a equipe do Parque realiza a fiscalização e o monitoramento constante dessas atividades, e quando é verificado alguma irregularidade, um documento técnico é encaminhado para a CETESB e ela como órgão licenciador é responsável por notificar as pedreiras e realizarem o trabalho de recuperação dos danos adequado. Apesar do alto impacto para a UC, as atividades de mineração são localizadas e não há indícios de 
novas instalações nos próximos anos. Além disso, a fiscalização ostensiva tem sido eficiente e devido esses fatos, tal atividade representa uma ameaça moderada para o PEC.

\section{Discussão}

O quadro 8 ilustra as principais características e observações verificadas para os quatro casos de estudos nacionais e embasa a discussão do presente capítulo. 
Quadro 8. Quadro síntese das principais características e observações referentes aos casos de estudos nacionais.

\begin{tabular}{|c|c|c|c|c|c|c|}
\hline \multirow{2}{*}{\multicolumn{2}{|c|}{ CARACTERÍSTICAS }} & \multicolumn{4}{|c|}{ UCS URBANAS DO ESTADO DE SÃO PAULO } & \multirow{2}{*}{ OBSERVAÇÕES } \\
\hline & & PEJ & \begin{tabular}{|l|} 
PEC \\
\end{tabular} & \begin{tabular}{|c|} 
EERP \\
\end{tabular} & EEcA & \\
\hline \multicolumn{2}{|c|}{ Modelo de gestão e governança } & \multicolumn{3}{|c|}{$\begin{array}{l}\text { Fundação para a Conservação e Produção Florestal do Estado de } \\
\qquad \text { São Paulo (FF) }\end{array}$} & Instituto Florestal (IF) & $\begin{array}{c}\text { Órgãos governamentais detêm a } \\
\text { autoridade e responsabilidade geral } \\
\text { pela gestão das UCs. Esse modelo } \\
\text { apresenta menor flexibilidade, } \\
\text { limitações orçamentárias e } \\
\text { gerenciais. }\end{array}$ \\
\hline \multirow{4}{*}{$\begin{array}{l}\text { Recursos } \\
\text { financeiros }\end{array}$} & \multirow[b]{2}{*}{$\underline{\text { Dos últimos } 5 \text { anos }}$} & $\begin{array}{r}\text { Os recursos financeiros são } \\
\text { da FF, compensações ambie } \\
\text { de ingressos e comercial } \\
\text { passaportes para o Projeto “" } \\
\text { Paulo”. }\end{array}$ & $\begin{array}{l}\text { provenientes } \\
\text { Atais, cobrança } \\
\text { ização dos } \\
\text { Trilhas de São }\end{array}$ & \begin{tabular}{|c|} 
Os recursos \\
financeiros são \\
provenientes da FF e \\
compensações \\
ambientais. \\
\end{tabular} & $\begin{array}{l}\text { Os recursos financeiros são } \\
\text { provenientes do IF e } \\
\text { compensações ambientais. }\end{array}$ & \multirow{4}{*}{$\begin{array}{c}\text { De maneira geral, verifica-se que os } \\
\text { processos para obtenção de recursos } \\
\text { para o desenvolvimento dos } \\
\text { Programas de Manejo são pouco } \\
\text { ágeis e passam por diversas } \\
\text { burocracias por parte dos órgãos } \\
\text { gestores. As fontes de recursos } \\
\text { financeiros são oriundas apenas do } \\
\text { Governo. }\end{array}$} \\
\hline & & $\begin{array}{l}\text { A gestão não apresenta } \\
\text { uma opinião formada sobre } \\
\text { os recursos financeiros } \\
\text { terem sido suficientes para } \\
\text { a realização de ações de } \\
\text { manejo críticas. } \\
\end{array}$ & Insuficientes & Suficientes & Insuficientes & \\
\hline & Dos próximos 5 anos & $\begin{array}{l}\text { A gestão não apresenta } \\
\text { uma opinião formada se os } \\
\text { recursos financeiros serão } \\
\text { suficientes para a } \\
\text { realização de ações de } \\
\text { manejo críticas. } \\
\end{array}$ & Insuficientes & Suficientes & Insuficientes & \\
\hline & $\underline{\text { Possibilidade de concessões }}$ & $\begin{array}{l}\text { Atualmente não há possi } \\
\text { concessões. Contudo, está er } \\
\text { emenda aglutinativa ao pr } \\
\text { Estadual nº } 249 / 2013 \text {, qu } \\
\text { Governo Estadual a abrir } 1 \\
\text { concessões em parques est } \\
\text { Paulo, dentre eles, o PE }\end{array}$ & $\begin{array}{l}\text { oilidades de } \\
\text { n andamento a } \\
\text { ojeto de Lei } \\
\text { autoriza o } \\
\text { icitação para } \\
\text { duais de São } \\
\text { J e o PEC. }\end{array}$ & \multicolumn{2}{|c|}{ Não há possibilidades de concessões. } & \\
\hline
\end{tabular}




\begin{tabular}{|c|c|c|c|c|c|}
\hline \multirow{2}{*}{ CARACTERÍSTICAS } & \multicolumn{4}{|c|}{ UCS URBANAS DO ESTADO DE SÃO PAULO } & \multirow{2}{*}{ OBSERVAÇÕES } \\
\hline & PEJ & PEC & EERP & EEcA & \\
\hline Recursos humanos & \multicolumn{2}{|l|}{ Insuficientes } & Suficientes & Insuficientes & $\begin{array}{l}\text { Foram considerados insuficientes pelas } \\
\text { equipes de gestão, com exceção da } \\
\text { EERP (nota-se que possui o maior } \\
\text { orçamento anual nos últimos anos, } \\
\text { quando comparada com as demais). }\end{array}$ \\
\hline \multirow[b]{2}{*}{ Participação da sociedade civil } & \multicolumn{4}{|c|}{$\begin{array}{l}\text { Reuniões dos Conselhos Consultivos para o atendimento das demandas das câmaras técnicas e } \\
\text { realização de atividades de educação ambiental com a população visitante da UC. }\end{array}$} & \multirow{2}{*}{$\begin{array}{l}\text { Ressalta-se que não foram verificadas } \\
\text { reuniões do Conselho Consultivo } \\
\text { durante o ano de } 2016 \text { para a EERP. }\end{array}$} \\
\hline & $\begin{array}{l}\text { Presença de poucos voluntários } \\
\text { ligados ao Programa Amigos do } \\
\text { Verde, composto majoritariamente } \\
\text { por estudantes que participam das } \\
\text { atividades de Uso Público. }\end{array}$ & \multicolumn{3}{|c|}{ Não há voluntários e grupos de apoio. } & \\
\hline \multirow[t]{2}{*}{$\begin{array}{l}\text { Estratégias de comunicação e } \\
\text { divulgação das informações } \\
\text { relacionadas às UCs }\end{array}$} & \multicolumn{4}{|c|}{$\begin{array}{l}\text { Informações usuais disponibilizadas aos visitantes no website da FF e CNUC, com poucas } \\
\text { informações de cunho mais específico (e.g. importância biológica e social da UC). Não há um } \\
\text { website interativo. Uso de mídias locais (jornal, rádio e TV) para divulgação de notas e } \\
\text { informações importantes. }\end{array}$} & \multirow[t]{2}{*}{$\begin{array}{l}\text { Verificam-se muitas informações } \\
\text { desatualizadas nos canais de } \\
\text { comunicação utilizados e poucas } \\
\text { estratégias de comunicação e } \\
\text { divulgação das informações. }\end{array}$} \\
\hline & $\begin{array}{l}\text { Não foram verificadas estratégias de } \\
\text { divulgação e comunicação em mídias } \\
\text { sociais. }\end{array}$ & $\begin{array}{l}\text { Atividades } \\
\text { desenvolvidas no } \\
\text { PEC são divulgadas } \\
\text { em mídia social. } \\
\end{array}$ & \multicolumn{2}{|c|}{$\begin{array}{c}\text { Não foram verificadas } \\
\text { estratégias de divulgação e } \\
\text { comunicação em mídias sociais. }\end{array}$} & \\
\hline
\end{tabular}

Fonte: Elaborado pela autora (2016). 
No presente Capítulo são apresentados quatro casos de estudos, os quais possuem grande relevância para os seus territórios, dentre as razões, por abrigarem recursos naturais importantes e fornecerem serviços ecossistêmicos para a população urbana. Contudo, mostraram-se estar pressionados e ameaçados por diversas atividades, dentre elas, destaca-se o desenvolvimento urbano do seu entorno, compromentendo portanto os seus objetivos de conservação.

A existência de diversos problemas em áreas protegidas urbanas demonstra que as cidades colocam muita pressão sobre os ecossistemas (OLIVEIRA; BALABAN; DOLL, 2001). Para os casos de estudo do presente capítulo, observou-se a ocorrência de uma série de pressões e ameaças urbanas, resultados que corroboram com os estudos de Mcneely (1995; 2001), Mcdonald, Kareiva, Forman (2008), Mcdonald et al. (2009), Mello-Thery e Correia (2009) e Trzyna (2014), os quais listam diversas pressões e ameaças enfrentadas por UCs localizadas em zonas urbanas ou de expansão urbana.

Foram verificadas pressões comuns aos quatro casos de estudo, variando em graus de intensidade, tais como desenvolvimento urbano, presença de estradas, rodovias e ferrovias, espécies exóticas invasoras, ocorrência de incêndios florestais, crimes, disposição irregular de resíduos, conflitos entre humanos e animais selvagens e poluição sonora. Além disso, observa-se que as mesmas pressões identificadas irão continuar nos próximos cinco anos, bem como novas ameaças poderão ocorrer conforme o avanço da área urbana, tais como poluição atmosférica, estabelecimento de LTs e poluição visual. Essas informações dialogam com os resultados de Mcdonald et al. (2009), os quais concluem que muitas áreas protegidas já estão sendo impactadas pelas áreas urbanas, assim como muitas outras irão ser impactadas no futuro, conforme o aumento da proximidade com estas zonas.

As pressões com maior grau de intensidade, isto é, aquelas que necessitam serem priorizadas pelas equipes de gestão são identificadas para cada UC. Para as UCs totalmente inseridas na malha urbana, como o PEC e o PEJ, apresentam como pressões mais severas o desenvolvimento urbano, as mudanças climáticas, a poluição atmosférica e a presença de estradas e rodovias como as mais severas. Muito provavelmente essas pressões se repetem nos dois casos de estudo devido a proximidade dos parques e por estarem inseridos na RMSP. Além disso, o PEC também apresentou outras pressões que necessitam prioridade, tais como a existência de ocupações ilegais, crimes e espécies exóticas. 
Para as UCs urbanas que não estão totalmente inseridas na malha urbana (EERP e EEcA), isto é, aquelas que estão localizadas na direção da expansão urbana das cidades, constata-se outros tipos de pressões mais severas. Na EERP, a ocorrência de incêndios, o desenvolvimento urbano e espécies exóticas invasoras devem ser priorizados. Já para a EEcA, as prioridades devem ser em relação à caça ilegal, a presença do aterro sanitário ainda não encerrado e resíduos gerais nas proximidades da UC, bem como a expansão agrícola em sua direção. Logo, as UCs totalmente inseridas na malha urbanas (PEJ e PEC) apresentaram estar sofrendo maior número de pressões e em maior grau de intensidade, se comparadas com as demais (EERP e EEcA). Esses resultados confirmam aqueles encontrados por Mcdonald et al. (2009), os quais alegam que os tipos de ameaças correlacionam-se significativamente com a proximidade com uma área urbana.

Verificam-se diversas iniciativas empregadas pelas equipes de gestão dos quatro casos de estudos, para mitigarem as principais pressões e ameaças encontradas. Todas as ações de conservação relatadas nos resultados são organizadas e estruturadas em categorias, de acordo com as suas diferentes finalidades (proteção, manejo, operacionalização, integração, uso público e conhecimento), a fim de se obter uma melhor compreensão sobre as diferentes iniciativas (quadro 9). As categorias criadas foram baseadas nos temas dos Programas de Manejo das UCs do presente estudo, sugeridos na revisão do Roteiro Metodológico de Planejamento das UCs de proteção integral (FERNANDES; HANGAE; MOTA, 2011). Desse modo, é importante ressaltar que a organização das ações em diferentes categorias é subjetiva, visto que as iniciativas listadas podem também se enquadrar em demais categorias e se inter-relacionar. Além disso, ressalta-se que todas as iniciativas listadas no quadro 9 foram aquelas relatadas pelos respectivos gestores, podendo haver outras ações que não foram relatadas durante as entrevistas. 
Quadro 9. Quadro síntese das ações de conservação identificadas para o PEJ, PEC, EERP e EEcA, distribuídas em categorias e subcategorias, segundo as suas finalidades. Legenda: o símbolo " $\sqrt{ }$ " representa que a UC adotou a iniciativa; nenhum símbolo representa que a UC não relatou a adoção da iniciativa durante a entrevista; o símbolo "_" significa que a iniciativa não foi adotada pois não condiz com os objetivos da UC.

\begin{tabular}{|c|c|c|c|c|c|c|}
\hline CATEGORIAS & SUBCATEGORIAS & INICIATIVAS & PEJ & PEC & EERP & EEcA \\
\hline \multirow{8}{*}{ PROTEÇÃO } & \multirow{5}{*}{ Fiscalização } & $\begin{array}{l}\text { Manifestar através de pareceres técnicos: orientações, restrições e permissões para } \\
\text { planos e projetos gerais, que possam trazer impactos prejudiciais significativos à } \\
\text { área protegida. }\end{array}$ & $\checkmark$ & $\checkmark$ & $\mathrm{V}$ & $\mathrm{V}$ \\
\hline & & $\begin{array}{l}\text { Fiscalizar e monitorar o território e seus limites, por meio do programa da Secretaria } \\
\text { Estadual de Meio Ambiente (SMA), Sistema Integrado de Monitoramento (SIM). } \\
\text { As ações de fiscalização ocorrem conforme planejamento e em conjunto com a } \\
\text { Coordenadoria de Fiscalização Ambiental da SMA e Policiamento Ambiental. }\end{array}$ & $\checkmark$ & $\mathrm{V}$ & V & V \\
\hline & & $\begin{array}{l}\text { Acionar agências locais ou regionais quando necessário (e.g. agências de limpeza, } \\
\text { Polícia Militar, Guarda Civil Metropolitana, CETESB, etc.). }\end{array}$ & V & 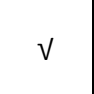 & V & V \\
\hline & & $\begin{array}{l}\text { Fiscalizar e notificar os indivíduos pegos em atividades conflitantes com os } \\
\text { objetivos de conservação da área. }\end{array}$ & $\checkmark$ & $\checkmark$ & & \\
\hline & & Identificar, apreender os barramentos ilegais e realizar laudos de danos ambientais. & $\checkmark$ & $\checkmark$ & - & - \\
\hline & \multirow{3}{*}{$\begin{array}{l}\text { Prevenção e combatea } \\
\text { incêndios florestais }\end{array}$} & $\begin{array}{l}\text { Prevenir, monitorar, controlar e combater incêndios florestais (e.g. Operação Corta } \\
\text { Fogo - ações coordenadas em conjunto pela Secretaria de Meio Ambiente, Casa } \\
\text { Militar-Defesa Civil, Corpo de Bombeiros, Policia Militar Ambiental e Municípios). }\end{array}$ & 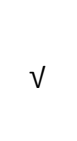 & $v$ & V & V \\
\hline & & Acionar agências de policiamento para os casos de incêndios criminosos. & V & $v$ & V & V \\
\hline & & $\begin{array}{l}\text { Auxiliar na implementação de um programa de manutenção das margens das } \\
\text { rodovias, em parceria com o Departamento de Estradas de Rodagem (DER). }\end{array}$ & V & $v$ & V & V \\
\hline
\end{tabular}




\begin{tabular}{|c|c|c|c|c|c|c|}
\hline CATEGORIAS & SUBCATEGORIAS & INICIATIVAS & PEJ & PEC & EERP & EEcA \\
\hline \multirow{13}{*}{ MANEJO } & \multirow{10}{*}{ Habitats } & Promover conexões com outras áreas naturais. & & $\mathrm{V}$ & $\mathrm{V}$ & \\
\hline & & $\begin{array}{l}\text { Fomentar e orientar os responsáveis a implementar medidas gerais de compensação } \\
\text { ambiental (e.g. instalação de redutores de velocidade; sinalização nas estradas; resgate e } \\
\text { realocação de vegetação de importante valor biológico, para áreas de menor } \\
\text { biodiversidade; plantio de mudas nativas no interior da UC; passagens de fauna). }\end{array}$ & $\checkmark$ & V & V & V \\
\hline & & $\begin{array}{l}\text { Evitar resíduos (e.g. acondicioná-los em lixeiras, destiná-los ao sistema de coleta } \\
\text { público, limpeza por parte de equipe de manutenção terceirizada). }\end{array}$ & v & V & V & V \\
\hline & & Aproveitar os resíduos orgânicos provenientes de material de poda para uso na UC. & & $\mathrm{V}$ & & \\
\hline & & $\begin{array}{l}\text { Utilizar lixeiras com aberturas menores para se evitar a retirada por parte dos animais e } \\
\text { possível contaminação da fauna silvestre nas trilhas). }\end{array}$ & v & V & & \\
\hline & & Fomentar a reutilização e recicláveis dos resíduos. & $\mathrm{V}$ & & & \\
\hline & & $\begin{array}{l}\text { Regularizar os sistemas de tratamento de esgoto, garantindo a proteção dos recursos } \\
\text { hídricos da UC. }\end{array}$ & 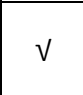 & V & V & \\
\hline & & $\begin{array}{l}\text { Recuperar áreas degradadas (e.g. contenção da emissão de efluentes clandestinos, } \\
\text { revitalização e desassoreamento dos corpos d'água relacionados à UC). }\end{array}$ & v & V & & \\
\hline & & $\begin{array}{l}\text { Criar e executar planos de recuperação da flora e fauna em áreas degradadas no interior } \\
\text { da UC. }\end{array}$ & & & $\mathrm{V}$ & \\
\hline & & $\begin{array}{l}\text { Solicitar manutenções periódicas (para com os responsáveis) nos locais de interferência } \\
\text { de LTs como medidas preventivas contra acidentes. }\end{array}$ & & V & - & \\
\hline & \multirow{3}{*}{ Espécies } & Detectar e monitorar espécies exóticas invasoras de flora. & $\mathrm{V}$ & $\mathrm{V}$ & $\mathrm{V}$ & $\mathrm{V}$ \\
\hline & & $\begin{array}{l}\text { Erradicar espécies exóticas invasoras de flora, com recursos de compensação ambiental } \\
\text { de empreendimentos potencialmente impactantes. }\end{array}$ & & V & v & $\checkmark$ \\
\hline & & Encaminhar cães e gatos domésticos para o Centro de Zoonoses do município. & & $\mathrm{V}$ & & \\
\hline
\end{tabular}




\begin{tabular}{|c|c|c|c|c|c|c|}
\hline CATEGORIAS & SUBCATEGORIAS & INICIATIVAS & PEJ & PEC & EERP & EEcA \\
\hline \multirow{4}{*}{ OPERACIONALIZAÇÃO } & $\begin{array}{c}\text { Cooperação } \\
\text { interinstitucional }\end{array}$ & $\begin{array}{l}\text { Articular com diferentes instituições: acompanhar e participar de } \\
\text { discussões de políticas ambientais, planos territoriais, etc. }\end{array}$ & V & $\mathrm{V}$ & $\mathrm{V}$ & $\checkmark$ \\
\hline & \multirow{3}{*}{$\begin{array}{l}\text { Infraestrutura e } \\
\text { equipamentos }\end{array}$} & $\begin{array}{l}\text { Sinalizar o interior e entorno da área protegida (e.g. distribuição de placas, } \\
\text { folders e banners informativos). }\end{array}$ & 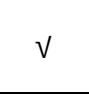 & V & V & $\checkmark$ \\
\hline & & Criar facilidades para os visitantes. & $\mathrm{V}$ & $\mathrm{V}$ & - & - \\
\hline & & Capacitar os funcionários & $\mathrm{V}$ & $\mathrm{V}$ & $\mathrm{V}$ & \\
\hline \multirow{3}{*}{ INTEGRAÇÃO } & \multirow{2}{*}{$\begin{array}{l}\text { Sensibilização } \\
\text { ambiental }\end{array}$} & $\begin{array}{l}\text { Sensibilizar a população do entorno através de atividades de educação } \\
\text { ambiental (e.g. projetos de educação ambiental com a comunidade do } \\
\text { entorno - população, proprietários, empresas, indústrias vizinhas). }\end{array}$ & V & $\mathrm{V}$ & & \\
\hline & & $\begin{array}{l}\text { Divulgar informações sobre as restrições de uso da ZA nos fóruns do } \\
\text { município; }\end{array}$ & & & & V \\
\hline & $\begin{array}{l}\text { Comunicação e } \\
\text { divulgação }\end{array}$ & $\begin{array}{l}\text { Divulgar informações importantes relacionadas à área protegida (e.g. } \\
\text { cartilhas de educação ambiental, sites). }\end{array}$ & $\mathrm{V}$ & V & V & $\checkmark$ \\
\hline \multirow{6}{*}{ USO PÚBLICO } & \multirow{2}{*}{ Interpretação ambiental } & $\begin{array}{l}\text { Sensibilizar o público visitante através de atividades de educação } \\
\text { ambiental. }\end{array}$ & $\mathrm{V}$ & V & V & \\
\hline & & $\begin{array}{l}\text { Orientar os visitantes sobre os usos permitidos e não permitidos na área } \\
\text { protegida. }\end{array}$ & V & $\mathrm{V}$ & - & - \\
\hline & \multirow{4}{*}{ Recreação e Lazer } & Promover atividades turísticas e recreativas de baixo impacto ambiental. & $\mathrm{V}$ & $\mathrm{V}$ & - & - \\
\hline & & Controlar o número de visitantes. & $\mathrm{V}$ & $\mathrm{V}$ & - & - \\
\hline & & Concentrar atividades de uso público (e.g. criação de zonas recreativas). & $\mathrm{V}$ & $\mathrm{V}$ & - & - \\
\hline & & $\begin{array}{l}\text { Elaborar planos de negócios (e.g. identificar áreas com potencial para } \\
\text { exploração de atividades ecoturísticas e oferecimento de serviços para os } \\
\text { usuários - para as UCs que permitem visitação) }\end{array}$ & & V & - & - \\
\hline \multirow{4}{*}{ CONHECIMENTO } & \multirow{3}{*}{ Pesquisa } & Fomentar pesquisas científicas. & $\mathrm{V}$ & $\mathrm{V}$ & $\mathrm{V}$ & $\mathrm{V}$ \\
\hline & & $\begin{array}{l}\text { Facilitar parcerias com instituições educacionais (e.g. universidades, } \\
\text { instituições de pesquisa, etc.). }\end{array}$ & $\mathrm{V}$ & $\mathrm{V}$ & $\mathrm{V}$ & V \\
\hline & & $\begin{array}{l}\text { Fomentar pesquisas periódicas com os visitantes (e.g. contagem de } \\
\text { indivíduos, pesquisar sobre o conhecimento dos visitantes sobre a área } \\
\text { protegida, locais e usos mais frequentes, etc.). }\end{array}$ & & V & - & - \\
\hline & Monitoramento & $\begin{array}{l}\text { Promover um programa de monitoramento da fauna e flora (e.g. espécies } \\
\text { protegidas, exóticas invasoras). }\end{array}$ & $\mathrm{V}$ & $\mathrm{V}$ & $\mathrm{V}$ & $\mathrm{V}$ \\
\hline
\end{tabular}

Fonte: Elaborado pela autora (2016), baseado nas informações obtidas nas entevistas realizadas com os gestores. 
As ações de proteção foram subdivididas em ações de fiscalização e prevenção e combate a incêndios florestais. De maneira geral, são aquelas direcionadas para a proteção dos recursos da UC, isto é, de atividades incompatíveis com os seus objetivos, infrações ambientais e demais atividades que possam comprometer a integridade do seu patrimônio. Logo, observa-se que a fiscalização é o principal instrumento do Programa de Proteção das UCs e as equipes de gestão alegam que a presença de vigilantes é uma boa estratégia para coibir atos de infração nesses locais. Ainda assim, observa-se que a maior parte dos vigilantes são contratados por empresas terceirizadas, que demandam maior parte dos recursos financeiros das UCs. As empresas contratadas para vigilância têm caráter de proteção patrimonial, com poucos treinamentos e capacitação voltados para a "vigilância ambiental" do local. Conforme sugerido pela Secretaria de Meio Ambiente (SÃO PAULO, 2009), é importante que todos os funcionários estejam familiarizados com as normas e temáticas ambientais específicas das UCs. Em especial à EEcA, a fiscalização é considerada insuficiente e mal preparada pela equipe de gestão.

Também se observam ações de manejo, subdivididas em habitats e espécies. Esse tipo de ação inclui as iniciativas que visam manter os recursos naturais e culturais presentes nas UCs, e que de certa forma estão sendo pressionados por atividades conflitantes. Dentre as ações desta categoria, destacam-se aquelas que visam a promoção de conexões e incremento de áreas verdes no entorno das UCs, evitando a fragmentação causada pelo ambiente urbano. Contudo, observamse poucas iniciativas se considerar a gravidade das pressões do entorno e o cenário de isolamento em que se encontram, em especial para as UCs totalmente inseridas na malha urbana. Desse modo, a falta de conectividade poderá gerar problemas sérios, dentre eles, a ausência de fluxo gênico entre as espécies, levando à extinção.

Segundo alguns autores (SAUNDERS; HOBBS; MARGULES, 1991; CROUZEILLES; LORINI; GRELLE, 2013) a conectividade funcional dos ecossistemas é representada pelas respostas do movimento dos animais aos elementos paisagísticos e deve ser considerada no desenho e planejamento das áreas protegidas, havendo uma forte necessidade em se desenvolver uma abordagem integrada à gestão da paisagem, que coloque as áreas protegidas no contexto da paisagem global. Além disso, um fortalecimento das articulações com outras instituições do território em prol dessas UCs, bem como mudanças nas legislações podem contribuir para aumentar a implantação de áreas verdes e parques lineares próximo às áreas protegidas urbanas. 
Outra observação é que o território das UCs urbanas e suas ZAs são consideradas zonas rurais pelo SNUC, fato altamente incompatível com a realidade observada nessas áreas e evidenciadas pelos casos de estudos. Também verifica-se que não há uma categoria explícita e uma definição própria para as UCs urbanas na legislação do país. Logo, mudanças em relação a essas questões podem garantir um maior amparo legal e consequentemente uma maior proteção para essas unidades.

As ações de operacionalização visam o fortalecimento das relações interinstitucionais que envolvem direta ou indiretamente às UCs, e subdividem-se nas categorias de cooperação institucional, infraestrutura e equipamentos (quadro 9). Essas últimas, possuem como finalidade a manutenção das funções operacionais das UCs, relacionadas às questões de infraestrutura, equipamentos, recursos humanos, entre outros. Desse modo, observa-se que o quadro de recursos humanos PEJ e da EEcA não propiciam um manejo adequado das UCs. De maneira geral, o número de funcionários não é suficiente, existe uma rotatividade de funcionários, dificultando a continuidade das ações. Especificamente para a EEcA, a situação é ainda mais agravante, pois além do quadro ser escasso, não há oportunidades de capacitação e desenvolvimento apropriadas às suas necessidades. Logo, conforme destacado por Guimarães e Pellin (2015), as demandas e desafios das UCs urbanas tendem a se acentuar quando comparadas com as UCs mais remotas, sendo necessário uma melhora nesse quesito.

Os recursos financeiros das UCs do presente capítulo se mostraram insuficientes para atender as as necessidades básicas, com exceção da EERP. Além disso, a morosidade nos processos de solicitações de recursos financeiros dos órgãos gestores, observados nos modelos de gestão estatal, contribui para a dificuldade na execução dos programas de manejo. Desse modo, as UCs vêm buscando recursos advindos de compensações ambientais como solução para a implementação das ações propostas.

Outro tipo de categoria observada são ações de integração, as quais, de maneira geral, apresentam como objetivo envolver e integrar os indivíduos que compõem os territórios com as UCs, de modo a fortalecer as relações entre estes e aumentar a consciência sobre a importância em se manter essas áreas. A subcategoria sensibilização ambiental agrupa as ações que buscam conscientizar as comunidades que se relacionam com as UCs, através de projetos de educação ambiental e diálogos em fóruns de discussões, a fim de se desenvolver e aumentar a consciência crítica sobre a problemática ambiental. As iniciativas dessa subcategoria destinaram-se às 
comunidades vizinhas e atores sociais importantes nas tomadas de decisões dos municípios. Logo, observam-se diversas iniciativas, tais como a divulgação sobre as restrições de uso da ZA nos fóruns do município, projetos de educação ambiental com a comunidade do entorno, bem como orientações e sensibilização de proprietários nas áreas limítrofes às UCs. Segundo Trzyna (2014), ações desse tipo são fundamentais para as áreas protegidas urbanas, ações que possibilitam um aumento da percepção ambiental da população urbana sobre a importância desses locais para as cidades, bem como sobre os problemas complexos que envolvem essas áreas.

A subcategoria comunicação e divulgação tem como objetivo aumentar a visibilidade das UCs, através da divulgação das atividades desenvolvidas no seu interior em diversos veículos de mídia, buscando atingir diferentes tipos de públicos e promover uma maior interação com as comunidades que se relacionam com as UCs. Além disso, tem como objetivo fortalecer as identidades das UCs. Contudo, as estratégias de comunicação e divulgação são escassas e pouco interativas com o público, onde na maioria das vezes verifica-se a ausência de informações mais específicas nos bancos de dados sobre as UCs, bem como um déficit em pessoal capacitado para trabalhar nessa área. De maneira geral, não há conteúdos mais específicos sobre esses locais, bem como grande parte das informações encontra-se desatualizada. Para que a população se integre melhor aos processos de tomada de decisões nesses locais, um direcionamento dos recursos para a promoção dessas áreas torna-se necessário, tais como a contratação de funcionários voltados para a comunicação e marketing das UCs, bem como o uso de novas estratégias (e.g. criação de um website próprio, atualização de informações em mídias sociais, aplicativos, etc.).

Verificam-se ações de uso público, as quais visam ordenar, direcionar e orientar o uso das UCs por parte do público. Reúne as atividades que apresentam como objetivo sensibilizar os visitantes sobre as questões ambientais e o papel das UCs, explorar atividades de recreação e lazer, visando a qualidade de vida da comunidade, bem como proporcionar condições adequadas para o estabelecimento dessas ações. De maneira geral, para as UCs que permitem visitação, observa-se a promoção de atividades turísticas e recreativas de baixo impacto e um controle do número de visitantes, visando a ordenação do espaço. Além disso, a partir da elaboração de planos de negócios, será possível identificar as áreas com potencial para a exploração de atividades ecoturísticas e oferecimento de serviços para os visitantes (e.g. lanchonetes), os quais são escassos atualmente. Contudo, ressalta-se como de fundamental importância um planejamento participativo 
e cuidadoso das atividades que serão exploradas, levando em consideração que a prioridade das UCs é a conservação da biodiversidade in situ.

Nesse sentido, para os casos dos parques, existe uma clara confusão com a categoria de parque urbano, a qual prioriza atividades de lazer e recreação em detrimento da conservação da biodiversidade. Esse fato pode ser explicado pela inexistência de uma identidade forte das UCs, bem como pela baixa conscientização ambiental da população urbana, onde muitas vezes o público não reconhece que essas áreas são protegidas e amparadas legalmente, desconhece de seus objetivos específicos e muito menos das possibilidades e mecanismos de participação.

Os casos de estudo analisados apresentam importância biológica e cultural para os seus territórios, ressaltando a relevância em se preservar esses patrimônios. Como por exemplo, o PEJ possui em seu território um patrimônio histórico-cultural (Casarão Afonso Sardinha) de grande potencial educativo a ser explorado, o qual necessita urgentemente de restauração para tanto. Além disso, os casos de estudos evidenciam o que a literatura diz sobre a importância de espaços de integração da sociedade urbana com o meio ambiente, em regiões onde as áreas naturais de floresta são escassas (TRYZNA, 2014). Nesse sentido, a procura por esses espaços para a realização de atividades de recreação e lazer é grande e irá aumentar segundo as tendências futuras de expansão urbana e crescimento populacional verificadas.

As ações de conhecimento proporcionam subsídios para a proteção e o manejo dos recursos naturais, sendo uma das principais ferramentas para o estabelecimento das ações de manejo. Logo, se referem aos estudos, pesquisas científicas e ao monitoramento ambiental a serem desenvolvidos na UC. Desse modo, observa-se que os casos de estudos do presente Capítulo buscam fomentar pesquisas científicas, estabelecer parcerias com instituições educacionais (e.g. universidades, instituições de pesquisa, etc.) e programas de monitoramento da fauna e flora. A FF e o IF possuem conselhos técnico-científicos para realizar essas tarefas, bem como para analisar e autorizar as pesquisas em seus territórios. Contudo, observa-se um descaso de alguns pesquisadores e dificuldades de comunicação entre as equipes de gestão e estes, os quais muitas vezes não mostram os resultados obtidos em suas pesquisas.

Os planos de manejo analisados no presente estudo foram baseados no Roteiro Metodológico de Planejamento (FERNANDES; HANGAE; MOTA, 2011), os quais ressaltam a importância de serem dinâmicos, adaptativos e participativos em todas as etapas do ciclo de gestão das UCs. Não obstante, de acordo com a política ambiental vigente no país, cada UC de proteção 
integral deve dispor de Conselhos Consultivos, presidido pelo órgão responsável por sua administração e constituído por representantes de órgãos públicos e de organizações da sociedade civil em geral, funcionando como espaços de participação social (BRASIL, 2000). Contudo, observa-se que o envolvimento da população urbana na gestão participativa das UCs do presente estudo ainda é incipiente, visto a baixa adesão de grupos de apoio, voluntariado e participação nos Conselhos Consultivos, bem como as articulações institucionais variam em intensidade nas diferentes UCs. Esses resultados dialogam com aqueles obtidos por Agnes (2015), os quais mostram que o respaldo institucional, garantido pela existência de Conselhos não se traduz por si só em participação social na gestão destes territórios, bem como verifica-se um reduzido número de conselhos gestores ativos para as UCs do país. Nesse contexto, os Conselhos Consultivos ainda possuem desafios para serem efetivamente ativos, principalmente devido ao histórico do país em que as vontades políticas dos grandes setores de infraestrutura tendem a prevalecer sobre as questões ambientais.

Somado a esses fatos, observa-se que os gestores são figuras importantes e altamente centralizadas no processo de gestão das UCs do presente Capítulo. Como consequência do modelo de gestão estatal, observa-se que algumas respostas obtidas pelas gestões geraram incertezas. Como por exemplo, em relação aos recursos humanos da EERP, verifica-se que a gestão considera-os adequados para o manejo efetivo da UC. Contudo, é importante observar que a área conta com apenas quatro funcionários, responsáveis por uma área de 154 ha, a qual sofre inúmeras pressões e ameaças no seu entorno, comentadas a seguir.

Outro exemplo de incerteza ocorre em relação à poluição hídrica da UC. A gestão adverte que esta é uma pressão leve. Contudo, segundo o Plano de Manejo (2009) e a partir da interpretação das classes de uso do solo do entorno da Mata ${ }^{51}$, verifica-se que as microbacias hidrográficas que formam o Córrego da Serraria são intensamente usadas na produção canavieira, bem como suas nascentes e trechos do Córrego a montante da EERP apresentam proteção florestal variada, ora sem resquícios de vegetação ciliar, ora com vegetação pouco mais desenvolvida. Desse modo, grande parte das Áreas de Preservação Permanente (APPs) são ocupadas por atividades agropecuárias ou encontram-se desflorestadas, implicando em prejuízos a qualidade das águas que cortam a EERP e de seu entorno. Ademais, dados levantados por Varanda et al. (2015) mostram que a ZA apresenta-se extremamente fragmentada, com uma biodiversidade típica de áreas

\footnotetext{
${ }^{51}$ Através das imagens de satélite fornecidas pelo software Google Earth (data das imagens: 13/04/2016).
} 
degradadas, e com a presença de espécies ameaçadas de extinção (e.g. jaguatirica - Leopardus pardalis, lobo-guará - Chrysocyon brachyurus e onça-parda - Puma concolor), ocasionadas pela expansão urbana e agropecuária da região. Durante a entrevista, também não foi considerado que a expansão agrícola nos últimos anos tenha sido prejudicial ou impactante para a ZA da EERP, mesmo constando no Plano de Manejo que as áreas da microbacia da Serraria são utilizadas para o cultivo da cana-de-açúcar, onde as práticas de manejo (e.g. uso de defensivos no controle de pragas) são potencialmente causadoras de impactos ambientais.

Logo, a figura altamente centralizada do gestor, a baixa transparência e participação social nos processos de tomada de decisão são limitantes para que a gestão dessas áreas seja adequada. Desse modo, é fundamental promover o empoderamento dos Conselhos para que estes funcionem efetivamente como fóruns de discussão e participação, e não apenas para atender as demandas mais urgentes das câmaras técnicas.

\section{Considerações Finais}

Diversas pressões e ameaças foram identificadas e avaliadas pelas gestões dos quatro casos de estudos do presente Capítulo, tais como: desenvolvimento urbano do entorno; estradas e rodovias; poluição atmosférica; mudanças climáticas; espécies exóticas invasoras; incêndios; ocupações ilegais; crimes; disposição de resíduos; caça ilegal; poluição hídrica; extração de recursos; atividades religiosas; disputas sobre o uso d'água; conflitos entre humanos e animais selvagens; LTs; turismo e recreação; poluição sonora e visual; atividades industriais e por fim, mineração.

A fim de conter essas pressões e ameaças, as gestões das UCs do presente Capítulo vêm implementando diversas ações de conservação, tais como ações que visam a proteção (e.g. fiscalização e monitoramento do território por meio do Sistema Integrado de Monitoramento SIM), manejo dos recursos naturais (e.g. controle de espécies exóticas invasoras), operacionalização (e.g. articulação com diferentes instituições), integração com o entorno (e.g. sensibilização da população do entorno da UC), ações voltadas para o uso público (e.g. promoção de atividades turísticas e recreativas de baixo impacto ambiental) e produção de conhecimento (e.g. fomento à pesquisa científica).

Desse modo, todos os casos de estudos do presente capítulo mostraram possuir tanto potencialidades como problemas a serem resolvidos. Nesse sentido, verificam-se limitações para a implementação das ações de conservação, presentes na etapa de planejamento operacional das UCs 
do presente estudo, tais como em relação aos recursos humanos, financeiros e baixo apoio e participação da população nos processos decisórios. As UCs totalmente inseridas na malha urbanas (PEJ e PEC) apresentaram estar sofrendo maior número de pressões e em maior grau de intensidade, se comparadas com as demais (EERP e EEcA). Logo, a constatação de impactos prejudiciais às UCs, bem como a possibilidade de novos efeitos negativos para os próximos anos, ressalta a importância do planejamento adequado, que seja exequível, dinâmico e participativo conforme as demandas, bem como a existência de recursos humanos e financeiros suficientes para atender as necessidades das UCs. 


\section{CAPÍTULO III. ÁREAS PROTEGIDAS URBANAS EUROPEIAS}

\section{Introdução}

Atualmente, mais da metade da população mundial vive em áreas urbanas e para as próximas décadas, as previsões mostram que todos os continentes irão se urbanizar (UNPD, 2015). Com um maior número de pessoas vivendo em ambientes urbanos, espera-se uma diminuição de vivências dessa população com ambientes naturais, resultando em uma maior vulnerabilidade das áreas protegidas, as quais requerem aliados em defesa da sua conservação (TRZYNA, 2014).

O processo de urbanização, o qual está intimamente ligado à industrialização e ao crescimento econômico, vêm resultando em mudanças profundas nas paisagens devido a depredação dos recursos naturais (ANTROP, 2004). Em suma, os impactos ocasionados por esse processo podem impedir com que as áreas protegidas cumpram com seus objetivos de conservação (TRZYNA, 2014), dentre eles, a provisão de serviços ecossistêmicos (BOLUND, HUNHAMMAR, 1999). Portanto, frente ao cenário incerto de vulnerabilidade das áreas protegidas urbanas, associado ao baixo engajamento da população e demais desafios, a conservação dos patrimônios naturais e o bem-estar das populações encontram-se comprometidos.

Para compreender como as áreas protegidas urbanas internacionais vêm resolvendo os seus problemas, áreas protegidas localizadas no continente europeu foram definidas como objetos de estudo. A escolha pelo continente europeu se deve pelo seu alto índice de urbanização, com mais de 70\% da sua população residindo em áreas urbanas (UNPD, 2015).

No passado, a rápida expansão urbana europeia, acompanhada do elevado crescimento populacional e deficiências nos processos de planejamento territorial levaram a um aumento dos problemas sociais, econômicos e ambientais, alterando profundamente a paisagem (SUNDSETH; RAEYMAEKERS, 2006). A fim de mitigá-los, foram estabelecidos na década de 80 programas de recuperação nas áreas urbanas de grandes cidades europeias (SUNDSETH; RAEYMAEKERS, 2006). Com o passar dos anos, convenções e tratados internacionais vêm desempenhando um papel fundamental na sensibilização e no estabelecimento de políticas ambientais atuais, onde observase um aumento da preocupação com as questões sociais e ambientais (SUNDSETH; RAEYMAEKERS, 2006).

Para auxiliar nas questões e desafios ambientais, criou-se a União Internacional para a Conservação da Natureza (IUCN), uma rede internacional composta de membros governamentais e organizações da sociedade civil, com especialistas diversos organizados em comissões. 
Atualmente, ela é conhecida por ser a autoridade em fornecer conhecimento, ferramentas e orientações gerais para temas relacionados à conservação da natureza, dentre eles para as áreas protegidas mundiais.

Nesse contexto, com o subsídio científico proporcionado pela IUCN e outras organizações, a Direção Geral de Meio Ambiente da União Europeia ${ }^{52}$ (UE) é responsável por propor políticas e legislações (regulações e diretivas) que visem a proteção e preservação do meio ambiente e avanço para uma economia sustentável da Europa, além de assegurar que os Estados-membros cumpram com a legislação ambiental. Desse modo, o seu principal instrumento para a conservação da biodiversidade consiste na Rede Natura 2000 (EUROPEAN COMISSION, 2016).

A Rede Natura 2000 é a maior rede de áreas protegidas do mundo, abrangendo $18 \%$ das áreas terrestres e 6\% do território marinho, com cerca de 26.000 sítios protegidos (EEA, 2015). Ela oferece proteção para as espécies e habitats mais vulneráveis na Europa, resultante da aplicação de duas diretivas específicas: a Diretiva de $\mathrm{Aves}^{53}$, a respeito da conservação das aves selvagens e a Diretiva de Habitats $^{54}$, relativa à proteção de habitats ${ }^{55}$ (EEA, 2015).

Cada país da UE é responsável por designar uma lista de áreas protegidas, cumprindo uma obrigação comunitária no âmbito da Convenção sobre a Diversidade Biológica (EEA, 2015). Para cada região biogeográfica, os Estados-membros adotam uma lista de sítios que integram áreas especiais de proteção (SPAs ${ }^{56}$ ), designadas de acordo com a Diretiva de Aves, e áreas especiais de conservação $\left(\mathrm{SACs}^{57}\right)$, designadas nos termos da Diretiva de Habitats. Os Estados-membros devem selecionar os sítios segundo critérios científicos, assegurar a designação de todos os territórios adequados e apoiar a sua gestão (EEA, 2015). Em seguida, a Comissão Europeia, analisa as propostas dos Estados-membros e decidem quais locais devem ser protegidos, através de um processo transparente, com a realização de seminários científicos (com a participação da sociedade civil e especialistas) e apoiados pela Agência Ambiental Europeia ${ }^{58}$ (EEA, 2015).

Os sítios Natura 2000 podem ser privados ou públicos e por categorias de uso indireto e direto (EEA, 2015). Isso ocorre principalmente devido à elevada densidade populacional na Europa

\footnotetext{
52 Environment Directorate General (DG Environment).

${ }^{53}$ The Birds Directive.

54 The Habitats Directive.

55 Esta rede está dividida em nove regiões biogeográficas: Alpina, Atlântica, Mar Negro, Boreal, Continental, Macaronésia, Mediterrânea, Panônica e Estépica (EEA, 2015).

56 Special Protection Areas (SPAs)

57 Special Areas of Conservation (SACs)

${ }^{58}$ European Environment Agency (EEA).
} 
e o reconhecimento de que o objetivo das áreas protegidas não é excluir as atividades antrópicas, mas garantir a sua compatibilidade com a proteção de espécies e habitats (EEA, 2015). Para isso, as gestões responsáveis devem seguir diretrizes pautadas na sustentabilidade. Além disso, qualquer proposta de desenvolvimento susceptíveis de resultar em impactos aos sítios Natura 2000 devem ser apreciadas e avaliadas caso a caso (EEA, 2015).

De acordo com as normas estabelecidas nas Diretivas, verifica-se que os Estados-membros deveriam ter apresentado as suas propostas até o ano de 1996, havendo atrasos consideráveis (EEA, 2015). Logo, a Comissão Europeia iniciou diversas ações judiciais e associou a aprovação de determinados programas de Fundos Estruturais à apresentação de listas de sítios a serem protegidos (EEA, 2015). Como resultado, observou-se um progresso significativo na proteção dos territórios (EEA, 2015).

As diretivas prevêm que a Comissão Europeia deve co-financiar custos relacionados com a gestão dos sítios, juntamente com os Estados-membros (EEA, 2015). Os recursos financeiros destinados à Rede Natura 2000 provém do fundo Life-Nature (EEA, 2015). Além disso, existe um grupo de apoio (formado por especialistas) responsável por auxiliar à Comissão.

Nesse contexto, o que faz da Rede Natura 2000 uma rede bem-sucedida de áreas protegidas? De acordo com Sundseth e Raeymaekers (2006), todos os Estados-membros têm de trabalhar em conjunto na mesma base legislativa, a fim de proteger e manter as espécies e habitats vulneráveis. Além disso, a Comissão Europeia é responsável por verificar se a legislação é seguida, através de relatórios elaborados pelos Estados-membros e informações fornecidas por cidadãos e organizações ambientais (EEA, 2015). Caso algum país não esteja cumprindo as normas estabelecidas, os países são notificados e a Comissão Europeia pode iniciar uma série de ações jurídicas, as quais podem resultar em multas elevadas (EEA, 2015). Logo, isso funciona como uma importante pressão para os países, fazendo-os instituir propostas substanciais. Além disso, a Comissão Europeia trabalha em estreita colaboração com os Estados-membros, assegurada através de Comitês, os quais fiscalizam o cumprimendo das diretivas bem como promovem encontros com os envolvidos para a discussão das principais questões que envolvem a proteção da Rede Natura 2000 (EEA, 2015). Nesse sentido, o presente Capítulo tem como objetivo apresentar três casos de estudo referente às áreas protegidas do continente europeu, avaliar suas principais pressões e ameaças, bem como analisar as ações de conservação que vêm sendo adotadas para sua mitigação. 


\section{Materiais e Método}

O processo de seleção dos casos de estudos observou os critérios a seguir (figura 25).

Figura 25. Delimitação do recorte da pesquisa, a partir de quatro critérios para seleção dos casos de estudos internacionais.

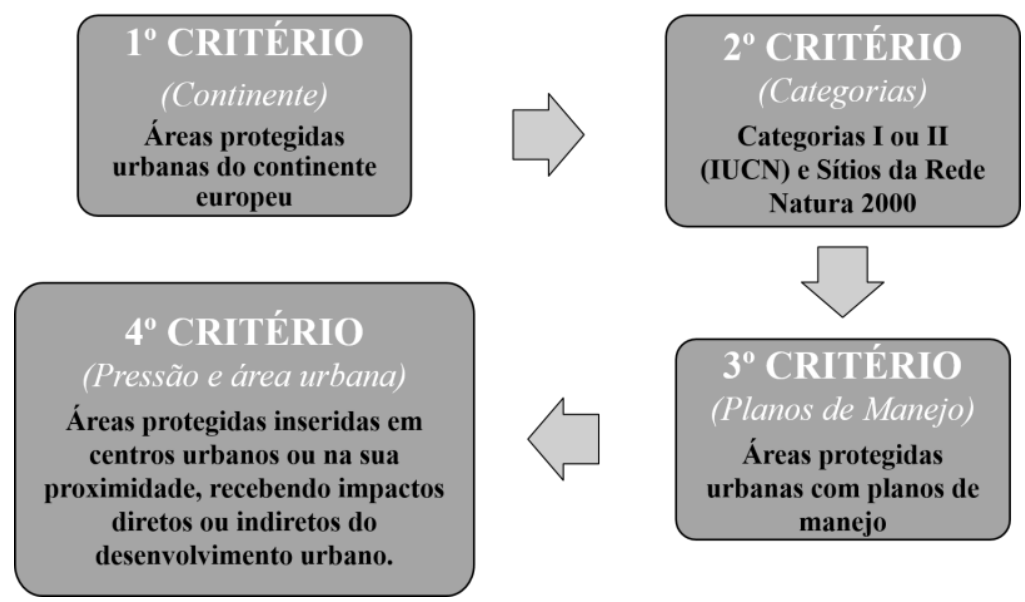

Fonte: Elaborada pela autora (2016).

Primeiramente, optou-se por áreas protegidas urbanas do continente europeu. Isso se deve pelo seu alto índice de urbanização, com mais de $70 \%$ da sua população sendo urbana (UNPD, 2015).

Como segundo critério, optou-se por áreas das categorias I ou II da IUCN e áreas pertencentes a Rede Natura 2000. Apesar de todas as categorias da IUCN serem importantes de alguma forma, a escolha pelas categorias I ou II dão especial atenção à proteção da biodiversidade e outros patrimônios naturais e culturais (DUDLEY, 2008). De maneira geral, áreas protegidas da categoria I (subdivididas em "Ia" e "Ib") são áreas reservadas a proteger a biodiversidade, ecossistemas e espécies com importantes valores ambientais e culturais e permitem a realização de pesquisas científicas, monitoramento e educação ambiental (DUDLEY, 2008). Além disso, os usos e impactos humanos são rigorosamente controlados e limitados para assegurar a proteção da área (DUDLEY, 2008). Já os parques são grandes áreas protegidas que auxiliam na conservação da biodiversidade, mas que oferecem oportunidades recreativas e turísticas para as populações (DUDLEY, 2008). 
A escolha por áreas pertencentes à Rede Natura $2000^{59}$ ocorreu por ser a maior rede de áreas protegidas do mundo, sendo considerada a peça central na conservação da biodiversidade da União Europeia.

O terceiro critério consistiu na escolha de áreas protegidas com planos de manejo, principal instrumento que estabelece as orientações e diretrizes para uma gestão adequada (LEMOS DE SÁ; FERREIRA, 2000). Logo, conforme comentado anteriormente, entende-se que na sua ausência torna-se difícil adotar ações de conservação.

Como quarto critério, optou-se por áreas protegidas inseridas em centros urbanos ou na sua proximidade, recebendo impactos diretos ou indiretos do desenvolvimento urbano. Para tanto, foi utilizado o banco de dados global ${ }^{60}$ sobre áreas protegidas terrestres e marinhas da IUCN e PNUMA, conhecido como Protected Planet ${ }^{61}$ (IUCN; UNEP-WCMC, 2015). A partir deste banco de dados, foi possível identificar uma vasta lista de as áreas protegidas pertencentes aos diferentes países europeus. Desse modo, a partir de interpretações visuais do Protected Planet e do mapa interativo da Agência Ambiental Europeia (EEA, 2013) foram escolhidas as seguintes áreas para a realização dos primeiros contatos com os gestores (quadro 10):

Quadro 10. Áreas protegidas urbanas europeias selecionadas para contato, enquadradas nos quatro critérios.

\begin{tabular}{|c|c|}
\hline ÁREAS PROTEGIDAS URBANAS & LOCALIZAÇÃO \\
\hline Sítio Natura 2000 Parque Nacional Donau-Auen & Áustria (Viena) \\
\hline Sítio Natura 2000 Parque Nacional do Vesúvio & Itália (Nápoles) \\
\hline Sítio Natura 2000 Parque Nacional das Calanques & França (Marselha) \\
\hline Sítio Natura 2000 Parque Nacional Zuid-Kennemerland & Países Baixos (Haarlem, Zandvoort, Bloemendaal e Velsen) \\
\hline Sítio Natura 2000 Sonian Forest & Bélgica (Bruxelas) \\
\hline Sítio Natura 2000 Grunewald & Alemanha (Berlim) \\
\hline Sítio Natura 2000 Lendspitz-Maiernigg & Áustria (Klagefurt) \\
\hline
\end{tabular}

Fonte: Elaborado pela autora (2016).

Foram realizados contatos por telefone e e-mail com as respectivas equipes de gestão por cerca de um mês. Nesse período, das sete áreas protegidas selecionadas houve um retorno de quatro gestores, os quais foram selecionados para a realização de entrevistas semiestruturadas (quadro 11).

\footnotetext{
${ }^{59}$ Os sítios Natura 2000 podem ou não possuir categorias reconhecidas pela IUCN.

${ }^{60}$ World Database on Protected Areas (WDPA)

${ }^{61}$ Disponível em: < https://www.protectedplanet.net/>. Acesso em: Abr 2016.
} 
Quadro 11. Áreas protegidas participantes do estudo (nome, tipos de categorias, órgãos gestores e localização).

\begin{tabular}{|c|c|c|}
\hline $\begin{array}{l}\text { ÁREA PROTEGIDA } \\
\text { URBANA }\end{array}$ & ÓRGÃO GESTOR & LOCALIZAÇÃO \\
\hline \multirow{2}{*}{$\begin{array}{c}\text { Sítio Natura } 2000 \\
\text { Lendspitz-Maiernigg } \\
\text { (LM) }\end{array}$} & $\begin{array}{l}\text { I) Órgão municipal (Departamento de Meio Ambiente de } \\
\text { Klagenfurt); }\end{array}$ & \multirow{2}{*}{$\begin{array}{l}\text { Klagenfurt } \\
\text { (Áustria) }\end{array}$} \\
\hline & $\begin{array}{l}\text { II) Órgão estadual (Conselho Estadual da Rede Natura } \\
\text { 2000) }\end{array}$ & \\
\hline \multirow{3}{*}{$\begin{array}{l}\text { Sítio Natura } 2000 \text { Sonian } \\
\text { Forest }(S F)\end{array}$} & I) Flemish Agency for Nature and Forests (ANB) & \multirow{3}{*}{$\begin{array}{c}\text { Bruxelas, Uccle, Woluwe- } \\
\text { Saint-Pierre, Watermael- } \\
\text { Boitsfort, Auderghem e } \\
\text { Woluwe-Saint-Lambert } \\
\text { (Bélgica) }\end{array}$} \\
\hline & II) Bruxelles Environnement (IBGE) & \\
\hline & III) Direction de la Nature et des Forêts (DNF) & \\
\hline \multirow{6}{*}{$\begin{array}{c}\text { Sítio Natura } 2000 \text { e } \\
\text { Parque Nacional } \\
\text { Zuid-Kennemerland } \\
(\text { PNZK) }\end{array}$} & $\begin{array}{l}\text { I) Órgãos municipais de Velsen, Bloemendaal, Haarlem e } \\
\text { Zandvoort; }\end{array}$ & \multirow{6}{*}{$\begin{array}{l}\text { Haarlem, Zandvoort, } \\
\text { Bloemendaal e Velsen } \\
\text { (Países Baixos) }\end{array}$} \\
\hline & II) Órgão estadual (Província da Holanda do Norte); & \\
\hline & III) Autoridades provinciais de gestão de águas $\left(\mathrm{PWN}^{62}\right)$; & \\
\hline & $\begin{array}{l}\text { IV) Sociedade para Conservação de } \text { Monumentos } \\
\text { Naturais; }\end{array}$ & \\
\hline & $\begin{array}{l}\text { V) Sociedade para a Natureza e Educação Ambiental } \\
\left.\text { (IVN }{ }^{63}\right) \text {; }\end{array}$ & \\
\hline & VI) Comissão Florestal (SBB) & \\
\hline
\end{tabular}

Fonte: Elaborado pela autora (2016).

Os materiais e método do presente capítulo são os mesmos descritos no Capítulo II, utilizados para os casos de estudos nacionais. De maneira geral, após a escolha das áreas protegidas, foram realizadas entrevistas semi-estruturadas pessoalmente com os gestores responsáveis por essas áreas (com exceção do sítio SF que foi realizada via vídeo conferência), bem como um roteiro dirigido para as estrevistas foi elaborado, baseado em questões abordadas pelo Método RAPPAM $^{64}$. Logo, as gestões avaliaram as principais pressões e ameaças de suas áreas protegidas, bem como identificaram as principais ações de conservação voltadas para a sua mitigação.

Todas as entrevistas foram gravadas e posteriormente transcritas de áudio para texto. Além das entrevistas, foram considerados nas análises materiais extras fornecidos pelas gestões (e.g. publicações, planos de manejo, planos de trabalho, folders, entre outros), contribuindo para uma melhor compreensão sobre as questões que envolvem as áreas protegidas participantes. Para a análise de dados, utilizou-se a técnica Análise de Conteúdo.

\footnotetext{
${ }^{62}$ Em holandês: Puur water \& natuur.

${ }^{63}$ Em holandês: Instituut voor natuureducatie em duurzaamheid.

${ }^{64}$ Similarmente ao Capítulo II, não foi objetivo do presente capítulo avaliar a gestão das áreas protegidas participantes, mas sim analisar cada caso de maneira qualitativa e detalhada.
} 


\section{Resultados}

Neste item são apresentados três casos de estudos referentes às áreas protegidas urbanas do continente europeu participantes da presente pesquisa, tais como os sítios Natura 2000 LendspitzMaiernigg (LM), Sonian Forest (SF) e o Parque Nacional Zuid-Kennemerland (PNZK). É importante ressaltar que todas as respostas e informações descritas neste item são resultados das entrevistas e, portanto, são provenientes apenas da opinião da gestão dessas áreas (e.g. gestor e demais membros da equipe). Logo, podem carregar certo grau de subjetividade e incerteza.

De maneira similar ao Capítulo II, para cada caso de estudo, busca-se junto às respectivas gestões, traçar um breve perfil das suas principais características, avaliar as principais pressões dos últimos cinco anos e as futuras ameaças, bem como discutir sobre as ações de conservação adotadas para a mitigação dos seus problemas.

\subsection{Sítio Natura 2000 Lendspitz-Maiernigg (LM)}

O sítio LM (figura 26) possui um território de 77,4 ha, localizada no município de Klagenfurt (Áustria), o maior centro administrativo e econômico do estado da Caríntia. A área foi nomeada para a Rede Natura 2000 no ano de 2005, devido à necessidade em se preservar os seus atributos naturais frente aos projetos de desenvolvimento local que provocariam impactos prejudiciais. De maneira geral, possui grande relevância biológica para o município, por proteger extensas zonas pantanosas na baía oriental do Lago Wörthersee, habitats de relevante interesse comunitário e ameaçados de extinção segundo a Rede Natura 2000.

Nesse sentido, possui como objetivo proteger espécies e habitats ameaçados, sendo gerida pelos órgãos municipal (Departamento de Meio Ambiente de Klagenfurt) e estadual (Conselho Estadual da Rede Natura 2000). O sítio também abrange parte dos territórios de duas paisagens protegidas $^{65}$ (categoria V da IUCN).

\footnotetext{
${ }^{65}$ Protected landscapes Lendspitz-Siebenhügel and Maiernigg.
} 
Figura 26. Imagem de satélite com zoom para o Sítio Natura 2000 Lendspitz-Maiernigg, delineado pela cor laranja.

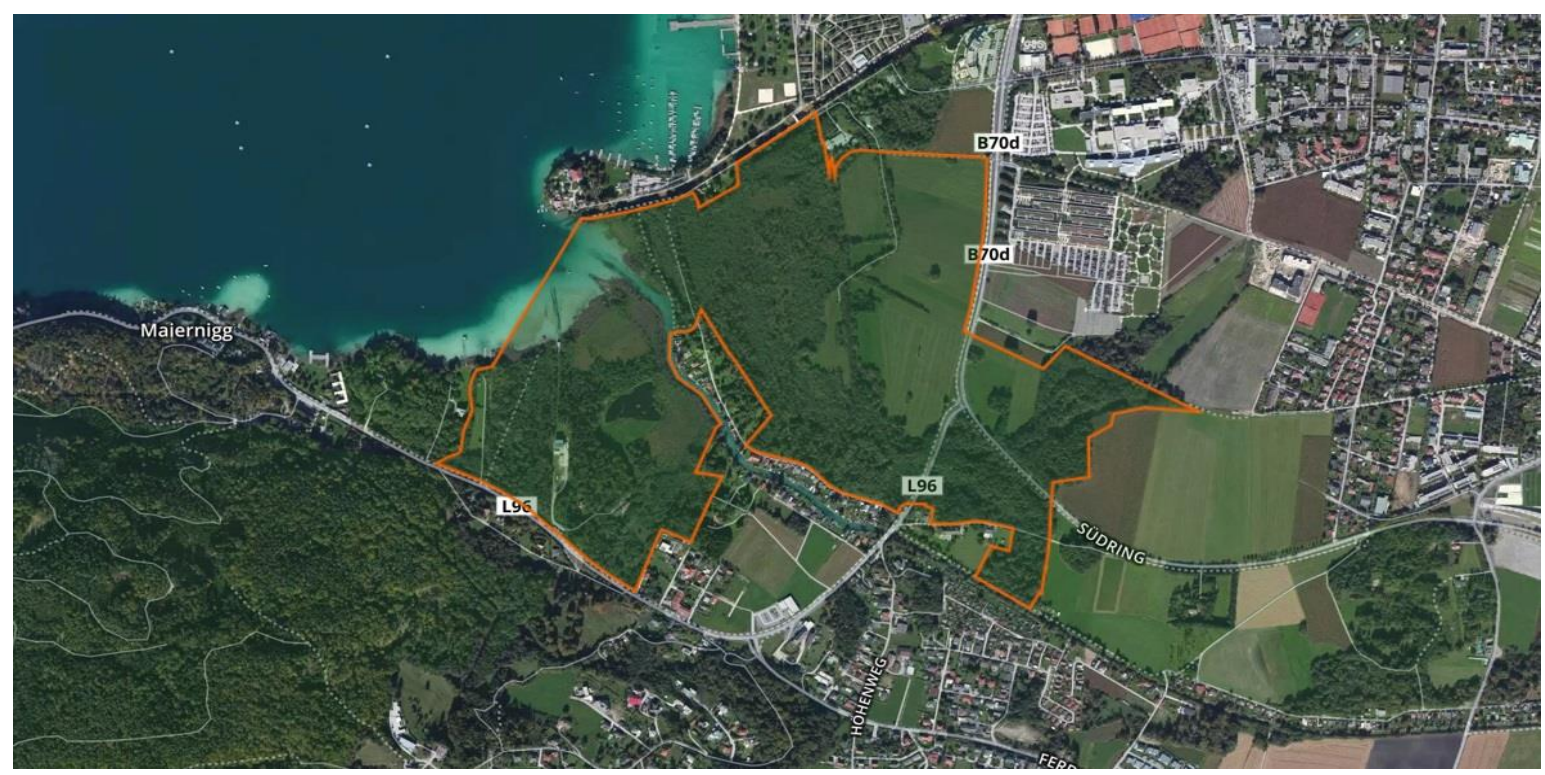

Fonte: IUCN e UNEP-WCMC (2015).

Por estar inserida na malha urbana, LM (figura 27) é vista como uma importante área turística e recreativa, recebendo milhares de visitantes o ano inteiro, principalmente na estação de verão. Localiza-se contígua ao Lago Wörthersee, parque urbano Europark e o museu Minimundus, importantes destinos turísticos do estado da Caríntia. Além disso, encontra-se cercada por uma rodovia (Südring), casas residenciais e de veraneio, instituições de ensino e pesquisa (e.g. Universidade Alpen Adria), centro tecnológico (Lakeside Park), terras agrícolas e um hotel (Seepark Hotel). Desse modo, a gestão alega que os usos do solo no seu entorno ameaçam os seus objetivos de conservação.

Figura 27. Imagem de satélite do Sítio Natura 2000 Lendspitz-Maiernigg (LM), delineado pela cor laranja. A imagem ressalta a sua localização, inserido na malha urbana do município de Klagenfurt.

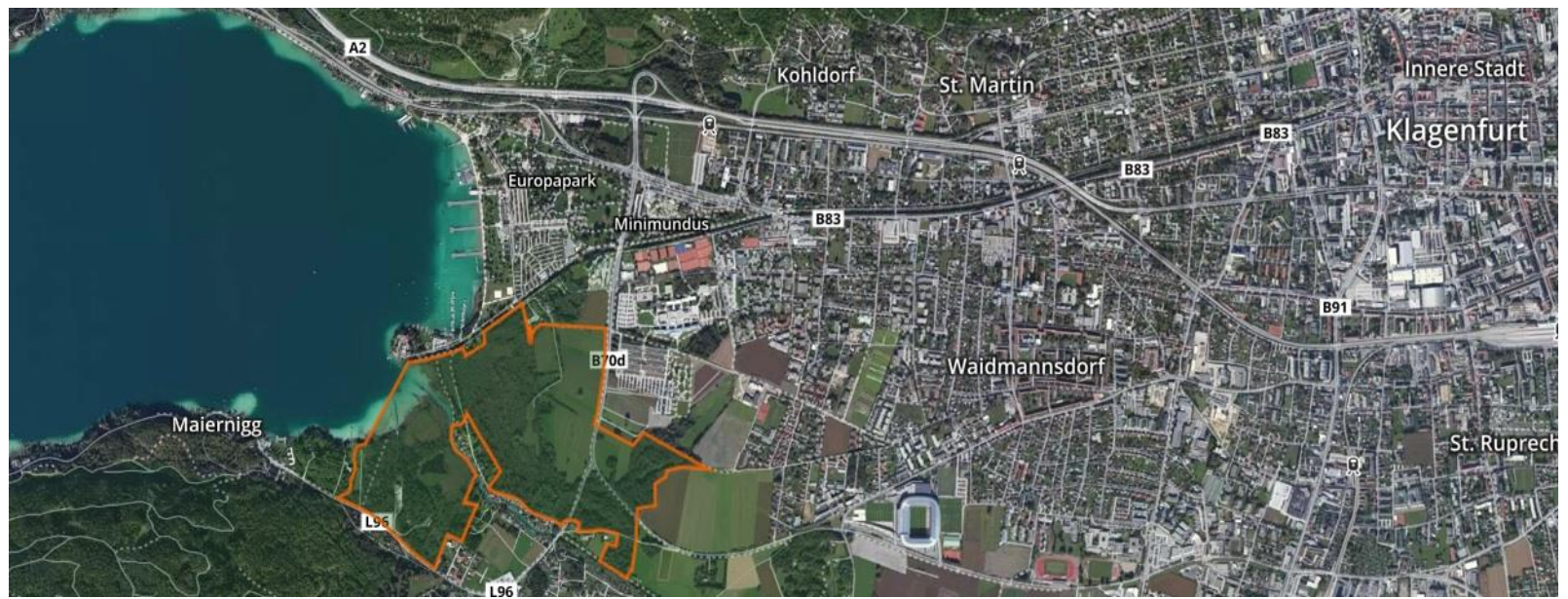

Fonte: IUCN e UNEP-WCMC (2015). 
No que concerne aos amparos legais da área, apesar de sua situação fundiária ser regularizada, a gestão adverte que sua demarcação de fronteiras não é apropriada para atingir os seus objetivos. Segundo a gestão, a área não é claramente delimitada, principalmente nas zonas mais vulneráveis (e.g. nos limites com o Lago), facilitando a ocorrência de atividades ilegais. Além disso, não existe um sistema de zoneamento formalizado no Plano de Manejo, bem como uma zona tampão no seu entorno imediato. Também observa-se que o sítio LM é conectado com uma área protegida contígua ${ }^{66}$.

Em relação ao seu Plano de Manejo, a primeira versão foi realizada em 2007 e revisada mais recentemente em 2015, sendo esta última considerada mais adequada pela gestão por considerar como ums dos principais objetivos à integração com o público, fomentar atividades educativas e pesquisas científicas, bem como por abordar estratégias para uma melhor cooperação entre as instituições responsáveis pela área, tais como os diferentes órgãos municipal e estadual, os quais nem sempre possuem os mesmos interesses.

A participação da sociedade no processo de gestão da área protegida ocorre de diversas maneiras, tais como através das reuniões promovidas pelo Conselho Consultivo e participação nas discussões de políticas ambientais e territoriais que envolvam o sítio. Os Conselhos são formados por membros da sociedade civil (e.g. ONGs, universidades, instituições privadas), políticos, especialistas e membros do Departamento de Meio Ambiente e de Planejamento de Klagenfurt, os quais se reunem periodicamente para discutir o processo de tomada de decisão da área protegida. Também se observa o engajamento do público no desenvolvimento de projetos e atividades educativas, os quais contam com a participação de grupos de apoio e voluntários.

Para a divulgação das principais informações, noticias, eventos e atividades relacionadas ao sítio, utiliza-se os veículos de mídia local (jornais, rádio e TV) e mídias sociais. Dentre os principais parceiros, destaca-se a Universidade Alpen Adria, responsável por desenvolver disciplinas e atividades com os estudantes, utilizando o sítio como plataforma de pesquisas e aulas práticas sobre assuntos relacionados à conservação da natureza em geral.

No âmbito da Rede Natura 2000, cada Estado-membro é responsável por formar um Conselho Estadual da rede, responsável por orientar e administrar sobre os projetos que serão implementados nas áreas protegidas designadas em seu território. Para o caso do Estado da Caríntia (onde o sítio LM está inserido), este é composto por membros de órgãos estaduais e municipais,

\footnotetext{
${ }^{66}$ Protected landscape Schrottkogel.
} 
sociedade civil, especialistas acadêmicos, ONGs relacionadas à conservação da natureza, líderes políticos, entre outros.

Em relação aos recursos humanos do sítio LM, verifica-se a inexistência de funcionários exclusivos para auxiliar na gestão. Todos os funcionários são contratados pelos órgãos da administração municipal e estadual para executar projetos específicos, previamente aprovados no Conselho. Logo, a área carece de vigilantes para as atividades de fiscalização e monitoramento.

Por fim, a área protegida é financiada pelo município e pela administração estadual competente, bem como recebe recursos financeiros esporádicos referentes à compensações ambientais e instituições privadas. Desse modo, a gestão adverte que os recursos financeiros dos últimos cinco anos têm sido adequados para conduzir as atividades críticas de gestão. Além disso, existem possibilidades de contratos de concessões para a área. Contudo, não há um orçamento anual, apenas orçamentos referentes aos projetos a serem implementados. Logo, não há previsão financeira estável a longo prazo. Ainda, todos os projetos a serem executados necessitam passar pela aprovação do Conselho, onde, segundo a gestão, há um longo processo para a solicitação de recursos.

\subsubsection{Pressões e Ameaças ${ }^{67}$}

As principais pressões e ameaças do sítio LM são avaliadas pela sua gestão e discutidas conforme o seu grau de intensidade (figura 28).

\footnotetext{
${ }^{67}$ Apêndice VII.
} 
Figura 28. Principais pressões e ameaças do Sítio Natura 2000 Lendspitz-Maiernigg (LM). As pressões e ameaças avaliadas como severas possuem pontuação entre 25 a 64, as altas possuem pontuação entre 10 a 24 pontos, as moderadas entre 4 a 9 pontos, e por fim, as leves possuem de 1 a 3 pontos.

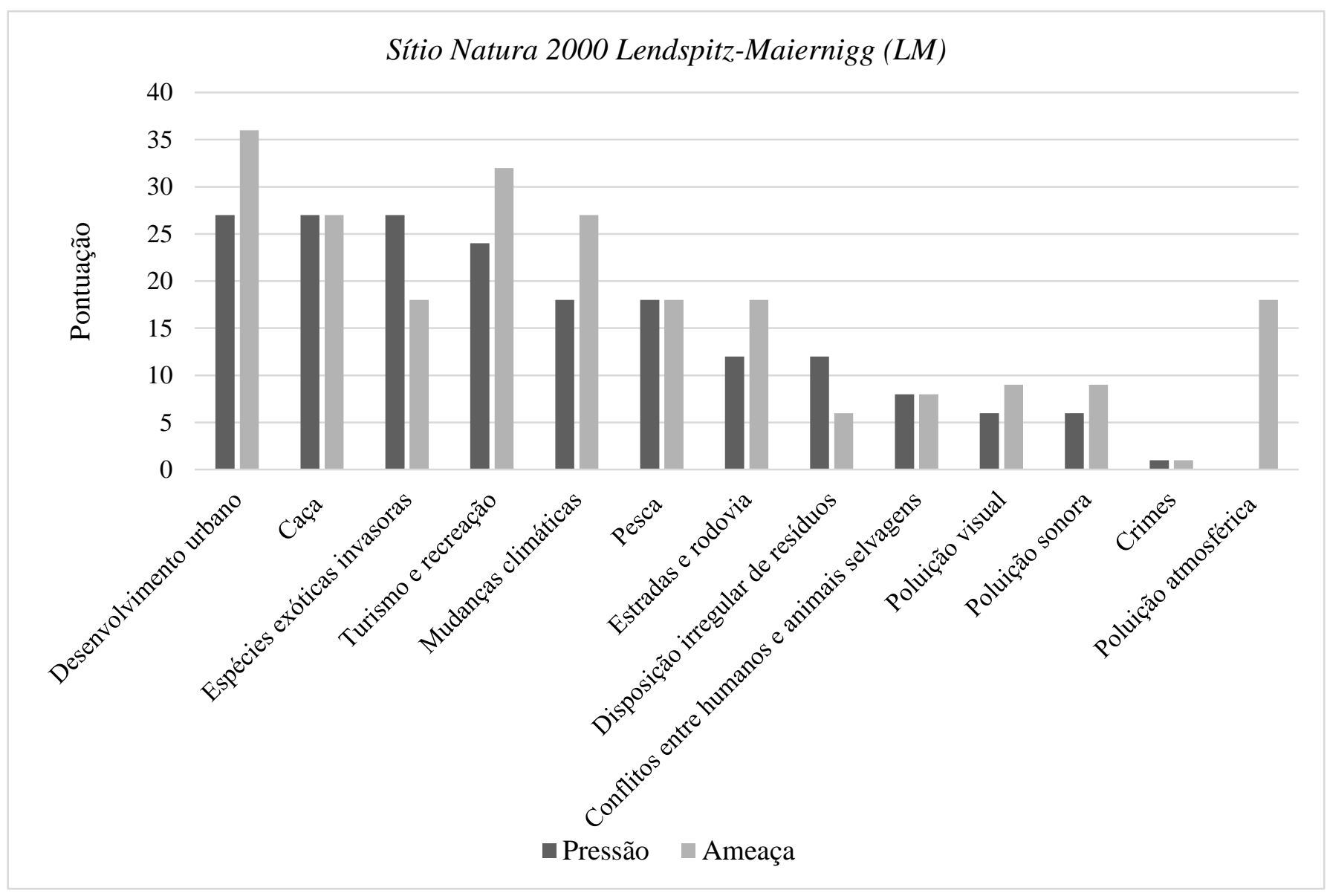

Fonte: Elaborado pela autora (2016), a partir das informações fornecidas pela gestão.

\section{Pressões severas:}

Avaliam-se três tipos de pressões severas (pontuação de 25 a 64) ao sítio LM: o desenvolvimento urbano do entorno (27 pontos), o qual aumentou drasticamente nos últimos cinco anos; o estabelecimento de espécies exóticas invasoras, as quais aumentaram ligeiramente e as atividades de caça no interior da área protegida (27 pontos), que permaneceu constante nos últimos anos.

O sítio LM está inserido na malha urbana, cercado por diversas habitações, comércios, serviços e vias expressas no seu entorno imediato. Segundo a gestão, essa pressão se intensificará nos próximos anos (atingindo 36 pontos), visto os novos projetos de expansão de empreendimentos na região (tais como a expansão do Parque Tecnológico de Lakeside, na fronteira nordeste da área protegida). As residências do entorno, que no passado eram apenas poucas casas de veraneio, 
atualmente aumentaram em número e tamanho, tornando-se casas residenciais permanentes. Esses proprietários utilizam os caminhos do interior da área protegida para chegar até o Lago, local de intensa visitação turística. Além disso, também construiram cercas em suas casas, bloqueando passagens e prejudicando a dispersão de espécies de cervídeos. Logo, houve o aumento da especulação imobiliária com a valorização da região, devido principalmente aos seus atributos turísticos.

Outra pressão severa à área protegida é a caça no seu interior. Segundo as normas estabelecidas pelo Estado da Caríntia, a caça é permitida em locais e épocas determinadas, para certas espécies e em quantidade limitada. Para as atividades de caça no interior da área protegida, verifica-se que os caçadores realizam a caça desportiva, atividade tradicional da cultura local, não sendo um instrumento de conservação para controles populacionais de determinadas espécies. Apesar de ser uma área protegida, a caça é permitida para determinadas espécies que não se encontram nas listas de proteção da Rede Natura 2000, apenas para os indivíduos que possuem licença, seguindo as diretrizes estabelecidas pelo país e pela Associação de Caçadores da Província da Carintia ${ }^{68}$.

Desse modo, apesar dos caçadores possuirem direitos legais, tais atividades ocorrem geralmente no período noturno, havendo relatos de caçadores que atiram em espécies protegidas, não havendo nenhuma fiscalização. Além disso, eles perturbam as espécies e habitats quando adentram na área (e.g. compactação do solo, abertura de trilhas ilegais, disposição irregular de resíduos no local, entre outros). Assim, a gestão alega que essa pressão continuará a ocorrer nos próximos anos, pelo fato do município concordar com tal atividade e obter receita com a emissão de licenças desses indíviduos.

Mais uma pressão severa à área protegida é a presença de espécies exóticas invasoras, destacando-se as espécies de flora: Solidago virgaurea L., Impatiens glandulifera e Fallopia japonica. De maneira geral, apesar de ser um problema que necessita de manejo e financiamento permanente, a gestão espera uma diminuição em seu grau de intensidade para os próximos anos, devido as diversas ações de manejo que vêm sendo adotadas.

${ }^{68}$ Em austríaco: Kärntner Jägerschaft. Disponível em: < http://www.kaerntner-jaegerschaft.at/>. Acesso em: Out 2016. 


\section{Pressões altas:}

As pressões avaliadas com alto grau de intensidade (pontuação de 10 a 24) e que aumentaram ligeiramente nos últimos cinco anos são: mudanças climáticas (18 pontos), pesca (18 pontos), estradas e rodovias (12 pontos) e disposição irregular de resíduos (12 pontos). Além disso, as atividades relacionadas ao turismo e recreação também são consideradas altas pressões (24 pontos), contudo, aumentaram de maneira mais drástica nos últimos cinco anos.

Conforme mencionado anteriormente, Lendspitz-Maiernigg é uma importante área turística e recreativa para os moradores da cidade. O público local busca por lazer, realizando caminhadas, passeios com a familía e animais domésticos, ciclismos, natação, piqueniques e uso de veículos aquáticos (e.g. barcos elétricos e jet skis). A cidade de Klagenfurt também realiza todos os anos alguns eventos nas proximidades da área protegida (eventos esportivos, festas e concertos) no Lago Wörthersee, atraindo milhares de pessoas. Desse modo, turismo e recreação são uma pressão alta para o local, onde verifica-se que grande parte dos visitantes que a utilizam não possuem conhecimento de que se trata de um sítio Natura 2000, bem como não sabem sobre os seus objetivos primordiais de conservação.

As mudanças climáticas também são consideradas altas pressões e, segundo a gestão, nas estações mais quentes, observam-se crescentes alterações nas características físicas (altura e volume) do solo. Como resultado, a área seca muito rapidamente e já afetam prejudicialmente algumas espécies de anfíbios. Contudo, não existem atualmente pesquisas científicas sendo realizadas sobre essa questão.

Outra pressão avaliada como alta é a ocorrência de atividades de pesca no interior da área protegida. De maneira geral, existe uma Associação de Pescadores do Estado da Carintia ${ }^{69}$, responsável por estabelecer as diretrizes para a execução de tal atividade. Para o sítio LM, verificase a pesca desportiva de espécies não listadas na Rede Natura 2000. Ademais, o município incentiva a utilização do local por ser a única área público no entorno do Lago Wörthersee, cercado por propriedades privadas.

Similarmente às atividades de caça, os pescadores adentram a área protegida no período noturno, perturando as espécies e habitats (através de aberturas de trilhas ilegais, promoção de ruídos, luzes e disposição irregular de resíduos). Além disso, não há uma fiscalização e um controle

${ }^{69}$ Em austríaco: Kärntner Fischereivereinigung. Disponível em: 〈http://www.kaerntner-fischerei.at/>. Acesso em: Abr 2016. 
da gestão da área sob tal atividade, onde não se sabe se há a pesca de espécies proibidas. Logo, segundo a opinião da gestão, tais atividades continuarão a ocorrer, por serem lucrativas para o município, o qual recebe recursos para a emissão de licenças para os pescadores.

A presença de estradas e uma rodovia (Südring) no entorno da área protegida, configuramse como pressões de algo grau, a qual chega a receber mais de 20.000 carros por o dia na temporada de verão. Como resultado, observa-se a fragmentação da área e a ocorrência de atropelamentos de espécies, em maior frequencia com anfíbios, bem como a existem ruídos e perturbações causados pelo tráfego. Ademais, não é esperado para os próximos cinco anos o estabelecimento de novas infraestruturas lineares, no entanto, espera-se um aumento do grau dessa pressão, em decorrência do aumento de fluxo de veículos. Nesse sentido, a gestão alega que não há monitoramento climático sendo realizado para dizer se a poluição atmosférica emitida pelos veículos que utilizam as vias esteja trazendo impactos prejudiciais à área, mas é considerada pela gestão como uma futura ameaça de alto grau (18 pontos), devido ao aumento das emissões de gases poluentes para os próximos anos.

Por fim, a disposição irregular de resíduos também é uma pressão alta. Por ser uma área de lazer e visitação intensa, a produção de resíduos pelos visitantes é diária, especialmente nas estações mais frequentadas. Logo, o município é encarregado de recolher as lixeiras, mas não o fazem com a frequencia necessária. Como resultado, estão sempre cheias, sendo um problema sério para o local. No entanto, a gestão espera que nos próximos anos essa pressão diminua de intensidade (atingindo 6 pontos), devido a uma série de medidas mitigadoras para esse problema ${ }^{70}$.

\section{Pressões moderadas:}

As pressões avaliadas pela gestão como moderadas (pontuação de 4 a 9) e que permaneceram constantes nos últimos cinco anos são: poluição visual e sonora (ambas com 6 pontos). Ademais, os conflitos entre humanos e animais selvagens (8 pontos) também são pressões moderadas, mas aumentaram ligeiramente nos últimos cinco anos.

A poluição sonora ocorre devido à emissão de ruídos ocasionados no tráfego de vias de acesso, residências e eventos de lazer que ocorrem na temporada de verão na área do entorno, os quais trazem perturbações. De maneira similar, a poluição visual ocorre devido às diversas fontes luminosas artificiais do entorno, expostas no período noturno.

\footnotetext{
${ }^{70}$ Ações detalhadamente descritas no item "ações de conservação".
} 
Outras pressões moderadas são os conflitos entre humanos e animais selvagens. Estes aumentaram drasticamente nos últimos anos, visto as frequentes ocorrências de atropelamentos de algumas espécies de répteis e anfíbios. Além disso, se deve ao reaparecimento de castores na região, espécie que contrói barragens e se alimenta de árvores dos moradores do entorno. Desse modo, os castores vêm trazendo danos para as residências dos moradores, os quais não sabem lidar com o problema. Logo, a gestão acredita que esse conflito continuará a ocorrer nos próximos anos, devido a reincidência da espécie na região.

\section{Pressões leves:}

Das pressões avaliadas com suave grau de intensidade, observa-se apenas o uso de substâncias ilícitas dentro da área protegida, atividade realizada por grupos de jovens que adentram a área protegida no período noturno, e que provavelmente permanecerão a ocorrer nos próximos anos.

Em suma, foram identificadas 13 tipos de pressões e ameaças na área protegida. Desse total, a gestão avaliou que 7 irão aumentar em algum nível de intensidade para os próximos cinco anos. Logo, a gestão adverte que a principal causa para esse aumento se deve ao processo de desenvolvimento urbano na região, o qual vem implicando na multiplicação de impactos ambientais, decorrentes da proximidade dos assentamentos humanos sobre a área de influência do sítio LM.

\subsection{Sítio Natura 2000 Sonian Forest ${ }^{71}$ (SF)}

O município de Bruxelas, maior área urbana da Bélgica, possui diversas áreas protegidas pertencentes a Rede Natura 2000, correspondendo a 14\% de seu território. A sua maior parcela está representada pela Sonian Forest (sendo incluída na Rede no ano de 2004) e demais áreas arborizadas do seu entorno, totalizando 2.071 ha. Logo, esta área protegida foi escolhida como caso de estudo da presente pesquisa por ser a parcela mais representativa.

De maneira geral, o sítio SF (figura 29) é uma área protegida constituída de cinco reservas naturais (Verdronken Kinderen, Rouge-Cloître, Vuilbeek, Dry-Borren e Pinnebeek) e três reservas florestais (Rouge-Cloître Abbey, Joseph Zwaenepoel e Gripensdelle), as quais possuem objetivos

\footnotetext{
${ }^{71}$ Nota-se que a área protegida é conhecida em quatro línguas diferentes: Forêt de Soignes (francês), Zoniënwoud (holandês e alemão) e Sonian Forest. Desse modo, opta-se pelo termo em inglês, por ser a língua internacionalmente mais conhecida.
} 
de conservação distintos. Apesar da maior parte estar inserida na cidade de Bruxelas, a área também abrange os seguintes municípios: Uccle, Woluwe-Saint-Pierre, Watermael-Boitsfort, Auderghem e Woluwe-Saint-Lambert.

Nesse contexto, a área encontra-se inserida em uma malha densamente urbana, entre três regiões: a Região Flamenga (56\%), a Região da Valônia (6\%) e a Região de Bruxelas (38\%) e é gerida por três agências distintas: Flemish Agency for Nature and Forests (ANB), Bruxelles Environnement (IBGE) e Direction de la Nature et des Forêts (DNF). Apesar de possuírem línguas e culturas diferentes, as três regiões trabalham juntos na mesma base legislativa e filosofia de conservação.

Figura 29. Imagem de satélite do Sítio Natura 2000 Sonian Forest, delineado pela cor laranja. A imagem ressalta a sua localização, inserido na malha urbana da região de Bruxelas (Bélgica).

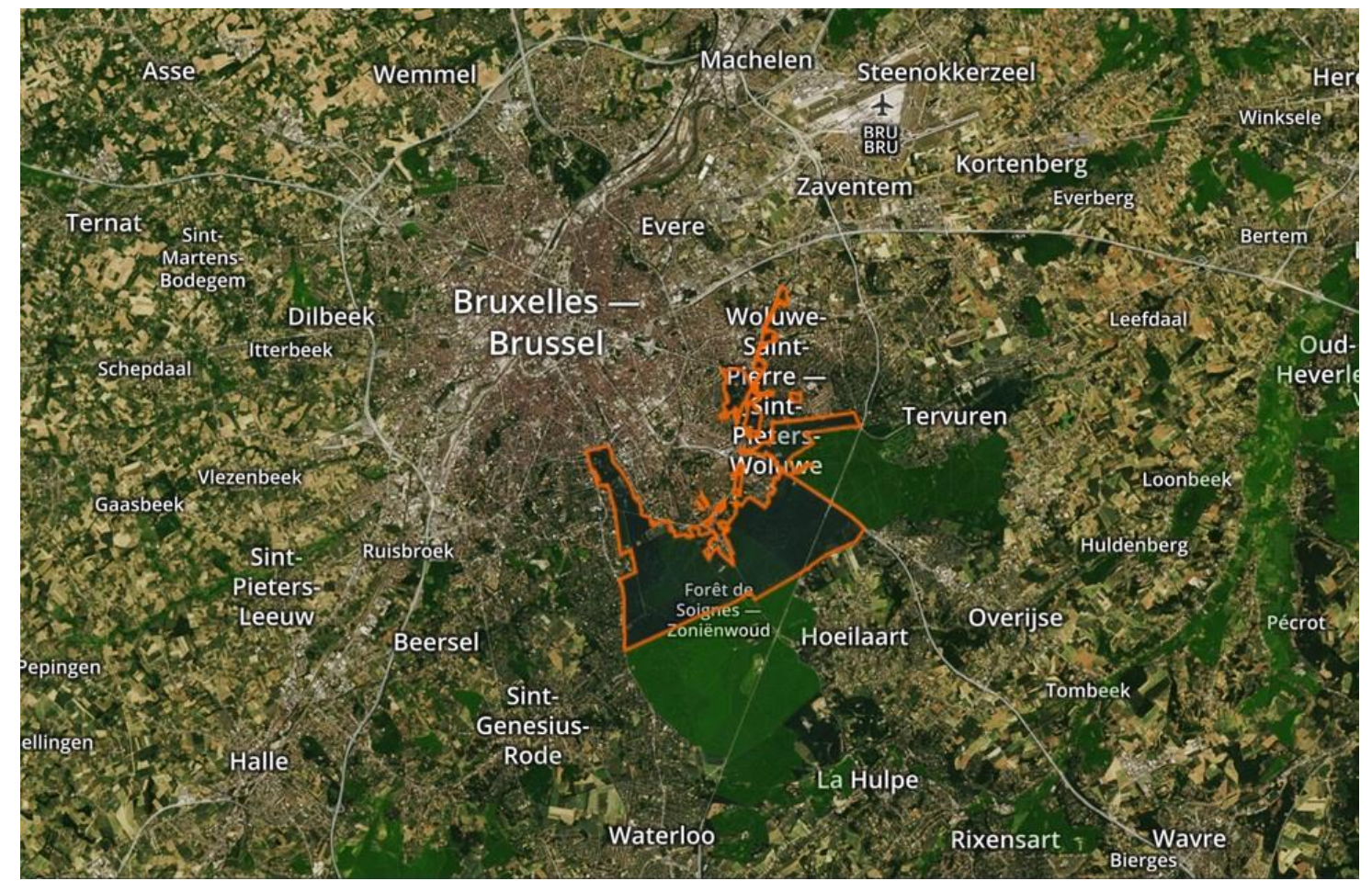

Fonte: IUCN e UNEP-WCMC (2015).

Atualmente, o sítio SF é conhecido como o "pulmão verde" de Bruxelas, representando 60\% das áreas verdes públicas da cidade, possuindo grande relevância biológica para a região. Ela também possui importância socioeconômica, cultural e histórica, o local é datado em mais de 10.000 anos com diversas edificações históricas em seu território (e.g. mosteiros, túmulos, acampamentos pré-históricos e castelos centenários), descobertas por escavações arqueológicas. Além disso, observa-se que grande parte da área é composta por espécies de faia-europeia (Fagus 
sylvatica L.), que permanecem preservadas por mais de duzentos anos, indicadas como Patrimônio Mundial pela UNESCO. Contudo, ao longo do tempo, a área protegida vem sofrendo com o desenvolvimento das cidades e expansão da agricultura.

Durante o processo de planejamento do sítio SF, foram desenvolvidos cinco objetivos primordiais que constituíram a base da sua gestão: I) aumentar a biodiversidade e proteção das zonas mais vulneráveis; II) melhorar a infra-estrutura recreativa e turística para os visitantes; III) promover o aumento das áreas verdes no entorno; IV) reduzir os efeitos da fragmentação de habitats e V) criar uma única identidade para a área protegida, diminuindo as abordagens distintas de cada região.

Em relação às estratégias de comunicação e divulgação, as gestões almejam por uma identidade corporativa forte e reconhecível pelo público. Para tanto, foi planejada e implementada desde 2010 uma estratégia de comunicação conjunta entre as três gestões. Várias ações vêm sendo executadas, como a criação de folders e cartilhas de informações (atualizada todos os anos), um website oficial interativo, revistas eletrônicas bianuais e boletins eletrônicos, todos produzidos em quatro línguas (inglês, francês, holandês e alemão). Segundo a gestão, as estratégias de comunicação têm sido bem sucedidas ${ }^{72}$, onde os visitantes podem encontrar todas as informações importantes em fáceis plataformas informativas e ilustrativas. Além disso, todos os eventos, atividades e cursos são promovidos nesses veículos.

Em relação aos recursos humanos, a gestão alega que o número de funcionários não é suficiente para gerir de maneira adequada a área protegida. No entanto, ela adverte que eles possuem competências adequadas para conduzir atividades críticas de gestão e possuem capacitação periódica. Além disso, a área possui diversos parceiros (instituições privadas e organizações da sociedade civil $^{73}$ ), formando um grande grupo de voluntarios que auxiliam em diversas ações na área protegida (e.g. condução de visitantes, promoção de campanhas educativas, ações de manejo diversas, etc.). Ela também possui um Conselho Consultivo formado por membros

\footnotetext{
${ }^{72}$ De acordo com a gestão, os primeiros resultados desta estratégia de comunicação estão começando a aparecer. Em 2015, a área protegida ganhou reconhecimento internacional ao acolher o Fórum Europeu sobre Florestas Urbanas (EFUF), importante conferência internacional que procurou discutir questões relacionadas às áreas naturais em ambientes urbanos.

${ }^{73}$ Verificam-se mais de 15 associações parceiras, tais como: Natura Sonian, Nature Guides of Brussels e Friends of the Sonian Forest. Disponível em: < http://www.sonianforest.be/lend-a-hand/join-an-association/>. Acesso em Abr 2016.
} 
da sociedade civil, especialistas florestais e administrativos, os quais supervisionam conjuntamente as atividades e se reúnem periodicamente.

Por fim, o sítio SF recebe recursos financeiros dos governos municipais e estadual, bem como por associações do setor público e privado, que buscam promover a conservação do meio ambiente. Além disso, existem parceiros financeiros do setor privado responsáveis pela gestão sustentável da produção de madeira, nas reservas florestais ${ }^{74}$. Apesar das diversas fontes de financiamento, a gestão alega que não há perspectivas financeiras estáveis a longo prazo para a área protegida.

\subsubsection{Pressões e Ameaças ${ }^{75}$}

A gestão da SF avaliou as principais pressões e ameaças para a área protegida, segundo um grau de intensidade (figura 30).

Figura 30. Principais pressões e ameaças do Sítio Natura 2000 Sonian Forest (SF). As pressões e ameaças avaliadas como severas possuem pontuação entre 25 a 64, as altas possuem pontuação entre 10 a 24 pontos, as moderadas entre 4 a 9 pontos, e por fim, as leves possuem de 1 a 3 pontos.

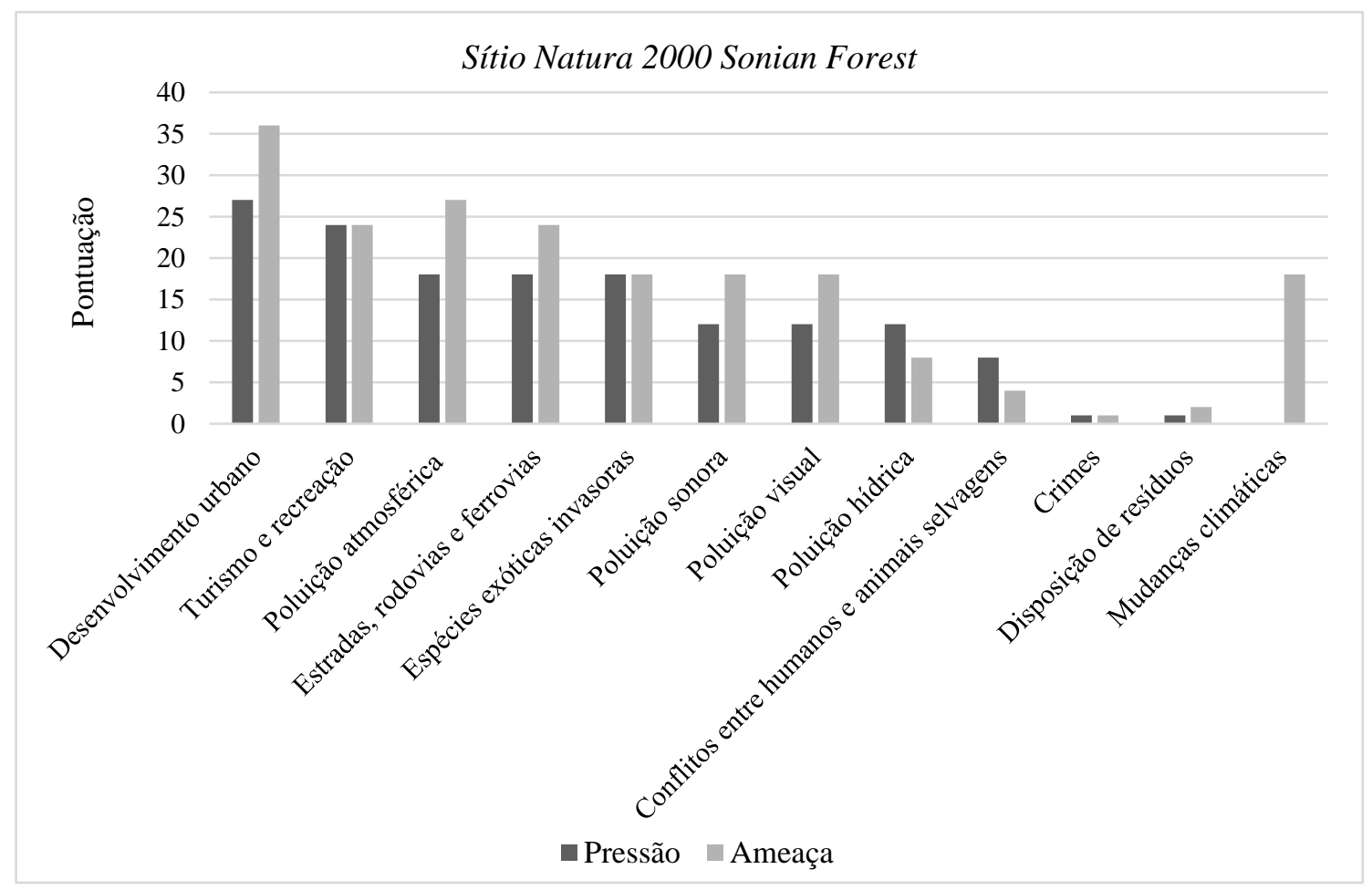

Fonte: Elaborado pela autora (2016), a partir das informações fornecidas pela gestão.

${ }^{74}$ A madeira da Sonian Forest é reconhecida com o certificado de silvicultura sustentável, fornecido pelo Forest Stewardship Council (FSC) e pelo Programme for the Endorsement of Forest Certification Schemes (PEFC).

${ }^{75}$ Apêndice VIII. 


\section{Pressões severas:}

Segundo a avaliação da gestão, as pressões severas (pontuação de 25 a 64) que aumentaram drasticamente nos últimos cinco anos são: desenvolvimento urbano (27 pontos) e turismo e recreação (24 pontos).

Verifica-se que a área protegida está cercada por diversas habitações, vias de acesso, comércios, entre outros estabelecimentos, localizada a menos de $10 \mathrm{~km}$ da cidade de Bruxelas. Logo, espera-se um aumento considerável de empreendimentos no seu entorno, bem como um aumento no fluxo de pessoas e veículos, sendo uma ameaça severa (36 pontos) à área.

Em relação às atividades turísticas e recreativas, ressalta-se que a área protegida recebe pelo menos dois milhões de visitas por ano. Inevitavelmente, a gestão adverte que a visitação traz impactos prejudiciais à área, como abertura de novas trilhas por ciclistas e corredores, perturbação da vida selvagem, ruídos, entre outros. Dentre as atividades mais procuradas pelo público, destacam-se: atividades de caminhada, ciclismo, pesca, passeios a cavalo, visitas aos centros de exposições e monumentos históricos, entre outros.

\section{Pressões altas:}

As pressões avaliadas com alto grau de intensidade (pontuação de 10 a 24) e que aumentaram ligeiramente nos últimos cinco anos são: poluição atmosférica (18 pontos); estradas, rodovias e ferrovias (18 pontos); espécies exóticas invasoras (18 pontos); poluição sonora (12 pontos) e poluição visual (12 pontos). Além disso, a poluição hídrica (12 pontos) também é avaliada como uma alta pressão, mas esta vem diminuindo ligeiramente nos últimos cinco anos.

Em relação às infraestruturas lineares, verificam-se diversas estradas (e.g. La Hulpe, Dubois, Tervuren), ferrovias (entre Bruxelas e Luxemburgo) e rodovias (RO/E411 e L161) que a atravessam e estão no seu entorno imediato, trazendo inúmeros impactos para as espécies e habitas (e.g. contribuem para a degradação local, ocorrências de atropelamentos e prejuizos na migração anual de algumas espécies de anfíbios). Além disso, verifica-se para os próximos anos um projeto de duplicação das ferrovias, bem como um aumento considerável do fluxo de cargas e veículos motorizados. Nesse sentido, a poluição atmosférica também é avaliada como uma alta pressão à área pela gestão, sendo esta proveniente do tráfego de veículos motorizados nessas vias.

No que concerne as espécies exóticas invasoras observadas na área protegida, destacam-se as espécies de flora: Prunus serotina, Impatiens parviflora e Fallopia japonica e de fauna: Branta canadenses e Alopochen aegyptiacus. Estas espécies vêm se dispersando rapidamente e 
continuarão como altas ameaças (18 pontos) para a área nos próximos cinco anos, necessitando serem controladas permanentemente.

A poluição sonora também é uma alta pressão e resulta da emissão de ruídos prejudiciais às espécies do sítio $\mathrm{SF}$, devido a proximidade como o desenvolvimento urbano. Logo, por estar totalmente inserida na malha urbana, a área recebe ruídos de todos os lados, como por exemplo dos sobrevôos de aeronaves (a área encontra-se na rota de vôos do Aeroporto de Bruxelas), tráfego de carros nas vias de acesso próximas e que adentram a área protegida, ruídos de construções, assentamentos humanos, entre outros. Similarmente, a área protegida também vêm sendo impactada pela poluição visual do entorno, a qual também ocorre devido a proximidade com o desenvolvimento urbano e é provocada pelo aumento da incidência de luzes noturnas nos arredores da área protegida. A gestão alega que é alta a probabilidade de ambas as pressões continuarem nos próximos anos com um maior grau de intensidade (18 pontos).

Em relação a poluição hídrica, ela ocorre devido ao uso intensivo das estradas, rodovias, e ferrovias, onde verifica-se o transporte de produtos químicos e substâncias tóxicas, os quais são carreados pelas águas da chuvas, contaminando os corpos d'água próximos à essas vias de acesso. Além disso, a empresa ferroviária utiliza por vezes pesticidas, que também podem ser carreados para os corpos d'água. Também se observa no inverno a poluição salina, uma vez que grandes quantidades de sal são utilizadas para derreter o gelo nas estradas. Por fim, também verifica-se a contaminação dos corpos d'água pelos assentamentos humanos nos arredores, os quais despejam de maneira ilegal seus efluentes.

\section{Pressões moderadas:}

Os atropelamentos de espécies da fauna silvestre são conflitos entre humanos e animais selvagens (8 pontos). Isso ocorre pelo estabelecimento de infraestruturas lineares na região, bem como devido ao aumento do fluxo de veículos. Devido a uma série de ações ${ }^{76}$ visando a conexão de áreas fragmentadas com os arredores, a gestão espera que essas ocorrências tenderão a diminuir nos próximos anos (4 pontos).

\footnotetext{
${ }^{76}$ Ações detalhadamente descritas no item "ações de conservação".
} 


\section{Pressões leves:}

As pressões avaliadas como leves são: crimes (1 ponto) e disposição irregular de resíduos (1 ponto), as quais permaneceram constantes nos últimos cinco anos. Desse modo, a gestão adverte que por ser uma área protegida urbana, ela muitas vezes é vista como um local ideal para a realização de crimes, devido a sua localização e possivelmente por ser um lugar fácil de se esconder. Dentre os crimes mais comuns observados, destacam-se atos suicidas, uso e tráfico de drogas, ocorrendo em baixa frequência. Eles são considerados como pressões leves, no que se refere à segurança do local para os visitantes, e provavelmente devido a imprevisibilidade de tais atividades, continuarão a ocorrer nos próximos cinco anos como ameaças leves (1 ponto).

Outra pressão avaliada como leve é a disposição irregular de resíduos. De maneira geral, observam-se resíduos (e.g. embalagens em geral, restos de alimentos, etc.) gerados pelos visitantes, os quais muitas vezes não os acondicionam adequadamente, gerando alguns impactos localizados. Além desses resíduos localizados no interior da área, verifica-se regularmente a disposição de resíduos da construção civil e materiais de poda nas áreas límitrofes. Segundo a gestão, devido a cobrança pela coleta de resíduos instituída no país, muitos indivíduos dispõem seus resíduos durante o período noturno na SF (isto é, uma área pública), isentando-se de taxas. Contudo, dada a dimensão da área protegida, tais atividades são localizadas e de baixo impacto, consideradas pela gestão como ameaças leves (2 pontos).

\section{Ameaças:}

Observa-se que a gestão não considera que as mudanças climáticas estejam trazendo impactos prejudicias à Sonian Forest atualmente, mas são identificadas como futuras ameaças à área (18 pontos). Segundo a gestão, pesquisas científicas realizadas no local indicam que as mudanças climáticas representam uma grande ameaça para a área, devido grande parte ser composta por espécies de faia-europeia (Fagus sylvatica L.), tornando-a mais vulnerável para as futuras mudanças no clima. Este tipo de vegetação é sensível a climas mais quentes e secos e estas condições são esperadas para os próximos anos, segundo modelos climáticos realizados para a região, sendo uma grande preocupação para os gestores.

Por fim, verificam-se 12 tipos de pressões e ameaças para a área protegida SF. Do total, 7 irão aumentar em algum nível de intensidade nos próximos cinco anos. Similarmente às demais áreas protegidas do presente estudo, a gestão alega que a principal causa se deve à expansão urbana 
e ao aumento dos fluxos de pessoas e veículos nas proximidades, trazendo impactos prejudiciais à área protegida.

\subsection{Sítio Natura 2000 e Parque Nacional Zuid-Kennemerland (PNZK)}

O PNZK (figura 31) possui uma área de 3.800 ha e abrange os municípios de Haarlem, Zandvoort, Bloemendaal e Velsen, localizado a cerca de $20 \mathrm{~km}$ de Amsterdã, capital e cidade mais populosa dos Países Baixos (figura 32).

Figura 31. Imagem de satélite com zoom do Sítio Natura 2000 e Parque Nacional Zuid-Kennemerland (PNZK), delineado pela cor laranja.

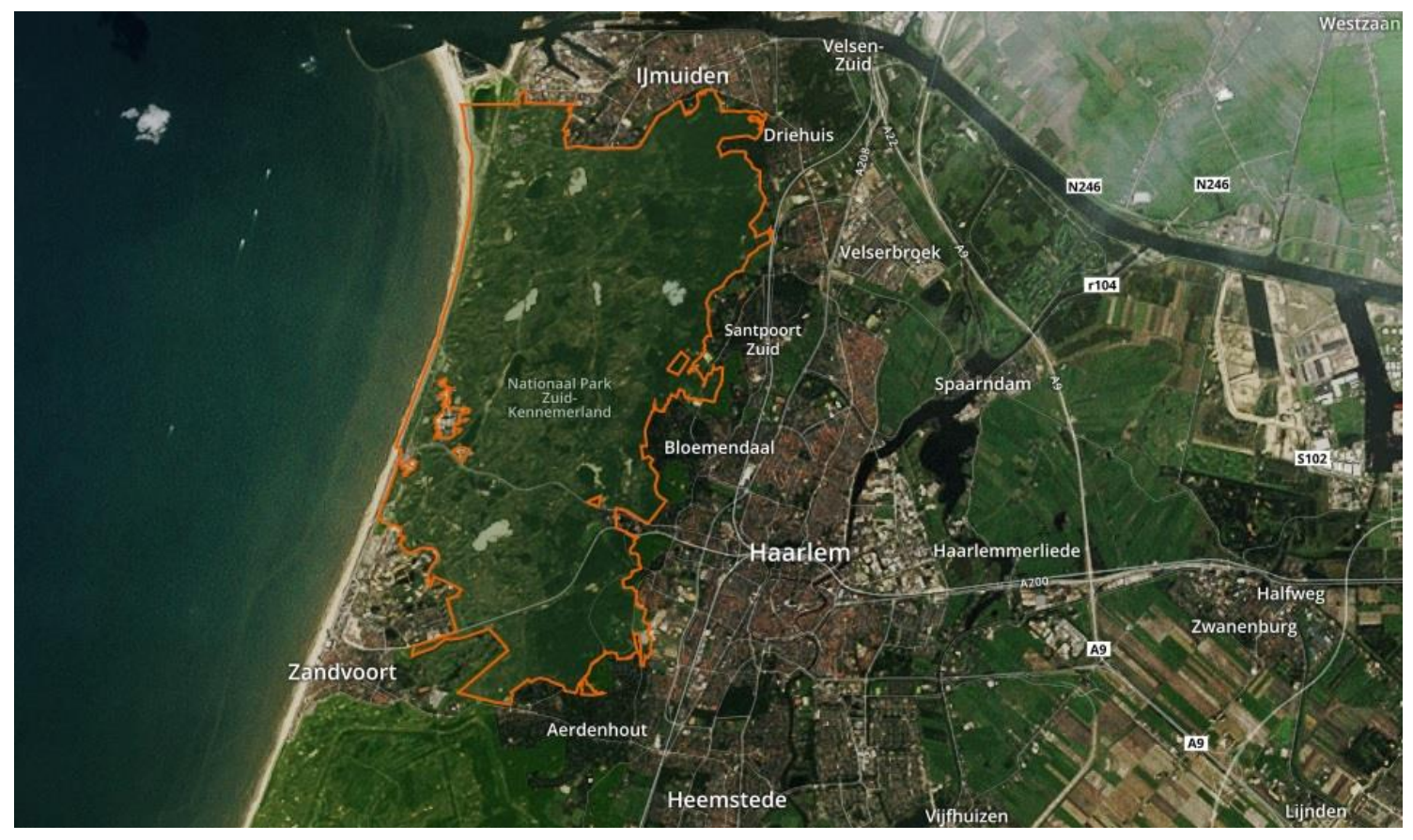

Fonte: IUCN e UNEP-WCMC (2015).

O Parque tem como objetivo principal proteger a biodiversidade e os processos ecológicos do seu território, bem como promover a educação, pesquisas científicas e turismo e recreação. Ele foi estabelecido oficialmente em 1995 e faz parte do Sistema de Parques Nacionais do país, a cargo do Ministério da Agricultura da Holanda. Pertence a categoria II da IUCN e à Rede Natura 2000.

De maneira geral, o Parque apresenta um modelo misto de gestão, com entidades públicas e privadas à sua frente, tais como os órgãos municipais (Velsen, Bloemendaal, Haarlem e Zandvoort) e estadual (Província da Holanda do Norte), autoridades provinciais de águas (PWN), 
Sociedade para Conservação de Monumentos Naturais, Sociedade para a Natureza e Educação Ambiental (IVN), Comissão Florestal (SBB) e proprietários privados.

Figura 32. Imagem de satélite do Sítio Natura 2000 e Parque Nacional Zuid-Kennemerland (PNZK), delineado pela cor laranja. A imagem ressalta a sua localização, recebendo influências diretas da malha urbana da região de Amsterdã (Países Baixos).

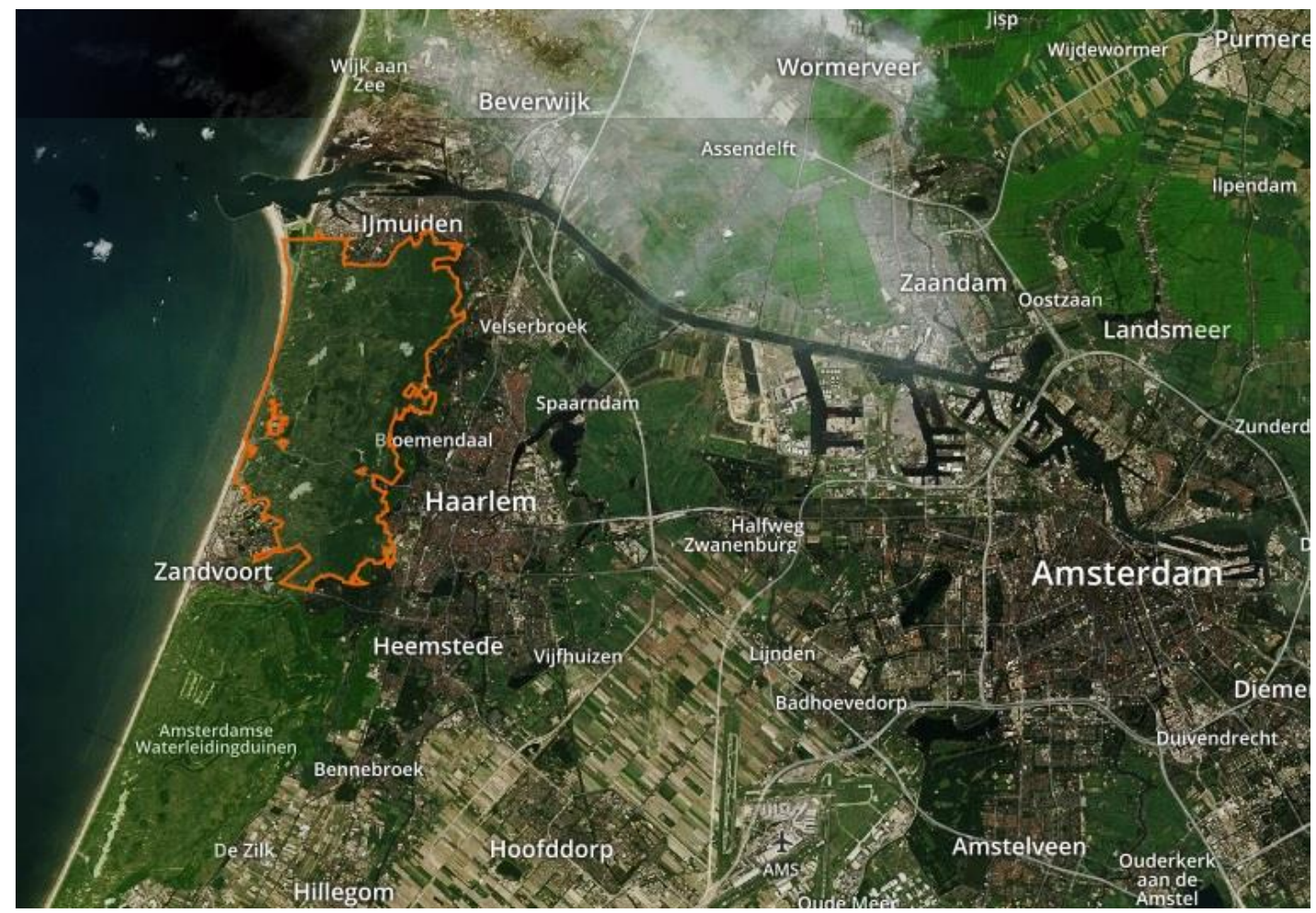

Fonte: IUCN e UNEP-WCMC (2015).

O PNZK apresenta grande relevância biológica, caracterizada por uma paisagem de dunas calcárias, extensas praias e florestas costeiras, com a presença de importantes espécies e habitats para a região. Além disso, apesar do Parque estar praticamente isolado pela sua posição geográfica e inserido em um local altamente urbanizado, ele apresenta uma conexão com outra área protegida contígua $^{77}$ através de um ecoduto, uma espécie de passarela de vegetação e terra, reproduzindo o habitat da fauna local.

De acordo com a gestão, até o início do século XIX, o uso do solo na região era comumente utilizado para fins agrícolas e para criação de gado, fins que resultaram em intensa exploração e degradação das dunas. Após esse período, os moradores da região passaram a concentrar as

\footnotetext{
${ }^{77}$ Amsterdam Water Supply Dunes. Em holandês: Amsterdamse Waterleidingduinen.
} 
atividades agrícolas em parcelas, onde algumas ainda se encontram em uso para cultivos tradicionais.

O PNZK apresenta um grande patrimônio histórico-cultural. No seu interior, verifica-se a presença de diversas fortificações de concreto, utilizadas pelo exército alemão durante a $2^{\mathrm{a}}$ Guerra Mundial; vestígios de propriedades datadas de mais de 2000 anos (Fazenda Frisian), descobertos através de escavações arqueológicas; uma série de propriedades centenárias luxuosas (tais como: Caprera, Elswout e Koningshof) de antigos comerciantes que vieram de Amsterdã para se estabelecer próximo a costa. Nesse contexto, por estar inserido no centro da região metropolitana de Amsterdã (capital e a cidade mais populosa do Reino dos Países Baixos), também contribui para a qualidade de vida das populações do entorno, trazendo inúmeros benefícios.

O Plano de Manejo do Parque foi finalizado em 2014 e possui uma visão de dez anos (20142024). De maneira geral, busca direcionar suas ações pautadas em cinco objetivos principais: I) manter e proteger as paisagens e patrimônio histórico-cultural; II) estimular e aumentar as oportunidades de recreação de baixo impacto; III) fornecer incentivos para a comunicação e educação; IV) promover a pesquisa científica e V) promover o aumento da conscientização dos residentes locais, visitantes, operadores e gestores.

Observa-se que a missão comum da gestão do PNZK é gerir, proteger e desenvolver o parque de maneira sustentável, fomentar o desenvolvimento de pesquisas científicas e assegurar o acesso ao público. Além disso, considera como vital que os residentes do entorno e visitantes apoiem os seus objetivos. Para isso, verifica-se a existência de um Conselho Consultivo, composto por membros da sociedade civil, organizações gestoras, membros de órgãos públicos, e organizações educacionais e de pesquisa. Neste Conselho são decididos de maneira conjunta e participativa sobre os planos anuais a serem executados.

Segundo a gestão do PNZK, existem muitos voluntários que auxiliam em diversas tarefas, tais como no apoio ao Centro de Visitantes, na orientação dos turistas; nas ações de manejo de habitats e espécies em geral; na monitoria ambiental em excursões com escolas e grupos diversos; no apoio aos cursos oferecidos pelo Parque; na realização de inventários e programas de monitoramento de espécies; no auxílio em campanhas de conscientização, entre outros. Desse modo, a gestão alega que os voluntários são indispensáveis para alcançar os objetivos do Parque.

Conforme mencionado anteriormente, um dos objetivos principais do Parque é aumentar a comunicação e divulgação da área para o público local. Desse modo, observa-se que todas as 
atividades e informações sobre o Parque são divulgadas em veículos de mídia locais (rádio, TV e jornais), através de um website interativo, cartilhas educativas, folders e mais recentemente foi desenvolvido um aplicativo para celulares, contendo diversas informações para o visitante.

Em relação aos recursos financeiros da área, o Ministério da Agricultura, Natureza e Qualidade Alimentar concede subsídios anuais ao Parque para implementar seus planos, com base nos programas de ação do seu Plano de Manejo, bem como fornece apoio pontual a atividades que visem melhorar a qualidade do sistema de Parques Nacionais. Contudo, verifica-se que a partir de 2011, o governo reduziu consideravelmente os recursos e o trabalho da organização IVN.

Assim, a gestão alega que o Parque vem buscando novas fontes de recursos e maior suporte para a conservação da área, tanto nos setores públicos como privados. De maneira geral, atualmente quem financia a maior parte da área são as organizações para a conservação da natureza, onde alguma delas recebem dinheiro do Governo, ao passo que outras a partir de recursos próprios. Desse modo, os recursos financeiros dos últimos cinco anos foram adequados para realizar ações de manejo críticas. Contudo, ainda não há previsão financeira estável a longo prazo.

\subsubsection{Pressões e Ameaças ${ }^{78}$}

As principais pressões e ameaças do PNZK foram avaliadas pela sua gestão segundo um grau de intensidade (figura 33).

\footnotetext{
${ }^{78}$ Apêndice XIX.
} 
Figura 33. Principais pressões e ameaças do Sítio Natura 2000 e Parque Nacional Zuid-Kennemerland (PNZK). As pressões e ameaças avaliadas como severas possuem pontuação entre 25 a 64, as altas possuem pontuação entre 10 a 24 pontos, as moderadas entre 4 a 9 pontos, e por fim, as leves possuem de 1 a 3 pontos.

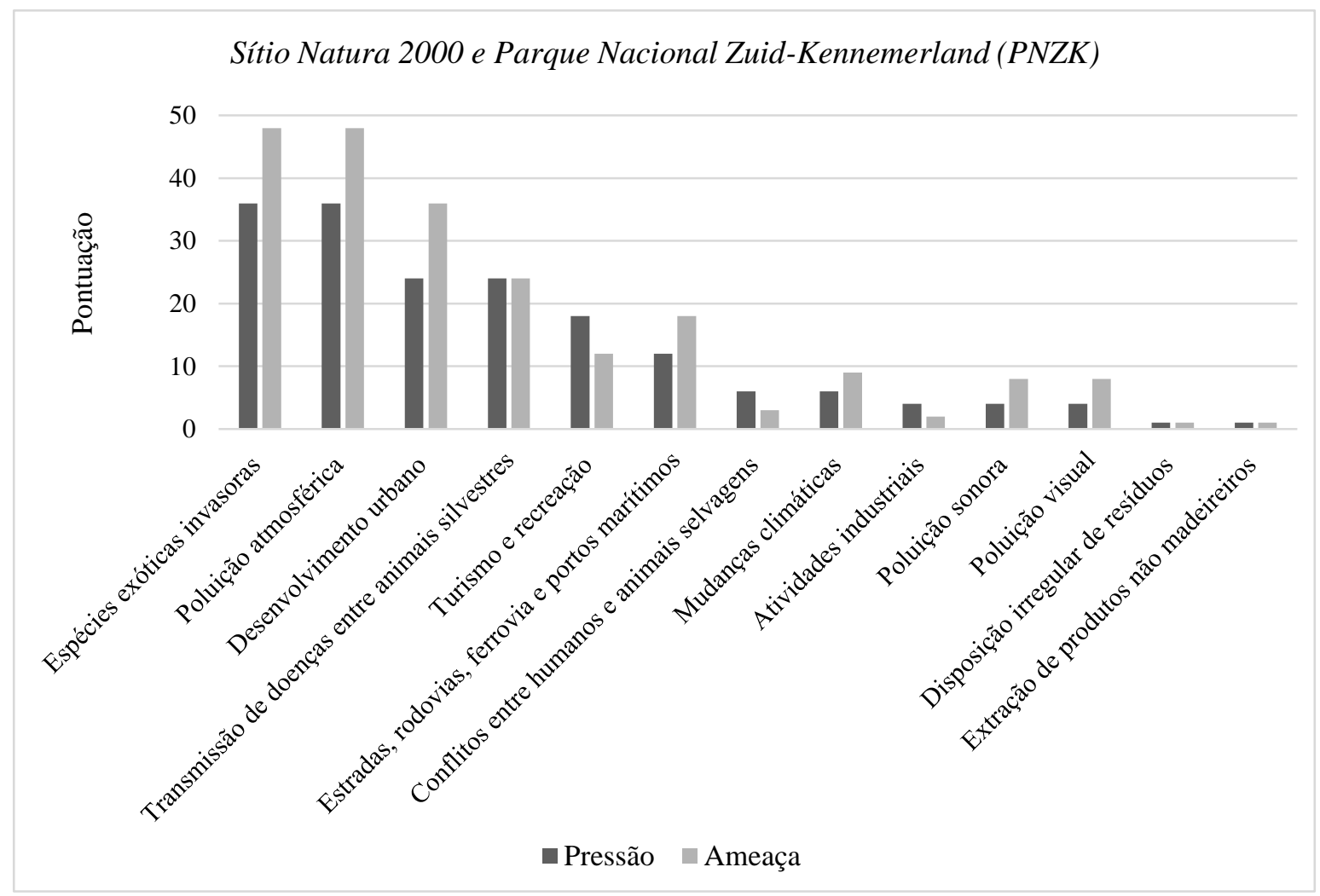

Fonte: Elaborado pela autora (2016), a partir das informações fornecidas pela gestão.

\section{Pressões severas:}

As pressões avaliadas como severas (pontuação de 25 a 64) são: espécies exóticas invasoras (36 pontos), as quais aumentaram drasticamente nos últimos cinco anos, bem como poluição atmosférica (36 pontos), a qual permaneceu constante nos últimos cinco anos.

A poluição atmosférica é proveniente da queima de combustíveis fósseis dos veículos motorizados, indústrias, agricultura, entre outros. Segundo a gestão, ela é um problema a nível nacional, devido principalmente a deposição de Nitrogênio. Como resultado, observa-se o acúmulo desse elemento químico, principalmente na região marítima, contaminando de maneira intensa habitats e espécies do PNZK.

Em relação as espécies exóticas invasoras presentes no PNZK, destacam-se as espécies de flora: Prunus serotina, Crassula helmsii, Fallopia japônica, bem como espécies dos gêneros botânicos Mahonia e Cotoneaster. Segundo a gestão, uma das formas de introdução dessas espécies ocorre através das propriedades particulares do entorno e vêm se espalhando rapidamente, 
principalmente nos habitats das dunas. Desse modo, verifica-se que o acúmulo de Nitrogênio, proveniente da poluição atmosférica, vem resultando no aumento de biomassa e consequentemente auxiliando no aumento da propagação desses indivíduos. Apesar dos grandes esforços que vêm sendo empregados no manejo, elas representam um problema grave à biodiversidade do Parque.

\section{Pressões altas:}

As pressões avaliadas com alto grau de intensidade (pontuação de 10 a 24) são: desenvolvimento urbano (24 pontos), que permaneceu constante nos últimos cinco anos; atividades de turismo e recreação (18 pontos), bem como a presença de estradas, rodovias, ferrovia e portos marítimos (12 pontos), os quais aumentaram ligeiramente nos últimos cinco anos, e por fim, a transmissão de doenças entre animais silvestres (24 pontos), a qual permaneceu constante.

O PNZK abrange quatro municípios, dentre eles destaca-se Haarlem, a capital da Holanda do Norte. Além disso, está localizado a cerca de $20 \mathrm{~km}$ de Amsterdã, cidade mais populosa do Reino dos Países Baixos e um dos principais centros financeiros da Europa. Desse modo, o PNZK está totalmente inserido na malha urbana, com habitações, comércios, indústrias e diversas vias de acesso no seu entorno imediato, sendo altamente pressionado pela urbanização.

O PNZK é uma importante região turística, recebendo cerca de 2 milhões de visitantes por ano. De maneira geral, o público procura por atividades de caminhadas, ciclismo, equitação, bem como visitação aos monumentos centenários presentes no interior da área protegida. Segundo a gestão, nos últimos anos, a grande maioria dos visitantes são provenientes da região. Contudo, verica-se um aumento dos visitantes estrangeiros e dos impactos resultantes, visto a crescente demanda turística na região metropolitana de Amsterdã (a gestão adverte que o turismo na região vem crescendo 10 a 20\% ao ano), sendo um novo desafio para eles. Além disso, o Parque entrou recentemente no roteiro oficial do guia turístico de Amsterdã ${ }^{79}$, o qual utiliza como marcketing "visite Amsterdã, conheça a Holanda".

Outra pressão considerada alta à área protegida é a presença de diversas estradas no seu entorno, bem como duas rodovias (N200 e N20) movimentadas e uma ferrovia que atravessam o seu território, impedindo a livre circulação de muitas espécies. Além disso, existem portos marítimos na costa, onde já existem projetos para suas expansões, os quais pretendem receber

\footnotetext{
${ }^{79}$ Conhecido como "I AMsterdam". Disponível em: < http://www.iamsterdam.com>. Acesso em: Abr 2016.
} 
maiores embarcações. Desse modo, a gestão espera um aumento considerável do fluxo de cargas e veículos nos próximos anos.

Por fim, observa-se também como uma alta pressão a transmissão de doenças entre animais silvestres, mais especificamente entre coelhos, animais herbívoros pastoreadores das dunas. Primeiramente, é importante ressaltar que os habitats das dunas devem ser ativos, isto é, não cobertos por uma vegetação densa, onde os nutrientes na sua superfície possibilitam o estabelecimento de espécies típicas desses locais. Desse modo, quando esses habitats estão densamente ocupados pela vegetação, isto é, quando as dunas estão "estagnadas", conduz ao desaparecimento de muitas espécies e consequentente afetam a biodiversidade da área. Logo, a presença de animais herbívoros pastoreadores é fundamental para a manutenção e conservação do Parque, os quais removem a camada superior de vegetação, desencadeando um processo natural de deslocamento das dunas.

Nesse contexto, alguns anos atrás, a manutenção das dunas era realizada apenas por essas espécies de coelhos. Contudo, a população desses animais foi altamente afetada por uma doença viral, o que segundo a gestão, foi introduzida ao Parque devido ao deslocamento de pessoas e animais, prejudicando seriamente a biodiversidade das dunas. A gestão acredita que eventos desse tipo são esperados para os próximos anos, visto o constante fluxo de pessoas e animais em áreas urbanas.

\section{Pressões moderadas:}

As pressões avaliadas como moderadas (pontuação de 4 a 9) e que aumentaram ligeiramente nos últimos cinco anos são: os conflitos entre humanos e animais selvagens ( 6 pontos), as mudanças climáticas (6 pontos), as atividades industriais (4 pontos) e a poluição sonora (4 pontos) e visual (4 pontos).

Observam-se conflitos entre humanos e animais selvagens no PNZK, decorrentes da super população de cervídeos no interior da área protegida, bem como verificam-se ocorrências de atropelamentos de algumas espécies nas vias de acesso que atravessam a área. De maneira geral, a fim de continuar a manutenção das dunas e controlar o problema com as espécies de coelhos, os cervídeos foram introduzidos no PNZK e encontraram condições ideais para se estabelecerem. Contudo, atualmente a população extrapolou a capacidade limite do Parque, trazendo prejuízos para a biodiversidade local. Logo, a solução para esse problema seria o abate dessas espécies, 
porém, a população local posicionava-se totalmente contra essa medida. Segundo a gestão, não havia uma comunicação efetiva sobre os impactos ocasionados por parte dessa super população.

Outro tipo de pressão moderada que a gestão do PNZK considera estar trazendo um impacto prejudicial à área são as mudanças climáticas. Segundo a gestão, observam-se alterações nos padrões climáticos na região, segundo os monitoramentos realizados. Como resultado, devido o Parque estar às margens do Mar do Norte, verificam-se um aumento no nível do mar, onde as previsões mostram que esta tendência irá continuar para os próximos anos.

Existem atividades industriais no entorno do Parque, as quais vem causando impactos prejudiciais à área nos últimos anos. Dentre os impactos, destacam-se a emissão de gases tóxicos resultando em poluição atmosférica e a contaminação das águas e dos solos por excesso de Nitrogênio. Além disso, os monitoramentos na região mostram que as atividades industriais do entorno potencializam as chuvas ácidas, acelerando a descalcificação dos solos e aumentando a acidez das dunas, e logo ameaçando as espécies típicas deste habitat. Segundo a gestão, diversos esforços vêm sendo empregados para mitigar esses impactos, e desse modo espera-se que essa pressão diminua de intensidade nos próximos anos ${ }^{80}$.

Outras pressões avaliadas como moderadas são a poluição sonora e visual. Por estar localizado em área urbana, verificam-se diversos tipos de ruídos, provenientes desde eventos realizados no entorno, sobrevôos de aeronaves e corridas de fórmula 1, bem como diversas luzes artificiais no entorno. Segundo a gestão, espera-se que essas pressões aumentem de intensidade nos próximos anos.

\section{Pressões leves:}

As pressões avaliadas como leves (pontuação de 1 a 3) são: disposição irregular de resíduos (1 ponto), atividade que permaneceu constante nos últimos cinco anos, bem como a extração de produtos não madeireiros (1 ponto), a qual aumentou ligeiramente nos últimos cinco anos.

Em relação aos resíduos, observam-se que estes (e.g. embalagens, restos de alimentos, etc.) são gerados pelos visitantes, os quais muitas vezes não os acondicionam adequadamente, gerando alguns impactos localizados. De maneira geral, a gestão alega que à disposição irregular destes ocorrem nas áreas de uso público que recebem maior número de pessoas. Além disso, também se verificam extrações esporádicas de produtos não-madeireiros por alguns visitantes, tais como

\footnotetext{
${ }^{80}$ Ações detalhadamente descritas no item "ações de conservação".
} 
plantas ornamentais, medicinais e espécies de cogumelos comestíveis, sendo pressões e ameaças leves.

Por fim, dos 13 tipos de pressões e ameaças identificadas, verificam-se que sete irão aumentar em algum nível de intensidade, devido principalmente ao aumento do desenvolvimento urbano e consequentemente dos impactos resultantes do processo de urbanização.

\subsection{Ações de Conservação}

O plano de manejo de uma área protegida é o produto final do processo de planejamento da área, o qual compõe uma das etapas do seu ciclo de gestão. Este, deve ser um ciclo dinâmico e conduzido de maneira contínua e participativa. Nesse sentido, o plano de manejo busca apresentar os valores da área protegida, os desafios que possam afetar prejudicialmente à área, bem como as ações necessárias a fim de manter ou melhorar a sua conservação e os seus atributos naturais (SPOELDER et al., 2015).

Observa-se que os planos de manejo das áreas protegidas do presente estudo são direcionados de acordo com uma visão de planejamento entre 10 a 20 anos, com objetivos gerais, específicos, metas e indicadores. Além disso, ressalta-se que as ações de conservação destes planos fazem parte do processo de planejamento operacional da área protegida. Logo, as ações executadas devem ser frequentemente avaliadas e revisadas, em um processo iterativo, não devendo serem vistas como uma série de prescrições fixas. Ainda, observa-se que os órgãos gestores responsáveis pela elaboração dos planos de manejo seguem as orientações da Rede Natura 2000 e da IUCN, bem como as diretrizes e legislações de seus países.

Desse modo, observa-se que todas as áreas protegidas do presente estudo buscaram implementar algum tipo de ação de conservação para as pressões que vêm sofrendo. Logo, o presente tópico tem como objetivo analisar e discutir sobre as iniciativas que vêm sendo implementadas e como seus órgãos gestores vêm resolvendo seus principais problemas.

\section{Desenvolvimento urbano}

De acordo com o Artigo $6^{\circ}$ da Diretiva de Habitats da Rede Natura 2000, para todos os planos ou projetos que possam afetar de forma significativa os sítios Natura 2000, são realizadas avaliações adequadas pelas autoridades nacionais competentes, as quais irão autorizar ou não a implementação destes, sem que haja prejuízos a integridade das áreas protegidas. Desse modo, verifica-se que a gestão dessas áreas é responsável pela elaboração de manifestações através de 
pareceres técnicos, orientando as restrições e permissões dos planos e projetos de impactos significativos. Em seguida, os pareceres são encaminhados para as autoridades nacionais competentes para avaliação. Caso seja necessário realizar um plano ou projeto de reconhecido interesse público, as autoridades nacionais devem adotar todas as medidas compensatórias necessárias para assegurar a proteção das áreas protegidas afetadas. Segundo as gestões das áreas protegidas do presente estudo, esta é a principal forma de impedir que novos empreendimentos de alto impacto venham comprometer os objetivos dos sítios Natura 2000.

Nesse contexto, os órgãos gestores em parceria com os Estados-membros (responsáveis pela nomeação das áreas protegidas), de maneira geral, devem elaborar relatórios sobre a aplicação das disposições adotadas segundo as Diretivas da Rede Natura 2000. Os relatórios devem conter todas as ações de conservação adotadas, informações sobre o estado de conservação das espécies e habitats protegidos, bem como sobre os resultatos de monitoramento aplicados. Desse modo, os relatórios são disponibilizados para o público e analisados pela Comissão da Rede Natura 2000, formada por uma rede de especialistas. Caso os resposáveis pelas áreas protegidas não elaborem relatórios segundo as normas requeridas num determinado período, a Comissão pode iniciar uma série de ações judiciais, as quais podem resultar em multas de valor elevado. Isso funciona como uma forte pressão para os países para resolverem os seus principais problemas.

Também se verificam articulações institucionais e parcerias com organizações e agências públicas e privadas no processo de gestão das áreas protegidas do presente estudo, como forma de mitigar a pressão de desenvolvimento urbano do entorno desses locais. De maneira geral, membros de órgãos públicos, privados e da sociedade civil participam diretamente das discussões de políticas ambientais e planejamento territorial dos municípios abrangidos, bem como de reuniões via Conselhos Consultivos. Desse modo, visando construir, promover e preservar a identidade das áreas protegidas, através de uma gestão participativa, todas as áreas do presente estudo buscaram promover uma comunicação efetiva com as suas comunidades do entorno. Através das equipes de funcionários e grupos de voluntários, são realizadas reuniões públicas periodicamente, onde a comunidade pode trazer os seus problemas e preocupações, bem como os gestores podem falar sobre as diversas questões relacionadas aos locais.

Das parcerias com organizações e agências públicas e privadas no processo de gestão do sítio LM, criou-se um projeto inovador chamado City Meets Nature. Este, busca compatibilizar a conservação da área protegida com o desenvolvimento urbano do entorno, bem como o 
fortalecimento da imagem da área para a população urbana. Além disso, apresenta como desafios integrar a área protegida com demais áreas naturais do entorno (via corredores ecológicos e passagens de fauna) e abordar estratégias para uma melhor cooperação entre as instituições responsáveis pela área, tais como os órgãos municipais e estaduais.

Outro exemplo de articulações e parcerias visando enfrentar o desenvolvimento urbano desenfreado do sítio SF foi a criação do Structural Visual Project. De maneira geral, cada umas das três regiões que formam a área protegida possuem planos de manejo específicos para seus territórios, de acordo com os diferentes objetivos de cada uma. No entanto, os gestores perceberam a necessidade de haver uma abordagem coordenada para conectar as diferentes regiões, alcançando os objetivos de conservação previstos e atendendo o grande número de visitantes. Desse modo, em 2008, as três regiões decidiram trabalhar em conjunto. Em 2013, o projeto foi finalizado, apresentando uma visão de planejamento para os próximos vinte anos e abordando algumas questões, tais como: quais ações são necessárias para mitigar as pressões e ameaças mais frequentes? Como lidar com problemas relacionados a expansão do desenvolvimento urbano?

Desse modo, os gestores assinaram um acordo formal para trabalhar na mesma filosofia e legislação, planejando em conjunto as ações para melhorar a sua preservação, transformando-a em uma área protegida de identidade mais forte. Além disso, não apenas as três regiões, mas também as áreas verdes ${ }^{81}$ nos arredores da área protegida entraram no acordo, totalizando 5.000 ha.

Durante os anos de 2005 a 2008, houve uma série de reuniões com a participação ativa da sociedade civil (e.g. associações ambientais, ONGs, agências de turismo, políticos, voluntários, membros de universidades) e órgãos municipais e estaduais. De acordo com a gestão, o desenvolvimento do Structural Visual Project foi apenas possível devido a este grande envolvimento do público. Após a assinatura do acordo, foi formado um grupo de coordenação, o qual possui como objetivo auxiliar na implementação das diferentes ações de conservação e supervisionar as três regiões. Além disso, o grupo ajuda no processo de integração dos visitantes com a área protegida, desenvolvendo atividades de educação ambiental, bem como divulgando informações sobre a área protegida através dos veículos de comunicação regionais (e.g. revistas eletrônicas, jornais, rádio, TV).

Outro exemplo de parcerias com organizações públicas e privadas é verificada no PNZK. Nesse sentido, a gestão do Parque é formada por diferentes organizações e instituições, as quais

${ }^{81}$ Tais como: Bois de la Cambre, Arboretum of Tervuren, Kapucijnenbos e Solvay Domain. 
via Conselho Consultivo buscam administrar e planejar ações para os principais desafios relacionados ao Parque, em especial para o desenvolvimento urbano do entorno. Segundo a gestão, os membros do Conselho participam ativamente das reuniões de planejamento territorial e políticas ambientais dos municípios abrangentes do Parque, buscando sempre enfatizar aos líderes dos planos e projetos sobre a importância em se manter áreas verdes e conexões no entorno do parque, bem como monitoraram periodicamente as atividades que ocorrem nas áreas limítrofes ao sítio. Além disso, a gestão alega que as parcerias já estão gerando resultados positivos, visto que diversos municípios abrangentes vêm buscando cada vez mais contactar o Parque nos processos de decisão que envolvam a conservação do território. Desse modo, órgãos públicos, privados e membros da sociedade civil participam ativamente do processo de gestão, os quais planejam ações para um período de 10 anos, implementando-as juntos via Conselho Consultivo.

Além das manifestações através de pareceres técnicos, articulações institucionais e parcerias com uma vasta rede de organizações públicas e privadas, verifica-se um projeto que propõe conexões com outras áreas naturais, para a área protegida SF. De maneira geral, este projeto faz parte de um dos objetivos primordiais da gestão, que busca aumentar as áreas verdes ${ }^{82}$ no entorno da área protegida, ação que ocorreu entre o período de 2010 a 2014, com o apoio dos municípios envolvidos e a equipe de gestão. Ademais, também se verifica a expansão dos limites da área protegida, onde o objetivo do novo zoneamento é garantir uma maior proteção nas zonas mais frágeis, bem como das zonas adjacentes, aumentando a conexão com outros habitats.

Nesse contexto, verificam-se também programas de proteção nas áreas protegidas do presente capítulo (com exceção do sítio LM), onde são realizadas ações de fiscalização e monitoramento no interior e entorno desses locais. Além disso, elas contam com o apoio de agências locais de policiamento.

Outro tipo de atividade observada em todas as áreas do presente estudo é a realização de atividades de educação ambiental com os grupos visitantes, visando a sensibilização pública frente aos desafios urbanos. Como por exemplo, observa-se para o sítio LM, a organização do evento anual City Information Day (no âmbito do projeto City Meets Nature), com o objetivo de promover a educação ambiental e um fórum de discussão sobre os desafios urbanos para os habitats e espécies protegidos. Além disso, foi criado um logotipo para o evento, visando fortalecer a identidade visual da área protegida.

\footnotetext{
${ }^{82}$ Tais como: Voer, Laan, IJse, Woluwe, Argentina, Meerdaalwoud e Hallerbos.
} 
Para o caso do sítio SF, os funcionários com o apoio de grupos voluntários recebem anualmente vários grupos visitantes, com o objetivo de desenvolver ações participativas com a comunidade. De maneira geral, os colaboradores vêm buscando conscientizar os indivíduos sobre a importância biológica, social e econômica da área protegida, bem como sobre os desafios urbanos enfrentados. Já para o PNZK, a educação ambiental e a participação da sociedade civil na gestão são um dos principais objetivos da área, onde são desenvolvidas diversas atividades que buscam desafiar a sociedade a olhar para os problemas do Parque e a discutir ativamente em conjunto as possíveis soluções.

\section{Espécies exóticas invasoras}

As espécies exóticas invasoras representam uma grande ameaça para a biodiversidade nativa da Europa, e encontram-se em rápido crescimento nos últimos anos (EUROPEAN COMISSION, 2010). Além de afetarem prejudicialmente a biodiversidade europeia, os impactos observados são diversos, tais como na saúde humana, na produção alimentar e na economia (EUROPEAN COMISSION, 2010). A disseminação dessas espécies vem ocorrendo de maneira acelerada devido a expansão do transporte de mercadorias, atividades comerciais e turísticas, principalmente nas áreas urbanas (EUROPEAN COMISSION, 2010).

O Plano de Ação Comunitário sobre Biodiversidade de 2006 destacou o problema das espécies exóticas invasoras e a necessidade de uma abordagem estratégica comum aos países da UE (EUROPEAN COMISSION, 2010). Além disso, muitos países da Europa possuem planos e legislações específicas, ao passo que outros não (EUROPEAN COMISSION, 2010). Desse modo, foi estabelecido em 2008 um plano comum internacional de combate a essas espécies, intitulado "Por uma estratégia da UE em matéria de espécies invasoras" e dividido em três etapas: I) Prevenção: abordagem mais adequada e econômica, visando o controle das espécies nas fronteiras e troca de informações a nível regional, nacional e internacional; II) Erradicação: ações de manejo eficazes quando as espécies já estão estabelecidas e III) Confinamento: caso a erradicação não seja possível, é necessário aplicar ações de controlo a longo prazo a fim de impedir a disseminação das espécies invasoras (EUROPEAN COMISSION, 2010).

Desse modo, verifica-se que as áreas protegidas do presente estudo vêm utilizando essa abordagem estratégica para o combate às espécies exóticas invasoras (detecção, monitoramento, prevenção, erradicação e confinamento). Contudo, por ser um trabalho de manejo permanente, oneroso e muitas vezes sem resultados garantidos, os gestores decidiram criar uma equipe de 
voluntários, para aumentar as chances de sucesso na luta contra essas espécies. As equipes de voluntários são treinadas e qualificadas por técnicos e especialistas em manejo florestal. Além disso, segundo as gestões das áreas protegidas, também são realizadas atividades de sensibilização com os moradores do entorno imediato.

Ainda nesse sentido, verifica-se que a gestão do sítio LM, no âmbito do Projeto City Meets Nature, estabeleceu uma parceria com o Centro de Meninas de Klagenfurt ${ }^{83}$, o qual oferece aconselhamento de carreira, apoio psicológico e orientação para mulheres jovens do município. $\mathrm{O}$ objetivo é trazer esse grupo de jovens para dentro da área protegida e através da educação ambiental ensiná-las sobre temas em conservação e trabalhos manuais de campo, conciliando na luta contra as espécies exóticas invasoras. Dentre as atividades, elas recebem orientações de carreira através de palestras com profissionais (professores, ecologistas, monitores ambientais, especialistas em silvicultura e arquiteto paisagista) sobre trabalhos diversos relacionados à conservação do meio ambiente. Outra parceria estabelecida foi com o Departamento de Jardinagem do município, através da contratação de pessoas desempregadas e trabalhadores de rua.

Por fim, os gestores contam com o apoio de um Sistema de Alerta Precoce e de Informação, intitulado DAISIE ${ }^{84}$ (Delivering Alien Invasive Species Inventories for Europe), um projeto que contém dados sobre as espécies e invasões biológicas em toda a Europa, orientações e técnicas para erradicação. A plataforma é permanentemente atualizada por especialistas e financiada pela UE.

\section{Poluição atmosférica}

A poluição atmosférica traz inúmeros prejuízos para a saúde da população e para o meio ambiente, afetando prejudicialmente em diferentes níveis as áreas protegidas do presente estudo. É causada principalmente por atividades econômicas (e.g. indústrias, meios de transportes, energia e agricultura) e por ser transportada por entre fronteiras nacionais, é necessária uma abordagem cooperativa nos níveis local, internacional e global (EUROPEAN COMISSION, 2013).

Convenções internacionais e outros tratados têm desempenhado um papel fundamental na sensibilização e no estabelecimento de políticas para a redução das emissões de poluentes na UE, a qual adotou medidas legislativas ${ }^{85}$ a fim de melhorar a qualidade do ar do continente (EUROPEAN COMISSION, 2013). Desse modo, verificam-se dois instrumentos principais que

\footnotetext{
${ }^{83}$ Em austríaco: Mädchenzentrum Klagenfurt.

${ }^{84}$ Disponível em: <http://www.europe-aliens.org/>. Acesso em: Abr 2016.

${ }^{85}$ Disponível em: <http://ec.europa.eu/environment/air/legis.htm>. Acesso em: Abr 2016.
} 
tratam da poluição atmosférica: I) A Diretiva da UE relativa à qualidade do ar do ambiente (2008), que estabelece as normas relativas à qualidade do ar para o ozônio, materiais particulados, óxidos de nitrogênio, metais pesados perigosos e outros poluentes; II) A Diretiva relativa aos limites nacionais de emissões (2001), que limita as emissões globais de dióxido de enxofre, óxidos de nitrogênio, amoníaco e compostos orgânicos voláteis (EUROPEAN COMISSION, 2013).

Desse modo, as gestões das áreas protegidas do presente estudo alegam que este problema vem sendo resolvido em âmbito nacional e as ações realizadas por eles consistem na promoção de discussões sobre o tema nos projetos de educação ambiental, desenvolvidos com os grupos visitantes e com as comunidades do entorno. Ademais, verificam-se programas de monitoramento climático (com exceção do sítio LM).

\section{Caça e pesca}

As atividades de caça e pesca foram avaliadas como pressões apenas para o sítio LM. Logo, apesar de serem atividades legais, ambas vêm impactando negativamente espécies e habitats protegidos. Nesse sentido, para as atividades de pesca, a gestão alega que a área protegida é o único local público do município de Klagenfurt onde os praticantes podem utilizar, além do fato deste obter receita com a emissão de licenças para os praticantes de ambas as atividades, sendo muito difícil que tais atividades se encerrem. Desse modo, nenhuma ação tem sido adotada para a mitigação desses impactos nos últimos anos. Segundo a gestão, isso ocorre pelo fato de serem atividades legais e com a presença de associações comunitárias fortes. No entanto, durante o processo de revisão do plano de manejo, a gestão alegou que buscará sensibilizar as associações responsáveis, realizar acordos formais ressaltando as restrições da área protegida, bem como fiscalizar os locais utilizados pelos praticantes.

\section{Turismo e recreação}

Observa-se que cada vez mais a população urbana vem procurando por áreas naturais para escapar do ambiente caótico das cidades, em geral para realizar atividades turísticas e recreativas (TRZYNA, 2014). Como resultado, verificam-se que todas as áreas protegidas do presente estudo sofrem com essa pressão, sendo locais muito atrativos para as populações dos seus municípios. Logo, as gestões vêm adotando uma série de ações para conciliar a proteção de seus territórios com as necessidades recreativas das populações locais. Assim, todos acreditam que a área protegida oferece a oportunidade e possui o potencial de atuar como catalisadora de mudanças de estilo de 
vida, onde a população urbana deve aprender a cuidar e a reconhecer sobre a sua importância e seus benefícios gerados.

Sabendo disso, verifica-se que todas as gestões realizam pesquisas periódicas com os seus visitantes (e.g. contagem de indivíduos, conhecimento destes sobre a área, locais mais utilizados, usos frequentes, etc), a fim de obter um melhor entendimento sobre a dinâmica da área protegida, bem como sobre as urgências de cada local. Desse modo, observa-se que todas as áreas do presente estudo buscaram melhorar a sua sinalização, através da implantação de placas sinalizadoras, distribuição de folders e banners, ressaltando sobre o seu tipo de categoria, espécies e habitats protegidos, usos permitidos e não permitidos. Nesse sentido, visando melhorar a infraestrutura para os visitantes, foi estabelecido um centro de visitantes (com exceção para o sítio LM), oferecendo todas as informações necessárias, sala de exibições de filmes, cafeteria, atividades turísticas e recreativas, visitas guiadas com monitores ambientais, aluguel de bicicletas, etc. É neste centro que os monitores ambientais realizam o trabalho de abordagem e recepção dos visitantes, projetos de educação ambiental e um controle do número de visitantes.

Já para os sítios SF e o PNZK, verificam-se em seus territórios importantes patrimônios histórico-culturais. Assim, as gestões aproveitaram o potencial turístico histórico desses locais, transformando as áreas protegidas em locais de atração histórica ${ }^{86}$, onde o visitante entra em contato com a história local revelada pelos monumentos arqueológicos, edifícios e fazendas centenários. Desse modo, respeitando a capacidade de suporte das áreas protegidas, a gestão buscou-se unir a conservação do patrimônio histórico com a preservação da área protegida. Esta combinação fortalece os laços com a comunidade envolvente, promovendo maior contato com a área protegida.

Outra ação em comum é a concentração de atividades recreativas em locais menos vulneráveis e mais afastados das zonas de preservação mais sensíveis, aquelas com maior número de espécies e habitats protegidos. Como por exemplo, para o sítio LM, havia uma antiga área utilizada por banhistas e para acampamento, de difícil acesso e localizada em uma zona mais

\footnotetext{
${ }^{86}$ Para o sítio SF houve a restauração de monumentos históricos (como por exemplo, foi criado um Museu da Floresta - ou Musée de la Forêt - no edifício antigo de Groenendaal, com a exposições de espécies da flora e fauna local, história e gestão. Outro exemplo é o antigo convento Rouge Cloître Abbey, onde atualmente é uma instituição comunitária que apresenta exposições de literatura e arte. Além disso, os visitantes podem encontrar no Castelo $L a$ Hulpe um parque de caminhada, eventos culturais e musicais), transformando-os em reservas arqueológicas, a fim de melhorar a conservação destes locais. Desse modo, a principal preocupação das gestões é conservar esse patrimônio para as gerações futuras. Similarmente, para o caso do PNZK, o turista tem a oportunidade de visitar antigos campos de batalha da $2^{\mathrm{a}}$ guerra mundial e uma série de propriedades milenares e centenárias históricas.
} 
vulnerável da área protegida. Os visitantes geralmente causavam desordem às espécies e habitats protegidos, ruídos e despejavam irregulamente resíduos no local. Assim, no âmbito do projeto City Meets Nature, uma das ações foi o fechamento do local de banho público e o deslocamento do acampamento para uma zona menos vulnerável, adjacente ao parque urbano Europark e com maiores facilidades de acesso e uso. Foram colocadas placas sinalizadoras sobre o uso não autorizado de atividades recreativas e a área foi cercada, tornando-se uma zona central silenciosa.

Para a SF, as atividades recreativas foram concentradas em pontos estratégicos da área protegida (nas bordas), visando reduzir a pressão nas áreas mais sensíveis e frágeis. Para isso, a gestão criou seis portões principais, isto é, seis zonas recreativas ${ }^{87}$. Em geral, estes portões estão equipados com inúmeras facilidades, tais como estacionamento, placas informativas para visitantes, bancos, mesas, banheiros, trilhas claramente marcadas para pedestres e ciclistas, playgrounds, etc. Nos arredores dos portões, os visitantes podem encontrar cafés, restaurantes, lojas e transporte público acessível (ônibus, bicicleta, bonde, metrô, trem). Para tornar esse projeto possível, houve a participação dos órgãos municipais e estaduais, empresários, organizações e voluntários. Além disso, cada uma das seis entradas possui uma equipe de trabalho, que é responsável por transformar o local em um lugar atrativo ${ }^{88}$.

O PNZK está em um dos roteiros mais procurados pelos visitantes da região de Amsterdã, recebendo milhares de visitantes anualmente. Segundo a gestão, o número de visitantes vem crescendo rapidamente, e para tanto, é necessário agir de maneira estratégica. Desse modo, as entradas são posicionadas de maneira lógica, relativas as vias de acesso principais e áreas residenciais adjacentes, com zonas recreativas e facilidades próximas. Além disso, o Parque vem passando por um processo de certificação de turismo sustentável, intitulado e traduzido como “Carta Europeia do Turismo Sustentável em Áreas Protegidas" ${ }^{89}$. De maneira geral, é uma ferramenta de gestão prática, a qual permite às áreas protegidas europeias desenvolverem o turismo de forma sustentável. A certificação é dada pela Federação EUROPARC ${ }^{90}$, uma rede de áreas protegidas europeias que tem como objetivo melhorar a gestão destes locais.

\footnotetext{
${ }^{87}$ Hippodrome of Bosvoorde-Ukkel, Rouge-Cloître Abbey, Park of Terhulpen, Groenendaal, Jezus-Eik e Solvay domain in Terhulpen.

${ }^{88}$ Como por exemplo, a entrada Bosvoorde-Uccle era um velho hipódromo caído em desuso por mais de vinte anos. Assim, o governo de Bruxelas decidiu renovar os edifícios antigos, revitalizando a área para os visitantes, transformando-a em um local de lazer. Além de melhorar a visibilidade de toda a área protegida, os responsáveis querem criar laços sociais com os arredores, bem como melhorar a cultura, lazer e educação para os cidadãos.

${ }^{89}$ The European Charter for Sustainable Tourism in Protected Areas.

${ }^{90}$ Disponível em: <http://www.europarc.org/>. Acesso em: Abr 2016.
} 


\section{Mudanças climáticas}

As mudanças climáticas foram avaliadas como um evento prejudicial aos sítios SF e PNZK. Em relação ao primeiro, grande parte de seu território é composto por espécies de faia-europeia (Fagus sylvatica L.), isto é, essa zona possui baixa biodiversidade e maior vulnerabilidade à disseminação de doenças e pragas, bem como às mudanças climáticas ou eventos catastróficos, podendo resultar em declínio da sua população e até mesmo extinção. Sabendo dessa preocupação, estudos relacionados às mudanças climáticas vêm mostrando os problemas futuros nesta zona, exigindo ações de manejo específicas para os próximos anos. Para tanto, a gestão optou por aumentar a biodiversidade local, reduzindo pela metade a área coberta por espécies de faia-europeia (Fagus sylvatica L.), e introduzindos espécies novas, com diferentes idades e tamanhos. Como resultado, espera-se uma Floresta mista, com indivíduos jovens e diversificados, preservando ao mesmo tempo espécies mais velhas em seu habitat natural. Além disso, a mesma estratégia tem sido abordada nas bordas da área protegida, também vulneráveis devido o contato com o ambiente urbano.

A regeneração tem sido realizada em 15 ha por ano (9 ha de espécies de faias foram preservados e 6 ha foram transformados em uma floresta mais jovem), totalizando em vinte anos 350 ha. Segundo a gestão, já é possível ver uma área protegida mais estável e forte, com maior variedade de espécies.

Para o caso do PNZK, os habitats das dunas funcionam como barreiras, protegendo as cidades de inundações marinhas. Contudo, segundo monitoramento realizado pela gestão, verificase um aumento no nível do mar nos últimos anos, a qual continuará a aumentar para os anos seguintes. Para piorar, dunas com densa vegetação se tornam fixas, acidificam e levam ao desaparecimento de espécies nativas típicas desse habitat. Desse modo, dunas estagnadas são seriamente afetadas pelas inundações marinhas e consequentemente pelo aumento do nível do mar, visto que impedem com que a areia seja transportada pelo vento e que os solos também aumentem de nível. Logo, a gestão do Parque em parceria com os órgãos municipais responsáveis pela costa marinha vem realizando pesquisas e ações de manejo para que as dunas aumentem de nível conforme o avanço do nível marinho. Para tanto, a camada superior de velhas dunas vem sendo removidas (com a introdução de animais herbívoros pastoreadores), desencadeiando assim um processo natural que enriquece e aumenta a biodiversidade da área, enquanto molda as próprias dunas. 


\section{Estradas e rodovia}

Verificam-se que todas as áreas protegidas do presente estudo são afetadas prejudicialmente seja por estradas, rodovias, ferrovias ou portos. De maneira geral, são amparadas legalmente pelas Diretivas da Rede Natura 2000, onde através de manifestações em pareceres técnicos da gestão, orienta-se sobre as restrições e permissões para os planos e projetos relacionadas às infraestruturas lineares que possam trazer impactos prejudiciais significativos à área protegida. Logo, os pareceres são encaminhados para as autoridades nacionais competentes para avaliação, a qual irá autorizar ou não os planos ou projetos.

Também se verificam a adoção de ações de compensação ambiental pelas concessionárias responsáveis em parceria com instituições públicas, privadas, organizações de conservação da natureza e sociedade civil, para todos os casos de estudo. Como por exemplo, existe uma estrada (Südring) que corta o sítio LM em três partes, resultando em atropelamentos e fragmentação da área. A fim de se evitar esses impactos, foram criadas diversas passagens de faunas para pequenos animais, conectando assim habitats e espécies à outra área protegida (conhecida como Schrottkogel). Além dos túneis, foram criados dois corpos d'água para anfíbios e estruturas para espécies de répteis hibernam durante o inverno. Ademais, a instalação dessas infraestruturas vem sendo monitoradas pela equipe de gestão e pela Nature Conservation Agency of Klagenfurt ${ }^{91}$.

De maneira similar, a SF também é cortada e cercada por estradas, ferrovias e rodovias, resultando na morte de aproximadamente cinquenta animais a cada ano, segundo os dados passados dos monitoramentos realizados pela equipe de gestão. Logo, um conjunto de ações se mostraram necessárias a fim de promover conexões com outros habitats e evitar os impactos da fragmentação. Desse modo, desde o ano de 2013 a gestão vem implementado um grande projeto denominado Life + OZON, a fim de evitar atropelamentos e preservar as espécies de fauna, com previsão para ser finalizado no ano de 2017. Este projeto contou com diversos parceiros, tais como as agências ANB, IBGE e AWV (Agência de Estradas e Tráfego), Departamento de Meio Ambiente e Energia de Bruxelas e os municípios de Overijse e Hoeilaart. Em suma, este projeto tem quatro objetivos principais: I) criar infraestruturas verdes (duas pontes verdes ${ }^{92}$, onze novos eco-túneis ${ }^{93}$ e quatro

\footnotetext{
${ }^{91}$ Em austríaco: Arge Naturschutz.

92 As pontes verdes permitirão a passage de animais pequenos a grande porte, com uma extensão de aproximadamente 60 metros. Para encontrar um nome que fosse compreendido em todas as línguas da região, a gestão elaborou uma pesquisa no site da área protegida.

93 Também conhecidas como passagens de fauna.
} 
pontes de árvores ${ }^{94}$ ); II) restaurar dezoito túneis e galerias antigas; III) construir cercas e estruturas de orientação para animais selvagens ${ }^{95}$ e IV) monitorar, sensibilizar e comunicar com a população local $^{96}$. Por fim, as ações de conservação já começaram a mostrar os primeiros resultados, com o aparecimento de novas espécies (e.g. Saxicola rubicola e Capreolus capreolus), árvores, arbustos, bosques e a diminuição de aproximadamente $90 \%$ dos atropelamentos.

Para o PNZK, a área é atravessada por estradas movimentadas e uma ferrovia, onde não é mais possível a livre circulação nas dunas para muitas espécies. A partir de vários estudos realizados na última década, diversas ações foram planejadas para evitar a fragmentação de habitats e espécies, com diversos atores envolvidos, tais como órgãos estaduais (Holanda do Norte), órgãos municipais (Bloemendaal), agência de água PWN, Comissão Florestal, organizações de conservação da natureza, voluntários e ambientalistas. Desse modo, foram planejadas três pontes verdes ${ }^{97}$ e diversas passagens de fauna, conectando um total de 7.0000 ha, as quais serão finalizadas até o ano de 2018.

\section{Poluição sonora}

A poluição sonora constitui um importante problema de saúde ambiental na Europa e ocorre quando a exposição prolongada de ruídos gera efeitos negativos para a saúde dos indivíduos, causada muitas vezes pelo tráfego de veículos em rodovias, estradas, ferrovias, aeroportos, indústrias, construções, eventos em geral, etc. Desse modo, o tráfego nas rodovias ${ }^{98}$ é a principal causa de poluição sonora no continente, atingindo cerca de 125 milhões de pessoas (EUROPEAN COMISSION, 2016).

A Diretiva 2002/49/EC é o principal instrumento jurídico para identificar os níveis de poluição sonora e estabelecer as medidas necessárias para o seu controle, definida pela União Europeia. Em suma, essa diretiva aplica-se para os ruídos que os humanos estão expostos, tais como em áreas com grandes aglomerações, parques urbanos, áreas naturais mais sensíveis, escolas,

\footnotetext{
${ }^{94}$ Os ramos de algumas árvores são amarrados na direção das estradas, fazendo com que cresçam na direção oposta, formando uma ponte natural.

${ }^{95}$ Cerca de 300 metros de cercas e estruturas de orientação para as espécies foram instalados, com o objetivo de guiar com segurança as espécies em direção aos túneis, bem como impedi-los de atravessar as estradas nos pontos mais perigosos. Além disso, algumas estradas foram equipadas com refletores para luzes veiculares.

${ }^{96}$ A proposta é sensibilizar a população local e turistas sobre a importância do projeto. Para isso, foram realizadas atividades recreativas e trabalhos voluntários com o público, foram instaladas placas sinalizadoras, notícias no website da Sonian Forest, revistas mensais e veículos de mídia locais, etc.

${ }^{97}$ Tais como: Natturbrug Zeepoort, Natuurbrug Duinpoort e Natuurbrug Zandpoort (nomes em holandês). Esta última já está em funcionamento e é acessível também para ciclistas, cavaleiros, pedestres e deficientes físicos.

${ }^{98}$ Para ruídos acima de $55 \mathrm{~dB}$.
} 
hospitais, etc. Além disso, existem legislações específicas para diferentes fontes de ruídos, tais como veículos a motor, equipamentos ao ar livre e outros produtos geradores de ruídos. Logo, cabe aos Estados membros da União Europeia adotarem planos de ação para o manejo de ruídos.

Nesse sentido, verifica-se que a poluição sonora vem trazendo impactos prejudiciais para todas as áreas protegidas do presente estudo, devido à proximidade destas com as áreas urbanas. De maneira geral, os funcionários dos sítios SF e PNZK buscam orientar e conscientizar os visitantes sobre os usos não permitidos dentro das áreas, dentre eles o uso de aparelhos que emitam ruídos e que possam causar perturbação, bem como existem diferentes tipos de sinalização (placas informativas, folders, banners) nas zonas de uso público.

Contudo, as principais fontes de ruídos são externas e apesar de haver procedimentos formais e legislações específicas para o controle dessa pressão, pouco tem sido feito para mitigála. Ademais, verifica-se o desenvolvimento de pesquisas científicas sobre os impactos da poluição nas espécies no sítio SF.

\section{Poluição visual}

A poluição visual ocorre quando as luzes noturnas artificiais interferem nas funções dos organismos e ecossistemas, podendo trazer graves consequências para a saúde dos seres humanos e implicações ecológicas e evolutivas para as espécies da fauna e flora (NAVARA; NELSON, 2007). Logo, verificam-se principalmente nas áreas urbanas a utilização generalizada de luzes artificiais noturnas, onde o conhecimento sobre seus efeitos adversos ainda é pouco conhecido (HÖLKER et al., 2010). Desse modo, verificam-se que todas as áreas protegidas do presente estudo sofrem com a poluição visual.

Mais recentemente, com o aumento da preocupação com à falta de energia, avanço das mudanças climáticas e as consequências socioeconômicas relacionadas, muitas regiões vêm buscando por fontes alternativas de energia, desenvolvendo novos programas e conceitos de iluminação (HÖLKER et al., 2010). No entanto, Hölker et al. (2010) ressaltam a necessidade das nações em criarem políticas de poluição visual que não se baseiem apenas na eficiência energética, mas sim visando a qualidade de vida das populações e ecossistemas afetados por esse problema.

No âmbito do continente europeu, verifica-se algumas iniciativas jurídicas relacionadas com este problema, tais como a Diretiva 2005/32/EC ${ }^{99}$, a qual estabelece requisitos e medidas

\footnotetext{
${ }^{99}$ Disponível em: <http://eur-lex.europa.eu/legal-content/EN/TXT/?uri=celex:32009R0245>. Acesso em: Abr 2016.
} 
necessárias para o uso consciente de luzes artificiais de alta intensidade e consumo de energia, visando reduzir os impactos ambientais resultantes. Nesse sentido, cabe aos Estados-membros fiscalizarem e monitorarem as fontes causadoras dessa pressão. Além disso, verificam-se algumas iniciativas para mitigação da poluição visual nas áreas protegidas do presente estudo (com exceção do sítio LM). Para o caso da SF, após pressão da gestão e da participação popular local, a agência AWV (responsável pelas estradas e tráfego de veículos), reduziu o período de exposição das luzes noturnas próximas à área protegida.

Já para o PNZK, a gestão trabalhou intensamente na comunicação (e.g. cartas informativas aos moradores, informações divulgadas no website da área protegida e distribuição de folders) com a população do entorno para a redução das luzes artificiais noturnas. Apesar da difícil possibilidade em se eliminar totalmente as luzes do entorno, a gestão recomenda e especifica a utilização de tipos de iluminação menos poluentes e agressivas ao meio ambiente. Segundo a gestão, essas ações têm sido positivas visto que os moradores vêm seguindo as recomendações propostas. Além disso, o Parque, em parceria com o governo estadual, promoveu no ano de 2016 a cerimônia de premiação intitulada "Estrela da Noite"100, criada com o objetivo de estimular a produção de melhores planos de iluminação, reduzir a poluição luminosa da região e economizar energia, com a participação dos municípios abrangentes do Parque.

\section{Transmissão de doenças entre animais selvagens}

A transmissão de doenças entre a fauna silvestre foi avaliada como uma pressão apenas para o PNZK. Ela ocorre entre as espécies de coelhos, importantes animais herbívoros pastoreadores das dunas, os quais mantém a biodiversidade desses habitats. Segundo a gestão, uma das causas possíveis pode ter sido devido ao transporte de animais e pessoas em áreas urbanas. Desse modo, essas espécies foram afastadas e vêm sendo monitoradas pela equipe do Parque. Além disso, para manter a biodiversidade das dunas, foram introduzidas novas espécies de herbívoros pastoreadores (e.g. bovinos, cavalos, bisões, cervídeos e ovelhas). A gestão alega que a população de coelhos aparentemente está se recuperando e a propagação da doença parece ter diminuído ligeiramente nos últimos cinco anos.

${ }^{100}$ Em holandês: Ster van de Nacht. 


\section{Disposição irregular de resíduos}

A disposição irregular de resíduos afeta prejudicialmente todas as áreas protegidas do presente estudo, variando em grau de intensidade. Em relação à política de resíduos da União Europeia, esta apresenta uma série de planos de ação e legislações visando reduzir os impactos negativos dos resíduos no meio ambiente e na economia, sendo a Diretiva 2008/98/EC ${ }^{101}$ o principal instrumento para o manejo de resíduos (EUROPEAN COMISSION, 2010). Essa diretiva estabelece as medidas necessárias para o tratamento de resíduos, através de técnicas adequadas de gestão, recuperação e reciclagem.

Nesse sentido, as áreas protegidas do presente estudo buscam seguir as ações de manejo estabelecidas nessa diretiva. De maneira geral, todas realizam o acondicionamento dos resíduos produzidos dentro de seus territórios em lixeiras (com aberturas menores para se evitar a retirada por parte da fauna), dispostas estratégicamente em diferentes áreas; limpeza por parte de equipe de funcionários; sistema de coleta realizado pelo serviço público dos órgãos municipais, bem como atividades de educação ambiental visando a sensibilização dos visitantes. Também são verificadas ações de fiscalização e acionamento de órgãos responsáveis para os casos de resíduos irregulares nas áreas limítrofes às áreas protegidas, bem como os resíduos recicláveis são destinados ao sistema de coleta seletiva.

Com relação à destinação de resíduos gerada pelos visitantes do sítio $\mathrm{SF}$, a gestão alega que existiam diversas lixeiras dispostas próximas as vias de acesso (por exemplo, nos estacionamentos) da área protegida, onde as pessoas frequentemente deixavam seus resíduos domésticos nesses locais públicos, evitando assim o pagamento de taxas de impostos cobrados. Assim, descartavam seus resíduos sem a necessidade de pagar, aumentando drasticamente o volume de resíduos da área protegida. Desse modo, a gestão decidiu adotar a estratégia de reduzir o elevado número de lixeiras, concentrando apenas algumas nos portões recreativos, isto é, nos locais de recreação, diminuindo assim o volume produzido de resíduos. Além disso, para o PNZK, a gestão realiza campanhas de conscientização e multirões com o apoio de grupos voluntários, visando a sensibilização dos visitantes e população do entorno.

${ }^{101}$ Waste Framework Directive. 


\section{Poluição hídrica}

A poluição hídrica foi avaliada como uma pressão e ameaça apenas para a SF, referente a frequentes contaminações das águas subterrâneas pelo uso do entorno. Segundo a gestão, a equipe exerce ações de fiscalização e monitoramento nos locais identificados como fontes de poluentes, bem como estudos científicos vêm sendo conduzidos para melhor compreender a extensão do problema e assim planejar as próximas ações a serem adotadas. Contudo, os estudos ainda estão em fase inicial, não havendo uma previsão para serem finalizados.

\section{Conflitos entre humanos e animais selvagens}

Verificam-se conflitos entre humanos e animais selvagens para todas as áreas protegidas do presente estudo, destacando-se as ocorrências de atropelamentos de algumas espécies. Logo, conforme anteriormente mencionado, todas as áreas buscaram implementar ações que visaram a conexão de habitats e passagens de fauna, evitando assim a fragmentação. Para o caso do sítio LM, verifica-se o conflito com o reaparecimento de espécies de castores, os quais vêm trazendo danos para os moradores do entorno da área protegida. Logo, a gestão procurou adotar ações de comunicação para sensibilizá-los, difundindo informações sobre como se relacionar pacificamente com essas espécies. Similarmente, o PNZK também vem adotando uma postura visando comunicar de maneira efetiva com a população, a qual em grande maioria é contra o abatimento dos cervídeos. Desse modo, a gestão, em parceria com organizações da natureza, especialistas e os órgãos municipais vem organizando reuniões públicas para explicar sobre o conflito, discutir sobre as melhores opções de resolução e dentre elas, quais as maneiras de se obter licenças para a caça desses animais. A partir dessas reuniões e da participação da sociedade, vem sendo desenvolvido um Plano de Manejo de Fauna específico para as espécies herbívoras partoreadoras do Parque.

\section{Atividades industriais}

As atividades industriais foram avaliadas como pressões e ameaças apenas para o PNZK, atividades que resultam na contaminação da atmosfera e corpos d'água pela emissão de gases poluentes, destacando-se o acúmulo de Nitrogênio. Logo, pelo fato do Nitrogênio ser um problema a nível internacional, o país possui legislações e diretivas (e.g. Diretiva de Nitratos/1991 ${ }^{102}$ e a

\footnotetext{
102 Disponível em: < http://ec.europa.eu/environment/water/water-nitrates/index_en.html>. Acesso em: Ago 2016.
} 
Diretiva de Emissões Industriais ${ }^{103}$ ou Diretiva 2010/75/EU) que devem ser seguidas pelos emissores de poluentes.

Segundo a gestão, estudos científicos vêm sendo desenvolvidos sobre os efeitos do Nitrogênio nas espécies e habitats do Parque, e já se sabe que este acúmulo prejudica o desenvolvimento de embriões de algumas espécies protegidas de pássaros. Desse modo, a gestão fez diversas manifestações através de pareceres técnicos orientando as ações de mitigação necessárias. Segundo a equipe, eles buscam ter uma boa relação com o setor industrial, o qual vem cooperando e planejando juntos com as organizações da sociedade civil sobre as ações de compensação ambiental. Dentre as ações de compensação realizadas no Parque, destacam-se ações de manejo (e.g. retirada física de camadas do solo e espécies arbustivas contaminadas em alguns hectares) e proteção (fiscalização e monitoramento).

\section{Crimes}

Verificam-se ocorrências de atividades criminais, avaliadas pelas gestões dos sítios LM e SF como pressões leves às áreas protegidas, no que se refere à segurança do local para os visitantes. De maneira geral, os crimes observados são: uso de substancias ilícitas, tráfico de drogas e atos suicidas.

Para a área protegida SF, a equipe responsável pela fiscalização atua diariamente dentro e nos limites da área protegida, e quando há ocorrências de crimes, a gestão da área alega trabalhar juntamente com as agências de polícia locais.

Já para a área protegida LM, atualmente não existe fiscalização e nenhum tipo de ação vem sendo realizada. Contudo, a gestão alega que uma das preocupações se refere aos grupos de jovens que utilizam o local para uso de substancias ilícitas. Geralmente, além do uso de drogas, os indivíduos adentram áreas sensíveis no período noturno, fazem fogueiras e dispõem resíduos de maneira irregular no local. Desse modo, a gestão vem planejando desenvolver um projeto em parceria com o município, buscando descobrir os desejos e necessidades dessas pessoas, e assim planejar algumas soluções para esses grupos, diminuindo os distúrbios ocasionados na área protegida.

${ }^{103}$ Disponível em: < http://eur-lex.europa.eu/legal-content/EN/TXT/?uri=CELEX:32010L0075>. Acesso em: Ago, 2016. 


\section{Extração de produtos não madeireiros}

A extração de produtos não madeireiros (e.g. plantas ornamentais, medicinais e espécies de cogumelos comestíveis) foram avaliadas como pressões e ameaças leves apenas pela gestão do PNZK. Segundo a gestão, diversas medidas são adotadas para conter essa pressão, tais como a presença de sinalização distribuídas pelo Parque, em especial na zona de uso público, sobre a restrição de tal atividade; a realização de atividades de educação ambiental com os grupos visitantes; informações no centro de visitantes, onde a equipe de funcionários busca sensibilizar os usuários sobre os impactos de tal atividades, bem como a presença de físcalização intensa, no interior e limites do Parque.

\section{Discussão}

O quadro 12 ilustra as principais características e observações verificadas para os quatro casos de estudos nacionais e embasa a discussão do presente capítulo. 
Quadro 12. Quadro síntese das principais características e observações referentes aos casos de estudos internacionais.

\begin{tabular}{|c|c|c|c|c|c|}
\hline \multirow{2}{*}{\multicolumn{2}{|c|}{ CARACTERÍSTICAS }} & \multicolumn{3}{|c|}{ ÁREAS PROTEGIDAS URBANAS EUROPEIAS } & \multirow{2}{*}{ OBSERVAÇÕES } \\
\hline & & LM & SF & PNZK & \\
\hline \multicolumn{2}{|c|}{ Modelo de gestão e governança } & $\begin{array}{c}\text { Órgãos municipal } \\
\text { (Departamento de Meio } \\
\text { Ambiente de Klagenfurt) e } \\
\text { estadual (Conselho Estadual } \\
\text { da Rede Natura 2000). }\end{array}$ & $\begin{array}{l}\text { Agências públicas (Flemish } \\
\text { Agency for Nature and Forests - } \\
\text { ANB -, Bruxelles Environnement } \\
\text { - IBGE - e Direction de la } \\
\text { Nature et des Forêts - DNF). }\end{array}$ & $\begin{array}{l}\text { Órgãos municipais (Velsen, Bloemendaal, } \\
\text { Haarlem e Zandvoort) e estadual } \\
\text { (Província da Holanda do Norte), } \\
\text { autoridades provinciais de águas (PWN), } \\
\text { Sociedade para Conservação de } \\
\text { Monumentos Naturais, Sociedade para a } \\
\text { Natureza e Educação Ambiental (IVN), } \\
\text { Comissão Florestal (SBB) e proprietários } \\
\text { privados. }\end{array}$ & $\begin{array}{l}\text { Órgãos governamentais e não } \\
\text { governamentais (e.g. ONGs e } \\
\text { entidades privadas) detêm a } \\
\text { autoridade e responsabilidade geral } \\
\text { pela gestão das UCs, determinando } \\
\text { as principais decisões de gestão que } \\
\text { afetam a área protegida. Maior } \\
\text { flexibilidade, autonomia e } \\
\text { especialização. }\end{array}$ \\
\hline \multirow[t]{4}{*}{$\begin{array}{l}\text { Recursos } \\
\text { financeiros }\end{array}$} & Dos últimos 5 anos & $\begin{array}{l}\text { A área protegida é financiada } \\
\text { pelo município e pela } \\
\text { administração estadual } \\
\text { competente, bem como } \\
\text { recebe recursos financeiros } \\
\text { esporádicos referentes à } \\
\text { compensações ambientais e } \\
\text { instituições privadas. }\end{array}$ & $\begin{array}{c}\text { O sítio SF recebe recursos } \\
\text { financeiros dos governos } \\
\text { municipais e estadual, bem como } \\
\text { por associações do setor público } \\
\text { e privado, que buscam promover } \\
\text { a conservação do meio ambiente. }\end{array}$ & $\begin{array}{c}\text { Recebe recursos do Ministério da } \\
\text { Agricultura, Natureza e Qualidade } \\
\text { Alimentar e de organizações para a } \\
\text { conservação da natureza (públicas e } \\
\text { privadas) }\end{array}$ & \multirow{4}{*}{$\begin{array}{l}\text { De maneira geral, as equipes de } \\
\text { gestão vêm buscando novas fontes } \\
\text { de recursos e maior suporte para a } \\
\text { conservação da área, tanto nos } \\
\text { setores públicos como privados. } \\
\text { Contudo, apesar da maior } \\
\text { diversificação de fontes de recursos, } \\
\text { não há perspectivas financeiras } \\
\text { estáveis a longo prazo. }\end{array}$} \\
\hline & & \multicolumn{3}{|c|}{ Suficientes } & \\
\hline & Dos próximos 5 anos & \multicolumn{3}{|c|}{$\begin{array}{l}\text { As equipes de gestão não apresentam uma opinião formada se os recursos financeiros serão suficientes para a } \\
\text { realização de ações de manejo críticas. }\end{array}$} & \\
\hline & $\frac{\text { Possibilidade de }}{\text { concessões }}$ & \multicolumn{3}{|c|}{ Sim } & \\
\hline
\end{tabular}

Fonte: Elaborado pela autora (2016). 


\begin{tabular}{|c|c|c|c|c|}
\hline \multirow{2}{*}{ CARACTERÍSTICAS } & \multicolumn{3}{|c|}{ ÁREAS PROTEGIDAS URBANAS EUROPEIAS } & \multirow{2}{*}{ OBSERVAÇÕES } \\
\hline & LM & SF & PNZK & \\
\hline Recursos humanos & \multicolumn{2}{|l|}{ Insuficientes } & Suficientes & $\begin{array}{l}\text { Foram considerados insuficientes pelas equipes de gestão, } \\
\text { com exceção do PNZK. }\end{array}$ \\
\hline \multirow[t]{2}{*}{ Participação da sociedade civil } & \multicolumn{3}{|c|}{$\begin{array}{l}\text { Reuniões promovidas pelos Conselhos Consultivos e participação nas discussões de } \\
\text { políticas ambientais e territoriais que envolvam os sítios. Os Conselhos são formados } \\
\text { por membros da sociedade civil (e.g. ONGs, universidades, instituições privadas), } \\
\text { políticos, especialistas diversos, os quais se reunem periodicamente para discutir o } \\
\text { processo de tomada de decisão da área protegida, bem como supervisionam } \\
\text { conjuntamente as atividades. }\end{array}$} & \multirow[t]{2}{*}{$\begin{array}{l}\text { Consideram como fundamental que a população do entorno } \\
\text { e visitantes apoiem os seus objetivos, bem como fomentam a } \\
\text { participação de voluntários e grupos de apoio diversos. }\end{array}$} \\
\hline & \multicolumn{3}{|c|}{$\begin{array}{c}\text { Engajamento do público no desenvolvimento de projetos e atividades educativas, } \\
\text { formando um grande grupo de voluntarios que auxiliam em diversas ações dos } \\
\text { programas de manejo da área. Além disso, possuem diversos parceiros (instituições } \\
\text { privadas e organizações da sociedade civil) }\end{array}$} & \\
\hline \multirow[t]{2}{*}{$\begin{array}{l}\text { Estratégias de comunicação e } \\
\text { divulgação das informações } \\
\text { relacionadas às UCs }\end{array}$} & \multirow[t]{2}{*}{$\begin{array}{l}\text { Para a divulgação das principais } \\
\text { informações, noticias, eventos e } \\
\text { atividades relacionadas ao sítio, } \\
\text { utiliza-se os veículos de mídia } \\
\text { local (jornais, rádio e TV) e mídias } \\
\text { sociais. }\end{array}$} & \multicolumn{2}{|c|}{$\begin{array}{l}\text { Diferentes estratégias de comunicação vêm sendo } \\
\text { criadas, como a criação de folders e cartilhas de } \\
\text { informações (atualizada todos os anos), um } \\
\text { website oficial interativo, revistas eletrônicas } \\
\text { bianuais e boletins eletrônicos, todos produzidos } \\
\text { em diferentes línguas (inglês, francês, holandês e } \\
\text { alemão). }\end{array}$} & \multirow[t]{2}{*}{$\begin{array}{l}\text { As equipes de gestão almejam por uma identidade } \\
\text { corporativa forte e reconhecível pelo público.As estratégias } \\
\text { de comunicação têm sido bem sucedidas, onde os visitantes } \\
\text { podem encontrar todas as informações importantes em fáceis } \\
\text { plataformas informativas e ilustrativas. Além disso, todos os } \\
\text { eventos, atividades e cursos são promovidos nesses veículos. }\end{array}$} \\
\hline & & - & $\begin{array}{l}\text { Criação de um aplicativo para } \\
\text { celulares, contendo diversas } \\
\text { informações para os visitantes. }\end{array}$ & \\
\hline
\end{tabular}

Fonte: Elaborado pela autora (2016). 
Os três casos de estudos apresentados no presente Capítulo mostraram-se ser típicas áreas protegidas pressionadas e ameaçadas pelo desenvolvimento urbano local, bem como possuem grande importância para seus territórios, devido aos inúmeros serviços ecossistêmicos fornecidos, por conservarem a biodiversidade e pelo grande potencial educacional, científico, turístico e recreativo. Essas áreas são utilizadas pela população urbana de diversas maneiras, estando constantemente suscetíveis à ocorrência de atividades ilegais, similarmente aos casos de estudo apresentado por Trzyna (2014).

No presente capítulo, são avaliadas as principais pressões e ameaças de três áreas protegidas urbanas do continente europeu, bem como são analisadas as principais ações de conservação adotadas visando a sua mitigação. Logo, verifica-se que todas as áreas protegidas apresentaram sofrer impactos prejudiciais referentes às seguintes pressões: presença de espécies exóticas invasoras; desenvolvimento urbano; turismo e recreação; estradas, rodovias e ferrovias; disposição irregular de resíduos; conflitos entre humanos e animais selvagens; poluição sonora e visual. Esses resultados validam os estudos de alguns autores (e.g. TERBORGH et al., 2002; ERVIN, 2003; NCHOR; UGOGO, 2012; FONTOURA; MEDEIROS; ADAMS, 2016), os quais identificam diversas pressões e ameaças para áreas protegidas nacionais e internacionais. Além disso, verificase junto às gestões que essas pressões poderão continuar a ocorrer nos próximos cinco anos, variando em grau de intensidade. Nesse período, observa-se que outras ameaças poderão trazer novos impactos significativos para esses locais, tais como os eventos relacionados às mudanças climáticas e a poluição atmosférica. Desse modo, mesmo em países desenvolvidos, áreas protegidas enfrentam pressões e ameaças constantes, corroborando com alguns autores (e.g. CAREY; DUDLEY; STOLTON, 2000; WORBOYS; TRZYNA, 2015).

Das pressões e ameaças comuns aos três casos de estudos, observa-se que o desenvolvimento urbano é aquele que as afeta com maior grau de intensidade, seguido das espécies exóticas invasoras, turismo e recreação e a presença de infraestruturas lineares. No entanto, conforme observado por Mathur, Onial e Mauvais (2015), as pressões e ameaças apresentam naturezas diversas, e o que pode ser uma pressão em um local, pode não ser visto como tal para outra área protegida, ou pode evoluir através do tempo e se tornar uma ameaça. Logo, cada caso de estudo revela necessidades distintas para as gestões priorizarem aquelas mais urgentes. Como por exemplo, para a área SF, verifica-se que as pressões mais severas, isto é, aquelas que necessitam de maior atenção são: o desenvolvimento urbano; turismo e recreação; espécies exóticas invasoras; 
estradas e rodovia; poluição atmosférica; poluição sonora e visual. Já para o sítio LM, são as espécies exóticas invasoras, o desenvolvimento urbano e a caça no seu território. Em relação ao PNZK, as prioridades da gestão devem focar para as espécies exóticas invasoras; poluição atmosférica; desenvolvimento urbano; transmissão de doenças; turismo e recreação; estradas e rodovia.

Verificam-se que os três casos de estudo buscaram adotar uma série de ações de conservação. Logo, de maneira similar ao Capítulo II, as ações são organizadas e estruturadas em categorias $^{104}$, de acordo com as suas diferentes finalidades ${ }^{105}$ (proteção, manejo, operacionalização, integração, uso público e conhecimento), a fim de se obter uma melhor compreensão sobre as diferentes iniciativas (quadro 13). Assim, verifica-se que a essa organização é subjetiva, visto que algumas iniciativas listadas podem também se enquadrar em outras categorias, e se inter-relacionar. Além disso, ressalta-se que todas as iniciativas listadas neste quadro foram aquelas relatadas pelos respectivos gestores, podendo haver outras ações que não foram comentadas durante as entrevistas.

${ }^{104}$ As categorias foram baseadas nos temas dos Programas de Manejo, sugeridos na revisão do Roteiro Metodológico de Planejamento das UCs de proteção integral (FERNANDES; HANGAE; MOTA, 2011), já previamente detalhadas no Capítulo 2.

${ }^{105}$ As finalidades de cada categoria são descritas detalhadamente no Capítulo 2. 
Quadro 13. Quadro síntese das ações de conservação identificadas para os Sítios Natura 2000 Lendspitz-Maiernigg, Sonian Forest e Parque Nacional ZuidKennemerland, distribuídas em categorias e subcategorias, segundo as suas finalidades. Legenda: o símbolo " $\sqrt{ }$ " representa que a UC adotou a iniciativa; nenhum símbolo representa que a UC não relatou a adoção da iniciativa durante a entrevista; o símbolo "_" significa que a iniciativa não foi adotada pois não condiz com os objetivos da UC.

\begin{tabular}{|c|c|c|c|c|c|}
\hline CATEGORIAS & SUBCATEGORIAS & $\begin{array}{l}\text { INICIATIVAS } \\
\end{array}$ & $\mathbf{L M}$ & SF & PNZK \\
\hline \multirow{4}{*}{ PROTEÇÃO } & \multirow{4}{*}{ Fiscalização } & $\begin{array}{l}\text { Manifestar através de pareceres técnicos: orientações, restrições e permissões para } \\
\text { planos e projetos gerais, que possam trazer impactos prejudiciais significativos à área } \\
\text { protegida. }\end{array}$ & $\sqrt{ }$ & $\sqrt{ }$ & $\sqrt{ }$ \\
\hline & & Fiscalizar e monitorar o território e seus limites. & & $\sqrt{ }$ & $\sqrt{ }$ \\
\hline & & Acionar agências locais ou regionais quando necessário. & $\sqrt{ }$ & $\sqrt{ }$ & $\sqrt{ }$ \\
\hline & & $\begin{array}{l}\text { Fiscalizar e notificar os indivíduos pegos em atividades contrárias aos objetivos de } \\
\text { conservação da área. }\end{array}$ & $\sqrt{ }$ & $\sqrt{ }$ & $\sqrt{ }$ \\
\hline \multirow{10}{*}{ MANEJO } & \multirow{7}{*}{ Habitats } & Promover conexões com outras áreas naturais. & $\sqrt{ }$ & $\sqrt{ }$ & $\sqrt{ }$ \\
\hline & & $\begin{array}{l}\text { Fomentar e orientar os responsáveis a implementar medidas gerais de compensação } \\
\text { ambiental (e.g. criação de infraestruturas verdes para trânsito de animais silvestres e } \\
\text { conexões de habitats), em parceria com instituições públicas e privadas, organizações de } \\
\text { conservação da natureza e sociedade civil. }\end{array}$ & $\sqrt{ }$ & $\sqrt{ }$ & $\sqrt{ }$ \\
\hline & & Estimular a incorporação de elementos naturais no ambiente urbano do entorno. & & $\sqrt{ }$ & $\sqrt{ }$ \\
\hline & & $\begin{array}{l}\text { Promover ações de manejo visando o restabelecimento dos processos naturais (e.g. } \\
\text { manejo das dunas para conter o avanço do nível do mar). }\end{array}$ & & $\sqrt{ }$ & $\sqrt{ }$ \\
\hline & & $\begin{array}{l}\text { Evitar resíduos (e.g. acondicioná-los em lixeiras, destiná-los ao sistema de coleta } \\
\text { público, concentrar o número de lixeiras nas zonas de uso público). }\end{array}$ & $\sqrt{ }$ & $\sqrt{ }$ & $\sqrt{ }$ \\
\hline & & Recuperar áreas degradadas. & $\sqrt{ }$ & $\sqrt{ }$ & $\sqrt{ }$ \\
\hline & & Fomentar a reutilização e recicláveis dos resíduos. & $\sqrt{ }$ & $\sqrt{ }$ & $\sqrt{ }$ \\
\hline & \multirow{3}{*}{ Espécies } & $\begin{array}{l}\text { Promover o enriquecimento da biodiversidade (e.g. introdução de novas espécies de } \\
\text { flora em zonas vulneráveis). }\end{array}$ & & $\sqrt{ }$ & \\
\hline & & $\begin{array}{l}\text { Detectar, prevenir, erradicar e/ou confinar espécies exóticas invasoras, com auxílio de } \\
\text { grupos de apoio, voluntários e outras tecnologias (Sistema de Alerta Precoce e de } \\
\text { Informação - DAISE). }\end{array}$ & $\sqrt{ }$ & $\sqrt{ }$ & $\sqrt{ }$ \\
\hline & & $\begin{array}{l}\text { Evitar a transmissão de doenças entre a fauna silvestre (e.g. afastar as espécies } \\
\text { contaminadas por patógenos das demais). }\end{array}$ & - & - & $\sqrt{ }$ \\
\hline \multirow{4}{*}{ OPERACIONALIZAÇÃO } & $\begin{array}{l}\text { Cooperação } \\
\text { interinstitucional }\end{array}$ & $\begin{array}{l}\text { Articular com diferentes instituições: acompanhar e participar de discussões de políticas } \\
\text { ambientais, planos territoriais, etc. }\end{array}$ & $\sqrt{ }$ & $\sqrt{ }$ & $\sqrt{ }$ \\
\hline & \multirow{3}{*}{$\begin{array}{l}\text { Infraestrutura e } \\
\text { equipamentos }\end{array}$} & $\begin{array}{l}\text { Sinalizar o interior e entorno da área protegida (e.g. distribuição de placas, folders e } \\
\text { banners informativos). }\end{array}$ & $\sqrt{ }$ & $\sqrt{ }$ & $\sqrt{ }$ \\
\hline & & Criar facilidades para os visitantes & $\sqrt{ }$ & $\sqrt{ }$ & $\sqrt{ }$ \\
\hline & & Capacitar os funcionários (e.g. para atividades de educação ambiental e manejo) & $\sqrt{ }$ & $\sqrt{ }$ & $\sqrt{ }$ \\
\hline
\end{tabular}




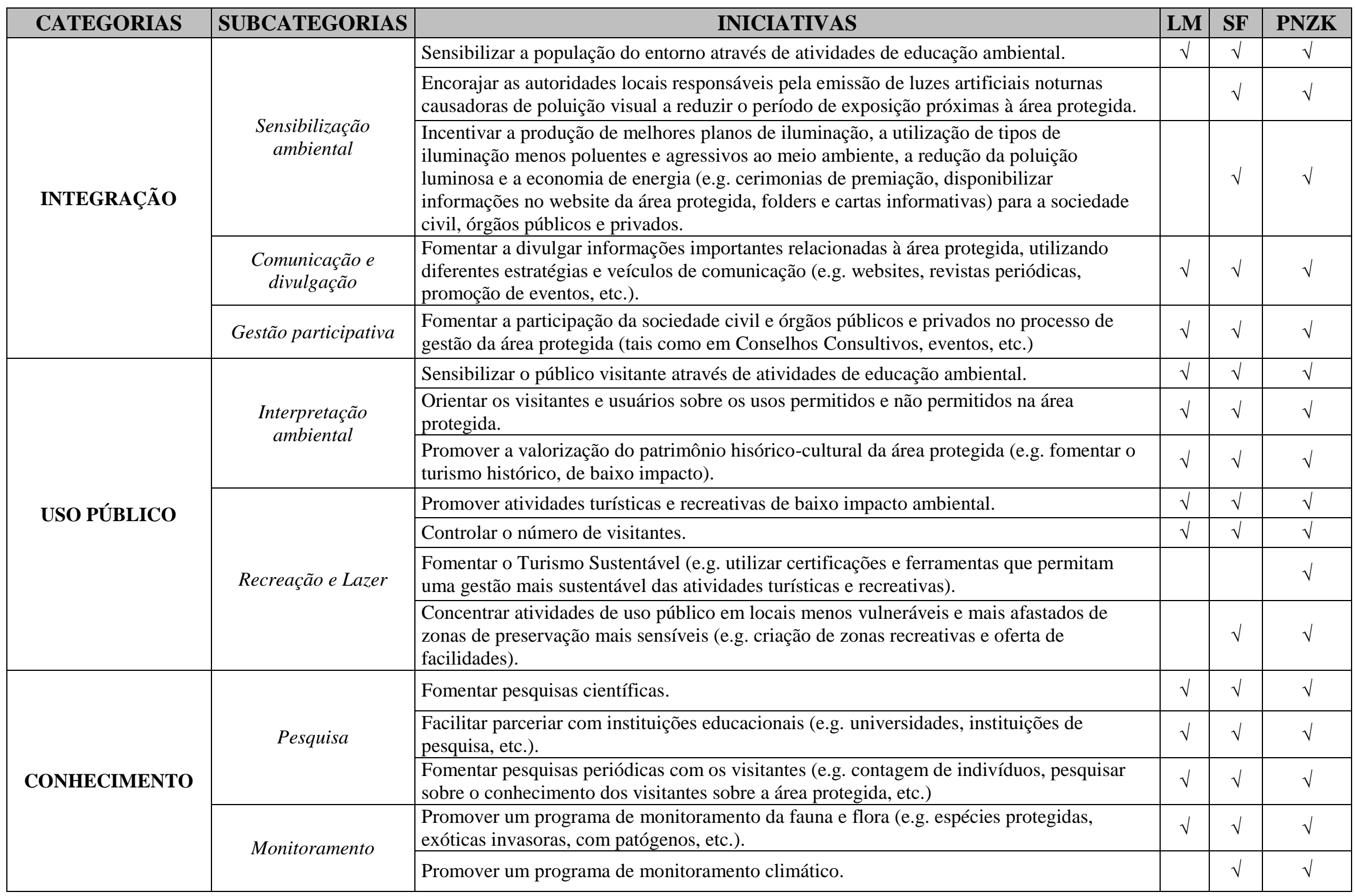

Fonte: Elaborada pela autora (2016). 
As ações de proteção visam preservar os recursos da área protegida de atividades que possam vir a comprometer a integridade dos seus patrimônios. Desse modo, a única área que demonstrou problemas em relação à fiscalização do seu território foi o sítio LM, o qual não possui funcionários para esse fim.

As ações de manejo têm como objetivo manter os habitats e espécies protegidos, utilizando técnicas instrumentais. Das ações observadas, verifica-se uma grande preocupação da gestão e altos investimentos na promoção de conectividade entre os diferentes habitats, reduzindo os efeitos da fragmentação causada pelo ambiente urbano, aumentando assim as chances de sobrevivência das espécies. No entanto, as gestões alegam que essas ações só foram possíveis devido ao grande envolvimento da sociedade civil e suporte de diferentes organizações (públicas e privadas) e órgãos municipais. Essas evidências ressaltam os fatos advertidos por Trzyna (2007), onde alianças e parcerias são fundamentais para que as ações de conservação se concretizem, principalmente para as áreas protegidas que estão sob pressão da urbanização. Além disso, no âmbito das ações de manejo, verifica-se que as gestões vêm adotando ações com o objetivo de fortalecer as áreas protegidas frente às mudanças climáticas, ressaltando visões de planejamento a longo prazo.

As ações de operacionalização possuem como finalidade a manutenção das funções operacionais da área protegida (e.g. infraestrutura, equipamentos, recursos humanos) e o fortalecimento das relações interinstitucionais que envolvem direta ou indiretamente essas áreas. Nesse sentido, Guimarães e Pellin (2015) apontam ser fundamental as áreas protegidas urbanas estarem integradas com o seu entorno. Desse modo, observa-se nos casos de estudo altos investimentos e esforços para melhorar os diversos tipos de infraestruturas para o público visitante, bem como a formação de diferentes tipos de parcerias, fomentando oportunidades para o desenvolvimento local.

Também é verificado para todos os casos de estudos a adoção de ações de integração, as quais visam fortalecer as relações da população local com as áreas protegidas e a sensibilização ambiental, a fim de se desenvolver e aumentar a consciência crítica sobre a problemática ambiental. Conforme alegam Guimarães e Pellin (2015), programas de educação ambiental e patrimonial visam principalmente aumentar a participação social na proteção dessas áreas, bem como oferecem oportunidades para que os indivíduos desfrutem do contato com o meio natural, resultando em qualidade de vida. As experiências e vivências com a natureza são transformadoras e proporcionam oportunidades para o desenvolvimento da consciência conservacionista (MENDONÇA, 2007). 
Para tanto, além das estratégias de comunicação tradicionais (tais como a divulgação de informações básicas pelos veículos de mídia locais), são utilizados meios ilustrativos (e.g. uso de vídeos, mídias sociais, aplicativos, websites próprios e revistas periódicas) para diferentes tipos de públicos, buscando promover a visibilidade das áreas. De maneira geral, essas ações buscaram fomentar gestões mais participativas e menos centralizadas, através da mobilização e empoderamento de representantes das comunidades do entorno nos processos decisórios das áreas protegidas.

Observa-se que as áreas protegidas do presente estudo apresentam importância biológica, histórica e cultural para seus territórios. Nesse sentido, com o objetivo de valorizar a importância desse patrimônio, ordenar, direcionar e orientar o uso das áreas protegidas pelos visitantes, algumas iniciativas são adotadas, tais como o uso de ferramentas que permitam uma gestão mais sustentável das atividades turísticas e recreativas, bem como a restauração e incorporação de monumentos históricos como atratividades turísticas. Ademais, observa-se para dois casos de estudo a concentração de atividades de uso público em locais menos vulneráveis e mais afastados de zonas de preservação mais sensíveis, através da criação de zonas recreativas e oferta de facilidades próximas às essas para os visitantes. Este conjunto de estratégias, além de facilitar o acesso do público e estimular a visitação, representa uma grande oportunidade para um maior contato e sensibilização da população local.

As ações de conhecimento proporcionam subsídios para a proteção e o manejo dos recursos naturais, estando relacionadas aos estudos, pesquisas científicas e ao monitoramento ambiental a serem desenvolvidos na área protegida. Segundo Guimarães e Pellin (2015), o conhecimento produzido nessas áreas deve servir de base para o planejamento dos programas de ações de uma área protegida. Logo, verificam-se para os casos de estudo do presente capítulo diversas iniciativas fomentando a pesquisa científica para problemas ainda não resolvidos. Além disso, também se observa a cooperação com instituições educacionais diversas, aumentando as oportunidades de produção de conhecimento. De maneira geral, não foram verificados problemas no relacionamento das gestões com os pesquisadores.

Os planos de manejo dos casos de estudos seguem as orientações propostas pela IUCN e pela Rede Natura 2000, as quais priorizam um processo de gestão dinâmico, adaptativo e participativo. Desse modo, observa-se que estes instrumentos, regidos por diretrizes que visam uma gestão adequada, apresentam uma visão a longo prazo, para 10 a 20 anos. Como por exemplo, a 
gestão do sítio SF, através do Structural Visual Project, pautou os seus programas de ação levando em consideração como a área protegida deve ser vista no futuro. Além disso, a gestão do sítio LM implementou o projeto City Meets Nature, de longa duração e com objetivos de aproximar a população com a área protegida, criando mais oportunidades de conservação e integração da área com a cidade.

Em relação aos recursos humanos dos casos de estudos, verificam-se que estes foram considerados suficientes para uma gestão efetiva apenas no PNZK. As demais gestões alegam ser insuficientes para o atendimento das demandas atuais, e especificamente para o sítio LM, a situação é ainda mais agravante, devido a inexistência de funcionários próprios.

No que concerne os recursos financeiros das áreas protegidas, Guimarães e Pellin (2015) ressaltam que quando apropriados, podem auxiliar na mitigação das pressões e ameaças, bem como aumentar os seus benefícios. Nesse sentido, observa-se que as três áreas protegidas urbanas buscaram utilizar diferentes fontes de recursos, seja através de parcerias privadas, recursos provenientes de compensação ambiental e ou de órgãos públicos (governos estaduais e municipais). Desse modo, as gestões advertem que os recursos financeiros dos últimos cinco anos têm sido adequados para a execução dos programas de ações. No entanto, alegam que não há previsão financeira estável a longo prazo. Assim, frente a um cenário futuro de incertezas, a busca por fontes de recursos diferenciadas se torna uma opção plausível para as áreas protegidas.

\section{Considerações Finais}

As análises referentes aos três casos de estudos mostraram uma variedade de pressões e ameaças, tais como: espécies exóticas invasoras, desenvolvimento urbano, caça, turismo e recreação, mudanças climáticas, pesca, estradas, rodovias e ferrovias; disposição irregular de resíduos; conflitos entre humanos e animais selvagens; poluição sonora; poluição visual; crimes; poluição atmosférica; transmissão de doenças entre animais silvestres; atividades industriais; extração de produtos não madeireiros e poluição hídrica.

Para mitigar essas pressões e ameaças, as gestões adotam uma série de iniciativas, tais como ações de conservação que visam a proteção (e.g. fiscalização do território) e o manejo dos recursos naturais (e.g. promoção de conexões com outros habitats), a operacionalização (e.g. infraestrutura e equipamentos para visitantes), integração com o entorno (e.g. programas de educação ambiental visando a sensibilização), bem como ações voltadas para o uso público (e.g. criação de infraestrutura para visitantes) e produção de conhecimento (e.g. fomento à pesquisa científica). 
Das ações implementadas, destacam-se algumas iniciativas inovadoras: a implementação do projeto City Meets Nature (sítio LM), o qual vem buscando compatibilizar a conservação da área protegida com a presença da cidade, bem como o Structural Visual Project (sítio SF), que visa o fortalecimento da imagem da área protegida para a comunidade do entorno. Logo, além das ações típicas de manejo, indispensáveis para a manutenção de espécies e habitats, as áreas protegidas do presente capítulo articularam com parcerias estratégicas, avançando na integração com o seu entorno.

Nesse sentido, apesar de cada área protegida apresentar particularidades e realidades distintas, as áreas protegidas mostraram seguir uma gestão participativa, adotando abordagens visando a integração e comunicação com a população urbana. Desse modo, esses resultados evidenciam que a participação da comunidade é fundamental para o cumprimento dos objetivos econômicos, sociais e ambientais que suportam a conservação das áreas protegidas. Por fim, a diversificação de fontes de financiamento mostrou-se adequada para a adoção de ações de conservação fundamentais para a gestão das áreas protegidas, frente aos cenários econômicos futuros incertos. 


\section{CAPÍTULO IV. ORIENTAÇÕES E MELHORES PRÁticAS PARA ÁREAS PROTEGIDAS URBANAS}

\section{Introdução}

Sabe-se que as áreas protegidas em geral representam uma contribuição essencial para a manutenção da saúde e bem-estar dos organismos e ecossistemas globais (WORBOYS et al., 2015). Já as áreas protegidas inseridas ou localizadas próximas às áreas urbanas contribuem em especial para a qualidade de vida do ambiente urbano, para a manutenção da biodiversidade, fornecem oportunidades para recreação, interação social, educação e serviços ecossistêmicos fundamentais para a vida no ambiente terrestre (SUNDSETH; RAEYMAEKERS, 2006; TRZYNA, 2014; GUIMARÃES; PELLIN, 2015; WORBOYS; TRZYNA, 2015).

Não obstante, observa-se que a conservação da biodiversidade e a gestão das áreas protegidas urbanas podem ser mais dificultosas e complexas do que nas áreas protegidas localizadas em zonas mais remotas (SUNDSETH; RAEYMAEKERS, 2006; TRZYNA, 2015). Isso ocorre devido às áreas urbanas serem locais muito mais dinâmicos, abrigando uma intensidade de processos, desenvolvimentos e fluxos de pessoas (SUNDSETH; RAEYMAEKERS, 2006) e, consequentemente, ocasionando em impactos e desafios para as áreas naturais.

Desse modo, Sandwith $(2015)^{106}$ alega que os maiores desafios para as áreas protegidas urbanas do século XXI são internos e externos. Os desafios internos são diversos, tais como ausência de leis efetivas, recursos humanos e financeiros, infraestrutura, treinamento, planos de manejo, apoio às comunidades locais, baixa compreensão da sociedade em geral sobre os problemas de conservação, entre outros. Como resultado, Sandwith (2015) adverte que pelo menos metade de todas as áreas protegidas do mundo não possuem capacidade de gestão adequada, o que contribui para o declínio da qualidade desses locais.

Já os desafios externos são aqueles que causam impactos imediatos nas áreas protegidas, com base no contexto em que se encontram, como o uso do solo inapropriado no entorno desses locais (e.g. atividades industriais e mineração) e problemas de governança (e.g. falta de vontade política para incorporar a biodiversidade na agenda política) (SANDWITH, 2015). Esses fatos podem ser encontrados em alguns estudos (e.g. SUNDSETH; RAEYMAEKERS, 2006; TRZYNA, 2015; GUIMARÃES; PELLIN, 2015).

\footnotetext{
${ }^{106}$ Informação fornecida por Trevor Sandwith, diretor do Programa Global de Áreas Protegidas da IUCN, durante uma visita técnica da autora à sede da organização em Gland (Suíça), em 2015.
} 
Nesse sentido, como as gestões responsáveis pelas áreas protegidas urbanas podem conciliar a conservação da biodiversidade com o desenvolvimento urbano? Quais iniciativas devem ser adotadas durante o processo de gestão e governança para que estas cumpram com os seus objetivos? Como impedir que as áreas protegidas urbanas se tornem "ilhas", ou também "fósseis vivos" (impedindo o fluxo gênico entre as espécies, podendo resultar em extinção), visto os diversos desafios verificados nas áreas urbanas?

Para responder essas questões, são analisadas as orientações e melhores práticas em áreas protegidas urbanas, propostas pela IUCN, uma das principais autoridades globais, responsável por elaborar diretrizes para as áreas protegidas mundiais, as quais seguem as recomendações atuais da CDB. Além disso, busca-se identificar as principais variáveis que interferem no alcance dos seus objetivos.

A IUCN é responsável por desenvolver uma série de publicações referentes às questões que envolvem as áreas protegidas mundiais. Dentre elas, destacam-se aquelas responsáveis por fornecer orientações gerais para um processo de gestão efetivo, processos de avaliação de efetividade nessas áreas (e.g. THOMAS; MIDDLETON, 2003; HOCKINGS et al., 2006; LOCKWOOD, M.; WORBOYS, G. L.; KOTHARI, 2006; LEVERINGTON et al., 2010a; WORBOYS et al., 2015) e especificamente publicações que tratam de áreas protegidas urbanas (e.g. TRZYNA, 2005, 2007, 2014).

Desse modo, para analisar as orientações ${ }^{107}$ e melhores práticas em áreas protegidas urbanas, foram consultadas como referências todas as publicações citadas anteriormente, com foco em especial nas referências internacionais mais atuais, tais como os documentos intitulados: Urban Protected Areas: profiles and best practice guidelines (TRZYNA, 2014) e Protected Area Governance and Management ${ }^{108}$ (WORBOYS et al., 2015). Assim, a partir dessas referências, busca-se analisar e ressaltar as principais orientações e melhores práticas para que as áreas protegidas urbanas cumpram com seus objetivos de conservação e enfrentem os seus diversos

\footnotetext{
107 Observam-se sistemas de áreas protegidas de diferentes países que utilizam como base as orientações da IUCN para formular suas diretrizes e recomendações próprias, segundo as particularidades de cada local. Como por exemplo, observam-se no Brasil diversos roteiros metodológicos para diferentes tipos de áreas protegidas e esferas administrativas (e.g. GALANTE; BESERRA; MENEZES, 2002; GONÇALVEZ et al. (2009); FERNANDES; HANGAE; MOTA, 2011; SOUZA; VIEIRA; SILVA, 2015). Na Europa, verificam-se orientações para a gestão em áreas protegidas de diversas redes, tais como as pertencentes à Rede Natura 2000 (e.g. EUROPEAN COMISSION, 2000; EUROPEAN COMISSION, 2014).

${ }^{108}$ Este documento fornece orientações gerais para todos os tipos de áreas protegidas. Logo, para a análise dessas orientações, o presente capítulo busca trazê-las para o contexto das áreas protegidas urbanas.
} 
desafios. A partir das análises sobre as orientações propostas, busca-se discutir sobre algumas considerações referentes aos casos de estudos nacionais (Capítulo II) e internacionais (Capítulo III).

\section{Orientações e melhores práticas propostas pela IUCN}

A IUCN fornece uma série de orientações e melhores práticas consideradas fundamentais para as áreas protegidas em geral. Visto o vasto campo de conhecimento adquirido nesta temática e, sem a pretensão de esgotar o assunto, o presente capítulo discute sobre as principais considerações a respeito de dois componentes fundamentais que sustentam essas áreas: governança e gestão. Assim, entende-se que as áreas protegidas urbanas devem ser sustentadas por práticas de governança e gestão adequadas, para que atinjam os seus objetivos de conservação. Logo, são discutidas as orientações e melhores práticas para que esses dois componentes apresentem qualidade.

\subsection{Governança em Áreas Protegidas Urbanas}

De maneira geral, verificam-se que os territórios terrestres e marinhos são divididos em diversas unidades administrativas, os quais são governados pelos tomadores de decisão, com o auxílio de especialistas e da participação da sociedade (BORRINI-FEYERABEND; HILL, 2015). As decisões políticas a serem adotadas nesses territórios são baseadas na forma como os líderes enxergam a paisagem e se estes levam em consideração princípios referentes à conservação dos atributos ecológicos, culturais e à sustentabilidade desses locais (BORRINI-FEYERABEND; HILL, 2015). Logo, a governança atual da conservação do meio ambiente é sustentada pelos compromissos firmados por essas lideranças (BORRINI-FEYERABEND; HILL, 2015).

A definição para governança utilizada pela IUCN pode ser traduzida como "a interação entre estruturas, processos e tradições que determinam como o poder e as responsabilidades são exercidas, como as decisões são tomadas e como os cidadãos ou outras partes interessadas podem participar"109 (GRAHAM, J.; AMOS, B.; PLUMPTRE, 2003, p.2, tradução nossa). Desse modo, de maneira geral, a governança refere-se aos princípios, políticas e normas relativas ao processo de tomada de decisão em áreas protegidas.

109 "Governance is the interactions among structures, processes and traditions that determine how power and responsibilities are exercised, how decisions are taken, and how citizens or other stakeholders have their say". GRAHAM, J.; AMOS, B.; PLUMPTRE, 2003, p.2). 
Nesse sentido, os governantes são responsáveis por estabelecer um sistema jurídico de um país, com instrumentos legais e ferramentas operacionais (e.g. diretrizes, legislações, regulamentos, decretos, etc.), visando mediar interesses e conflitos por meio da gestão ambiental pública (BORRINI-FEYERABEND; HILL, 2015), devendo prevalecer os interesses coletivos da sociedade. Em suma, são eles que definem a política ambiental de um país.

De acordo com a IUCN, existem quatro modelos de governança para as áreas protegidas, sintetizadas no quadro 14.

Quadro 14. Tipos de governança e suas características, de acordo com a IUCN.

\begin{tabular}{|c|l|}
\hline TIPOS DE GOVERNANÇA & \multicolumn{1}{|c|}{ CARACTERÍSTICAS } \\
\hline Governança centralizada no governo & $\begin{array}{l}\text { Órgãos governamentais detêm a autoridade e responsabilidade geral pela } \\
\text { gestão de uma área protegida. Eles determinam os seus objetivos de } \\
\text { conservação, desenvolvem e aplicam o seu plano de manejo. }\end{array}$ \\
\hline Governança compartilhada & $\begin{array}{l}\text { É baseada em mecanismos e processos institucionais pelos quais a } \\
\text { autoridade e a responsabilidade são compartilhadas entre dois ou mais } \\
\text { atores (governamentais e não governamentais). }\end{array}$ \\
\hline Governança privada & $\begin{array}{l}\text { A autoridade e responsabilidade pela gestão da área protegida cabe aos } \\
\text { proprietários (e.g. indivíduos, cooperativas, ONGs ou empresas), que } \\
\text { determinam os objetivos de conservação e as regras a serem respeitadas. }\end{array}$ \\
\hline Governança pelas comunidades locais & $\begin{array}{l}\text { Áreas protegidas governadas e administradas coletivamente por uma } \\
\text { comunidade de pessoas. }\end{array}$ \\
\hline
\end{tabular}

Fonte: Elaborado pela autora (2016), a partir de Borrini-Feyerabend e Hill (2015).

Independentemente do tipo de governança, a Convenção da Diversidade Biológica (CDB) e o Programa de Trabalho sobre Áreas Protegidas (PoWPA) ressaltam a necessidade de estimular as autoridades responsáveis pelas áreas protegidas a melhorarem a qualidade da governança (BORRINI-FEYERABEND; HILL, 2015). Pensando nisso, a IUCN estabeleceu princípios gerais de boa governança que sejam aplicáveis numa variedade de circunstâncias e situações (quadro 15) (BORRINI-FEYERABEND; HILL, 2015), bem como desenvolveu métodos para avaliações de governança (BORRINI-FEYERABEND et al., 2013). 
Quadro 15. Princípios e considerações gerais de boa governança em áreas protegidas, propostos pela IUCN

\begin{tabular}{|c|c|}
\hline PRINCÍPIOS & CONSIDERAÇÕES \\
\hline \multirow{8}{*}{ Legitimidade e voz } & 1. Estabelecer e manter instituições de governança amplamente aceitas e apreciadas pela sociedade \\
\hline & $\begin{array}{l}\text { 2. Assegurar que todos recebam informações adequadas e suficientes, que possam ser representados, } \\
\text { aconselhar e/ou auxiliar na tomada de decisões }\end{array}$ \\
\hline & $\begin{array}{l}\text { 3. Promover o engajamento ativo dos atores sociais em apoio às áreas protegidas, mantendo a diversidade } \\
\text { e a equidade de gênero }\end{array}$ \\
\hline & $\begin{array}{l}\text { 4. Estender apoio especial aos grupos mais vulneráveis (e.g. indígenas, mulheres e jovens) e prevenir a } \\
\text { discriminação com base na etnia, gênero, classe social, ativos financeiros, etc. }\end{array}$ \\
\hline & $\begin{array}{l}\text { 5. Manter um diálogo ativo e buscar consenso em soluções que atendam, pelo menos em parte, as } \\
\text { preocupações e o interesse de todos }\end{array}$ \\
\hline & 6. Promover o respeito mútuo entre todos os detentores de direitos e partes interessadas \\
\hline & 7. Cumprir as regras acordadas \\
\hline & $\begin{array}{l}\text { 8. Atribuir, tanto quanto possível, autoridade de gestão e responsabilidade às instituições capazes de gerir } \\
\text { os recursos naturais locais (subsidiariedade) }\end{array}$ \\
\hline \multirow{5}{*}{ Direção } & $\begin{array}{l}\text { 9. Desenvolver e seguir uma visão estratégica (ampla, em uma perspectiva de longo prazo) consistente e } \\
\text { inspiradora para as áreas protegidas e seus objetivos de conservação, fundamentada em valores acordados } \\
\text { e considerando as complexidades ecológicas, históricas, sociais e culturais de cada local }\end{array}$ \\
\hline & $\begin{array}{l}\text { 10. Garantir que as práticas de governança e de gestão das áreas protegidas sejam consistentes com os } \\
\text { valores acordados, compatíveis e bem coordenadas com os planos e políticas de outros níveis e setores da } \\
\text { paisagem, respeitando as obrigações nacionais e internacionais }\end{array}$ \\
\hline & $\begin{array}{l}\text { 11. Fornecer orientações políticas claras para as principais questões de interesse para a área protegida (em } \\
\text { particular, para questões contenciosas) e assegurar que estas sejam consistentes com as dotações } \\
\text { orçamentais e as práticas de gestão }\end{array}$ \\
\hline & $\begin{array}{l}\text { 12. Avaliar e orientar o progresso da área protegida com base nos resultados de monitoramento, através } \\
\text { das abordagens da gestão adaptativa }\end{array}$ \\
\hline & $\begin{array}{l}\text { 13. Favorecer o surgimento de novas ideias, permitindo e promovendo cuidadosamente inovações na } \\
\text { governança e gestão para as áreas protegidas }\end{array}$ \\
\hline \multirow{4}{*}{ Desempenho } & $\begin{array}{l}\text { 14. Responder às necessidades de todos, fornecendo respostas oportunas e efetivas a consultas e demandas } \\
\text { sobre as práticas de governança e gestão }\end{array}$ \\
\hline & $\begin{array}{l}\text { 15. Assegurar que os profissionais e demais partes interessadas em áreas protegidas tenham as capacidades } \\
\text { necessárias para assumir as suas funções e responsabilidades de gestão e que essas capacidades sejam } \\
\text { utilizadas de forma adequada }\end{array}$ \\
\hline & 16. Tornar eficiente o uso dos recursos financeiros e promover a sustentabilidade financeira \\
\hline & $\begin{array}{l}\text { 17. Promover a sustentabilidade social e a resiliência (e.g. capacidade de gerenciar riscos e superar as } \\
\text { crises inevitáveis) }\end{array}$ \\
\hline \multirow{7}{*}{ Responsabilidade } & 18. Manter a integridade e o compromisso de todos os responsáveis pelas áreas protegidas \\
\hline & 19. Assegurar a transparência nos processos de decisão, garantir que todos tenham acesso à informação \\
\hline & $\begin{array}{l}\text { 20. Assegurar que os recursos financeiros e humanos alocados para gerenciar as áreas protegidas sejam } \\
\text { adequadamente direcionados de acordo com os objetivos e planos declarados }\end{array}$ \\
\hline & $\begin{array}{l}\text { 21. Avaliar o desempenho da área protegida, dos seus tomadores de decisão e dos seus funcionários e } \\
\text { relacionar a qualidade dos resultados com recompensas e sanções concretas e apropriadas }\end{array}$ \\
\hline & $\begin{array}{l}\text { 22. Estabelecer vias de comunicação (e.g. websites) onde os registros de desempenho e relatórios de áreas } \\
\text { protegidas são acessíveis }\end{array}$ \\
\hline & 23. Encorajar o engajamento da sociedade civil e da mídia \\
\hline & $\begin{array}{l}\text { 24. Assegurar que instituições públicas independentes tenham autoridade e capacidade para supervisionar } \\
\text { e questionar as ações dos órgãos governamentais e dos profissionais dad área protegida }\end{array}$ \\
\hline \multirow{2}{*}{ Equidade e direitos } & $\begin{array}{l}\text { 25. Esforçar-se para uma partilha equitativa dos custos e benefícios do estabelecimento e gestão de áreas } \\
\text { protegidas e da equidade na tomada de todas as decisões relevantes }\end{array}$ \\
\hline & $\begin{array}{l}\text { 26. Assegurar que os meios de subsistência de grupos de pessoas vulneráveis não sejam prejudicados pelas } \\
\text { áreas protegidas; }\end{array}$ \\
\hline
\end{tabular}




\begin{tabular}{|c|c|}
\hline \multirow{8}{*}{ Equidade e direitos } & $\begin{array}{l}\text { 27. Assegurar que a conservação seja empreendida com decência e dignidade, sem humilhar ou prejudicar } \\
\text { as pessoas }\end{array}$ \\
\hline & 28. Tratar adequadamente todos os profissionais das áreas protegidas \\
\hline & 29. Aplicar leis e regulamentos de maneira imparcial \\
\hline & $\begin{array}{l}\text { 30. Tomar medidas concretas para respeitar os direitos substantivos (legais ou costumeiros, coletivos ou } \\
\text { individuais) sobre a terra, a água e os recursos naturais relacionados às áreas protegidas, e para corrigir } \\
\text { violações anteriores de tais direitos }\end{array}$ \\
\hline & $\begin{array}{l}\text { 31. Tomar medidas concretas para respeitar os direitos processuais em matéria de áreas protegidas (e.g. } \\
\text { informação e consulta adequadas ao público e práticas justas de gestão de conflitos) }\end{array}$ \\
\hline & 32. Respeitar os direitos humanos, incluindo os direitos individuais e coletivos, e a igualdade de gênero \\
\hline & $\begin{array}{l}\text { 33. Garantir estritamente o livre, prévio e informado consentimento dos povos indígenas para qualquer } \\
\text { proposta de reassentamento relacionado com áreas protegidas }\end{array}$ \\
\hline & 34. Promover o engajamento ativo da sociedade na criação e no controle das áreas protegidas \\
\hline
\end{tabular}

Fonte: Elaborado pela autora (2016), a partir de Borrini-Feyerabend e Hill (2015).

A partir do quadro 15, é possível verificar cinco princípios principais (legitimidade e voz; direção; desempenho; responsabilidade; equidade e direitos) e diversas considerações para uma boa governança, as quais se mostraram aplicáveis e relevantes para os diversos tipos de áreas protegidas (BORRINI-FEYERABEND; HILL, 2015). Desse modo, os princípios e considerações apresentados no quadro são considerados fundamentais para uma boa governança em áreas protegidas urbanas, visto que a conservação da biodiversidade pode ser mais dificultosa e complexa nesses locais (SUNDSETH; RAEYMAEKERS, 2006; TRZYNA, 2015), bem como devido às áreas urbanas serem locais muito mais dinâmicos, abrigando uma intensidade de processos, desenvolvimentos e fluxos de pessoas (SUNDSETH; RAEYMAEKERS, 2006).

Em relação ao primeiro princípio (legitimidade e voz), as autoridades governamentais devem garantir e preservar os interesses coletivos e promover o engajamento e participação da sociedade em todos os níveis da tomada de decisão, através de uma gestão ativa e participativa de todas as partes interessadas envolvidas com as áreas protegidas urbanas (BORRINIFEYERABEND; HILL, 2015). Além disso, espera-se que a sociedade deva atuar no controle dos exercícios dos poderes concedidos às autoridades responsáveis por essas áreas, garantindo que os recursos naturais sejam conservados e mantidos para as próximas e atuais gerações (BORRINIFEYERABEND; HILL, 2015). Desse modo, a boa governança em áreas protegidas urbanas depende do apoio mútuo e engajamento entre governos, instituições diversas e da sociedade civil.

O segundo princípio (direção) exige das autoridades e responsáveis pelas áreas protegidas urbanas que sigam com os acordos (nacionais e internacionais) estabelecidos, definam as responsabilidades de cada um e forneçam orientações aos profissionais e à sociedade de maneira 
clara e objetiva, seguindo objetivos estratégicos consistentes e aplicáveis (BORRINIFEYERABEND; HILL, 2015).

Já o terceiro princípio (desempenho), destaca-se que as autoridades governamentais devem possuir habilidades para desempenhar as funções exigidas, identificar os riscos, incorporar novos conhecimentos e aprendizagens em um processo colaborativo, através de avaliações de efetividade de governança e gestão (BORRINI-FEYERABEND; HILL, 2015). Devem também promover o engajamento da população, para que esta seja aliada na defesa das áreas protegidas urbanas (BORRINI-FEYERABEND; HILL, 2015). Além disso, devem proporcionar aos profissionais das áreas protegidas urbanas treinamentos para que estes possam cumprir as suas funções, bem como devem garantir que os recursos financeiros sejam suficientes e bem distribuídos (BORRINIFEYERABEND; HILL, 2015).

As autoridades e demais responsáveis devem também adotar o princípio de responsabilidade. Dentre as considerações atribuídas, eles devem assegurar a transparência nos processos de decisão, garantindo com que que todos tenham acesso à informação (e.g. disponibilização de relatórios anuais, atas de reuniões de conselhos e comitês) (BORRINIFEYERABEND; HILL, 2015). Para tanto, as Instituições públicas e/ou privadas responsáveis devem estabelecer vias de comunicação onde os registros de desempenho e relatórios sejam acessíveis (BORRINI-FEYERABEND; HILL, 2015). Por último, os princípios de equidade e direitos devem garantir a justiça e cumprimento das normas e diretrizes que envolvam as áreas protegidas urbanas, bem como mediar os interesses e conflitos prevalecendo os interesses coletivos (BORRINI-FEYERABEND; HILL, 2015).

Em suma, as autoridades responsáveis pela governança em áreas protegidas urbanas devem garantir normas e diretrizes fortes e aplicáveis, bem como devem possuir capacidade para implementá-las (SANDWITH, 2015). Logo, Trevor Sandwith (2015) ${ }^{110}$ aconselha que os níveis federal, estadual e municipal devem estar conectados e devem reconhecer que as áreas protegidas urbanas são vitais para seus territórios, e desse modo, garantir um suporte para as gestões em todas as esferas administrativas.

Nesse sentido, Sandwith (2015) adverte que uma das possíveis soluções para se conter as pressões e ameaças típicas de áreas urbanas é através da inclusão de todas as áreas verdes naturais

\footnotetext{
${ }^{110}$ Informação fornecida por Trevor Sandwith, diretor do Programa Global de Áreas Protegidas da IUCN, durante uma visita técnica da autora à sede da organização em Gland (Suíça), em 2015.
} 
presentes nas cidades (incluindo as áreas protegidas já estabelecidas) em um grande plano de conservação da biodiversidade. A ideia é integrar o conceito de conservação da biodiversidade dentro dos processos de planejamento dos territórios, através de legislações e diretrizes específicas (SANDWITH, 2015).

De maneira geral, as sociedades devem compreender que todos os setores econômicos e sociais são totalmente dependentes da biodiversidade existente, através do fornecimento de serviços ecossistêmicos, os quais são vitais para a sobrevivência das populações (SANDWITH, 2015). Logo, as autoridades devem adotar leis referentes ao planejamento do uso do solo e implementar estratégias nacionais referentes à proteção da biodiversidade em planos de ação que irão permitir o reconhecimento das redes de áreas protegidas e uma melhor coordenação entre as diferentes unidades administrativas (SANDWITH, 2015). Nesse contexto, cada gestor de uma área protegida urbana poderia trabalhar conjuntamente com outros atores do território, em um amplo plano de ação ${ }^{111}$ (SANDWITH, 2015).

\subsection{Gestão de Áreas Protegidas Urbanas}

Segundo Faria (2004, p.39) a gestão de UCs pode ser definida como:

A equilibrada coordenação dos componentes técnicos e operacionais (recursos humanos, materiais, financeiros) e os diversos atores sociais que incidem sobre o desenvolvimento da área, de maneira tal a obter-se a eficácia requerida para se lograr os objetivos para os quais a unidade foi criada e a manutenção da produtividade dos ecossistemas abrangidos.

Nesse sentido, as áreas protegidas e, em especial, as áreas protegidas urbanas, necessitam de uma gestão ativa e adequada para responder aos inúmeros desafios e questões (e.g. ambientais, sociais, econômicas e políticas) relacionadas ao seu entorno (WORBOY; TRZYNA, 2015). Desse modo, devido às inúmeras tarefas a cargo das gestões e para que essas áreas cumpram com os seus objetivos e consequentemente beneficiem às populações urbanas, é fundamental que os responsáveis por essas áreas ajam de maneira planejada (WORBOY; TRZYNA, 2015). Para tanto, é necessário compreender o processo de gestão de uma área protegida urbana.

O plano de manejo é o principal instrumento de uma área protegida e consiste no documento técnico que contém as diretrizes gerais que irão nortear a sua gestão (FERNANDES; HANGAE; MOTA, 2011). Desse modo, entende-se que este plano é fundamental para todas as áreas

${ }^{111}$ Um exemplo dessa estratégia é observado na África do Sul, através da criação do Biodiversity Sector Plan (VROMANS et al., 2010). 
protegidas, e em especial para as urbanas, visto os inúmeros desafios e dificuldades que possuem se comparadas com as mais remotas.

De maneira geral, são necessárias algumas etapas para a elaboração do plano de manejo, tais como: I) organização e planejamento; II) sistematização e análise das informações disponíveis; III) levantamento de campo; IV) oficina de pesquisadores; V) oficina de planejamento participativo; VI) elaboração do diagnóstico da área protegida; VII) estruturação do planejamento; VIII) avaliação do plano de manejo; IX) aprovação e divulgação do plano de manejo e X) implementação, monitoria e avaliação do plano de manejo (FERNANDES; HANGAE; MOTA, 2011). A figura 34 ilustra o processo de elaboração do plano de manejo.

Figura 34. Esquema ilustrando o processo de elaboração de um plano de manejo.

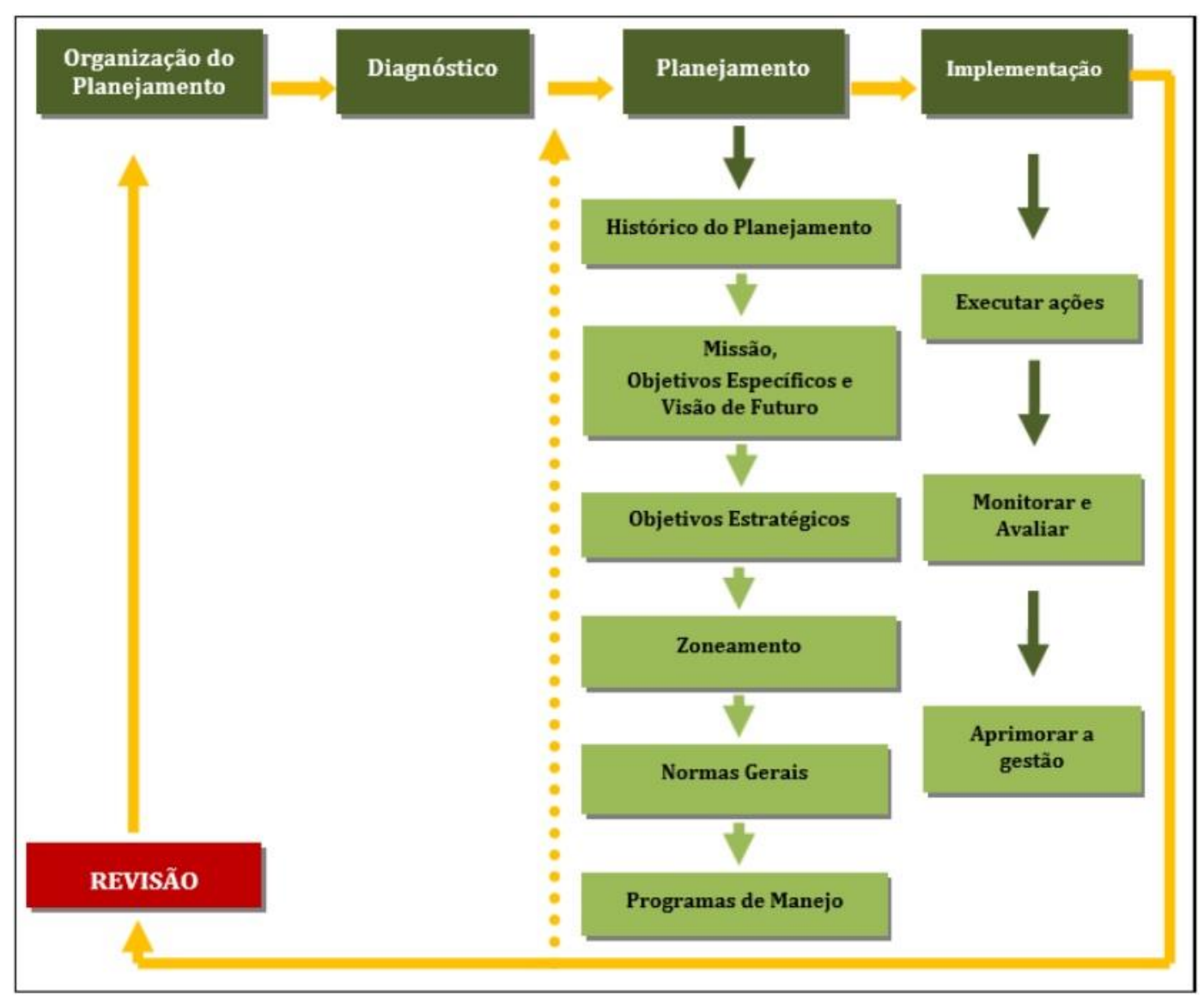

Fonte: Fernandes, Hangae e Mota (2011).

Desse modo, o ciclo de gestão de uma área protegida pode ser caracterizado como um ciclo dinâmico, composto pelas etapas de planejamento, implementação, monitoramento e avaliação do planejamento (FERNANDES; HANGAE; MOTA, 2011; WORBOY; TRZYNA, 2015). 


\section{Planejamento}

A primeira etapa do ciclo de gestão é dividida em três níveis (WORBOY; TRZYNA, 2015), ilustrados na figura 35 .

Figura 35. Esquema ilustrativo sobre os diferentes níveis de planejamento: estratégico, tático e operacional.

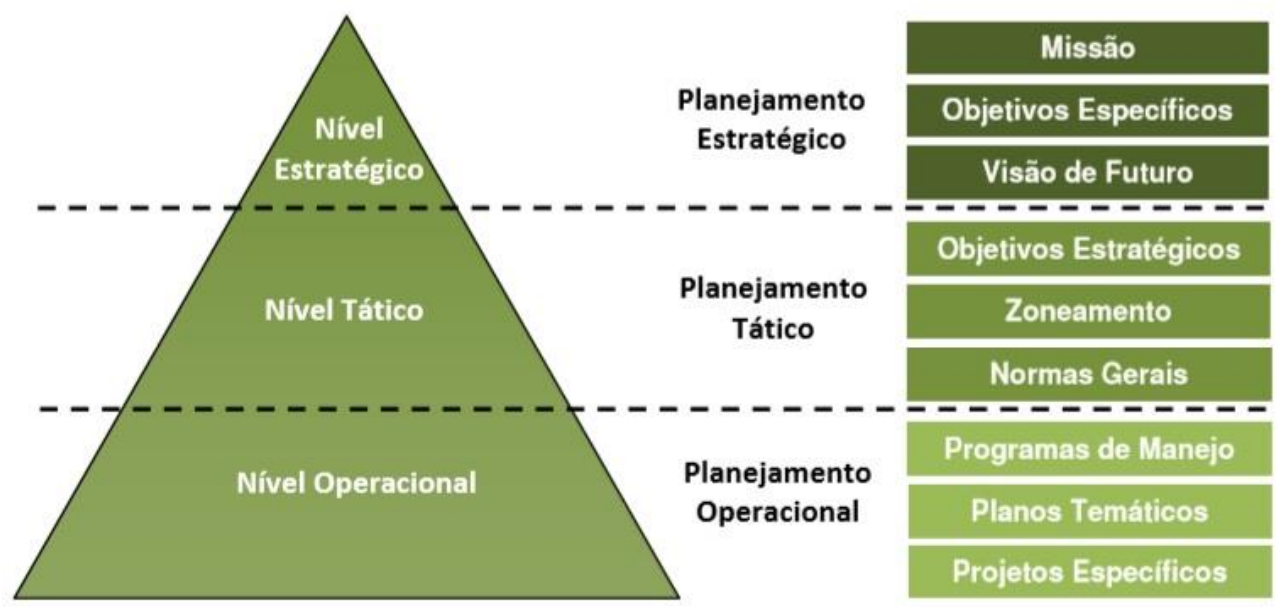

Fonte: Fernandes, Hangae e Mota (2011).

A partir de diagnósticos produzidos nas áreas protegidas urbanas, os quais fornecerão informações sobre o estado atual da área protegida, segue-se para a etapa de planejamento estratégico. Esta etapa fornece a direção a ser seguida, onde se define a missão, objetivos específicos e a visão de futuro da área protegida urbana (FERNANDES; HANGAE; MOTA, 2011; WORBOY; TRZYNA, 2015). Esta etapa é fundamental para se saber qual o cenário almejado para a área a longo prazo e quais estratégias serão definidas para se chegar até ele.

Fernandes, Hangae e Mota (2011) advertem que a visão de futuro deve ser elaborada de maneira conjunta com os diversos atores envolvidos (e.g. comunidade do entorno, visitantes, organizações públicas e privadas, pesquisadores, etc.), reconhecendo os interesses e desejos de todos, através da realização de oficinas participativas no processo de elaboração do plano de manejo.

Para o segundo nível de planejamento (tático), são definidos os objetivos estratégicos da área protegida urbana, a partir de metas e indicadores, consolidando-se o seu zoneamento e as diretrizes gerais que deverão ser seguidas com a sua implementação (FERNANDES; HANGAE; MOTA, 2011). Esta etapa também auxilia na ordenação, indicando as prioridades na implementação das metas (WORBOY; TRZYNA, 2015). 
Para a definição dos objetivos estratégicos, utiliza-se como subsídio matrizes de análises estratégicas (e.g. através dos resultados da Análise de Forças) ${ }^{112}$, trabalhadas nas oficinas participativas de planejamento (FERNANDES; HANGAE; MOTA, 2011). As matrizes de análises estratégicas permitem definir as prioridades da área protegida, através da identificação das principais causas das ameaças e das oportunidades (FERNANDES; HANGAE; MOTA, 2011).

A terceira e última etapa de planejamento (operacional) consiste na definição dos programas de manejo, planos e projetos, os quais reúnem as ações de conservação necessárias para que a UC alcance a sua visão, cumpra sua missão e seus objetivos específicos (FERNANDES; HANGAE; MOTA, 2011).

Nesse sentido, para esta etapa a IUCN propõe trinta orientações e melhores práticas, divididas em diferentes categorias, a serem implementadas em áreas protegidas urbanas, ilustradas no quadro 16. Elas foram criteriosamente selecionadas conforme as análises realizadas em 15 áreas protegidas urbanas de diferentes regiões do mundo, situações socioeconômicas, ambientes naturais, tamanhos e modelos de gestão (TRZYNA, 2014).

${ }^{112}$ Conhecida como FOFA - Análise de Fortalezas, Oportunidades, Fraquezas e Ameaças. Em inglês: SWOT analysis: strengths, weaknesses, opportunities and threats. 
Quadro 16. Categorias, orientações e melhores práticas e exemplos.

\begin{tabular}{|c|c|c|}
\hline CATEGORIAS & $\begin{array}{l}\text { ORIENTAÇÕES E MELHORES } \\
\text { PRÁTICAS }\end{array}$ & EXEMPLOS \\
\hline \multirow{11}{*}{$\begin{array}{l}\text { ÁREAS PROTEGIDAS } \\
\text { URBANAS E PESSOAS }\end{array}$} & $\begin{array}{l}\text { 1. Fornecer acesso para todos; alcançar os } \\
\text { diversos grupos étnicos e os mais } \\
\text { desfavorecidos }\end{array}$ & $\begin{array}{l}\text { Implementar sinalização necessária e considerar o uso de diferentes idiomas quando necessário; } \\
\text { fornecer informações facilmente acessíveis sobre serviços de transporte disponíveis; incentivar } \\
\text { os serviços públicos de transporte; }\end{array}$ \\
\hline & 2. Promover um senso local de propriedade & $\begin{array}{l}\text { Promover a valorização dos bens culturais, históricos e naturais da área protegida; } \\
\text { disponibilizar instalações para eventos de agências governamentais, ONGs, comunidades locais } \\
\text { e empresas; }\end{array}$ \\
\hline & 3. Envolver voluntários e grupos de apoio & $\begin{array}{l}\text { Promover o engajamento de pessoas voluntárias de suas regiões e aproveitar o potencial de } \\
\text { grupos de apoio (e.g. ONGs, parceiros, associações cooperativas); }\end{array}$ \\
\hline & $\begin{array}{l}\text { 4. Comunicar com cuidado e usar uma } \\
\text { variedade de tecnologias de comunicação }\end{array}$ & $\begin{array}{l}\text { Sensibilizar a população sobre a importância da área protegida urbana; utilizar diferentes } \\
\text { estratégias de comunicação e usar uma variedade de tecnologias de comunicação (e.g. } \\
\text { publicações impressas, websites, blogs, aplicativos e mídias sociais); }\end{array}$ \\
\hline & $\begin{array}{l}\text { 5. Demonstrar, facilitar e promover o bom } \\
\text { comportamento ambiental }\end{array}$ & $\begin{array}{l}\text { Informar e envolver os visitantes nas discussões sobre as causas e conseqüências das principais } \\
\text { pressões e ameaças (e.g. demonstrar e facilitar a redução, reutilização e reciclagem de } \\
\text { materiais); }\end{array}$ \\
\hline & $\begin{array}{l}\text { 6. Demonstrar, facilitar e promover } \\
\text { experiências com o meio ambiente }\end{array}$ & $\begin{array}{l}\text { Ajudar as pessoas a entender que passar tempo em áreas naturais melhora a saúde física e } \\
\text { mental; }\end{array}$ \\
\hline & 7. Evitar resíduos & $\begin{array}{l}\text { Utilizar os resultados de pesquisas locais sobre resíduos; limpar as áreas com freqüência; } \\
\text { fornecer lixeiras em locais estratégicos; }\end{array}$ \\
\hline & 8. Prevenir crimes & Articular com agências de policiamento locais; combater o vandalismo; \\
\hline & $\begin{array}{l}\text { 9. Reduzir a interação e conflitos entre humano } \\
\text { e animais selvagens; conscientizar sobre as } \\
\text { doenças infecciosas emergentes. }\end{array}$ & $\begin{array}{l}\text { Incentivar atitudes respeitosas em relação à vida selvagem; sensibilizar a população sobre a } \\
\text { transmissão de doenças entre outros animais e seres humanos; }\end{array}$ \\
\hline & 10. Controlar a caça ilegal & Aplicar leis; participar de esforços inter-agências de combate à caça; \\
\hline & $\begin{array}{l}\text { 11. Controlar espécies invasoras de animais e } \\
\text { plantas }\end{array}$ & $\begin{array}{l}\text { Detectar previamente novas invasões; participar em parcerias locais e nacionais para } \\
\text { prevenção, detecção precoce, erradicação e controle. }\end{array}$ \\
\hline \multirow{4}{*}{$\begin{array}{l}\text { ÁREAS PROTEGIDAS } \\
\text { URBANAS E LUGARES }\end{array}$} & $\begin{array}{l}\text { 12. Promover conexões com outras áreas } \\
\text { naturais }\end{array}$ & $\begin{array}{l}\text { Cooperar com agências públicas e ONGs para conter ou orientar a expansão urbana; criar e } \\
\text { manter zonas-tampão e corredores que se conectem a outras áreas naturais; }\end{array}$ \\
\hline & $\begin{array}{l}\text { 13. Incorporar elementos naturais no ambiente } \\
\text { urbano }\end{array}$ & $\begin{array}{l}\text { Participar de coligações regionais de conservação da natureza; projetos para desenvolver } \\
\text { estratégias locais de conservação da biodiversidade; esforços para proteger, restaurar e } \\
\text { introduzir elementos naturais no ambiente urbano; }\end{array}$ \\
\hline & 14. Controlar invasões & $\begin{array}{l}\text { Fiscalizar; fazer cumprir a lei; articular com autoridades locais e obter a cooperação da } \\
\text { população local; }\end{array}$ \\
\hline & 15. Monitorar e manejar os recursos hídricos & $\begin{array}{l}\text { Averiguar as tendências e projeções de quantidade e qualidade da água; trabalhar em estreita } \\
\text { colaboração com aqueles que partilham a responsabilidade pela gestão da água; }\end{array}$ \\
\hline
\end{tabular}




\begin{tabular}{|c|c|c|}
\hline CATEGORIAS & ORIENTAÇÕES E MELHORES PRÁTICAS & EXEMPLOS \\
\hline \multirow{2}{*}{$\begin{array}{l}\text { ÁREAS PROTEGIDAS } \\
\text { URBANAS E LUGARES }\end{array}$} & 16. Manejar incêndios & $\begin{array}{l}\text { Controlar os incêndios que ameaçam as espécies naturais e os ecossistemas; articular } \\
\text { com os responsáveis pela prevenção e controle de incêndios nas áreas urbanas } \\
\text { vizinhas; }\end{array}$ \\
\hline & $\begin{array}{l}\text { 17. Reduzir os impactos de ruídos e luzes noturnas } \\
\text { artificiais; acompanhar pesquisas sobre radiação } \\
\text { electromagnética }\end{array}$ & $\begin{array}{l}\text { Reduzir ruídos e promover a valorização dos sons naturais; reduzir luzes noturnas } \\
\text { artificiais; promover a apreciação do céu noturno; promover pesquisas com campos } \\
\text { eletromagnéticos; }\end{array}$ \\
\hline \multirow{5}{*}{$\begin{array}{l}\text { ÁREAS PROTEGIDAS } \\
\text { URBANAS } \\
\text { E INSTITUIÇÕES }\end{array}$} & $\begin{array}{l}\text { 18. Cooperar com as agências que têm compartilhado } \\
\text { jurisdições ou jurisdições adjacentes }\end{array}$ & $\begin{array}{l}\text { Formar e manter relações de cooperação com agências; fazer acordos formais sobre a } \\
\text { gestão de problemas específicos; }\end{array}$ \\
\hline & $\begin{array}{l}\text { 19. Cooperar com instituições que têm missões } \\
\text { complementares }\end{array}$ & $\begin{array}{l}\text { Cooperar com outros atores urbanos para oferecer experiências com ambientes } \\
\text { naturais e educação ambiental; encorajar e auxiliar museus de história natural, jardins } \\
\text { zoológicos, aquários e jardins botânicos para fornecer informações e exposições sobre } \\
\text { a conservação e desafios em suas regiões; }\end{array}$ \\
\hline & 20. Formar uma ampla rede de defensores e aliados & $\begin{array}{l}\text { Envolver-se com a comunidade do entorno, apoiá-la sempre que possível e buscar } \\
\text { aliados de novos setores; }\end{array}$ \\
\hline & $\begin{array}{l}\text { 21. Cooperar com universidades na formação de gestores } \\
\text { para as áreas protegidas urbanas; facilitar o uso dessas áreas } \\
\text { para a pesquisa acadêmica e aprendizagem avançada }\end{array}$ & $\begin{array}{l}\text { Ajudar a divulgar e arquivar os resultados de pesquisas; incentivar as universidades a } \\
\text { desenvolver pesquisas e treinamentos em áreas protegidas urbanas; }\end{array}$ \\
\hline & 22. Aprender com a experiência dos outros & $\begin{array}{l}\text { Aproveitar pessoas com habilidades empresariais e especialistas em negociações; } \\
\text { aprender diferentes maneiras de resolver conflitos; }\end{array}$ \\
\hline \multirow{8}{*}{$\begin{array}{c}\text { PROMOVENDO, } \\
\text { CRIANDO } \\
\text { E MELHORANDO ÁREAS } \\
\text { PROTEGIDAS URBANAS }\end{array}$} & 23. Promover e defender áreas protegidas urbanas & $\begin{array}{l}\text { Sensibilizar a população sobre a sua importância para a conservação local, nacional e } \\
\text { global; }\end{array}$ \\
\hline & $\begin{array}{l}\text { 24. Trabalhar para tornar as áreas protegidas urbanas } \\
\text { prioridades nacionais e globais de conservação }\end{array}$ & Incluí-las em estratégias de conservação e planos de sistemas de áreas protegidas; \\
\hline & 25. Criar e expandir as áreas protegidas urbanas & $\begin{array}{l}\text { Examinar possíveis locais e trabalhar com autoridades de planejamento do uso do solo } \\
\text { para incluir áreas protegidas como parte da urbanização projetada; }\end{array}$ \\
\hline & $\begin{array}{l}\text { 26. Promover regras e culturas organizacionais que } \\
\text { respeitem as diferenças entre áreas protegidas urbanas e } \\
\text { aquelas mais remotas. }\end{array}$ & $\begin{array}{l}\text { Trabalhar para mudar legislações, regulamentos e práticas que reconheçam essas } \\
\text { diferenças; Sensibilizar sobre as principais diferenças e características desses locais; }\end{array}$ \\
\hline & $\begin{array}{l}\text { 27. Reconhecer que as habilidades políticas são } \\
\text { fundamentais para obter sucesso e fortalecê-las }\end{array}$ & $\begin{array}{l}\text { Reconhecer que os profissionais de áreas protegidas urbanas requerem habilidades } \\
\text { políticas fortes; reforçar as competências políticas através de cursos e orientações; }\end{array}$ \\
\hline & 28. Buscar financiamento de uma ampla gama de fontes & $\begin{array}{l}\text { Aproveitar as diferentes fontes de financiamento disponíveis para apoiar áreas } \\
\text { protegidas; }\end{array}$ \\
\hline & $\begin{array}{l}\text { 29. Fazer parcerias com organizações internacionais e fazer } \\
\text { intercâmbios }\end{array}$ & $\begin{array}{l}\text { Estar ciente das organizações internacionais e do que elas podem oferecer; realizar } \\
\text { intercâmbios com gestores de áreas urbanas protegidas de outros países; }\end{array}$ \\
\hline & $\begin{array}{l}\text { 30. Melhorar as áreas protegidas urbanas por meio de } \\
\text { pesquisa e avaliação }\end{array}$ & $\begin{array}{l}\text { Compreender o valor das pesquisas e avaliações de efetividade; desenvolver agendas } \\
\text { de pesquisa em áreas protegidas urbanas. }\end{array}$ \\
\hline
\end{tabular}

Fonte: Elaborada pela autora (2016), a partir de Trzyna (2014). 
Conforme ilustrado no quadro 16, a IUCN fornece orientações e melhores práticas para serem implementadas em áreas protegidas urbanas, divididas em quatro categorias. A primeira categoria (áreas protegidas urbanas e pessoas) tem como objetivo dar indicações sobre como lidar com os problemas resultantes da relação de indivíduos com esses locais, focando nos principais problemas averiguados nos casos de estudos analisados pela IUCN (TRZYNA, 2014). Similarmente, as demais categorias são referentes aos lugares e instituições que as áreas protegidas urbanas se relacionam, bem como a última categoria visa especificamente promover, criar e melhorar esses locais (TRZYNA, 2014).

Logo, para que seja possível executar os três níveis de planejamento (estratégico, tático e operacional), alguns autores (TRZYNA, 2014; WORBOYS; TRZYNA, 2015) advertem que a etapa de planejamento deve incorporar concepções das abordagens racionais, adaptativas e participativas.

De maneira geral, a abordagem racional consiste na definição de metas, objetivos e adoção de ações baseadas na razão e na lógica, resultando em decisões que podem ser claramente explicadas e justificadas (e.g. realização de projeções a partir dos resultados; avaliação dos resultados com base em critérios objetivos; articulação de metas e objetivos) (WORBOYS; TRZYNA, 2015).

Já uma abordagem adaptativa busca superar os desafios e os cenários de incerteza, analisando de forma sistemática os problemas e integrando ao processo de gestão informações e novos conhecimentos obtidos (WORBOYS; TRZYNA, 2015). Essa abordagem preza por revisões constantes das ações que são adotadas, as quais devem sempre ser adaptadas frente aos novos desafios, visando uma melhora do sistema de gestão (WORBOYS; TRZYNA, 2015). Logo, a implementação de programas que visem o monitoramento e a documentação sistemáticos irão auxiliar as gestões durante a avaliação do ciclo de gestão, para que assim adotem ações de conservação que sejam eficientes no cumprimento de seus objetivos. Worboys e Trzyna (2015) prezam que os resultados e documentos obtidos devem ser compartilhados com especialistas e com a sociedade civil, auxiliando no processo de tomada de decisão. Além disso, os autores advertem que o planejamento adaptativo parece ser a melhor maneira para lidar com projetos de conservação, visto que em muitos casos não se tem conhecimento suficiente para mitigar um problema e, portanto, as gestões devem planejar suas ações conforme o conhecimento disponível e com o passar do tempo, sejam avaliadas e adaptadas segundo novas informações forem surgindo.

O processo de planejamento das áreas protegidas urbanas devem conter concepções da abordagem participativa (TRZYNA, 2014; WORBOYS; TRZYNA, 2015). Nesta abordagem, 
deve haver a participação da sociedade civil e demais organizações externas envolvidas nos processos de planejamento da área protegida urbana (e.g. lideranças políticas, organizações locais, etc.). Logo, entende-se que na ausência desses atores, torna-se mais difícil a implementação de ações de conservação e a obtenção dos resultados almejados.

Não obstante, Trzyna (2014) alega como essencial para a resolução de conflitos em áreas protegidas urbanas a gestão reconhecer os interesses dos diversos indivíduos e os objetivos conflitantes, bem como fomentar a participação das comunidades locais. Nesse sentido, diante dos divergentes interesses de cada grupo, já se sabe que o engajamento da sociedade civil desde o início do processo de planejamento de uma área protegida traz benefícios para todas as partes envolvidas (WORBOYS; TRZYNA, 2015). Ademais, os diversos pontos de vista aumentam a qualidade das decisões, facilitando obtenção de resultados mais efetivos (WORBOYS; TRZYNA, 2015). Assim, constrói-se uma relação mais forte e melhorada entre a área protegida e a comunidade, promovendo parcerias e alianças intersetoriais que podem aumentar as chances dessas áreas alcançarem os seus objetivos (WORBOYS; TRZYNA, 2015).

Por fim, a figura 36 ilustra como deve ser o processo de planejamento em uma área protegida urbana (a partir da mistura das abordagens racional, adaptativa e participativa)

Figura 36. Esquema ilustrativo sobre o processo de planejamento (racional, adaptativo e participativo) em áreas protegidas urbanas.

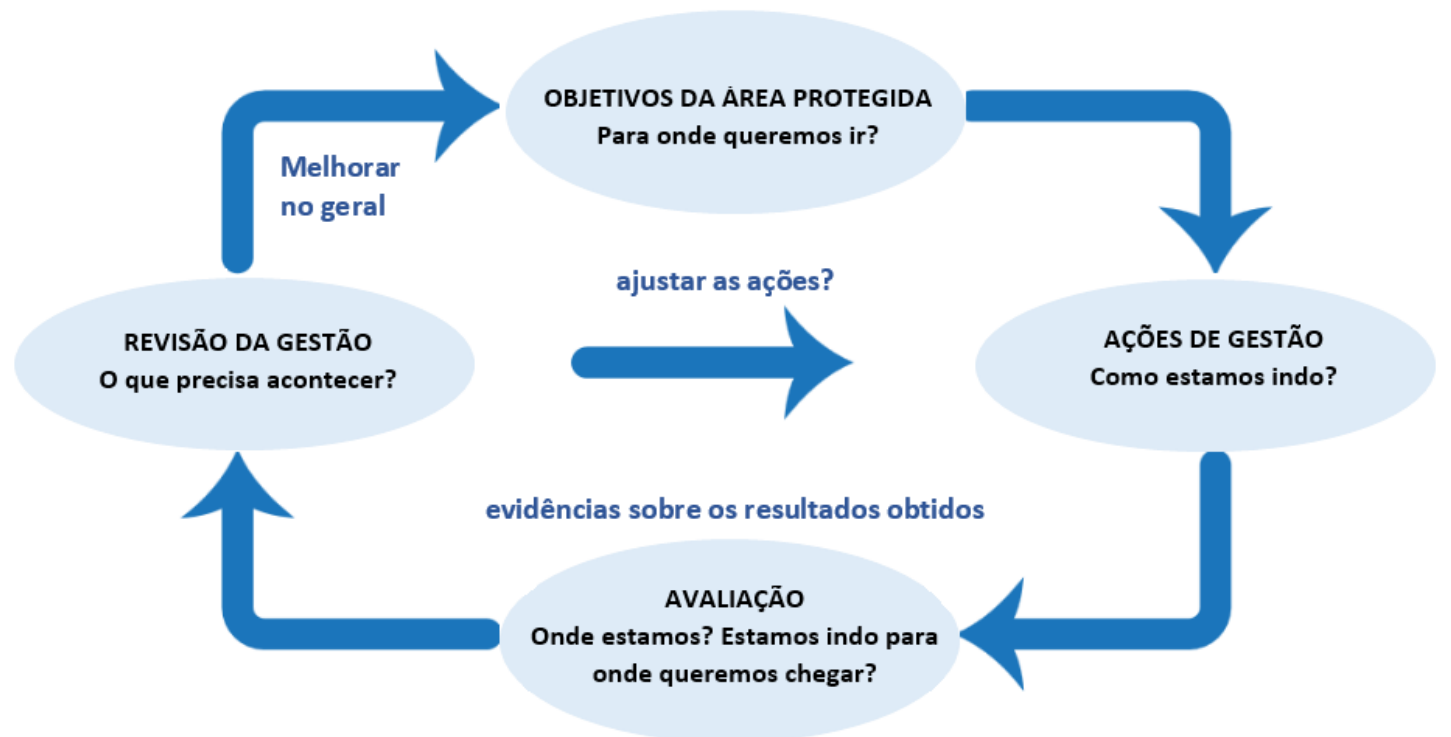

Fonte: Adaptado de Worboys e Trzyna (2015).

Implementação, monitoramento e avaliação

Após a etapa de planejamento da área protegida, inicia-se a implementação do plano de manejo. Todas as diretrizes e ações propostas neste plano devem ser monitoradas e avaliadas 
através dos indicadores e metas estabelecidos durante o processo de planejamento, a fim de viabilizar o manejo adaptativo (FERNANDES; HANGAE; MOTA, 2011).

Nesse sentido, Fernandes, Hangae e Mota (2011) aconselham que os planos de manejo devem ser executados em um prazo de 5 anos. Contudo, não significa que estes devam ser suspensos e refeitos após esse período. Significa que, após a gestão ter cumprido as etapas de planejamento, implementação, monitoramento e avaliação das medidas propostas, estas devem ser reavaliadas e reformuladas visto novas informações e circunstâncias que as inviabilizem, bem como caso os objetivos e metas tenham sido alcançados (FERNANDES; HANGAE; MOTA, 2011).

Observa-se também que a organização compõe uma das funções necessárias ao ciclo de gestão de uma área protegida (WORBOYS; TRZYNA, 2015). Nesse sentido, é necessário que os profissionais envolvidos na gestão de uma área protegida urbana saibam lidar com os problemas e desafios desses locais e executar as ações de conservação planejadas durante as operações rotineiras (WORBOYS; TRZYNA, 2015). Para tanto, devem coordenar de maneira adequada a obtenção de conhecimento, os recursos humanos e financeiros, os equipamentos, infraestruturas e serviços em geral (WORBOYS; TRZYNA, 2015).

Logo, exige-se pró-atividade e liderança dos profissionais envolvidos na gestão das áreas protegidas urbanas, os quais devem estar conscientes das suas responsabilidades perante aos inúmeros desafios impostos, evitando-se assim cenários de inadimplências (WORBOY; TRZYNA, 2015). No entanto, leva tempo e recursos para se atingir o status desejado de uma gestão adequada e ativa, para que os problemas e desafios sejam resolvidos, bem como para o desenvolvimento de diferentes habilidades necessárias aos profissionais envolvidos (WORBOY; TRZYNA, 2015). Além disso, a característica marcante dessas áreas é que estas se envolvem com diversos stakeholders e, frequentemente, exige-se mudanças de percepção destes indivíduos (WORBOY; TRZYNA, 2015).

Segundo Trzyna (2014), cada tipo de profissional possui tarefas específicas para serem implementadas ao longo do ciclo de gestão. Contudo, é fundamental existir oportunidades de capacitação e desenvolvimento apropriadas às necessidades de todos os funcionários envolvidos e que estes possuam conhecimento sobre as questões de conservação que envolvem às áreas protegidas urbanas. Verifica-se também que os profissionais envolvidos devem fomentar estudos científicos, os quais servirão de base para o planejamento de ações no ciclo de gestão, bem como tomar providências para garantir a qualidade dos pareceres científicos dos estudos realizados em suas áreas protegidas urbanas (TRZYNA, 2014). 
Em suma, o processo de implementação deve ser transparente e com propósitos bem definidos em relação à visão e missão da área protegida urbana (WORBOYS; TRZYNA, 2015). Desse modo, é necessário que as gestões responsáveis ajustem as suas prioridades, reorientem os investimentos e adaptem-se às novas circunstâncias sociais, políticas e ambientais que venham a surgir, para que às ações de conservação sejam bem-sucedidas (WORBOYS; TRZYNA, 2015).

\section{Considerações sobre os casos de estudos nacionais e internacionais}

O quadro 17 ilustra as principais diferenças observadas nos casos de estudos nacionais e internacionais e embasa a discussão deste tópico.

Quadro 17. Principais diferenças observadas nos casos de estudos nacionais e internacionais.

\begin{tabular}{|c|c|c|}
\hline CARACTERÍSTICAS & CASOS NACIONAIS & CASOS INTERNACIONAIS \\
\hline $\begin{array}{l}\text { Modelo de gestão e } \\
\text { governança }\end{array}$ & $\begin{array}{l}\text { Órgãos governamentais detêm a } \\
\text { autoridade e responsabilidade geral } \\
\text { pela gestão. }\end{array}$ & $\begin{array}{l}\text { Órgãos governamentais e não } \\
\text { governamentais (e.g. ONGs e entidades } \\
\text { privadas) detêm a autoridade e } \\
\text { responsabilidade geral pela gestão. }\end{array}$ \\
\hline \multirow{4}{*}{ Recursos financeiros } & $\begin{array}{l}\text { Os recursos financeiros são oriundos } \\
\text { apenas dos órgãos governamentais e } \\
\text { recursos de compensações } \\
\text { ambientais. }\end{array}$ & $\begin{array}{l}\text { Os recursos financeiros são oriundos dos } \\
\text { órgãos governamentais competentes, } \\
\text { recursos de compensações ambientais, } \\
\text { instituições do setor público e privado. }\end{array}$ \\
\hline & $\begin{array}{l}\text { Não há diversificação das fontes de } \\
\text { recursos. }\end{array}$ & $\begin{array}{l}\text { Equipes de gestão vêm buscando novas } \\
\text { fontes de recursos e maior suporte para a } \\
\text { conservação da área, tanto nos setores } \\
\text { públicos como privados. }\end{array}$ \\
\hline & \multicolumn{2}{|c|}{ Não há previsão financeira estável para os próximos cinco anos. } \\
\hline & $\begin{array}{l}\text { Não há possibilidades de concessões } \\
\text { atualmente. }\end{array}$ & Há possibilidade de concessões. \\
\hline Recursos humanos & $\begin{array}{l}\text { Foram considerados insuficientes } \\
\text { pelas equipes de gestão (com exceção } \\
\text { da EERP). }\end{array}$ & $\begin{array}{l}\text { Foram considerados insuficientes pelas } \\
\text { equipes de gestão (com exceção do } \\
\text { PNZK). }\end{array}$ \\
\hline \multirow[t]{2}{*}{$\begin{array}{l}\text { Participação da } \\
\text { sociedade civil }\end{array}$} & $\begin{array}{l}\text { Através de atividades de educação } \\
\text { ambiental e reuniões dos Conselhos } \\
\text { Consultivos (as quais ocorrem para o } \\
\text { atendimento das demandas das } \\
\text { câmaras técnicas). }\end{array}$ & $\begin{array}{l}\text { Através de atividades de educação } \\
\text { ambiental, projetos de integração e } \\
\text { reuniões dos Conselhos Consultivos (com } \\
\text { a supervisão conjunta dos membros sobre } \\
\text { as atividades desenvolvidas). }\end{array}$ \\
\hline & $\begin{array}{l}\text { Baixa participação em grupos de } \\
\text { apoio e programas de voluntariado. }\end{array}$ & $\begin{array}{l}\text { Alta participação e engajamento da } \\
\text { população em grupos de apoio e } \\
\text { programas de voluntariado. }\end{array}$ \\
\hline
\end{tabular}




\begin{tabular}{|c|c|c|}
\hline $\begin{array}{l}\text { Estratégias de } \\
\text { comunicação e } \\
\text { divulgação das } \\
\text { informações }\end{array}$ & $\begin{array}{l}\text { Poucas estratégias de comunicação e } \\
\text { divulgação das informações. } \\
\text { Divulgação de informações básicas } \\
\text { sobre às UCs ocorre através de } \\
\text { websites dos órgãos gestores, CNUC } \\
\text { (muitas informações desatualizadas) e } \\
\text { mídias locais (jornal, rádio e TV). De } \\
\text { maneira geral, não há uso de canais } \\
\text { de informação interativos. } \\
\end{array}$ & $\begin{array}{l}\text { Diferentes estratégias de comunicação e } \\
\text { divulgação das informações. Divulgação } \\
\text { de informações específicas sobre às áreas } \\
\text { protegidas ocorre através de websites } \\
\text { oficiais e interativos, revistas eletrônicas } \\
\text { bianuais, aplicativos e boletins eletrônicos } \\
\text { (periodicamente atualizadas e produzidas } \\
\text { em diferentes línguas). }\end{array}$ \\
\hline \multirow{2}{*}{ Pressões e ameaças } & \multicolumn{2}{|c|}{$\begin{array}{l}\text { Desenvolvimento urbano do entorno; estradas e rodovias; mudanças climáticas; } \\
\text { poluição atmosférica, hídrica, sonora e visual; espécies exóticas invasoras; } \\
\text { disposição de resíduos; extração de recursos não madeireiros; conflitos entre } \\
\text { humanos e animais selvagens; turismo e recreação; atividades industriais e crimes }\end{array}$} \\
\hline & $\begin{array}{l}\text { Incêndios florestais, ocupações } \\
\text { ilegais, atividades religiosas, disputas } \\
\text { sobre o uso d'água, linhas de } \\
\text { transmissão de energia e mineração. }\end{array}$ & $\begin{array}{l}\text { Atividades de pesca e transmissão de } \\
\text { doenças entre animais silvestres }\end{array}$ \\
\hline Planos de Manejo & $\begin{array}{l}\text { Planos de manejo com uma visão de } \\
\text { planejamento de } 5 \text { anos. }\end{array}$ & $\begin{array}{l}\text { Planos de manejo mais estratégicos, com } \\
\text { uma visão de planejamento entre } 10 \text { a } 20 \\
\text { anos. }\end{array}$ \\
\hline Amparo legal & $\begin{array}{l}\text { Lei 9.985/2000 (SNUC) e Lei } \\
n^{\circ} 10.257 / 2001 \text { (Estatuto da Cidade) }\end{array}$ & $\begin{array}{l}\text { Diretivas de Habitats e Aves da União } \\
\text { Europeia. }\end{array}$ \\
\hline
\end{tabular}

Fonte: Elaborado pela autora (2016).

Os casos de estudos nacionais apresentam modelos de governança e gestão centralizada no governo. O modelo de governança estatal, conforme mencionado no capítulo I, ocorre através de órgãos públicos, autarquias e fundações, com recursos, bens e agentes do próprio Estado (INSTITUTO SEMEIA, 2015). De maneira geral, observa-se que este modelo é menos flexível quando comparado aos demais, possuindo limitações gerenciais e orçamentárias, com grande ingerência política da autoridade governamental (INSTITUTO SEMEIA, 2015).

Para os casos de estudos internacionais, além de seguirem modelos de governança e gestão centralizado no governo, também observa-se um modelo compartilhado entre órgãos governamentais e não governamentais (e.g. ONGs e entidades privadas). De maneira geral, esse modelo apresenta maior flexibilidade, especialização e autonomia do que o modelo estatal, visto que os diversos órgãos necessitam trabalhar em conjunto para atingir os objetivos propostos (INSTITUTO SEMEIA, 2015).

Conforme ressaltado pelo Instituto Semeia (2015), ambos os modelos (estatal e não estatal) apresentam prós e contras, não existindo um modelo único a ser empregado em áreas protegidas, devendo ser analisado pelas autoridades governamentais as melhores opções a serem empregadas de acordo com cada realidade. No entanto, para as áreas protegidas urbanas, as quais são visivelmente mais vulneráveis quando comparadas com as áreas protegidas mais 
remotas, um modelo com maior flexibilidade e maior participação da sociedade nos processos de tomada de decisão mostrou-se mais efetivo, visto o cenário futuro incerto.

Observa-se que os casos de estudos internacionais adotam como um dos pilares de sua governança e gestão a participação ativa da sociedade civil. Isto é evidenciado quando se observa o engajamento da população nos processos decisórios, bem como em diversos projetos de integração, grupos de apoio e voluntários, atividades e reuniões dos Conselhos Consultivos realizadas nesses locais. Além disso, apesar de alguns dos casos apresentarem modelos centralizados no governo, verifica-se uma diversificação nas fontes de recursos financeiros, possibilitando maiores investimentos em comunicação e divulgação das informações. Também existem possibilidades de concessões, onde os concessionários recebem o direito de explorar uma atividade dentro da UC, em um período estabelecido através de um contrato com o Poder Público, com a obrigatoriedade de oferecer utilidades e serviços de qualidade para a população. Esses fatos, somado aos rígidos instrumentos legais (e.g. controle e fiscalização do Conselho da Rede Natura 2000 nos processos decisórios das gestões e amparo legal pelas Diretivas de Habitats e Aves), tornam o processo de tomada de decisão mais transparente e participativo.

Para os casos nacionais, observam-se limitações e dificuldades a serem enfrentadas pelas autoridades governamentais e gestões, as quais são altamente centralizadas. De maneira geral, observam-se baixos investimentos em estratégias de comunicação e as informações relacionadas aos processos decisórios são pouco divulgadas nos veículos de comunicação, não havendo transparência (evidências e comprovações dos fatos mencionados), resultando muitas vezes em incertezas sobre a realidade dessas áreas. Esses fatos podem ser explicados devido às limitações orçamentárias, onde as fontes de recursos financeiros são oriundas apenas dos órgãos governamentais, as quais não tem se mostrado suficientes para a realização de ações de manejo críticas. Além disso, o engajamento da sociedade nos Conselhos Consultivos ainda é incipiente quando comparado com os casos internacionais, onde grande parte das ações são realizadas para atender as demandas das câmaras técnicas.

Os horizontes de planejamento, referentes à etapa de planejamento estratégico, variam conforme os casos de estudos. Observa-se que os casos nacionais possuem uma visão de planejamento de 5 anos, ao passo que os internacionais possuem uma visão de 10 a 20 anos. Desse modo, caso as políticas ambientais de uma região sejam prejudicadas pelo cenário político decorrente, uma visão de longo prazo, delimitadas junto com a participação e apoio da 
sociedade civil, é fundamental para que estas consigam atingir as suas metas e objetivos, em prol do cenário futuro almejado.

Conforme mencionado por Pureza, Pellin e Pádua (2015), as prioridades na gestão das UCs brasileiras variam conforme os governantes do momento, não seguindo um plano ambiental de longo prazo. Não obstante, observam-se que em determinados casos de estudos (nacionais e internacionais) os gestores são indicados por nomeação política, o que pode comprometer a continuidade da execução dos planos e programas. Desse modo, não somente uma visão de longo prazo é necessária, mas também profissionais capacitados para agirem em situações conflituosas típicas de áreas urbanas e alianças com diferentes instituições e agências governamentais. Assim, as áreas protegidas não serão tão afetadas prejudicialmente conforme as mudanças de governança e as diferentes nomeações de profissionais.

As principais pressões e ameaças das áreas protegidas urbanas nacionais (PEJ, PEC, EERP, EEcA) e internacionais (LM, SF, PNZK) foram identificadas e avaliadas pelas suas gestões conforme a sua ocorrência, abrangência, impacto e permanência. As pressões e ameaças comuns aos sete casos de estudos são: desenvolvimento urbano do entorno; estradas e rodovias; mudanças climáticas; poluição atmosférica, hídrica, sonora e visual; espécies exóticas invasoras; disposição de resíduos; extração de recursos não madeireiros; conflitos entre humanos e animais selvagens; turismo e recreação; atividades industriais e crimes.

As pressões e ameaças encontradas apenas nos casos de estudos nacionais são: incêndios florestais; ocupações ilegais; atividades religiosas; disputas sobre o uso d'água; LTs e mineração. Já para os casos de estudos internacionais: atividades de pesca e transmissão de doenças entre animais silvestres. De maneira geral, esses resultados corroboram com os estudos de Trzyna (2014), o qual identifica as principais pressões e ameaças em áreas protegidas urbanas.

Apesar de cada área protegida apresentar particularidades e características únicas, elas se mostraram estar sendo impactadas por determinadas pressões e ameaças tipicamente urbanas. Além disso, muitas pressões e ameaças persistem, bem como os programas de monitoramento são afetados pela diminuição dos recursos financeiros. Logo, ressalta-se que um zoneamento adequado, somado a outras técnicas de gestão mostraram-se fundamentais para as áreas protegidas urbanas, principalmente para as categorias onde a visitação é permitida, conforme evidenciado nas análises de Trzyna (2014). Ainda segundo o autor, as áreas protegidas urbanas se beneficiam quando o seu zoneamento está integrado ao ordenamento do território fora dela, bem como quando há colaboração entre vários órgãos públicos e entidades sem fins lucrativos, que compartilham da mesma visão. 
Esses fatos são evidenciados em alguns dos casos de estudos internacionais, onde as gestões, em parceria com os municípios abrangentes, delimitaram o seu zoneamento conforme as facilidades e infraestruturas de seus territórios (e.g. criação de zonas recreativas no entorno das áreas protegidas, próximo facilidades dos municípios - transporte público, restaurantes, etc.). Já para os casos de estudos nacionais, de maneira geral, observa-se como uma tendência o desejo de diferentes setores da sociedade em modificar as zonas de amortecimento das UCs para categorias menos restritivas, não havendo uma vontade política para integrá-las às cidades.

Assim, verifica-se como fundamental considerar a existência de outras políticas, planos e programas setoriais e territoriais de nível nacional, regional e local para o estabelecimento das áreas protegidas urbanas. Apesar das limitações e dificuldades, nota-se que para todos os casos de estudos, seus planos de manejo foram baseados nos planos existentes dos territórios onde estão inseridos (e.g. planos diretores, ZEE e planos de ordenamento territorial diversos).

No que concerne o planejamento operacional, verificam-se que muitas das ações presentes nos programas de ação dos planos de manejo dos casos nacionais não vêm sendo implementadas. Isto pode ser explicado, conforme evidenciado por Fernandes, Hangae e Mota (2011), que muitas vezes as UCs, nesta etapa, planejam uma lista com diversas ações e diretrizes para serem executadas, mas muitas delas se mostram inviáveis na prática. Desse modo, é fundamental avaliar a quantidade de propostas submetidas na etapa de planejamento e a necessidade de priorizá-las conforme as maiores urgências. Além disso, observam-se que as etapas de diagnósticos demandam muito tempo e são onerosas, resultando em maiores dificuldades para o cumprimento dos programas de manejo.

Dos 7 casos de estudos nacionais e internacionais analisados, 4 equipes de gestão alegaram que o nível de recursos humanos de suas áreas protegidas não é suficiente para uma gestão adequada, atribuindo à falta de recursos financeiros para a contratação de funcionários. Observa-se também que apenas 1 caso de estudo alegou que os funcionários não possuem habilidades adequadas e nem oportunidades de capacitação e desenvolvimento apropriadas para realizar as ações de manejo críticas.

\section{Considerações Finais}

Existem diversas orientações e melhores práticas em áreas protegidas propostas pela IUCN, as quais podem ser aplicadas, em especial, às áreas protegidas urbanas, visto às inúmeras adversidades do seu entorno urbno. Desse modo, para que essas áreas cumpram com os seus objetivos de conservação, verificam-se como fundamentais a adoção de algumas práticas 
adequadas de governança e gestão. De maneira geral, observa-se que as autoridades governamentais devem seguir cinco princípios visando uma boa governança em áreas protegidas urbanas:

- Legitimidade e voz (e.g. mediar os interesses e conflitos em áreas protegidas urbanas fazendo-se prevalecer os interesses coletivos; fornecer orientações claras e garantir a participação da sociedade nos processos decisórios, havendo transparência nas informações e decisões);

- Direção (e.g. definir uma visão estratégica, levando em consideração o desenvolvimento humano e as complexidades históricas, culturais e sociais; seguir os acordos firmados);

- Desempenho (e.g. garantir a boa governança através da aplicação de avaliações de efetividade periódicas; implantar um processo de aprendizagem colaborativa; fornecer capacidade adequada para os profissionais envolvidos;

- Responsabilidade (e.g. garantir a transparências nos processos; encorajar o engajamento da sociedade civil e da mídia);

- Equidade e direitos (e.g. aplicar os instrumentos legais de maneira justa e imparcial).

Portanto, os formuladores de políticas devem reconhecer a importância das áreas protegidas urbanas e aplicar os princípios destacados, para que assim essas áreas estejam amparadas legalmente e asseguradas em boas práticas de governança frente ao cenário urbano. Complementarmente às boas práticas de governança, as áreas protegidas urbanas também necessitam de práticas de gestão adequadas para que estas áreas consigam lidar com os diversos problemas, expostas a seguir:

- A gestão deve ser dinâmica, ativa e planejada, seguindo concepções racionais, adaptativas e participativas propostas pela IUCN;

- O planejamento da área protegida urbana deve conter elementos estratégicos, táticos e operacionais, visando se atingir um cenário futuro de equilíbrio da conservação com o desenvolvimento urbano do seu entorno;

- No âmbito das estratégias operacionais, a gestão das áreas protegidas urbanas devem levar em consideração às pessoas, lugares e instituições que se relacionam com as áreas protegidas urbanas, bem como devem promover e melhorar as suas gestões;

- Devem possuir um plano de manejo adequado, o qual conterá as principais diretrizes e normas a serem seguidas; 
- Os diversos profissionais devem ser proativos, com habilidades de comunicação para lidarem com os diversos atores envolvidos (e.g. negociar com diferentes stakeholders e se comunicar com as comunidades), capacitados a lidar com os problemas e desafios locais e coordenar os diferentes recursos;

- Devem possuir infraestrutura, recursos humanos e financeiros suficientes para uma gestão adequada.

Por fim, tanto os responsáveis pela governança como os responsáveis pela gestão das áreas protegidas urbanas devem trabalhar em conjunto para conscientizar a sociedade urbana sobre a importância dessas áreas, visando adquirir mais aliados para enfrentarem os diversos desafios atuais e futuros. 


\section{CONCLUSÕES}

Apesar de cada área protegida urbana apresentar particularidades e realidades distintas, foram verificadas pressões e ameaças tipicamente urbanas, comuns aos sete casos de estudos, tais como: desenvolvimento urbano do entorno; estradas e rodovias; mudanças climáticas; poluição atmosférica, hídrica, sonora e visual; espécies exóticas invasoras; disposição de resíduos; extração de recursos não madeireiros; conflitos entre humanos e animais selvagens; turismo e recreação; atividades industriais e crimes.

Observou-se que todos os casos de estudos buscaram implementar procedimentos para mitigação das principais pressões e ameaças que ocorrem em seus territórios. Logo, verificamse a adoção de seis tipos de ações de conservação em áreas protegidas urbanas, tais como as ações de:

- Proteção: são direcionadas para a proteção dos recursos das UCs frente às atividades incompatíveis com os seus objetivos, infrações ambientais e demais atividades que possam comprometer a integridade do seu patrimônio (e.g. fiscalização e monitoramento);

- Manejo: práticas e técnicas de manejo dos recursos naturais e culturais, no sentido de garantir a dinâmica dos ecossistemas e possibilitar a manutenção da biodiversidade presentes nas UCs (e.g. controle de espécies exóticas invasoras);

- Operacionalização: buscam garantir a funcionabilidade da UC, provendo-a de infraestruturas gerais, equipamentos, recursos humanos, entre outros (e.g. articulação com diferentes instituições);

- Integração: visam envolver e integrar os indivíduos que compõem os territórios onde as UCs estão inseridas, de modo a fortalecer as relações entre estes e aumentar a consciência sobre a importância em se manter essas áreas (e.g. sensibilização ambiental, comunicação e divulgação);

- Uso público: apresentam como objetivo ordenar, direcionar e orientar o uso da UC pelo público, bem como sensibilizar os visitantes sobre as questões ambientais e o papel das UCs (e.g. promoção de atividades turísticas e recreativas de baixo impacto ambiental);

- Conhecimento: proporcionam subsídios para a proteção e o manejo dos recursos naturais, sendo uma das principais ferramentas para o estabelecimento das ações de manejo (e.g. estudos, pesquisas científicas e monitoramento ambiental). 
Contudo, foi possível observar que algumas variáveis prejudicam o cumprimento dos objetivos das áreas protegidas urbanas, tais como: recursos humanos e financeiros insuficientes, baixa transparência e participação social nos processos de tomada de decisão. Em suma, os modelos de governança centralizados nos governos são menos flexíveis quando comparado aos demais, possuindo limitações gerenciais e orçamentárias, com grande ingerência política da autoridade governamental.

Também foi possível observar que as fontes de recursos financeiros oriundas apenas dos órgãos governamentais não têm se mostrado suficientes para a realização de ações de manejo críticas. Desse modo, os casos de estudos internacionais, que possuem um modelo de governança compartilhada (entre órgãos governamentais e não governamentais) e com o uso de concessões, permitem uma diversificação nas fontes de recursos financeiros, possibilitando maiores investimentos nessas áreas e consequentemente, uma maior flexibilidade, especialização e autonomia do que o modelo estatal.

Além disso, verifica-se como fundamental promover o empoderamento dos conselhos das UCs urbanas para que estes funcionem adequadamente como fóruns de discussão e participação, e não apenas para atender as demandas mais urgentes das câmaras técnicas. Desse modo, observou-se que os casos de estudos internacionais investem no engajamento da população, através de diferentes estratégias de sensibilização, comunicação e divulgação das questões que envolvem as UCs, tornando o processo de decisão transparente e participativo. Nesse sentido, para que a sociedade civil possa ter maior autonomia nos processos de decisão das UCs urbanas, entende-se como importante a existência de reuniões periódicas e sistemáticas e que os conselhos consultivos sejam também deliberativos, descentralizando a figura do gestor como único responsável pela área. Assim, o Estado não se afasta das suas obrigações, mas propicia a sociedade civil uma efetiva participação sobre as decisões que envolvem a conservação do seu território, contribuindo para a conservação desses locais e para a formação de uma rede ampla de apoio público.

Nesse sentido, a partir da constatação de impactos prejudiciais às UCs e da possibilidade de novos efeitos negativos para os próximos anos, torna-se fundamental para que as áreas protegidas urbanas conciliem a conservação da biodiversidade com o desenvolvimento urbano do entorno, atenderem as orientações propostas pela IUCN.

Desse modo, foi possível verificar recomendações diversas a respeito de dois componentes fundamentais que sustentam essas áreas: governança e gestão. Dentre as propostas para governança, destacam-se cinco princípios que a IUCN aconselha as autoridades governamentais a seguirem, tais como: I) legitimidade e voz; II) direção; III) desempenho; IV) 
responsabilidade e V) equidade e direitos. Dentre as práticas de gestão adequadas, destacamse: I) tornar a gestão dinâmica, ativa e planejada, seguindo concepções racionais, adaptativas e participativas; II) adotar elementos estratégicos, táticos e operacionais para o planejamento da área protegida urbana; III) considerar as pessoas, lugares e instituições que se relacionam com as áreas protegidas urbanas durante o processo de gestão, bem como promover e melhorar as suas gestões; IV) implementar planos de manejos adequados; V) garantir que os profissionais sejam proativos, com habilidades de comunicação, capacitados a lidar com as adversidades e coordenar os diferentes recursos; e por fim, VI) garantir infraestrutura, recursos humanos e financeiros suficientes para uma gestão adequada. Logo, com o empoderamento da sociedade civil nos processos de tomada de decisão que envolvem as UCs urbanas, e atribuindo-a maiores responsabilidades, a população poderá de fato contribuir para que os princípios de governança e as práticas de gestão adequadas sejam efetivamente seguidas.

Conclui-se que áreas protegidas urbanas devem estar integradas aos planos, programas e projetos setoriais dos territórios em que estão inseridas, através de legislações e diretrizes específicas, bem como a partir do estabelecimento de parcerias com as instituições próximas. Para tanto, instrumentos de planejamento mais estratégicos (tais como a Avaliação Ambiental Estratégica - AAE) podem contribuir para a integração da biodiversidade urbana nos planejamentos territoriais.

Outra questão importante é a ZA das UCs urbanas. Para que cumpram com o seu papel de minimizar os impactos negativos, as equipes de gestão devem constantemente monitorar e fiscalizar as atividades que ali ocorrem, evitando que ocorra a degradação no interior da área protegida. A criação de UCs de uso sustentável (e.g. APAs, as quais possuem como objetivo a compatibilização da conservação da natureza com o uso sustentável de parcela dos seus recursos naturais) no entorno imediato das UCs peri-urbanas (isto é, aquelas que não estão totalmente cercadas pelo desenvolvimento urbano do entorno), podem trazer um maior regramento das atividades antrópicas que possam prejudicar esses locais. Ademais, também é fundamental a promoção de maiores conexões com outras áreas naturais, sejam estas através da criação de mosaicos, isto é, conjunto de UCs justapostas ou sobrepostas, e outras áreas protegidas públicas ou privadas, garantindo que as funções e consequentes serviços ambientais nesses locais sejam preservados. 
Nesse contexto, para o cumprimento das propostas discutidas, é imprescindível que os governantes incorporem em suas legislações a definição de UCs urbanas, reconhecendo a sua importância e garantindo com que estas áreas recebam maiores atenções, visto as inúmeras adversidades que enfrentam.

Em suma, conservar a biodiversidade urbana é fundamental para o bem-estar geral da população urbana. Logo, as orientações propostas pela IUCN, isto é, a adoção de práticas de governança e gestão adequadas, exequíveis, dinâmicas e participativas em áreas protegidas urbanas, auxiliam na manutenção de ecossistemas saudáveis, os quais formam a espinha dorsal de um futuro mais sustentável. 


\section{REFERÊNCIAS ${ }^{113}$}

AGUIAR-SILVA, F. H.; BONILlA, O. H.; NASCIMENTO, C. A. Avaliação da viabilidade e efetividade das unidades de conservação integral no Ceará, Brasil. Revista Caatinga, v. 24, n. 1, p. 48-56, 2010.

ALVEY, A. A. Promoting and preserving biodiversity in the urban forest. Urban Forestry \& Urban Greening, v.5, p.195-201, 2006.

ANGEL, S.; SHEPPARD, S.; CIVCO, D.; BUCKLEY, R.; CHABAEVA, A.; GITLIN, L.; KRALEY, A.; PARENT, J.; PERLIN, M. The Dynamics of Global Urban Expansion. Transport and Urban Development Department. The World Bank: Washington, DC, 2005.

ANTROP, M. Landscape change and the urbanization process in Europe. Landscape and urban planning, v. 67, n. 1, p. 9-26, 2004.

ARCE, P. A.; PENDlOSKI, C. J. S.; OLIVEIRA, R. B. de.; GALLARDO, A. L. C. F.; RUIZ, M. S. Conflitos socioambientais em unidades de conservação em áreas urbanas: o caso do Parque Tizo, São Paulo. HOLOS, v. 1, p. $75-85,2014$.

ARROYAVE, M. D. P.; GÓMEZ, C.; GUTIÉRREZ, M. E.; MÚNERA, D. P.; ZAPATA, P. A.; VERGARA, I. C.; ANDRADE, L. M.; RAMOS, K. C. Impactos de las carreteras sobre la fauna silvestre y sus principales medidas de manejo. Revista EIA, n.5, p.45-57. 2006.

ATMIŞ, E.; ÖZDEN, S.; LISE, W. Urbanization pressures on the natural forests in Turkey: an overview. Urban Forestry \& Urban Greening, v. 6, n. 2, p. 83-92, 2007.

AUER, A. M. S. Avaliação das unidades de conservação do estado do Paraná e da viabilidade de um Sistema de Unidades de Conservação. 1995. 150 p. Dissertação (Mestrado em Ciências Florestais) Universidade Federal do Paraná, Curitiba, 1995.

BALMFORD, A.; BERESFORD, J.; GREEN, J.; NAIDOO, R.; WALPOLE, M.; MANICA, A. A global perspective on trends in nature-based tourism. PLoS Biology. v.7, n.6, 2009.

BALOTTA, P. T.; BITTAR, O. Y. Indicadores ambientais para o monitoramento de parques urbanos. InterfacEHS - Revista de Saúde, Meio Ambiente e Sustentabilidade, v.4, n.2, 2009.

BARBER, C.V.; MILLER, K. R.; BONESS, M. Securing Protected Areas in the Face of Global Change: Issues and Strategies. Gland: World Commission on Protected Areas - IUCN, 2004.

BARDIN, I. Análise de conteúdo. Lisboa: Edições Setenta, 1994. 226 p.

BEHR, M. von.; PEIXOTO, S. L. Unidades de Conservação Urbanas e Periurbanas: por uma gestão e política pública diferenciada. Versão preliminar. Brasília: Instituto Chico Mendes de Conservação da Biodiversidade ICMbio. 2015.94 p.

BELLARD C.; BERTELSMEIER C.; LEADLEY P.; THUILLER W.; COURCHAMP F. Impacts of climate change on the future of biodiversity. Ecology Letters, v.15, p. 365-377, 2012.

BENINI, S. M.; MARTIN, E. S. Decifrando as áreas verdes públicas. Revista Formação, v. 2, n.17, p. 63-80, 2010.

\footnotetext{
${ }^{113}$ De acordo com a Associação Brasileira de Normas Técnicas (ABNT NBR 6023). A presente dissertação segue as Diretrizes para Apresentação de Dissertações e Teses da USP: parte I (ABNT)/ Sistema Integrado de Bibliotecas da USP. $3^{\text {a }}$ edição Revisada, ampliada e modificada, 2016. Disponível em: < http://www.livrosabertos.sibi.usp.br/portaldelivrosUSP/catalog/view/111/95/491-1>. Acesso em: Jan 2017.
} 
BIOTA FAPESP. Desenvolvido pela Fundação de Amparo à Pesquisa do Estado de São Paulo. Disponível em: <http://www.biota.org.br/>. Acesso em: Abr 2017.

BOLUND, P., HUNHAMMAR, S. Ecosystem services in urban areas. Ecological Economics, v. 29, n. 2, p.293301, 1999.

BONANNO, G. Alien species: to remove or not to remove? That is the question. Environmental Science \& Policy, v. 59, p. 67-73, 2016.

BONTEMPO, G. C.; LIMA, G. S.; RIBEIRO, G. A.; DOULA, S. M.; JACOVINE, L. A. G. (2011). Registro de Ocorrência de Incêndio (ROI): evolução, desafios e recomendações. Biodiversidade Brasileira, n. 2, p. 247-263, 2011.

BORGES, S. H.; IWANAGA, S.; MOREIRA, M.; DURIGAN, C. C. Uma análise geopolítica do atual sistema de unidades de conservação na Amazônia Brasileira. Política Ambiental, v. 4, p. 3-42, 2007.

BORRINI-FEYERABEND, G.; DUDLEY, N.; JAEGER, T., LASSEN B.; BROOME, N. P.; PHILLIPS, A.; SANDWITH, T. Governance of Protected Areas: From understanding to action. IUCN, Gland.2013.

BORRINI-FEYERABEND, G.; HILL, R. Governance for the conservation of nature. In: WORBOYS, G. L.; LOCKWOOD, M.; KOTHARI, A.; FEARY, S.; PULSFORD, I. (eds). Protected Area Governance and Management. ANU Press: Canberra, 2015, p. 169-206,

BRASIL. Lei no 9.985, de 18 de julho de 2000. Regulamenta o art. 225, § 1o, incisos I, II, III e VII da Constituição Federal, institui o Sistema Nacional de Unidades de Conservação da Natureza e dá outras providências. Diário Oficial da União. Brasília, DF, 19 jul. 2000.

BRASIL. Lei $n^{\circ} 11.516$, de 28 de agosto de 2007. Dispõe sobre a criação do Instituto Chico Mendes de Conservação da Biodiversidade - Instituto Chico Mendes; altera as Leis nos 7.735, de 22 de fevereiro de 1989, 11.284, de 2 de março de 2006, 9.985, de 18 de julho de 2000, 10.410, de 11 de janeiro de 2002, 11.156, de 29 de julho de 2005, 11.357, de 19 de outubro de 2006, e 7.957, de 20 de dezembro de 1989; revoga dispositivos da Lei no 8.028, de 12 de abril de 1990, e da Medida Provisória no 2.216-37, de 31 de agosto de 2001; e dá outras providências. Diário Oficial da União. Brasília, DF, 28 ago. 2007.

BRITO, F. O deslocamento da população brasileira para as metrópoles. Estudos Avançados, v.20, n.57, 2006.

BUCKLEY, R. C. Environmental Impacts of Ecotourism. New York, USA: CABI, 2004.

CADASTRO NACIONAL DE UNIDADES DE CONSERVAÇÃO URBANA (CNUC). Desenvolvido pelo Ministério do Meio Ambiente. Disponível em: <http://www.mma.gov.br/acessibilidade>. Acesso em: Abr 2016.

CARDOSO, P. M. Conflitos socioambientais em áreas protegidas: interesses e estratégias nas disputas pela legitimidade na redefinição do Parque Estadual Delta do Jacuí-RS. 2006. Dissertação (Mestrado em Desenvolvimento Rural) - Faculdade de Ciências Econômicas, Universidade Federal do Rio Grande do Sul, Porto Alegre, 2006.

CAREY, C.; DUDLEY, N.; STOLTON, S. Squandering paradise: the importance and vulnerability of the world's protected areas. Gland, Switzerland: WWF, 2000.

CARRUS, G.; SCOPELliti, M.; LAFORTEZZA, R.; COLANGELO, G.; FERRINI, F.; SALBITANO, F.; AGRIMI, M.; PORTOGHESI, L.; SEMENZATO, P.; SANESI, G.; Go greener, feel better? The positive effects of biodiversity on the well-being of individuals visiting urban and peri-urban green areas. Landscape and Urban Planning, v. 134, p. 221-228, 2015.

CAVALHEIRO, F., NUCCI, J. C., GUZZO, P., \& ROCHA, Y. T. Proposição de terminologia para o verde urbano. Boletim Informativo Sociedade Brasileira de Arborização Urbana, v.7, n.3, p.7, 1999.

CERQUEIRA, R.; BRANT, A.; NASCIMENTO, M. T.; PARDINI, R. Fragmentação: alguns conceitos. In: RAMBALDI, D. M.; OLIVEIRA, D. A. S. Fragmentação de ecossistemas: causas, efeitos sobre a biodiversidade e recomendações de políticas públicas. Brasília: MMA/SBF, 2003. p. 24-40. 
CHAPE, S.; HARRISON, J.; SPALDING, M.; LYSENKO, I. Measuring the extent and effectiveness of protected areas as an indicator for meeting global biodiversity targets. Philosophical Transactions of the Royal Society B: Biological Sciences, v. 360, n. 1454, p. 443-455, 2005.

CONNER, N. Some benefits of protected areas for urban communities: A view from Sydney, Australia. In: TRZYNA, T. The Urban Imperative. Sacramento, California: California Institute of Public Affairs, 2005. p. 3443.

CONVENTION ON BIOLOGICAL DIVERSITY (CBD). Alien Species that Threaten Ecosystems, Habitats or Species. United Nations, Article 8(h), 2008.

Strategic Plan for Biodiversity 2011-2020 and the Aichi Targets. Montreal: Secretariat of the Convention on Biological Diversity, 2011.

CORVALAN, C.; HALES, S.; MCMICHAEL, A. Ecosystems and human well-being: General Synthesis - a report of the Millennium Ecosystem Assessment. Washington, DC: Island Press, 2005.

CostA, N. M. C. da; CostA, V. C. da; VAliM, C. B. de; SOUZA, A. C. C. C. de; SALES, A. C. de G. Significado e importância da zona de amortecimento de unidades de conservação urbanas: o exemplo do entorno das áreas legalmente protegidas da cidade do Rio de Janeiro. Geo UERJ, v.1, n.17, pp. 95-104, 2007.

CRAWHALL, N. Social and economic influences shaping protected areas. In: WORBOYS, G. L.; LOCKWOOD, M.; KOTHARI, A.; FEARY, S. PULSFORD, I. (eds). Protected Area Governance and Management. Canberra: ANU Press, 2015. p. 117-144.

CROUZEILLES, R.; LORINI, M. L.; GRELLE, C. E. V.. The importance of using sustainable use protected areas for functional connectivity. Biological conservation, v. 159, p. 450-457, 2013.

CRUTZEN, P. J. Geology of mankind. Nature, v. 415, n. 6867, p. 23-23, 2002.

CUMMING, G. S. The relevance and resilience of protected areas in the Anthropocene. Anthropocene, v. 13, p. 46-56, 2016.

DEARBORN, D. C.; KARK, S. Motivations for conserving urban biodiversity. Conservation biology, v. 24, n. 2, p. 432-440, 2010.

DEBETIR, E. Gestão de unidades de conservação sob influência de áreas urbanas: diagnóstico e estratégias de gestão na Ilha de Santa Catarina. 2006. 247 p. Tese (Doutorado em Engenharia Civil) Universidade Federal de Santa Catarina, Florianópolis, 2006.

DESJARDINS, M.J.; TELMER, K.; BEAUCHAMP, S. Apportioning atmospheric pollution to Canadian and American sources in Kejimkujik National Park, Nova Scotia, using Pb isotopes in precipitation. Atmospheric Environment, v. 38, n. 39, p. 6875-6881, 2004.

DIEGUES, A. C. S. O mito moderno da natureza intocada. São Paulo: Hucitec, 1996.

DUDLEY, N.; STOLTON, S. The role of forest protected areas in supplying drinking water to the world's biggest cities. In: TRYZNA, T. The Urban Imperative. Sacramento, California: California Institute of Public Affairs, 2005, p. 27-33.

DUDLEY, N. Guidelines for Applying Protected Area Management Categories. Gland, Switzerland: IUCN, 2008.

DURÁN, A. P.; RAUCH, J.; GASTON, K. J. Global spatial coincidence between protected areas and metal mining activities. Biological conservation, v. 160, p. 272-278, 2013.

DURIGAN, G. Estação Ecológica de Assis: Plano de Manejo. São Paulo: Instituto Florestal. 2010. 171 p. 
ERVIN, J. Metodologia para Avaliação Rápida e a Priorização do Manejo de Unidades de Conservação (RAPPAM). Gland, Suíça: WWF, 2003.

EUROPEAN COMISSION. Managing Natura 2000 Sites: the provisions of Article 6 of "Habitats" Directive 92/43/EEC. Luxembourg: Office for Official Publications of the European Communities, 2000. 73p.

Invasive Alien Species. Nature and Biodiversity. Luxembourg: Publications Office of the European

Union. Disponível em:

<http://ec.europa.eu/environment/pubs/pdf/factsheets/Invasive\%20Alien\%20Species/Invasive_Alien_EN.pdf〉, 2010. 16p.

Being wise with waste: the EU's approach to waste management. Luxembourg: Publications Office of
the
European http://ec.europa.eu/environment/waste/pdf/WASTE\%20BROCHURE.pdf>, 2010. 20p.

Cleaner air for all. Luxembourg: Publications Office of the European Union. Disponível em: <http://ec.europa.eu/environment/pubs/pdf/factsheets/air/en.pdf>. 2013. 4p.

Establishing conservation measures for Natura 2000 Sites. Luxembourg: Publications Office of the European Union, 2014. 43p.

Environment. Desenvolvido por: European Union. Disponível em: < http://ec.europa.eu/environment/basics/home_en.htm>. Acesso em: Out 2016.

• Commission's DG Environment. $\quad$ Disponível em:

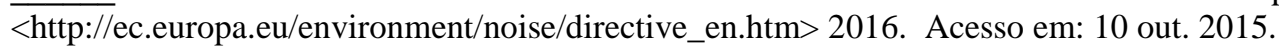

EUROPEAN ENVIRONMENTAL AGENCY (EEA), 2015. Brussels. Disponível em <http://ec.europa.eu/environment/nature/natura2000/index_en.htm>. Acesso em: 10 out. 2015.

FARIA, H. H. de. Eficácia de gestão de Unidades de Conservação gerenciadas pelo Instituto Florestal de São Paulo, Brasil. 2004. 385p. Tese (Doutorado em Geografia). Universidade Estadual "Júlio de Mesquita Filho", Presidente Prudente, São Paulo. 2004.

. Aplicação do EMAP e rotinas estatísticas complementares na avaliação da eficácia de gestão de unidades de conservação do Estado de São Paulo, Brasil. Revista Ciências do Ambiente On-Line, v. 2, n. $2,2006$.

FERNANDES, C. H. V.; HANGAE, L. L. M.; MOTA, L. C. Roteiro Metodológico de Planejamento: Parque Nacional, Reserva Biológica, Estação Ecológica. Brasília: Instituto Brasileiro do Meio Ambiente e dos Recursos Naturais Renováveis - IBAMA, 2011. 133p.

FONSECA. G. A.B.; PINTO, L. P. S.; RYLANDS, A. B. Biodiversidade e unidades de conservação. Conservation International do Brasil. Paraná, v. 1, p. 189-209. 1997.

FONTOURA, L. M.; MEDEIROS, R. J. de; ADAMS, L. W. Turismo, Pressões e Ameaças para a Conservação da Biodiversidade em Parques Nacionais do Brasil e Estados Unidos. CULTUR-Revista de Cultura e Turismo, v. 10, n. 1, p. 35-53, 2016.

GALANTE, M. L. V.; BESERRA, M. M. L.; MENEZES, E. O. Roteiro Metodológico de Planejamento: Parques Nacionais, Reserva Biológica, Estação Ecológica. Brasília: Ministério do Meio Ambiente, 2002. 136p.

GELDMANN, J.; COAD, L.; BARNES, M.; CRAIGIE, I. D.; HOCKINGS, M.; KNIGHTS K.; LEVERINGTON, F.; CUADROS, I. C.; ZAMORA, C.; WOODLEY, S.; BURGESSA, N. D. Changes in protected area management effectiveness over time: a global analysis. Biological Conservation, v. 191, p. 692-699, 2015.

GOMES, M. A. S.; SOARES, B. R. Vegetação nos centros urbanos: considerações sobre os espaços verdes em cidades médias brasileiras. Estudos Geográficos, v. 1, n.1, p. 19-29, 2003.

GONÇALVES, A. R.; FERNANDES, C. H. V.; PENTEADO, D.; VELOSO, V. S. Roteiro Metodológico para Elaboração de Planos de Manejo. Brasília: Ministério do Meio Ambiente, 2009. 57 p. 
GOVERNO DO ESTADO DE SÃO PAULO. Portal do Governo do Estado de São Paulo. Disponível em: <http://www.saopaulo.sp.gov.br/index.php>. Acesso em: 10 de Agosto de 2015.

GRAHAM, J.; AMOS, B.; PLUMPTRE, T. Governance principles for protected areas in the 21st century, a discussion paper. Institute on Governance in collaboration with Parks Canada and Canadian International Development Agency, Ottawa, 2003.

GUIMARÃES, E., PELLIN, A. BiodiverCidade: desafios e oportunidades na gestão de áreas protegidas urbanas. São Paulo: Matrix, 2015. 199p.

GULEZ, S. A method for evaluating areas for national park status. Environmental Management, v.16, n.6, p.8118, 1992.

HITT, M. A.; BLACK, S.; PORTER, L. W. Management. 3rd ed. Pearson Education, Upper Saddle River, NJ. 2011.

HOCKINGS, M.; STOLTON, S.; LEVERINGTON, F.; DUDLEY, N.; COURRAU, J. Evaluating Effectiveness: A Framework for Assessing the Management of Protected Areas. Gland, Switzerland: IUCN, 2nd edition, 2006. $105 \mathrm{p}$.

HÖLKER, F.; T. MOSS; B. GRIEFAHN; W. KLOAS; C. C. VOIGT; D. HENCKEL; A. HÄNEL; P. M. KAPPELER; S. VÖLKER; A. SCHWOPE; S. FRANKE; D. UHRLANDT; J. FISCHER; R. KLENKE; C. WOLTER; K. TOCKNER. The dark side of light: a transdisciplinary research agenda for light pollution policy. Ecology and Society, v. 15, n.4. 2010.

IBAMA. Relatório de Ocorrência de Incêndios Florestais. Documento Técnico. São Paulo: PREVFOGO, 2002.

INSTITUTO SEMEIA. Modelos de gestão aplicáveis às unidades de conservação do Brasil. São Paulo: Semeia, 2015. 59 p.

INTERNATIONAL UNION FOR CONSERVATION OF NATURE (IUCN) and UNITED NATIONS ENVIRONMENT PROGRAMME WORLD CONSERVATION MONITORING CENTRE (UNEP-WCMC). The World Database on Protected Areas. Cambrigde: UNEP-WCMC. Disponível em: <https://www.protectedplanet.net/>. Acesso em: Out 2016.

Protected Planet Report 2016. Cambridge, UK and Gland, Switzerland, 2016.

KOTCHETKOFF-HENRIQUES, O. Caracterização da vegetação natural em Ribeirão Preto, SP: Bases para a conservação. 2003. 270p. Tese (Doutorado em Ciências) Universidade de São Paulo. 2003.

KOTHARI, A.; COONEY, R.; HUNTER, D.; MACKINNON, K.; MULLER, E.; NELSON, F.; OLI, K. P.; PANDEY, S.; RASHEED, T.; VAVROVA, L. Managing resource use and development. In: WORBOYS, G. L.; LOCKWOOD, M.; KOTHARI, A.; FEARY, S. PULSFORD, I. (eds). Protected Area Governance and Management. Canberra: ANU Press, 2015. p. 789-822.

KOVARIK, I. Novel urban ecosystems, biodiversity, and conservation. Environmental Pollution, v.159, n. 8, p.1974-1983, 2011.

KREIMER E.; JUNGMEIER, M.; HUBER, M.; KÖSTL T. City meets Nature. Im Auftrag von: Magistrat der Stadt Klagenfurt am Wörthersee und Amt der Kärntner Landesregierung Naturpark, Bearbeitung: E.C.O. Institut für Ökologie, Klagenfurt, 85p. 2013.

LEMOS DE SÁ, R. M.; FERREIRA, L. M. Áreas protegidas ou espaços ameaçados: o grau de implementação e a vulnerabilidade das Unidades de Conservação federais brasileiras de uso indireto. Brasília, DF: WWF, 2000.

LEONEL, C.; NALON, M. A.; THOMAZIELlO, S. Estação Ecológica de Ribeirão Preto: Plano de Manejo. São Paulo: Fundação Florestal do Estado de São Paulo. 2010. 266p. 
LEONEL, C. Parque Estadual da Cantareira: Plano de Manejo. São Paulo: Fundação Florestal do Estado de São Paulo. 2009. 586 p.

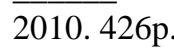

Parque Estadual do Jaraguá: Plano de Manejo. São Paulo: Fundação Florestal do Estado de São Paulo.

LEVERINGTON, F.; HOCKINGS, M; PAVESE, H.; COSTA, K. L.; COURRAU, J. Management effectiveness evaluation in protected areas - a global study. Supplementary report n.1: Overview of approaches and methodologies. The University of Queensland, Gatton, TNC, WWF, IUCN-WCPA, Australia, 2008.

LEVERINGTON F.; COSTA, K. L.; COURRAU J.; PAVESE H.; NOLTE C.; MARR M.; COAD L.; BURGESS N.; BOMHARD B.; HOCKINGS M. Management effectiveness evaluation in protected areas - a global study. World Commission on Protected Areas. $2^{\mathrm{a}}$ ed, 101 p. $2010 \mathrm{a}$.

LEVERINGTON, F.; COSTA, K., L.; PAVESE, H.; LISLE, A.; HOCKINGS, M. A Global Analysis of Protected Area Management Effectiveness. Environmental Management, v. 46, n.5, p. 685-698, 2010 b.

LI, W.; HAN, N. Ecotourism Management in China’s nature reserves. Ambio, v.30, p. 62-63, 2001.

LIMA, A. M. L. P.; CAVAlHEIRO, F.; NUCCI, J. C.; SOUSA, M. A. de L. B.; FIALHO, N. de O.; DEL PICCHIA, P. C. D. Problemas de utilização na conceituação de termos como espaços livres, áreas verdes e correlatos. In: II Congresso Brasileiro de Arborização Urbana, 1994, São Luís/MA. Anais...São Luís/MA: II Congresso Brasileiro de Arborização Urbana, 1994. p. 539-553.

LIMA, G. S.; RIBEIRO, G. A.; GONÇALVES, W. Avaliação da efetividade de manejo das unidades de conservação de proteção integral em Minas Gerais. Revista Árvore, v. 29, n. 4, p. 647-653, 2005.

LINDENMAYER, D.B.; FRANKLIN, J.F.; FISCHER, F.General management principles and a checklist of strategies to guide forest biodiversity conservation. Biological Conservation, v.131, p.433-445, 2006.

LOCKWOOD, M.; WORBOYS, G. L.; KOTHARI, A. (eds). Protected Area Management: a global guide. London: Earthscan, 2006. 802p.

LUDKA, M. Avaliação da efetividade do manejo de unidades de conservação no Brasil. 2012, 154p. Dissertação (Mestrado em Gestão Ambiental) Universidade Federal Fluminense, 2012.

MACE, G. M.; REYNOLDS, J. D. Exploitation as a conservation issue. Conservation of exploited species, v. 6 , p. $1,2001$.

MARTINEZ-JUAREZ, P.; CHIABAI, A.; TAYLOR, T.; GÓMEZ, S. Q. The impact of ecosystems on human health and well-being: A critical review. Journal of Outdoor Recreation and Tourism, v. 10, p. 63-69, 2015.

MASCIA, M.B.; PAILLER, S. Protected area downgrading, downsizing, and degazettement (PADDD) and its conservation implications. Conservation Letters, v.4, n.1, p. 9-20. 2011.

MATHUR, V. B.; ONIAL, M.; MAUVAIS, G. Managing threats. In: WORBOYS, G. L.; LOCKWOOD, M.; KOTHARI, A.; FEARY, S. PULSFORD, I. (eds). Protected Area Governance and Management. Canberra: ANU Press, 2015, p. 473-494.

MAZZEI, K.; COLESANTI, M. T. M.; SANTOS, D. G. dos. Áreas verdes urbanas, espaços livres para o lazer. Sociedade \& Natureza, v. 19, n.1, p.33-43, 2007.

MCDONALD, R.I. Global urbanization: Can ecologists identify a sustainable way forward? Frontiers in Ecology and the Environment, v. 6, n. 2, p. 99-104, 2008

MCDONALD, R. I.; KAREIVA P.; FORMAN R. T. The implications of current and future urbanization for global protected areas and biodiversity conservation. Biological conservation, v. 141, n. 6, p. 1695-1703, 2008. 
MCDONALD, R. I.; FORMAN, R. T.; KAREIVA, P.; NEUGARTEN, R.; SALZER, D.; FISHER, J. Urban effects, distance, and protected areas in an urbanizing world. Landscape and Urban Planning, v. 93, n. 1, p. 63$75,2009$.

MCKINNEY, M., L. Urbanization, Biodiversity, and Conservation. BioScience, v. 52, n. 10, p. 883-890, 2002.

MCNEELY, J. A. Cities, nature, and protected areas: a general introduction. Symposium on Natural Areas in Conurbations and on City Outskirts, Barcelona, Spain. 1995. p. 25-27.

Cities and protected areas: an oxymoron or a partnership? Parks, v. 11, n. 3, p. 1-3, 2001.

MCPHERSON, E. G. Cooling urban heat islands with sustainable landscapes. pp. 151-171. In: PLATT, R. H.; ROWNTREE, R. A.; MUICK, P. C. (eds.). The Ecological City: Preserving and Restoring Urban Biodiversity. Amherst: University of Massachusetts Press, 1994. p. 151-171.

MEDEIROS, M. B. Manejo do fogo em unidades de conservação do cerrado. Boletim do Herbário Ezechias Paulo Heringer, v. 10, p. 75-88, 2002.

MEDEIROS, R. Evolução das tipologias e categorias de áreas protegidas no Brasil. Ambiente \& Sociedade, v. 9 , n. 1, p. 41-64, 2006.

MEDEIROS, R.; IRVING, M.; GARAY, I. A proteção da natureza no Brasil: evolução e conflitos de um modelo em construção. RDE-Revista de Desenvolvimento Econômico, v. 6, n. 9, 2007.

MEDEIROS, R.; YOUNG, C. E. F.; PAVESE, H. B.; ARAÚJO, F. F. S. Contribuição das unidades de conservação brasileiras para a economia nacional: sumário Executivo. Brasília: UNEP-WCMC, 2011.

MELAZO, G. C.; COLASANTI, M. T. M. Parques urbanos: importantes espaços verdes na dinâmica ambiental das cidades. In: Simpósio Regional de Geografia: Perspectivas para o Cerrado no Século XXI, 2003, Uberlândia. Anais...Uberlândia: Universidade Federal de Uberlândia - UFU, 2003, p. 1-15.

MELLO-THERY, N. de; CORREIA, B. O. Pressão urbana em áreas de florestas: história e conflitos da proteção ambiental. Revista Mercator, v. 8, n. 16, p. 33-44, 2009.

MENDONÇA, R. Educação ambiental vivencial. In: FERRARO-JUNIOR, L. A. Encontros e caminhos: formação de educadoras (es) ambientais e coletivos educadores. Brasília: MMA, p. 117-130, 2007.

MENEZES, P. da. C. Raising the priority of urban areas in protected areas systems in Brazil and beyond. In: TRZYNA, T. The Urban Imperative. Sacramento, California: California Institute of Public Affairs, 2005, p. 5157.

MENEZES, P. C.; MENDES, L. O. T. The mission of protected areas in Brazil. In: MCNEELY, J. A. Cities and protected areas: an oxymoron or a partnership? Parks, v. 11, n. 3, p.52, 2001.

MICHEL, M. H. Metodologia e pesquisa científica em ciências sociais. São Paulo: Atlas, 2005.

MELAZO, G. C.; COLASANTI, M. T. M. Parques urbanos: importantes espaços verdes na dinâmica ambiental das cidades. In: SIMPÓSIO REGIONAL DE GEOGRAFIA: PERSPECTIVAS PARA O CERRADO NO SÉCULO XXI, 2003, Uberlândia. Anais...Uberlândia: Universidade Federal de Uberlândia - UFU, 2003. p. 1-15.

MILANO, M.S. Mitos no manejo de Unidades de Conservação no Brasil, ou a verdadeira ameaça. In: II Congresso Brasileiro de Unidades de Conservação, 2000, Campo Grande. Anais...Campo Grande. 2000. p. 11-25.

MILLER, K.R. Evolução do conceito de áreas de proteção: oportunidades para o século XXI. In: CONGRESSO BRASILEIRO DE UNIDADES DE CONSERVAÇÃO, 1997, Curitiba. Anais... Curitiba: IAP/ Universidade Livre do Meio Ambiente; Rede Pró Unidades de Conservação, 1997. p. 3-21. 
MINISTÉRIO DO MEIO AMBIENTE (MMA). O desafio de garantir participação no complexo universo da gestão. Brasília, 2015a.

$2015 b$.

Disponível em: <www.mma.gov.br/areas-protegidas/plano-de-areas-protegidas>. Acesso em: 20 mai.

MONTGOMERY, M. R.; STREN, R.; COHEN, B.; REED, H. E. (eds.). Cities transformed: demographic change and its implications in the developing world. London: National Academies Press, 2004.

MORGENROTH, J.; ÖSTBERG, J.; BOSCH, C. K.; NIELSEN, A. B.; HAUER, R.; SJÖMAN, H.; CHEN, W.; JANSSON, M. Urban tree diversity: taking stock and looking ahead. Urban Forestry \& Urban Greening, v. 15, p. 1-5, 2016.

MORSELLO, C. Áreas protegidas públicas e privadas: seleção e manejo. São Paulo: Annablume, FAPESP, 2006.

NAVARA, K. J.; R. J. NELSON. The dark side of light at night: physiological, epidemiological, and ecological consequences. Journal of Pineal Research, v.43, p.215-224, 2007.

NCHOR, A. A.; UGOGO, A. U. Rapid Assessment of Protected Area Pressure and Threats in Nigeria National Parks". Global Journal of Agricultural Sciences, v. 11 n.2, p. 63-72, 2012.

NOWAK, D. J.; WALTON, J. T. Projected urban growth (2000-2050) and its estimated impact on the US forest resource. Journal of Forestry, v. 103, n. 8, p. 383-389, 2005.

OLIVA, A. \& MAGRO, T. C. A Evolução do Planejamento do Entorno das Unidades de Conservação de Proteção Integral. In: IV Congresso Brasileiro de Unidades de Conservação. Anais... Curitiba: Fundação O Boticário de Proteção à Natureza: Rede Nacional Pró Unidades de Conservação, 2004. v. 1, p. 462-473.

OLIVEIRA, R. R. de; ZAÚ, A. S. Impactos da instalação de linhas de transmissão sobre ecossistemas florestais. Floresta e Ambiente, v. 5, n. 1, p. 184-191, 1998.

OLIVEIRA, J. A. P. de.; BALABAN, O.; DOLL, C. N. H.; MORENO-PEÑARANDA, R.; GASPARATOS, A.; IOSSIFOVA, D.; SUWA, A. Cities and biodiversity: Perspectives and governance challenges for implementing the convention on biological diversity (CBD) at the city level. Biological Conservation, v.144, p.1302-1313, 2011.

OXFORD DICTIONARY. Desenvolvido por Oxford University Press. Disponível em: <https://en.oxforddictionaries.com/definition/effectiveness>. Acesso em: out 2016.

PELlin, A.; CARVAlHO, G.; REIS, J.C.; PELliN, A. Gestão do Uso Público em Unidades de Conservação Urbanas: o Caso do Parque Estadual da Pedra Branca (RJ). Revista Brasileira de Ecoturismo, São Paulo, v.7, n.2, p.344-373, 2014.

PEREIRA, P. F.; SCARDUA, F. P. Espaços territoriais especialmente protegidos: conceito e implicações jurídicas. Ambiente \& Sociedade, v. 11, n. 1, p. 81-97, 2008.

PREFEITURA MUNICIPAL DE RIBEIRÃO PRETO. Desenvolvido por Coderp (Cia. de Desenvolvimento Econômico de Ribeirão Preto) e Coordenadoria de Comunicação Social. Disponível em: <http://www.ribeiraopreto.sp.gov.br/principal.php>. Acesso em: Ago 2016

PITT, B; BOULLE, T. Growing together: thinking and practice of urban nature conservators. Cape Town: SANBI Cape Flats Nature, 2010.

PUREZA, F., PELliN, A., PADUA, C. Unidades de Conservação. São Paulo: Matrix, 2015.

RAMOS, A. B. B. Contribuição para a gestão de Unidades de Conservação Urbanas: caso do Parque Estadual Dois Irmãos, PE. 2007. 212 p. Dissertação (Mestrado em Gestão e Políticas Ambientais). Universidade Federal de Pernambuco. Recife, 2007.

REDFORD, K. H. The empty forest. BioScience, v.42, n.6, p. 412-422, 1992. 
RESOLUÇÃO CONABIO n5 de 21 de outubro de 2009. Dispõe sobre a Estratégia Nacional sobre Espécies Exóticas Invasoras. Ministério do Meio Ambiente e Secretaria de Biodiversidade e Florestas: Comisão Nacional De Biodiversidade. 2009.

RIDDELL, L. Great Smoky Mountains National Park named among most endangered: Groups Say Air Pollutions Threatens More than 30 Species of Plant Life. Chattanooga Times Free Press, 2002.

ROCHA, L. G. M. da; DRUMMOND, J. A.; GANEM, R. S. Parques nacionais Brasileiros: problemas fundiários e alternativas para a sua resolução. Revista de Sociologia e Política, v. 18, n. 36, p.205-226, 2010.

RODRIGUES, C. G. de O. O uso público nos parques nacionais: a relação entre as esferas pública e privada na apropriação da biodiversidade. 2009. 358 p. Tese (Doutorado em Desenvolvimento Sustentável). Universidade de Brasília, Brasília. 2009.

ROWCLIFFE, J. M.; COWLISHAW, G.; LONG, J. A model of human hunting impacts in multi-prey communities. Journal of Applied Ecology, v.40, n.5, p.872-889, 2003.

RUNTE, A. National Parks: the American experience. Lincoln and London: University of Nebraska Press, 1979.

RYLANDS, A.B.; BRANDON, K. Unidades de conservação brasileiras. Megadiversidade, v.1, n.1, p.27-35, 2005.

SALAFSKY, N.; SALZER D.; STATTERSFIELD A. J.; HILTON-TAYLOR C.; NEUGARTEN R.; BUTCHART S. M.; COLLEN B.; COX N.; MASTER L. L.; O’CONNOR S.; WILKIE D. A standard lexicon for biodiversity conservation: unified classifications of threats and actions. Conservation Biology, v. 22, n. 4, p. 897911, 2008.

SÃO PAULO. Manual: Plano de Monitoramento e Gestão dos Impactos da Visitação. Desenvolvido pela Secretaria do Meio Ambiente (SMA) e Fundação Florestal. 2009.

SAUNDERS, D. A.; HOBBS, R. J.; MARGULES, C. R. Biological consequences of ecosystem fragmentation: a review. Conservation Biology, v. 5, p. 18-32. 1991.

SCHIAVETTI, A.; MAGRO, T. C.; SANTOS, M. S. Implementação das unidades de conservação do corredor central da Mata Atlântica no estado da Bahia: desafios e limites. Revista Árvore, v. 36, n. 4, p. 611-623, 2012.

SECRETARIADO DA CONVENÇÃO SOBRE DIVERSIDADE BIOLÓGICA. Panorama da biodiversidade nas cidades: avaliação global entre as conexões da urbanização, biodiversidade e os serviços ecossistêmicos. Montreal, 2012.

SILVA, J. A. Aplicabilidade das normas constitucionais. São Paulo: Revista dos Tribunais, 2000.

SILVA, J. C. Diagnóstico das áreas de maior incidência de incêndios florestais em Unidades de Conservação Pertencentes a APA Gama - Cabeça de Veado. 2001. Dissertação (Mestrado em Ciências Florestais). Universidade de Brasília, Brasília, 2001.

SISTEMA AMBIENTAL PAULISTA. Desenvolvido pelo Governo do Estado de São Paulo. Disponível em <http://www.ambiente.sp.gov.br/>. Acesso em: Abr 2017.

SOARES, R.V.; BATISTA, A.C. Incêndios florestais: controle, efeitos e uso do fogo. UFPR. 264p. 2007.

SOUZA, P. C. A. Funções sociais e ambientais de parque urbano instituído como Unidade de Conservação: percepção dos usuários do Parque Natural Municipal do Barigui, Curitiba, Paraná. Dissertação (Mestrado). Pontifícia Universidade Católica do Paraná. Curitiba, 2010.

SOUZA, E. R. de; LIMA, M. L. C. de. Panorama da violência urbana no Brasil e suas capitais. Ciência \& Saúde Coletiva, v. 11, p.1211-1222, 2006. 
SOUZA, J. L. de; VIEIRA, C. L.; SILVA, D. C. B. de. Roteiro Metodológico para Elaboração de Plano de Manejo para Reservas Particulares do Patrimônio Natural (RPPN). Ministério do Meio Ambiente: Brasília, 2015.

SPOELDER, P.; LOCKWOOD, M.; COWELL, S.; GREGERSON, P.; HENCHMAN, A. Planning. In: WORBOYS, G. L.; LOCKWOOD, M.; KOTHARI, A.; FEARY, S. PULSFORD, I. (eds). Protected Area Governance and Management. Canberra: ANU Press, 2015, p.381-412.

STEFFEN, W.; SANDERSON, A.; TYSON, P.D.; JAGER, J.; MATSON, P.A.; MOORE III, B.; OLDFIELD, F.; RICHARDSON, K.; SCHELLNHUBER, H.J.; TURNER II B.L.; WASSON, R.J. Global Change and the Earth System: A Planet Under Pressure. Berlin, Germany: Springer, 2004.

STEFFEN, W.; RICHARDSON, K.; ROCKSTRÖM, J.; CORNELL, S. E.; FETZER, I.; BENNETT, E. M.; FOLKE, C. Planetary boundaries: Guiding human development on a changing planet. Science, v. 347, n. 6223, p. $1259855,2015$.

STOLTON, S.; DUDLEY, N. Arguments for Protected Areas: Multiple Benefits for Conservation and Use. Earthscan, 2010.

STOLTON, S.; DUDLEY, N.; ÇOKÇALIŞKAN, A. B.; HUNTER, D.; IVANIĆ, K. Z.; KANGA, E.; KETTUNEN, M.; KUMAGAI, Y.; MAXTED, N.; SENIOR, J.; WONG, M.; KEENLEYSIDE, K.; MULROONEY, D.; WAITHAKA, J. Values and benefits of protected areas. In: WORBOYS, G. L.; LOCKWOOD, M.; KOTHARI, A.; FEARY, S. PULSFORD, I. (eds). Protected Area Governance and Management. Canberra: ANU Press, 2015, p. 145-168.

SUNDSETH, K.; RAEYMAEKERS, G. Biodiversity and Natura 2000 in urban areas: a review of issues and experiences of nature in cities across Europe for the Brussels Capital Region. Bruxelles Environnement - IBGE /Leemilieu Brussel - BIM: Brussels, 2006.

TERBORGH, J.; VAN SCHAIK C.; DAVENPORT, L.; RAO, M. Tornando os parques eficientes: estratégias para a conservação da natureza nos trópicos. Curitiba: Editora da Universidade Federal do Paraná; Fundação O Boticário de Proteção à Natureza, 2002. p. 52-73.

THOMAS, L.; MIDDLETON, J. Guidelines for Management Planning of Protected Areas. IUCN Gland, Switzerland and Cambridge, UK. 2003. 79p.

TROCMÉ, M. Habitat Fragmentation due to Linear Transportation Infrastructure: An overview of mitigation measures in Switzerland. In: Proceedings of the 6th Swiss Transport Research Conference. Monte Verita/Ascona, Switzerland, 2006. p. 1-20.

TRZYNA, T. The Urban Imperative. California Institute of Public Affairs, Sacramento, California, 2005. 168p.

Global Urbanization and Protected Areas. Sacramento, California: California Institute of Public Affairs, 2007.

. Urban Protected Areas: Profiles and best practice guidelines. Best Practice Protected Area Guidelines Series, n. 22, Gland, Switzerland: IUCN, 2014.

UNITED NATIONS POPULATION DIVISION (UNPD). World urbanization prospects 2011. New York: UNPD, 2011.

World Urbanization Prospects: The 2014 Revision. New York: UNPD, 2015.

VARANDA, E. M.; LAPENTA, M. J.; GIMENEZ, V. M. M.; VASTERS, M. P.; SANTOS, H. F. dos; BAROSELA, J. R.; DONADIO, N. M. M.; GAIOSO-RAFAEL, L. M.; OLIVEIRA, C. de. Áreas Prioritárias ao Restabelecimento da Conectividade Estrutural entre Fragmentos Florestais da Zona de Amortecimento da Estação Ecológica de Ribeirão Preto. Revista do Instituto Florestal, v. 27, n.1, p. 49-71 jun. 2015. 
VOIGT, A.; WURSTER, D. Does diversity matter? The experience of urban nature's diversity: Case study and cultural concept. Ecosystem Services, v. 12, p. 200-208, 2015.

VROMANS, D.C.; MAREE, K.S.; HOLNESS, S.; JOB, N.; BROWN, A.E. The Garden Route Biodiversity Sector Plan for the George, Knysna and Bitou Municipalities. Supporting land-use planning and decisionmaking in Critical Biodiversity Areas and Ecological Support Areas for sustainable development. Garden Route Initiative. South African National Parks. Knysna, 2010.

WATSON, J. E.; DUDLEY, N.; SEGAN, D. B.; HOCKINGS, M. The performance and potential of protected areas. Nature, v. 515, n. 7525, p. 67-73, 2014.

WILCOVE, D.S.; ROTHSTEIN, D.; DUBOW, J.; PHILLIPS, A.; LOSOS, E. Quantifying threats to imperiled species in the United States. BioScience, v. 48, p. 607-615, 1998.

WORBOYS, G. L. Concept, purpose and challenges. In: WORBOYS, G. L.; LOCKWOOD, M.; KOTHARI, A.; FEARY, S. PULSFORD, I. (eds). Protected Area Governance and Management. Canberra: ANU Press, 2015, p.9-42.

WORBOYS, G. L.; LOCKWOOD, M.; KOTHARI, A.; FEARY, S.; PULSFORD, I. Protected Area Governance and Management. ANU Press, Canberra, 2015. 994p.

WORBOYS, G. L.; TRZYNA, T. Managing protected areas. In: WORBOYS, G. L.; LOCKWOOD, M.; KOTHARI, A.; FEARY, S. PULSFORD, I. (eds). Protected Area Governance and Management. Canberra: ANU Press, 2015, p. 207-250.

WORBOYS, G. L.; WINKLER, C.; LOCKWOOD, M. Threats to protected areas. In: LOCKWOOD, M.; WORBOYS, G. L.; KOTHARI, A. (eds). Protected Area Management: A global guide. Earthscan, London. 2006. 802 p.

WU, J. Urban ecology and sustainability: The state-of-the-science and future directions. Landscape and Urban Planning, v. 125, p. 209-221, 2014.

ZHANG, X. Q. The trends, promises and challenges of urbanisation in the world. Habitat International, v.54, p. 241-252, 2016. 


\section{APÊNDICES}

Apêndice I. Questionário online para coleta de informações sobre unidades de conservação (UCs) do Estado De São Paulo.

Categoria e Nome da Unidade:

Nome do Gestor(a):

Área da Unidade (ha):

Marcar com um "X" a resposta apropriada:

1) Apresenta plano de manejo?

( ) $\mathrm{Sim}$

( ) Não

( ) Em elaboração:

2) Situação fundiária:

( ) Regularizada

( ) Não regularizada

( ) Em regularização:

\section{3) Infraestrutura geral da unidade}

(Exemplo: no caso das Estações Ecológicas e Reservas Biológicas: presença de alojamento para pesquisador, laboratório, centro de vivência e sede administrativa - no caso de parques: centro de visitantes, trilhas, placas e sede administrativa).

( ) Completa, de acordo com a categoria da unidade

( ) Parcialmente completa, de acordo com a categoria da unidade

( ) Incompleta, de acordo com a categoria da unidade

( ) sem nenhuma infraestrutura

( ) dados inexistentes

4) Infraestrutura em relação ao número de funcionários (Instituição e outros):

( ) Suficiente

( ) Insuficiente

( ) dados inexistentes

5) Em relação à questão anterior, qual o número atual de funcionários? (Cálculo aproximado)

6) Qual seria o número ideal de funcionários para a Unidade? (Cálculo aproximado)

7) Infraestrutura em relação aos equipamentos e materiais (transporte, comunicação interna e externa, equipamento de escritório, equipamento para fiscalização, material de consumo):

( ) Completa (todos os equipamentos e materiais necessários para o funcionamento da unidade)

( ) Parcialmente completa (possui parte dos equipamentos e/ou materiais necessários para o funcionamento da unidade)

( ) Incompleta (nenhum equipamento e material)

( ) dados inexistentes

8) Forma predominante de uso do solo no entorno da unidade (marcar mais de uma opção quando houver):

( ) Área natural

( ) Agricultura

( ) Pecuária

( ) Exploração madeireira

( ) Polo industrial

( ) Área urbana 
( ) Mineração
( ) dados inexistentes
( ) Outros (Identifique):

9) Apresenta algum tipo de pressão (marcar mais de uma opção quando houver):

( ) Pressão externa pelo crescimento urbano acelerado

( ) Pressão externa pela especulação imobiliária

( ) Pressão externa pelas atividades agropecuárias no entorno

( ) Definições inadequadas de limites e categorias

( ) Tráfico de animais na unidade

( ) Queimadas predatórias

( ) Ocupação irregular (dentro e/ou fora da unidade)

( ) Deficiência na fiscalização

( ) Outros (Identifique):

10) Existem procedimentos adotados para a resolução ou mitigação das pressões citadas no item anterior? ( ) Não.

( ) $\mathrm{Sim}$

11) Caso a resposta anterior tenha sido "SIM", explicar de maneira objetiva o que são esses procedimentos e como eles vêm sendo aplicados em sua Unidade. Caso a resposta tenha sido "NÃO", explicar o motivo da não adoção de medidas mitigatórias:

(a presente resposta é muito importante para o atual estudo. Sendo assim, por favor nos informe, de maneira bem sucinta, sobre como os conflitos em sua Unidade vêm sendo solucionados e se houve resultados positivos ou negativos). 
Apêndice II. Roteiro dirigido para entrevistas com gestores de UCs do Estado de São Paulo

Pesquisa: Análise das ações mitigatórias de pressões e ameaças urbanas em unidades de conservação nacionais e internacionais

Projeto FAPESP: ${ }^{\circ} 2014 / 15086-0$

Pesquisadora: Rafaela Aguilar Sansão (EACH - Universidade de São Paulo)

Supervisor: Prof. Dr. Marcelo Pereira de Souza (FFCLRP - Universidade de São Paulo)

Adaptado da Metodologia RAPPAM (Rapid Assessment and Prioritization of Protected Area Management) e dividido em três seções (A, B, C).

SEÇÃO A: fornece uma visão geral sobre o contexto da UC, a fim de se obter um melhor entendimento sobre sua importância biológica, econômica, e social. Essa seção é dividida em 4 tópicos: perfil, contexto, planejamento e recursos humanos (insumos).

\section{PERFIL:}

a) Nome da UC:

b) Data de criação:

c) Área (em hectares):

d) Nome do gestor:

e) Data de preenchimento:

Preencher os seguintes tópicos de acordo com a sua opinião:

D/T- Discordo totalmente D- Discordo parcialmente I- Indiferente (sem opinião) C-Concordo parcialmente C/T Concordo totalmente

\section{CONTEXTO}

\begin{tabular}{|c|c|c|c|c|c|}
\hline 2. IMPORTÂNCIA BIOLÓGICA & $\mathbf{D} / \mathbf{T}$ & $\mathbf{D}$ & I & $\mathbf{C}$ & $\mathrm{C} / \mathrm{T}$ \\
\hline a) A UC possui um nível relativamente alto de endemismo. & & & & & \\
\hline b) A UC possui níveis relativamente altos de biodiversidade. & & & & & \\
\hline c) A UC contém um número relativamente alto de espécies raras, ameaçadas ou sob ameaça. & & & & & \\
\hline d) A UC exerce uma função crítica de paisagem. & & & & & \\
\hline e) A UC conserva uma diversidade completa de processos naturais e de regimes de distúrbio. & & & & & \\
\hline
\end{tabular}

\begin{tabular}{|c|c|c|c|c|c|}
\hline 3. IMPORTÂNCIA SOCIO-ECONÔMICA & $\mathbf{D} / \mathbf{T}$ & D & $\mathbf{I}$ & C & $\mathrm{C} / \mathrm{T}$ \\
\hline $\begin{array}{l}\text { a) A UC contém espécies de plantas e animais de alta } \\
\text { econômica. Se sim, quais são as principais? }\end{array}$ & & & & & \\
\hline b) As comunidades locais dependem de recursos da U & & & & & \\
\hline c) A UC contribui com serviços e benefícios significa & & & & & \\
\hline d) A UC possui alto valor recreativo. & & & & & \\
\hline e) A UC possui alto valor educacional e/ou científico. & & & & & \\
\hline
\end{tabular}

\begin{tabular}{|c|c|c|c|c|c|}
\hline 4. VULNERABILIDADE & $\mathbf{D} / \mathbf{T}$ & $\mathbf{D}$ & I & $\mathbf{C}$ & $\mathrm{C} / \mathrm{T}$ \\
\hline a) Existem atividades ilegais dentro da UC. Se sim, quais? & & & & & \\
\hline b) Atividades ilegais na UC são difíceis para monitorar. & & & & & \\
\hline c) Existem impactos oriundos das atividades ilegais. & & & & & \\
\hline d) Existe uma grande demanda por recursos vulneráveis da UC. & & & & & \\
\hline
\end{tabular}




\section{PLANEJAMENTO}

\begin{tabular}{|c|c|c|c|c|c|}
\hline 5. OBJETIVOS & $\mathbf{D} / \mathbf{T}$ & D & I & $\mathbf{C}$ & $\mathbf{C} / \mathbf{T}$ \\
\hline a) As comunidades locais apoiam os objetivos globais da UC. & & & & & \\
\hline b) Os funcionários e os administradores da UC entendem os objetivos e as políticas da UC. & & & & & \\
\hline c) Existe um plano de manejo escrito. Se sim, quando foi feito? & & & & & \\
\hline $\begin{array}{l}\text { d) O plano de manejo é adequado. Se não, por que? Quais são os principais problemas com } \\
\text { ele? }\end{array}$ & & & & & \\
\hline
\end{tabular}

\begin{tabular}{|c|c|c|c|c|c|}
\hline 6. AMPARO LEGAL & $\mathbf{D} / \mathbf{T}$ & $\mathbf{D}$ & $\mathbf{I}$ & $\mathbf{C}$ & $\mathbf{C} / \mathbf{T}$ \\
\hline a) A demarcação de fronteiras é adequada para alcançar os & & & & & \\
\hline b) A situação fundiária da UC está regularizada. & & & & & \\
\hline $\begin{array}{l}\text { c) Se sim, quantos \% regularizada? } \\
\begin{array}{llll}\text { ( ) } 90-100 \% & \text { ( ) } 70-89 \% & \text { ( ) } 50-69 \% & \text { ( ) } 30-49 \% \\
\text { ( ) dados inexistentes } & 0-29 \%\end{array}\end{array}$ & & & & & \\
\hline
\end{tabular}

\begin{tabular}{|c|c|c|c|c|c|}
\hline 7. DESENHO E PLANEJAMENTO DA ÁREA & $\mathrm{D} / \mathrm{T}$ & $\mathbf{D}$ & I & $\mathbf{C}$ & $\mathbf{C} / \mathbf{T}$ \\
\hline a) A localização da UC é coerente com os objetivos da UC. & & & & & \\
\hline b) O sistema de zoneamento da UC é adequado para alcanças os objet & & & & & \\
\hline c) O uso da terra no entorno propicia o manejo efetivo da UC. & & & & & \\
\hline d) A UC é ligada à outra UC ou a outra área protegida. Se sim, qual? & & & & & \\
\hline
\end{tabular}

\section{RECURSOS HUMANOS - INSUMOS}

\begin{tabular}{|c|c|c|c|c|c|}
\hline 8. RECURSOS HUMANOS & $\mathbf{D} / \mathbf{T}$ & D & I & $\mathbf{C}$ & $\mathbf{C} / \mathbf{T}$ \\
\hline \multicolumn{6}{|c|}{ a) O nível de recursos humanos é suficiente para o manejo efetivo da UC. } \\
\hline \multicolumn{6}{|c|}{$\begin{array}{l}\text { b) Os funcionários devem possuir as habilidades adequadas para realizar as ações de manejo } \\
\text { críticas. }\end{array}$} \\
\hline \multicolumn{6}{|c|}{$\begin{array}{l}\text { c) Existem oportunidades de capacitação e desenvolvimento apropriadas às necessidades dos } \\
\text { funcionários. }\end{array}$} \\
\hline \multicolumn{6}{|c|}{ d) A UC possui um conselho. Se sim, é composto por quem? } \\
\hline e) Qual é a educação professional do gestor responsável pela UC? & & & & & \\
\hline
\end{tabular}

\begin{tabular}{|c|c|c|c|c|c|}
\hline 9. COMUNICAÇÃO E INFORMAÇÃO & $\mathbf{D} / \mathbf{T}$ & $\mathbf{D}$ & I & $\mathbf{C}$ & $\mathbf{C} / \mathbf{T}$ \\
\hline $\begin{array}{l}\text { a) Os dados ecológicos e socioeconômicos existentes são ad } \\
\text { manejo. }\end{array}$ & & & & & \\
\hline b) Existe comunicação efetiva entre as comunidades locais. & & & & & \\
\hline
\end{tabular}

\begin{tabular}{|c|c|c|c|c|c|}
\hline 10. INFRA-ESTRUTURA & $\mathbf{D} / \mathbf{T}$ & D & $\mathbf{I}$ & $\mathbf{C}$ & $\mathrm{C} / \mathrm{T}$ \\
\hline $\begin{array}{l}\text { a) A infra-estrutura de transporte é adequada para realizer as ações de manejo críticas. Se não, } \\
\text { por que? }\end{array}$ & & & & & \\
\hline $\begin{array}{l}\text { b) O equipamento de campo é adequado para a realização de ações de manejo críticas. Se não, } \\
\text { por que? }\end{array}$ & & & & & \\
\hline $\begin{array}{l}\text { c) A infra-estrutura para os funcionários é adequada para a realização de ações de manejo } \\
\text { críticas. Se não, por que? }\end{array}$ & & & & & \\
\hline $\begin{array}{l}\text { d) A infra-estrutura para visitantes é apropriada para o nível de uso pelo visitante. Se não, por } \\
\text { que? }\end{array}$ & & & & & \\
\hline
\end{tabular}




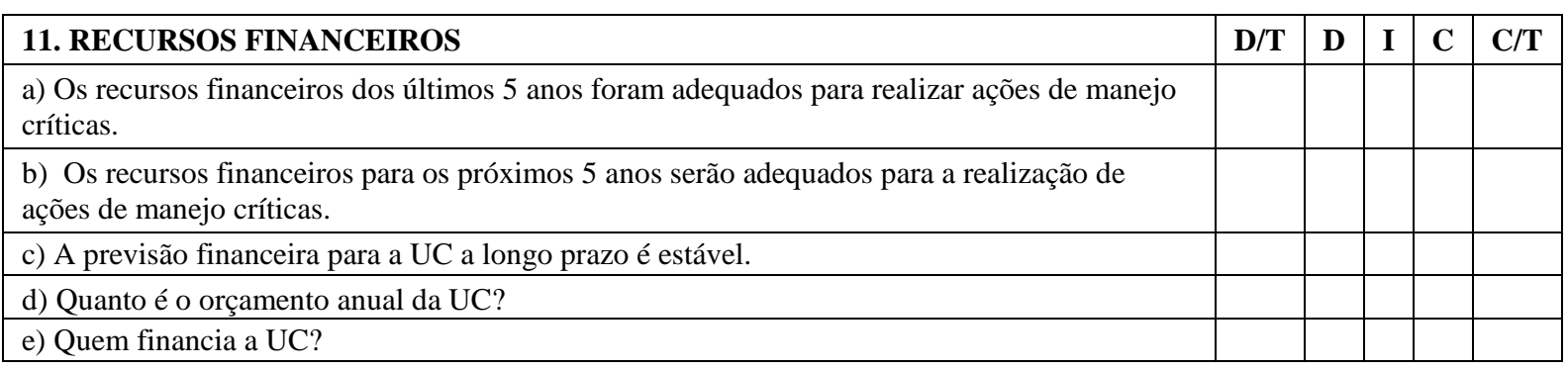

SECCÃO B: Lista de verificação (checklist) de pressões e ameaças urbanas comuns às UCs. O objetivo desta seção é compreender as principais atividades que podem estar trazer impactos prejudiciais para as unidades.

\section{Definições importantes:}

- PRESSÕES: são processos, ações ou eventos, que já tiveram um impacto prejudicial sobre a integridade da unidade de conservação (e.g. aqueles que resultaram em uma diminuição da diversidade ou capacidade biológica, e/ou um empobrecimento dos recursos naturais da unidade). As pressões abrangem as atividades legais e ilegais e podem resultar dos impactos diretos ou indiretos de tais forças.

- AMEAÇAS: são processos, atividades ou eventos potenciais pelos quais um impacto prejudicial provavelmente ocorrerá ou continuará no futuro.

\section{1) Selecione as pressões (P) e ameaças (A) presentes na UC:}

\begin{tabular}{|c|c|c|}
\hline \multirow{2}{*}{ 1) Desenvolvimento urbano do entorno } & $\mathbf{P}$ & $\mathbf{A}$ \\
\hline & & \\
\hline 2) Estradas, ferrovias e/ou portos & & \\
\hline 3) Linhas de transmissão de energia & & \\
\hline 4) Atividades industriais & & \\
\hline $\begin{array}{l}\text { 5) Mineração (incluindo todas as formas de escavação, mineração e exploração de recursos subterrâneos, } e \\
\text { também os resíduos produzidos por tais atividades) }\end{array}$ & & \\
\hline 6) Ocupações ilegais & & \\
\hline 7) Turismo e recreação & & \\
\hline 8) Disposição de resíduos (e.g. embalagens de alimentos de turistas e entulho) & & \\
\hline $\begin{array}{l}\text { 9) Espécies exóticas invasoras (plantas e os animais introduzidos intencionalmente ou inadvertidamente por } \\
\text { humanos) }\end{array}$ & & \\
\hline 10) Extrativismo de madeira & & \\
\hline $\begin{array}{l}\text { 11) Extração de recursos (inclui a coleta de produtos florestais não-madeireiros, como alimentos, plantas } \\
\text { medicinais, material de construção, resinas e outros recursos da área protegida, seja para comércio ou para } \\
\text { subsistência) }\end{array}$ & & \\
\hline 12) Caça ilegal & & \\
\hline 13) Pesca ilegal & & \\
\hline 14) Conflitos entre humanos e animais selvagens & & \\
\hline 15) Poluição atmosférica & & \\
\hline 16) Poluição sonora (e.g sobrevôos de aeronaves, tráfego de carros, ruídos de construções) & & \\
\hline 17) Poluição visual (e.g luzes noturnas) & & \\
\hline 18) Poluição dos recursos hídricos & & \\
\hline 19) Construção de barragens (para recreio, pesca, água potável e geração de energia) & & \\
\hline 20) Disputas sobre uso da água (para o uso da população) & & \\
\hline 21) Desvio de córregos e rios & & \\
\hline 22) Eventos catastróficos semi-naturais (ampliados pela intervenção humana - e.g incêndios e inundações) & & \\
\hline 23) Mudanças climáticas & & \\
\hline 24) Crimes (e.g contrabando, uso de drogas, etc). & & \\
\hline 25) Outros & & \\
\hline
\end{tabular}




\section{2) Preencha os quadros para as pressões e ameaças assinaladas:}

\section{PRESSÃO:}

\begin{tabular}{|l|lll|}
\hline Nos últimos 5 anos a atividade: & \multicolumn{3}{|c|}{ O nível de pressão nos últimos 5 anos tem sido: } \\
\hline ( ) Aumentou drasticamente & \multicolumn{1}{|c|}{ Abrangência } & \multicolumn{1}{c|}{ Impacto } & \multicolumn{1}{c|}{ Permanência } \\
( ) Aumentou ligeiramente & ( ) Total $(>50 \%)$ & ( ) Severo & ( ) Permanente (>100 anos) \\
( ) Permaneceu constante & ( ) Generalizada $(15-50 \%)$ & ( ) Alto & ( ) A longo prazo (20-100 anos) \\
( ) Diminuiu ligeiramente & ( ) Espalhada $(5-15 \%)$ & ( ) Moderado & ( ) A médio prazo (5-20 anos) \\
( ) Diminuiu drasticamente & ( ) Localizada (<5\%) & ( ) Suave & ( ) A curto prazo (<5 anos) \\
\hline
\end{tabular}

\section{AMEAÇA:}

\begin{tabular}{|c|c|c|c|}
\hline $\begin{array}{c}\text { A probabilidade dessa ameaça } \\
\text { se concretizar é: }\end{array}$ & \multicolumn{3}{|c|}{ A severidade desta ameaça nos próximos 5 anos será provavelmente: } \\
\hline ( ) Muito alta & Abrangência & Impacto & Permanência \\
\hline ( ) Alta & ( ) Total $(>50 \%)$ & ( ) Severo & ( ) Permanente (>100 anos) \\
\hline ( ) Média & ( ) Generalizada (15-50\%) & ( ) Alto & ( ) A longo prazo (20-100 anos) \\
\hline ( ) Baixa & ( ) Espalhada (5-15\%) & ( ) Moderado & ( ) A médio prazo (5-20 anos) \\
\hline ( ) Muito baixa & ( ) Localizada (<5\%) & ( ) Suave & ( ) A curto prazo (<5 anos) \\
\hline
\end{tabular}

SEÇ̃̃O C: Seção livre para discussão sobre as ações mitigatórias que são adotadas para as pressões e ameaças identificadas na seção B.

1) Quais são os principais impactos resultantes das pressões identificadas?

2) Existe alguma ação de conservação voltada para a mitigação dessas pressões?

3) Como elas vêm sendo implementadas? Como funcionam na prática?

4) Caso não haja, por que nada tem sido feito?

5) As ações estão presentes nos planos de manejo?

6) As partes interessadas estão envolvidos no processo de implementação desta ação? De que maneira?

7) Qual o tempo médio para implementar as ações?

8) Os funcionários são treinados para executá-las?

9) Quais são os fatores que levaram ao sucesso ou não da implementação dessas ações? 
Apêndice III. Matriz síntese da avaliação das pressões e ameaças do Parque Estadual do Jaraguá (PEJ).

\begin{tabular}{|c|c|c|c|c|c|c|c|c|c|c|c|}
\hline PRESSÕES ${ }^{\mathrm{a}}$ & $\mathbf{A}^{\mathrm{b}}$ & $\mathbf{I}^{\mathrm{c}}$ & $\mathbf{P}^{\mathrm{d}}$ & PONTUAÇÃO ${ }^{\mathrm{e}}$ & INTENSIDADE $^{\mathrm{f}}$ & AMEAÇAS ${ }^{g}$ & $\mathbf{A}$ & I & $\mathbf{P}$ & PONTUAÇÃO & INTENSIDADE \\
\hline Desenvolvimento urbano & 3 & 4 & 3 & 36 & \multirow{4}{*}{ SEVERO } & Mudanças climáticas & 4 & 4 & 4 & 64 & \multirow{4}{*}{ SEVERO } \\
\hline Mudanças climáticas & 3 & 3 & 4 & 36 & & Desenvolvimento urbano & 4 & 4 & 3 & 48 & \\
\hline Poluição atmosférica & 3 & 4 & 3 & 36 & & Poluição atmosférica & 4 & 4 & 3 & 48 & \\
\hline Estradas e rodovias & 3 & 3 & 3 & 27 & & Estradas e rodovias & 3 & 4 & 3 & 36 & \\
\hline Poluição hídrica & 2 & 4 & 3 & 24 & \multirow{4}{*}{ ALTO } & Atividades industriais & 2 & 3 & 3 & 18 & \multirow{10}{*}{ ALTO } \\
\hline Atividades religiosas & 2 & 3 & 3 & 18 & & Disposição de resíduos & 2 & 3 & 3 & 18 & \\
\hline Extração de produtos não-madeireiros & 1 & 4 & 3 & 12 & & Incêndios & 2 & 3 & 3 & 18 & \\
\hline Ocupações ilegais & 2 & 3 & 2 & 12 & & Linhas de transmissão de energia & 2 & 3 & 3 & 18 & \\
\hline Atividades industriais & 1 & 3 & 3 & 9 & \multirow{10}{*}{ MODERADO } & Atividades religiosas & 2 & 3 & 2 & 12 & \\
\hline Disposição de resíduos & 1 & 3 & 3 & 9 & & $\begin{array}{l}\text { Conflitos entre humanos e animais } \\
\text { selvagens }\end{array}$ & 2 & 3 & 2 & 12 & \\
\hline Incêndios & 1 & 3 & 3 & 9 & & Disputas sobre o uso d'água & 2 & 3 & 2 & 12 & \\
\hline Linhas de transmissão de energia & 1 & 3 & 3 & 9 & & Espécies exóticas invasoras & 2 & 3 & 2 & 12 & \\
\hline Poluição sonora & 3 & 3 & 1 & 9 & & Poluição sonora & 3 & 4 & 1 & 12 & \\
\hline Disputas sobre o uso d'água & 2 & 2 & 2 & 8 & & Poluição visual & 3 & 2 & 2 & 12 & \\
\hline Espécies exóticas invasoras & 2 & 2 & 2 & 8 & & Extração de produtos não-madeireiros & 1 & 3 & 3 & 9 & \multirow{4}{*}{ MODERADO } \\
\hline Poluição visual & 2 & 2 & 2 & 8 & & Poluição hídrica & 1 & 3 & 3 & 9 & \\
\hline Caça ilegal & 1 & 3 & 2 & 6 & & Ocupações ilegais & 1 & 3 & 2 & 6 & \\
\hline Conflitos entre humanos e animais selvagens & 1 & 3 & 2 & 6 & & Caça ilegal & 1 & 2 & 2 & 4 & \\
\hline Crimes & 1 & 1 & 1 & 1 & LEVE & Crimes & 1 & 2 & 1 & 2 & LEVE \\
\hline
\end{tabular}

${ }^{a}$ Pressões são processos, ações ou eventos, que já tiveram um impacto prejudicial sobre a integridade da UC (ERVIN, 2003).

${ }^{b}$ Abrangência: âmbito no qual o impacto de uma atividade ocorre, o qual pode ser medido em número, volume, área, etc. (ERVIN, 2003).

c Impacto: grau em que a pressão afeta direta ou indiretamente os recursos da unidade de conservação (ERVIN, 2003).

d Permanência: período de tempo necessário para os recursos da unidade de conservação se recuperarem das pressões, sem ou com a intervenção antrópica; resiliência (ERVIN, 2003).

e Pontuação é o produto da multiplicação dos três elementos (abrangência, impacto e permanência), que varia entre 1 e 64 (ERVIN, 2003).

${ }_{\mathrm{f}}^{\mathrm{f}}$ Intensidade são os valores das pressões e ameaças, os quais poderão variar entre 01 e 64 , sendo considerados leves se ficarem compreendidos entre 01 e 03 , moderados entre 04 e 09 , altos entre

10 e 24 e severos entre 25 e 64 (ERVIN, 2003).

g Ameaças são processos, atividades ou eventos potenciais pelos quais um impacto prejudicial provavelmente ocorrerá ou continuará no futuro (ERVIN, 2003). 
Apêndice IV. Matriz síntese da avaliação das pressões e ameaças do Parque Estadual da Cantareira (PEC).

\begin{tabular}{|c|c|c|c|c|c|c|c|c|c|c|c|}
\hline PRESSÕES ${ }^{\mathrm{a}}$ & $\mathbf{A}^{\mathrm{b}}$ & $\mathbf{I}^{\mathrm{c}}$ & $\mathbf{P}^{\mathrm{d}}$ & PONTUAÇÃ̃O & INTENSIDADE $^{\mathrm{f}}$ & AMEAÇAS $^{g}$ & $\mathbf{A}$ & I & $\mathbf{P}$ & PONTUAÇÃO & INTENSIDADE \\
\hline Desenvolvimento urbano do entorno & 3 & 4 & 3 & 36 & \multirow{6}{*}{ SEVERO } & Desenvolvimento urbano do entorno & 4 & 4 & 3 & 48 & \multirow{11}{*}{ SEVERO } \\
\hline Poluição atmosférica & 3 & 4 & 3 & 36 & & Poluição atmosférica & 4 & 4 & 3 & 48 & \\
\hline Espécies exóticas invasoras & 3 & 3 & 3 & 27 & & Estradas, rodovias e ferrovias & 3 & 4 & 3 & 36 & \\
\hline Estradas, rodovias e ferrovias & 3 & 3 & 3 & 27 & & Mudanças climáticas & 4 & 3 & 3 & 36 & \\
\hline Mudanças climáticas & 3 & 3 & 3 & 27 & & Ocupações ilegais & 3 & 4 & 3 & 36 & \\
\hline Ocupações ilegais & 3 & 3 & 3 & 27 & & Crimes & 3 & 3 & 3 & 27 & \\
\hline Caça ilegal & 2 & 3 & 3 & 18 & \multirow{10}{*}{ ALTO } & Disposição de resíduos & 3 & 3 & 3 & 27 & \\
\hline Crimes & 3 & 2 & 3 & 18 & & Espécies exóticas invasoras & 3 & 3 & 3 & 27 & \\
\hline Disposição de resíduos & 2 & 3 & 3 & 18 & & Incêndios & 3 & 3 & 3 & 27 & \\
\hline Incêndios & 2 & 3 & 3 & 18 & & Poluição dos recursos hídricos & 3 & 3 & 3 & 27 & \\
\hline Linhas de transmissão de energia & 2 & 3 & 3 & 18 & & Turismo e recreação & 3 & 3 & 3 & 27 & \\
\hline Poluição dos recursos hídricos & 2 & 3 & 3 & 18 & & Caça ilegal & 2 & 3 & 3 & 18 & \multirow{6}{*}{ ALTO } \\
\hline Turismo e recreação & 2 & 3 & 3 & 18 & & Conflitos entre humanos e animais selvagens & 3 & 3 & 2 & 18 & \\
\hline $\begin{array}{l}\text { Conflitos entre humanos e animais } \\
\text { selvagens }\end{array}$ & 2 & 3 & 2 & 12 & & Disputas sobre uso da água & 3 & 3 & 2 & 18 & \\
\hline Disputas sobre uso da água & 2 & 3 & 2 & 12 & & Linhas de transmissão de energia & 2 & 3 & 3 & 18 & \\
\hline Extração de recursos & 2 & 3 & 2 & 12 & & Extração de recursos & 2 & 3 & 2 & 12 & \\
\hline Atividades religiosas & 1 & 3 & 3 & 9 & \multirow{4}{*}{ MODERADO } & Poluição sonora & 3 & 4 & 1 & 12 & \\
\hline Mineração & 1 & 3 & 3 & 9 & & Atividades religiosas & 1 & 3 & 3 & 9 & \multirow{3}{*}{ MODERADO } \\
\hline Poluição sonora & 3 & 3 & 1 & 9 & & Mineração & 1 & 3 & 3 & 9 & \\
\hline Poluição visual & 3 & 2 & 1 & 6 & & Poluição visual & 3 & 3 & 1 & 9 & \\
\hline
\end{tabular}

a Pressões são processos, ações ou eventos, que já tiveram um impacto prejudicial sobre a integridade da UC (ERVIN, 2003).

${ }^{\mathrm{b}}$ Abrangência: âmbito no qual o impacto de uma atividade ocorre, o qual pode ser medido em número, volume, área, etc. (ERVIN, 2003).

c Impacto: grau em que a pressão afeta direta ou indiretamente os recursos da unidade de conservação (ERVIN, 2003).

d Permanência: período de tempo necessário para os recursos da unidade de conservação se recuperarem das pressões, sem ou com a intervenção antrópica; resiliência (ERVIN, 2003).

e Pontuação é o produto da multiplicação dos três elementos (abrangência, impacto e permanência), que varia entre 1 e 64 (ERVIN, 2003 ).

${ }_{\mathrm{f}}^{\mathrm{f}}$ Intensidade são os valores das pressões e ameaças, os quais poderão variar entre 01 e 64 , sendo considerados leves se ficarem compreendidos entre 01 e 03 , moderados entre 04 e 09 , altos entre

10 e 24 e severos entre 25 e 64 (ERVIN, 2003).

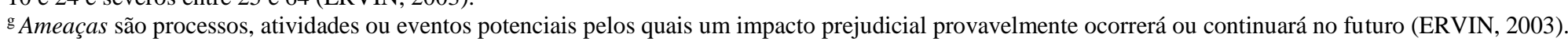


Apêndice V. Matriz síntese da avaliação das pressões e ameaças da Estação Ecológica de Ribeirão Preto (EERP).

\begin{tabular}{|c|c|c|c|c|c|}
\hline PRESSÕES ${ }^{\mathrm{a}}$ & $\mathbf{A}^{\mathrm{b}}$ & $\mathbf{I}^{\mathrm{c}}$ & $\mathbf{P}^{\mathrm{d}}$ & PONTUAÇÃO ${ }^{\mathrm{e}}$ & INTENSIDADE $^{\mathrm{f}}$ \\
\hline Incêndios & 3 & 3 & 3 & 27 & SEVERO \\
\hline Desenvolvimento urbano & 3 & 3 & 2 & 18 & \multirow{2}{*}{ ALTO } \\
\hline Espécies exóticas invasoras & 3 & 3 & 2 & 18 & \\
\hline Disposição de resíduos & 1 & 3 & 2 & 6 & \multirow{3}{*}{ MODERADO } \\
\hline Atividades religiosas & 1 & 3 & 2 & 6 & \\
\hline Rodovia & 1 & 2 & 2 & 4 & \\
\hline Conflitos entre humanos e animais selvagens & 2 & 1 & 1 & 2 & \multirow{4}{*}{ LEVE } \\
\hline Crimes & 1 & 1 & 1 & 1 & \\
\hline Poluição sonora & 1 & 1 & 1 & 1 & \\
\hline Poluição hídrica & 1 & 1 & 1 & 1 & \\
\hline
\end{tabular}

\begin{tabular}{|c|c|c|c|c|c|}
\hline AMEAÇAS ${ }^{g}$ & $\mathbf{A}$ & $\mathbf{I}$ & $\mathbf{P}$ & PONTUAÇÃO & INTENSIDADE \\
\hline Incêndios & 3 & 3 & 3 & 27 & \multirow{2}{*}{ SEVERO } \\
\hline Desenvolvimento urbano & 3 & 3 & 3 & 27 & \\
\hline Espécies exóticas invasoras & 3 & 3 & 2 & 18 & \multirow{3}{*}{ ALTO } \\
\hline Disposição de resíduos & 2 & 3 & 2 & 12 & \\
\hline Poluição atmosférica & 2 & 2 & 3 & 12 & \\
\hline Poluição visual & 2 & 2 & 2 & 8 & \multirow{5}{*}{ MODERADO } \\
\hline Atividades religiosas & 1 & 3 & 2 & 6 & \\
\hline Rodovia & 1 & 3 & 2 & 6 & \\
\hline Crimes & 2 & 2 & 1 & 4 & \\
\hline Poluição sonora & 2 & 2 & 1 & 4 & \\
\hline $\begin{array}{l}\text { Conflitos entre humanos e animais } \\
\text { selvagens }\end{array}$ & 2 & 1 & 1 & 2 & \multirow{3}{*}{ LEVE } \\
\hline Poluição hídrica & 1 & 1 & 1 & 1 & \\
\hline Linhas de transmissão de energia & 1 & 1 & 1 & 1 & \\
\hline
\end{tabular}

a Pressões são processos, ações ou eventos, que já tiveram um impacto prejudicial sobre a integridade da UC (ERVIN, 2003).

b Abrangência: âmbito no qual o impacto de uma atividade ocorre, o qual pode ser medido em número, volume, área, etc. (ERVIN, 2003).

c Impacto: grau em que a pressão afeta direta ou indiretamente os recursos da unidade de conservação (ERVIN, 2003).

d Permanência: período de tempo necessário para os recursos da unidade de conservação se recuperarem das pressões, sem ou com a intervenção antrópica; resiliência (ERVIN, 2003).

e Pontuação é o produto da multiplicação dos três elementos (abrangência, impacto e permanência), que varia entre 1 e 64 (ERVIN, 2003)

${ }^{\mathrm{f}}$ Intensidade são os valores das pressões e ameaças, os quais poderão variar entre 01 e 64 , sendo considerados leves se ficarem compreendidos entre 01 e 03 , moderados entre 04 e 09 , altos entre

10 e 24 e severos entre 25 e 64 (ERVIN, 2003).

${ }^{\mathrm{g}}$ Ameaças são processos, atividades ou eventos potenciais pelos quais um impacto prejudicial provavelmente ocorrerá ou continuará no futuro (ERVIN, 2003). 
Apêndice VI. Matriz síntese da avaliação das pressões e ameaças da Estação Ecológica de Assis (EEcA).

\begin{tabular}{lccccc}
\hline \multicolumn{1}{c}{ PRESSÕES $^{\mathrm{a}}$} & $\mathbf{A}^{\mathrm{b}}$ & $\mathbf{I}^{\mathrm{c}}$ & $\mathbf{P}^{\mathrm{d}}$ & PONTUAÇÃO $^{\mathrm{e}}$ & INTENSIDADE $^{\mathrm{f}}$ \\
\hline Caça ilegal & 3 & 2 & 3 & 18 & \multirow{2}{*}{ ALTO } \\
\hline Disposição de resíduos & 1 & 3 & 4 & 12 & \multirow{2}{*}{ MODERADO } \\
\hline Expansão agrícola & 2 & 2 & 3 & 12 & \\
\hline Desenvolvimento urbano & 1 & 2 & 2 & 4 & \\
\hline Estradas e rodovias & 1 & 2 & 2 & 4 \\
\hline Crimes & 2 & 2 & 1 & 4 \\
\hline Conflitos entre humanos e animais selvagens & 1 & 3 & 1 & 3 \\
\hline Espécies exóticas invasoras & 1 & 1 & 2 & 2 \\
\hline Linhas de transmissão de energia & 1 & 1 & 2 & 2 \\
\hline Ocupações ilegais & 1 & 2 & 1 & 2 \\
\hline Poluição sonora & 1 & 2 & 1 & 2 \\
\hline Poluição visual & 1 & 1 & 2 & 2 \\
\hline Incêndios & 1 & 1 & 2 & 2 & \\
\hline
\end{tabular}

\begin{tabular}{|c|c|c|c|c|c|}
\hline AMEAÇAS ${ }^{g}$ & $\mathbf{A}$ & $\mathbf{I}$ & $\mathbf{P}$ & PONTUAÇÃO & INTENSIDADE \\
\hline Disposição de resíduos & 2 & 3 & 4 & 24 & SEVERO \\
\hline Caça ilegal & 3 & 2 & 3 & 18 & \multirow{3}{*}{ ALTO } \\
\hline Expansão agrícola & 2 & 3 & 3 & 18 & \\
\hline Desenvolvimento urbano & 2 & 3 & 2 & 12 & \\
\hline Estradas e rodovias & 1 & 3 & 3 & 9 & \multirow{8}{*}{ MODERADO } \\
\hline Espécies exóticas invasoras & 2 & 2 & 2 & 8 & \\
\hline Linhas de transmissão de energia & 2 & 2 & 2 & 8 & \\
\hline Crimes & 2 & 3 & 1 & 6 & \\
\hline $\begin{array}{l}\text { Conflitos entre humanos e animais } \\
\text { selvagens }\end{array}$ & 2 & 3 & 1 & 6 & \\
\hline Ocupações ilegais & 2 & 3 & 1 & 6 & \\
\hline Poluição sonora & 1 & 3 & 2 & 6 & \\
\hline Poluição visual & 1 & 2 & 2 & 4 & \\
\hline Poluição atmosférica & 1 & 1 & 3 & 3 & \multirow{2}{*}{ LEVE } \\
\hline Incêndios & 1 & 1 & 2 & 2 & \\
\hline
\end{tabular}

a Pressões são processos, ações ou eventos, que já tiveram um impacto prejudicial sobre a integridade da UC (ERVIN, 2003).

${ }^{\mathrm{b}}$ Abrangência: âmbito no qual o impacto de uma atividade ocorre, o qual pode ser medido em número, volume, área, etc. (ERVIN, 2003).

c Impacto: grau em que a pressão afeta direta ou indiretamente os recursos da unidade de conservação (ERVIN, 2003).

d Permanência: período de tempo necessário para os recursos da unidade de conservação se recuperarem das pressões, sem ou com a intervenção antrópica; resiliência (ERVIN, 2003).

e Pontuação é o produto da multiplicação dos três elementos (abrangência, impacto e permanência), que varia entre 1 e 64 (ERVIN, 2003 ).

${ }^{\mathrm{f}}$ Intensidade são os valores das pressões e ameaças, os quais poderão variar entre 01 e 64 , sendo considerados leves se ficarem compreendidos entre 01 e 03 , moderados entre 04 e 09 , altos entre

10 e 24 e severos entre 25 e 64 (ERVIN, 2003).

${ }^{\mathrm{g}}$ Ameaças são processos, atividades ou eventos potenciais pelos quais um impacto prejudicial provavelmente ocorrerá ou continuará no futuro (ERVIN, 2003). 
Apêndice VII. Matriz síntese da avaliação das pressões e ameaças do Sítio Natura 2000 Lendspitz-Maiernigg (LM).

\begin{tabular}{|c|c|c|c|c|c|}
\hline PRESSÕES ${ }^{\mathrm{a}}$ & $\mathbf{A}^{\mathrm{b}}$ & $\mathbf{I}^{\mathrm{c}}$ & $\mathbf{P}^{\mathrm{d}}$ & PONTUAÇÃO $^{\mathrm{e}}$ & INTENSIDADE $^{\mathrm{f}}$ \\
\hline Caça & 3 & 3 & 3 & 27 & \multirow{4}{*}{ SEVERO } \\
\hline Desenvolvimento urbano & 3 & 3 & 3 & 27 & \\
\hline Espécies exóticas invasoras & 3 & 3 & 3 & 27 & \\
\hline Turismo e recreação & 4 & 3 & 2 & 24 & \\
\hline Mudanças climáticas & 3 & 2 & 3 & 18 & \multirow{4}{*}{ ALTO } \\
\hline Pesca & 2 & 3 & 3 & 18 & \\
\hline Disposição irregular de resíduos & 2 & 2 & 3 & 12 & \\
\hline Estradas e Rodovia & 2 & 3 & 2 & 12 & \\
\hline Conflitos entre humanos e animais selvagens & 2 & 2 & 2 & 8 & \multirow{3}{*}{ MODERADO } \\
\hline Poluição sonora & 3 & 2 & 1 & 6 & \\
\hline Poluição visual & 3 & 2 & 1 & 6 & \\
\hline Crimes & 1 & 1 & 1 & 1 & LEVE \\
\hline
\end{tabular}

\begin{tabular}{|c|c|c|c|c|c|}
\hline AMEAÇAS & $\mathbf{A}$ & I & $\mathbf{P}$ & PONTUAÇÃO & INTENSIDADE \\
\hline Desenvolvimento urbano & 3 & 4 & 3 & 36 & \multirow{4}{*}{ SEVERO } \\
\hline Turismo e recreação & 4 & 4 & 2 & 32 & \\
\hline Caça & 3 & 3 & 3 & 27 & \\
\hline Mudanças climáticas & 3 & 3 & 3 & 27 & \\
\hline Espécies exóticas invasoras & 3 & 2 & 3 & 18 & \multirow{4}{*}{ ALTO } \\
\hline Estradas e Rodovia & 2 & 3 & 3 & 18 & \\
\hline Pesca & 2 & 3 & 3 & 18 & \\
\hline Poluição atmosférica & 3 & 2 & 3 & 18 & \\
\hline Poluição sonora & 3 & 3 & 1 & 9 & \multirow{4}{*}{ MODERADO } \\
\hline Poluição visual & 3 & 3 & 1 & 9 & \\
\hline Conflitos entre humanos e animais selvagens & 2 & 2 & 2 & 8 & \\
\hline Disposição irregular de resíduos & 2 & 1 & 3 & 6 & \\
\hline Crimes & 1 & 1 & 1 & 1 & LEVE \\
\hline
\end{tabular}

a Pressões são processos, ações ou eventos, que já tiveram um impacto prejudicial sobre a integridade da UC (ERVIN, 2003).

${ }^{b}$ Abrangência: âmbito no qual o impacto de uma atividade ocorre, o qual pode ser medido em número, volume, área, etc. (ERVIN, 2003).

c Impacto: grau em que a pressão afeta direta ou indiretamente os recursos da unidade de conservação (ERVIN, 2003).

d Permanência: período de tempo necessário para os recursos da unidade de conservação se recuperarem das pressões, sem ou com a intervenção antrópica; resiliência (ERVIN, 2003).

e Pontuação é o produto da multiplicação dos três elementos (abrangência, impacto e permanência), que varia entre 1 e 64 (ERVIN, 2003).

${ }^{\mathrm{f}}$ Intensidade são os valores das pressões e ameaças, os quais poderão variar entre 01 e 64 , sendo considerados leves se ficarem compreendidos entre 01 e 03 , moderados entre 04 e 09 , altos entre

10 e 24 e severos entre 25 e 64 (ERVIN, 2003).

g Ameaças são processos, atividades ou eventos potenciais pelos quais um impacto prejudicial provavelmente ocorrerá ou continuará no futuro (ERVIN, 2003). 
Apêndice VIII. Matriz síntese da avaliação das pressões e ameaças do Sítio Natura 2000 Sonian Forest (SF).

\begin{tabular}{|c|c|c|c|c|c|}
\hline PRESSÕES ${ }^{\mathrm{a}}$ & $\mathbf{A}^{\mathrm{b}}$ & $\mathbf{I}^{\mathrm{c}}$ & $\mathbf{P}^{\mathrm{d}}$ & PONTUAÇÃ̃ $^{\mathrm{e}}$ & INTENSIDADE $^{\mathrm{f}}$ \\
\hline Desenvolvimento urbano & 3 & 3 & 3 & 27 & \multirow{2}{*}{ SEVERO } \\
\hline Turismo e recreação & 4 & 3 & 2 & 24 & \\
\hline Espécies exóticas invasoras & 3 & 2 & 3 & 18 & \multirow{6}{*}{ ALTO } \\
\hline Estradas, rodovias e ferrovias & 2 & 3 & 3 & 18 & \\
\hline Poluição atmosférica & 3 & 3 & 2 & 18 & \\
\hline Poluição hídrica & 2 & 3 & 2 & 12 & \\
\hline Poluição sonora & 3 & 2 & 2 & 12 & \\
\hline Poluição visual & 3 & 2 & 2 & 12 & \\
\hline Conflitos entre humanos e animais selvagens & 2 & 2 & 2 & 8 & MODERADO \\
\hline Crimes & 1 & 1 & 1 & 1 & \multirow{2}{*}{ LEVE } \\
\hline Disposição de resíduos & 1 & 1 & 1 & 1 & \\
\hline
\end{tabular}

\begin{tabular}{|c|c|c|c|c|c|}
\hline AMEAÇAS & $\mathbf{A}$ & $\mathbf{I}$ & $\mathbf{P}$ & PONTUAÇÃO & INTENSIDADE \\
\hline Desenvolvimento urbano & 3 & 4 & 3 & 36 & \multirow{2}{*}{ SEVERO } \\
\hline Poluição atmosférica & 3 & 3 & 3 & 27 & \\
\hline Estradas, rodovias e ferrovias & 2 & 4 & 3 & 24 & \multirow{7}{*}{ ALTO } \\
\hline Turismo e recreação & 4 & 3 & 2 & 24 & \\
\hline Espécies exóticas invasoras & 3 & 2 & 3 & 18 & \\
\hline Mudanças climáticas & 3 & 2 & 3 & 18 & \\
\hline Poluição sonora & 3 & 3 & 2 & 18 & \\
\hline Poluição visual & 3 & 3 & 2 & 18 & \\
\hline Poluição hídrica & 2 & 3 & 2 & 12 & \\
\hline Conflitos entre humanos e animais selvagens & 2 & 2 & 1 & 4 & MODERADO \\
\hline Disposição de resíduos & 1 & 2 & 1 & 2 & \multirow{2}{*}{ LEVE } \\
\hline Crimes & 1 & 1 & 1 & 1 & \\
\hline
\end{tabular}

a Pressões são processos, ações ou eventos, que já tiveram um impacto prejudicial sobre a integridade da UC (ERVIN, 2003).

${ }^{b}$ Abrangência: âmbito no qual o impacto de uma atividade ocorre, o qual pode ser medido em número, volume, área, etc. (ERVIN, 2003).

c Impacto: grau em que a pressão afeta direta ou indiretamente os recursos da unidade de conservação (ERVIN, 2003).

d Permanência: período de tempo necessário para os recursos da unidade de conservação se recuperarem das pressões, sem ou com a intervenção antrópica; resiliência (ERVIN, 2003).

${ }^{\text {e }}$ Pontuação é o produto da multiplicação dos três elementos (abrangência, impacto e permanência), que varia entre 1 e 64 (ERVIN, 2003).

${ }^{\mathrm{f}}$ Intensidade são os valores das pressões e ameaças, os quais poderão variar entre 01 e 64 , sendo considerados leves se ficarem compreendidos entre 01 e 03 , moderados entre 04 e 09 , altos entre 10 e 24 e severos entre 25 e 64 (ERVIN, 2003).

${ }_{\mathrm{g}}^{\mathrm{g}}$ Ameaças são processos, atividades ou eventos potenciais pelos quais um impacto prejudicial provavelmente ocorrerá ou continuará no futuro (ERVIN, 2003). 
Apêndice XIX. Matriz síntese da avaliação das pressões e ameaças do Sítio Natura 2000 e Parque Nacional Zuid-Kennemerland (PNZK).

\begin{tabular}{|c|c|c|c|c|c|}
\hline PRESSÕES ${ }^{\mathrm{a}}$ & $\mathbf{A}^{\mathrm{b}}$ & $\mathbf{I}^{\mathrm{c}}$ & $\mathbf{P}^{\mathrm{d}}$ & PONTUAÇÃO ${ }^{\mathrm{e}}$ & INTENSIDADE $^{\mathrm{f}}$ \\
\hline Espécies exóticas invasoras & 4 & 3 & 3 & 36 & \multirow{2}{*}{ SEVERO } \\
\hline Poluição atmosférica & 4 & 3 & 3 & 36 & \\
\hline Desenvolvimento urbano & 4 & 2 & 3 & 24 & \multirow{4}{*}{ ALTO } \\
\hline Transmissão de doenças & 4 & 3 & 2 & 24 & \\
\hline Turismo e recreação & 3 & 2 & 3 & 18 & \\
\hline Estradas, rodovias e ferrovias & 2 & 2 & 3 & 12 & \\
\hline Conflitos entre humanos e animais selvagens & 3 & 2 & 1 & 6 & \multirow{5}{*}{ MODERADO } \\
\hline Mudanças climáticas & 2 & 1 & 3 & 6 & \\
\hline Atividades industriais & 1 & 2 & 2 & 4 & \\
\hline Poluição sonora & 4 & 1 & 1 & 4 & \\
\hline Poluição visual & 4 & 1 & 1 & 4 & \\
\hline Disposição irregular de resíduos & 1 & 1 & 1 & 1 & \multirow{2}{*}{ LEVE } \\
\hline Extração de produtos não madeireiros & 1 & 1 & 1 & 1 & \\
\hline
\end{tabular}

\begin{tabular}{llllll}
\hline \multicolumn{1}{c}{ AMEAÇAS } & A & I & P & PONTUAÇÃO & INTENSIDADE \\
\hline Espécies exóticas invasoras & 4 & 4 & 3 & 48 & \multirow{2}{*}{ SEVERO } \\
\cline { 1 - 4 } Poluição atmosférica & 4 & 4 & 3 & 48 & \\
\hline Desenvolvimento urbano & 4 & 3 & 3 & 36 & \multirow{2}{*}{ ALTO } \\
\hline Transmissão de doenças & 4 & 3 & 2 & 24 & \\
\hline Estradas, rodovias e ferrovias & 2 & 3 & 3 & 18 & \multirow{2}{*}{ MODERADO } \\
\hline Turismo e recreação & 2 & 2 & 3 & 12 & \\
\hline Mudanças climáticas & 3 & 1 & 3 & 9 & \multirow{2}{*}{ LEVE } \\
\hline Poluição sonora & 4 & 2 & 1 & 8 & \\
\hline Poluição visual & 4 & 2 & 1 & 8 & \\
\hline Conflitos entre humanos e animais selvagens & 3 & 1 & 1 & 3 & \\
\hline Atividades industriais & 1 & 1 & 2 & 2 & \\
\hline Disposição irregular de resíduos & 1 & 1 & 1 & 1 & \\
\hline Extração de produtos não madeireiros & 1 & 1 & 1 & 1 & \\
\hline
\end{tabular}

a Pressões são processos, ações ou eventos, que já tiveram um impacto prejudicial sobre a integridade da UC (ERVIN, 2003).

${ }^{b}$ Abrangência: âmbito no qual o impacto de uma atividade ocorre, o qual pode ser medido em número, volume, área, etc. (ERVIN, 2003).

c Impacto: grau em que a pressão afeta direta ou indiretamente os recursos da unidade de conservação (ERVIN, 2003).

${ }^{d}$ Permanência: período de tempo necessário para os recursos da unidade de conservação se recuperarem das pressões, sem ou com a intervenção antrópica; resiliência (ERVIN, 2003).

e Pontuação é o produto da multiplicação dos três elementos (abrangência, impacto e permanência), que varia entre 1 e 64 (ERVIN, 2003).

${ }_{\mathrm{f}}^{\mathrm{f}}$ Intensidade são os valores das pressões e ameaças, os quais poderão variar entre 01 e 64 , sendo considerados leves se ficarem compreendidos entre 01 e 03 , moderados entre 04 e 09 ,

altos entre 10 e 24 e severos entre 25 e 64 (ERVIN, 2003).

${ }^{\mathrm{g}}$ Ameaças são processos, atividades ou eventos potenciais pelos quais um impacto prejudicial provavelmente ocorrerá ou continuará no futuro (ERVIN, 2003). 
Apêndice X. A. Vista para o município de São Paulo, registrada no Pico do Jaraguá (PEJ). B. Casarão do bandeirante Afonso Sardinha (PEJ). C. Pico do Jaraguá, ponto mais alto do município de São Paulo (PEJ). D. Morador do entorno captando água da bica, no interior do PEJ. Fontes: registros pessoais da autora (2016).

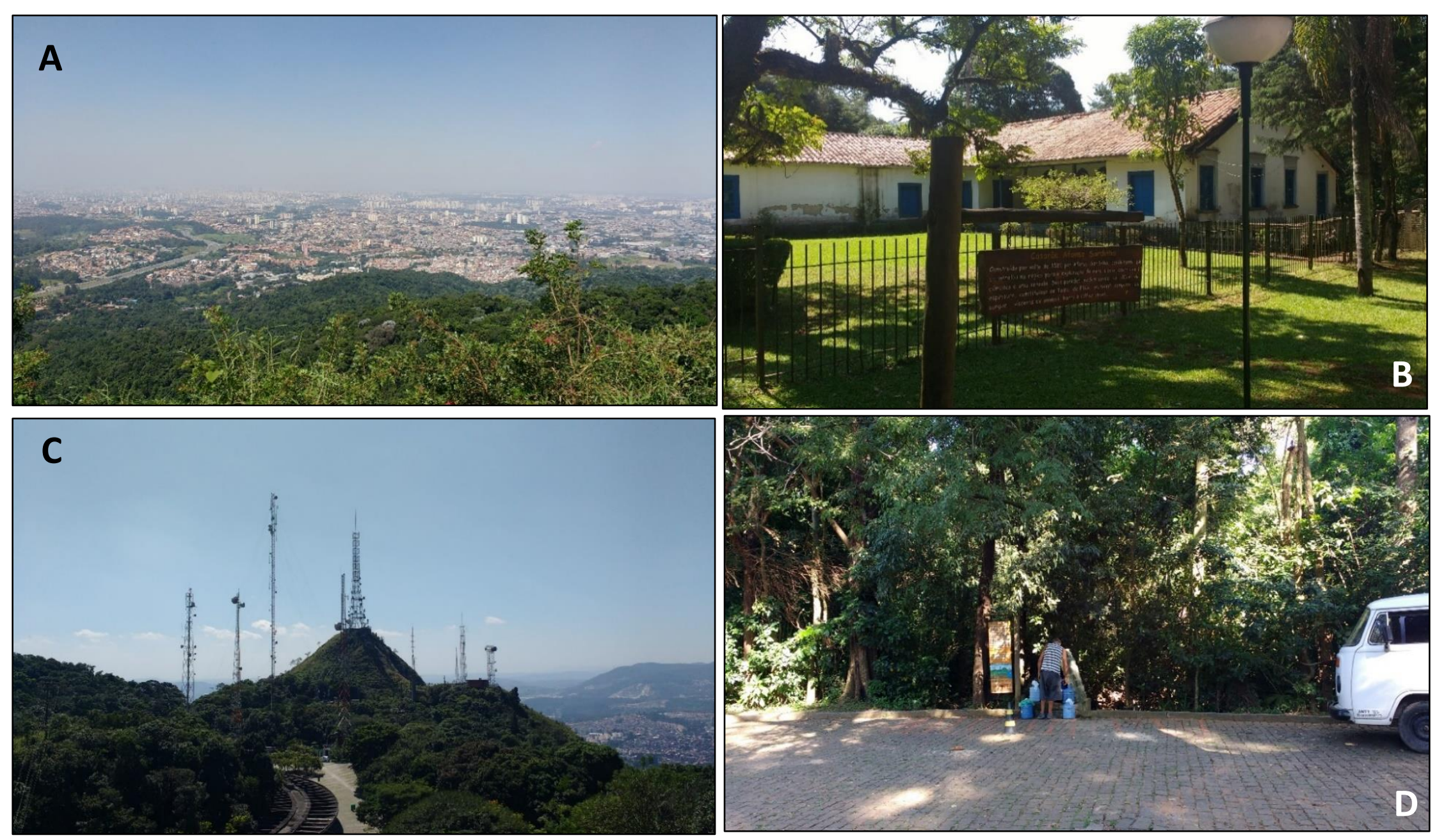


Apêndice XI. A e C. Placas sinalizadoras no interior do PEC. B e D. Vista da Pedra Grande (PEC). Fontes: registros pessoais da autora (2016).
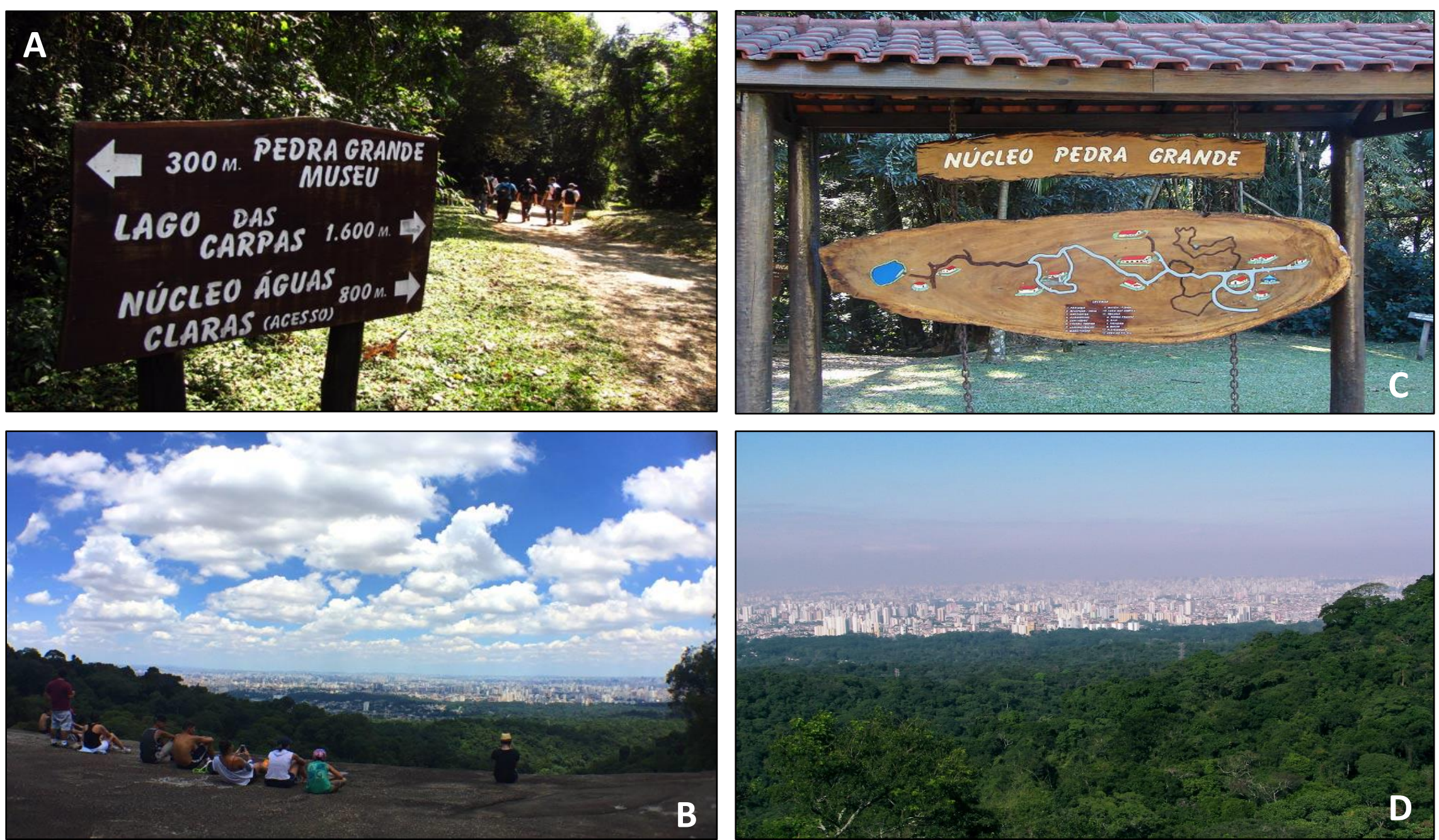
Apêndice XII. A. Estrada municipal Eugênio do Val que corta a EERP, atualmente fechada. Fonte: registros pessoais da autora (2016). B. Vista de obra ao lado da EERP. Fonte: SMMA, RARAM Loteamento Bosque Santa Tereza. C. Macaco-prego (primata) na EERP. Fonte: SMMA, RARAM Loteamento Bosque Santa Tereza. D. Visitante oferecendo comida aos macacos-prego. Fonte: SMMA, RARAM Loteamento Bosque Santa Tereza.
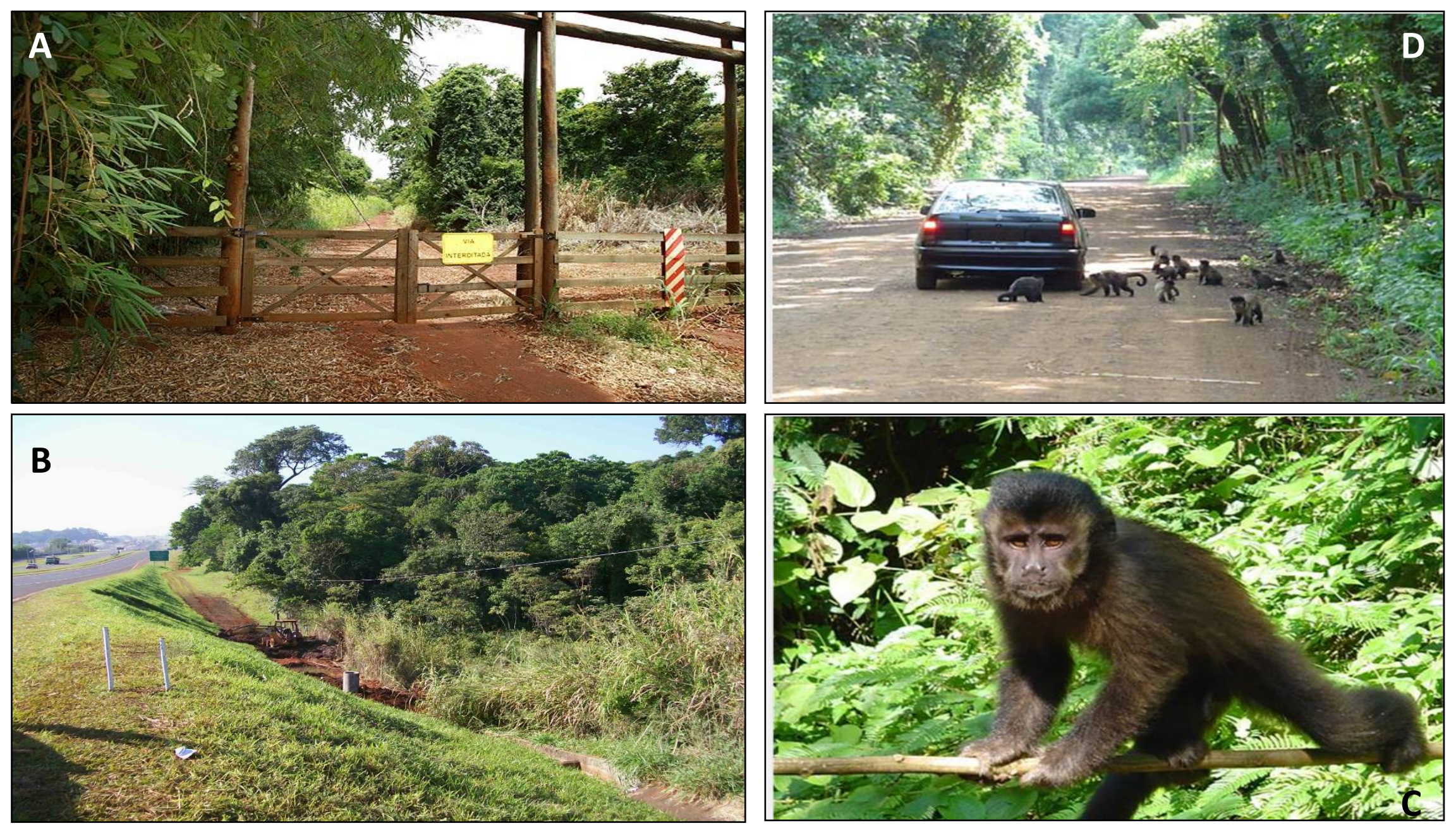
Apêndice XIII. A. Placa sinalizadora na EEcA. B. Grupo de alunos visitando a EEcA e a Flona de Assis. C. Mata ciliar na EEcA. D. Interior da EEcA. Fonte: Todas as fotos foram retiradas do Blog Amigos da Natureza ${ }^{114}$, período: 2012.
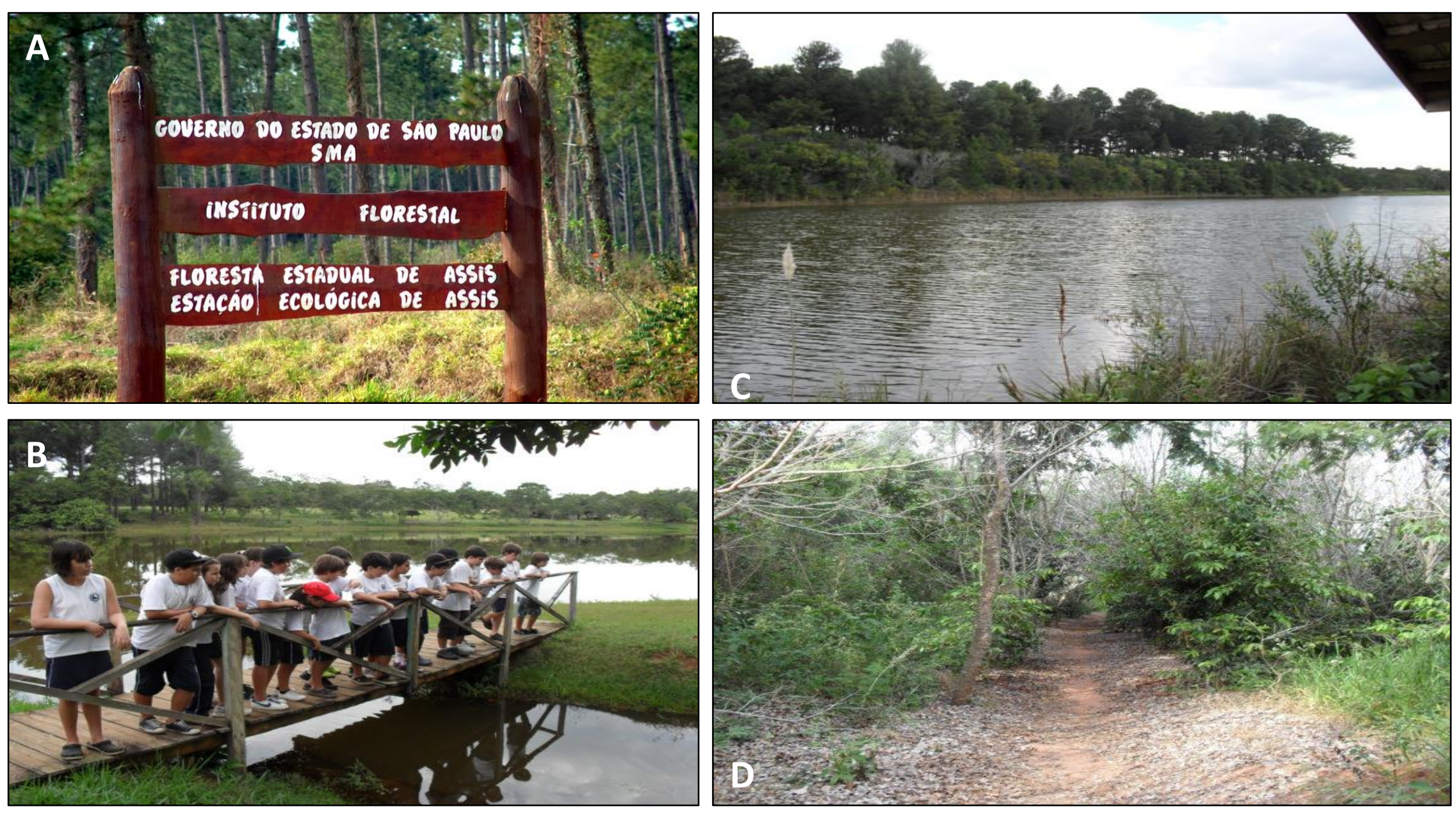

${ }^{114}$ Disponível em: < https://xeretaamigosdanatureza.wordpress.com/>. 
Apêndice XIV. A. Antigo acampamento no interior do Sítio Natura 2000 Lendspitz-Maiernigg (LM). Fonte: Hradetzky (2014). B. Jardim de residência adjacente ao sítio LM. Fonte: Hradetzky (2014). C. Local atual do antigo acampamento, após recuperação do local. Fonte: Hradetzky (2014). D. Lago no interior do sítio LM. E. Interior do sítio LM. Fonte: Arge Naturschutz ${ }^{115}$ (2016). F. Reunião Conselho sítio LM, período 2012. Fonte: KREIMER et al. (2013).

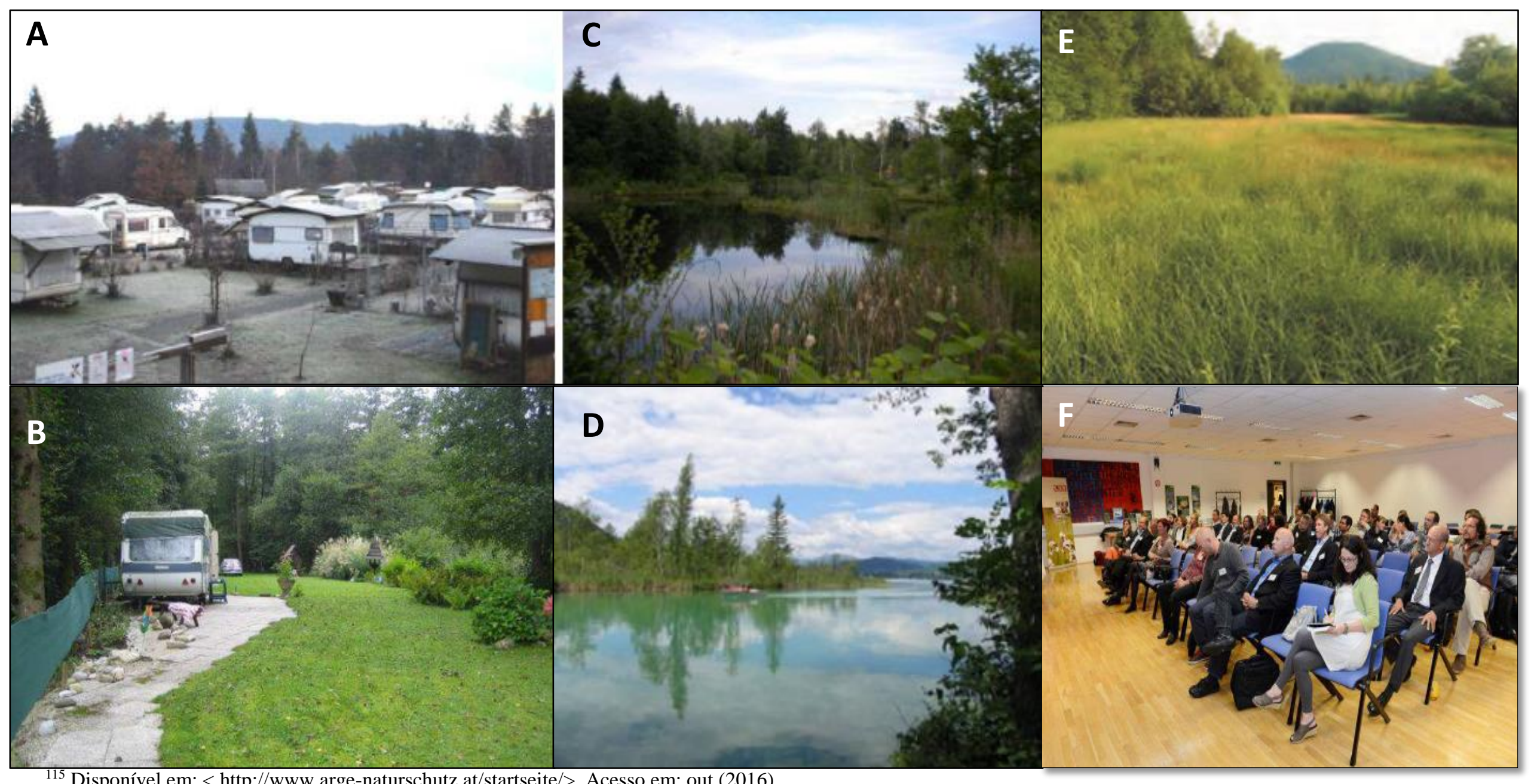

${ }^{115}$ Disponível em: < http://www.arge-naturschutz.at/startseite/>. Acesso em: out (2016). 
Apêndice XV. A. Floresta de faia-europeia (Sítio Natura 2000 Sonian Forest). B. Visitantes no sítio SF. C. Lagoas e bosques úmidos do sítio SF. D. Grupo de estudantes em visita guiada no sítio SF. Fonte: Sonian Forest ${ }^{116}$ (2016).
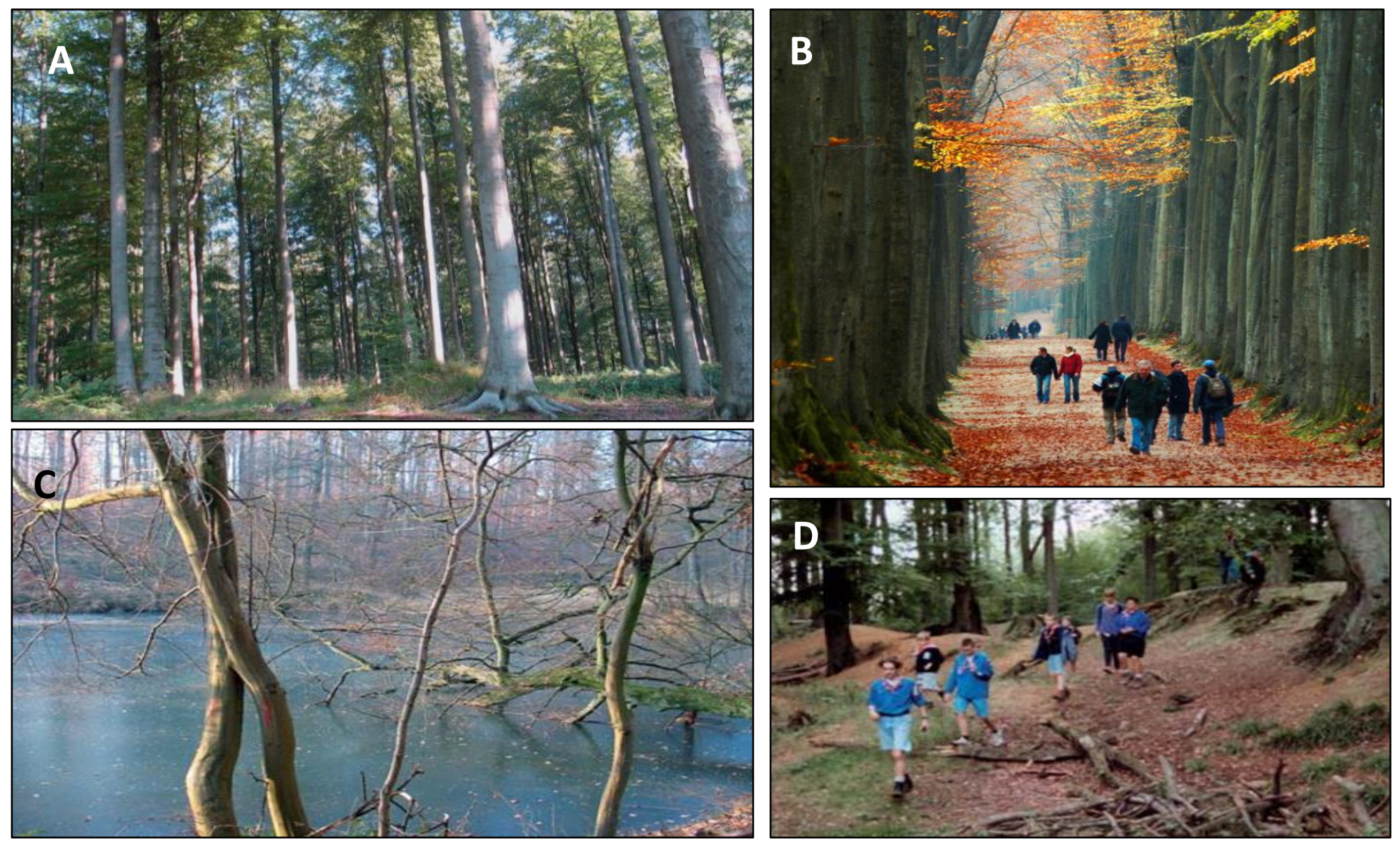

${ }^{116}$ Disponível em: < http://www.sonianforest.be/>. Acesso em: Out 2016. 
Apêndice XVI. A, B e C. Centro de visitantes do Sítio Natura 2000 e Parque Nacional Zuid-Kennemerland (PNZK). D. Lagoa no interior do PNZK. E. Estacionamento de bicicletas no interior do PNZK. F. Floresta no interior do PNZK. Fonte: registros pessoais da autora (2016).

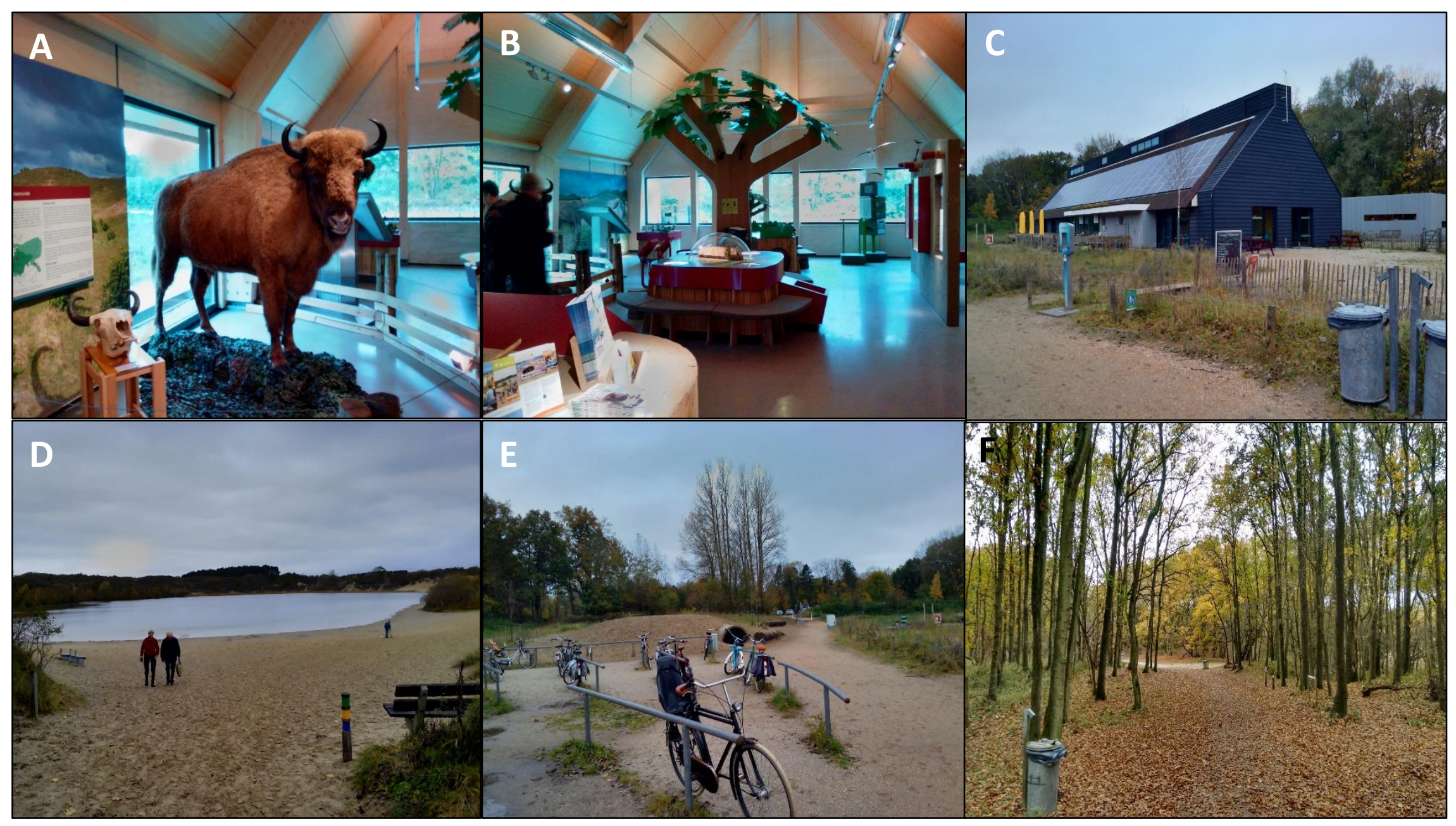

